\title{
Asphyxia during birth : biochemical and morphological study in basal ganglia : implication of hypothermia
}

Citation for published version (APA):

Loidl, C. F. (1997). Asphyxia during birth : biochemical and morphological study in basal ganglia : implication of hypothermia. [Doctoral Thesis, Maastricht University]. Universiteit Maastricht. https://doi.org/10.26481/dis.19970116cl

Document status and date:

Published: 01/01/1997

DOI:

10.26481/dis.19970116cl

Document Version:

Publisher's PDF, also known as Version of record

\section{Please check the document version of this publication:}

- A submitted manuscript is the version of the article upon submission and before peer-review. There can be important differences between the submitted version and the official published version of record. People interested in the research are advised to contact the author for the final version of the publication, or visit the DOI to the publisher's website.

- The final author version and the galley proof are versions of the publication after peer review.

- The final published version features the final layout of the paper including the volume, issue and page numbers.

Link to publication

\footnotetext{
General rights rights.

- You may freely distribute the URL identifying the publication in the public portal. please follow below link for the End User Agreement:

www.umlib.nl/taverne-license

Take down policy

If you believe that this document breaches copyright please contact us at:

repository@maastrichtuniversity.nl

providing details and we will investigate your claim.
}

Copyright and moral rights for the publications made accessible in the public portal are retained by the authors and/or other copyright owners and it is a condition of accessing publications that users recognise and abide by the legal requirements associated with these

- Users may download and print one copy of any publication from the public portal for the purpose of private study or research.

- You may not further distribute the material or use it for any profit-making activity or commercial gain

If the publication is distributed under the terms of Article 25fa of the Dutch Copyright Act, indicated by the "Taverne" license above, 


\section{ASPHYXIA DURING BIRTH:}

BIOCHEMICAL AND MORPHOLOGICAL STUDY IN BASAL GANGLIA. IMPLICATION OF HYPOTHERMIA.

\section{PROEFSCHRIFT}

ter verkrljging van de graad van doctor aan de Universiteit Maastricht op gezag van de Rector Magnificus, Prof.Mr. M.]. Cohen, volgens het besluit van het College van Decanen, in het openbaar te verdedigen op donderdag 16 januari 1997 om 16.00 uur door

César Fabián Loidl geboren op 12 januari 1963 te Buenos Aires, Argentiniē 


\section{Promotor:}

Prof. Dr. C.E. Blanco

\section{Beoordelingscommissie:}

Prof. Dr. ). Troost, voorzitter

Prof. Dr. P. Casaer (Katholieke Universiteit Leuven)

Prof. Dr. J. de Haan

Prof. Dr. P.G.M. Luiten (Rijksunlversiteit Groningen)

Dr. H.W.M. Steinbusch

Asphyxia during Birth: Biochemical and Morphological Study in Basal Ganglia. Implication of Hypothermia.

César Fabian Loldl.

Proefschrift Masstricht - Met lit. Opg. - Met samenvatting in het Nederlands.

Vormgeving: César Fablán Loidl

Omslagillustratie: Astronomisch Kunstuurwerk. Dit kunstwerk bevindt zich in de serrehal van het academisch ziekenhuis Mastricht 
To Nora, Emilia and Eugenia

and in memory of my dear friend Mario Gullé 



\section{ASPHYXIA DURING BIRTH}

Biochemical and morphological study on basal ganglia. Implication of hypothermia

\section{Contents}

Abbreviations

Chapter 1

Chapter 2

General introduction: review of the literature 6

2.1 Acute perinatal asphyxia 6

2.1.1 General introduction 6

2.1.2 Definidion of perinatal asphyxla In the cllnical practice 7

2.1.3 Brain and perinatal asphyxia 8

2.2 Brief description of basal ganglla anatomy 8

2.3 Possible neurotoxic mechanisms induced by asphyxla 11

2.3.1 Excessive excitatory aminoacids release 11

2.3.2 Free radicals production 13

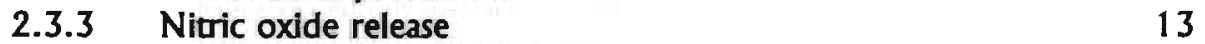

2.3.4 Lactic acid accumulation $\quad 14$

$\begin{array}{lll}2.3 .5 & \text { Role of calcium } & 15\end{array}$

2.3.6 Excessive release of neurotransmitters 15

$\begin{array}{lll}\text { 2.3.7 Membrane degradation } & 16\end{array}$

2.4 Asphyxia and intermediate filaments In neurons and glla 16 


\section{Chapter 3}

$3 \quad$ Material \& methods

3.1 Subjects

3.2 Surgical technique to induce perinatal asphyxia

3.3 Behavioural studles

3.4 Microdialysis technlque 20

3.4.1 Brief description 20

3.4.2 Subcutaneous mlcrodialysis in newbom rats 22

3.4.3 Intracerebral microdialysis. Study of the nigrostrlatal system 22

3.5 Possible therapeutic agents tested during experimental perinatal asphyxia

3.6 Cresyl violet histology

3.7 Immunocytochemistry

3.8 NADPH-diaphorase histochemical technique

3.9 Computerized Image analysis

3.10 Statstical analysis

Chapter 4

4.1 The experimental model. Protection from mortality in PA by Hypothermia

4.2 SHORT-TERM EFFECTS OF PERINATAL ASPHYXIA

4.2.1 Survival, behavlour and subcutaneous microdlalysis in asphyctic, controls and hypothermic-treated pups

a. Effects of dellvery through hysterectomy (caesarea) and normal vaginal delivery

b. Slight and moderate asphyctic exposure

c. Subsevere asphyctic exposure

d. Severe asphyctic exposure 
4.2.2 Effects of the antagonists of glutamate receptors

4.2.3 NADPH-d histochemical staining in asphyctic, control and hypothermic-treated pups

4.3 LONG-TERM EFFECTS OF PERINATAL ASPHYXIA

4.3.1 Intracerebral microdialysis

4.3.2 Immunocytochemistry and basal ganglia in asphyctic and control adult rats

4.3.3 NADPH-histochemical staining in ó months old asphyctic, control and hypothermic-treated adult rats

4.3.4 Cresyl violet staining in striatum and cerebral cortex

Chapter 5

$5 \quad$ General discussion

62

5.1 Utility of the model

5.2 Behavioural evaluation

62

5.3 Why are neonates more resistant to asphyxla?

5.4 Hypothermla and survival protection to asphyxla

5.5 Glutamate antagonists and perinatal asphyxla

5.6 Subcutaneous microdialysis. Indicator of long-term damage as a prognosis tool?

5.7 Do long-term dopaminergic changes represent a sign of accelerated ageing?

5.8 Asphyxla and reactive astrocytosis. GFAP immunostaining

5.9 Perinatal asphyxia and hypertrophy of NF. A sign of neurodegenerative and accelerated ageing?

5.10 Cytomegallc NOS-containing neurons assoclated with PA:

A sign of neuroprotection or neurotoxicity?

a. Acute changes In NOS after PA (newborn rats)

b. Chronic changes in NOS after PA (6-months old rats) 
Chapter 6

Chapter 7

7.1 Summary

7.2 Samenvatting

References

Publicatlons 


\section{ABBREVIATIONS}

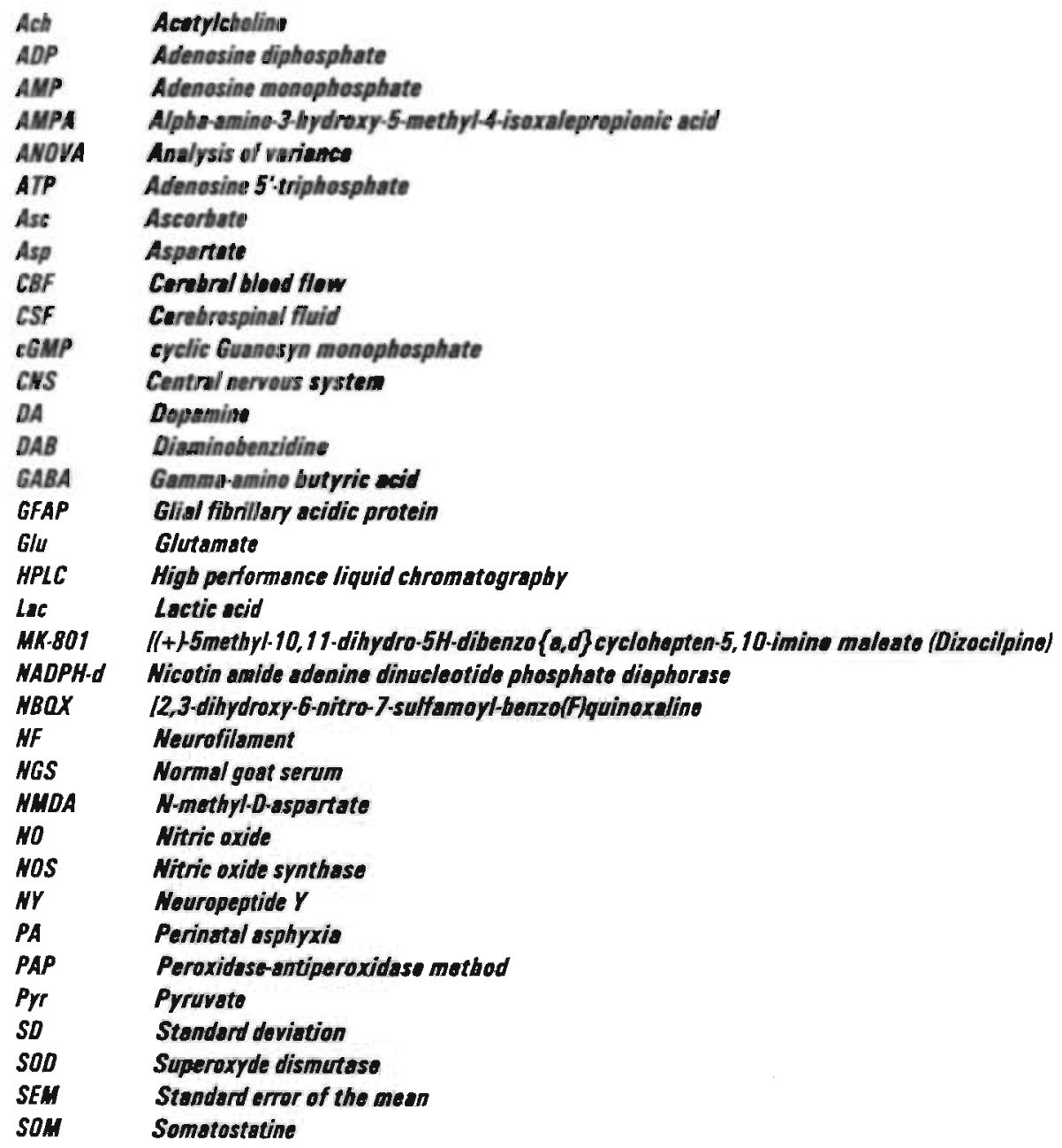


CHAPTER 1 


\section{PURPOSE OF RESEARCH}

Perlnatal asphyxia (PA) is a major worldwide problem In perinatology. Per year, 4 million Infants are affected by this problem, with 800.000 dying and another 800.000 suffering brain damage (WHO Report, 1991). PA is a serious problem in less developed countrles (Costello, 1994), where care and precautions are neither always available nor properly applled.

The aim of this thesis is focused on:

1. The development of an original experimental model in order to study short and long-term consequences produced by asphyxla during birth.

2. The study of new therapeutical approaches in order to control asphyctic damage.

3. A blochemlcal and morphological study of basal ganglia In rats exposed to PA, using mlcrodialisys, histochemistry and Immunocytochemistry respectively. 
CHAPTER 2 


\section{GENERAL INTRODUCTION: REVIEW OF THE LITERATURE}

The normal growth and development of a fetus depends on a normal interchange of gases, nutrients and metabolic waste with the placenta. If an abnormality produces a breakdown In these homeostatic mechanisms, then a rapid or slow Insufficiency in the fetal requirements develops, leading to an acute, subacute or chronic asphyxia.

\subsection{ACUTE PERINATAL ASPHYXIA}

2.1.1 General Introduction: Acute PA is the principal cause of death and neurological Injury In newborn Infants. The incldence of this problem has been estimated at 2-4 cases per each 1000 births at term, and this percentage has not decreased desplte widespread medical advances in perinatal and obstetric care (HIII, 1991; Younkln, 1992). Most asphyctic Infants die during the perinatal period and $20-30 \%$ of survlvals present short or long-term evident sequelae, amongst whlch hyperactivity and attention deficlt disorders (DSM III R, American Psychlatric Assoclation), epilepsy, motor disorders, mental retardation and cerebral palsy or spastlclty are included (Volpe, 1987; Younkin, 1992).

The word asphyxia derlves from the words $a$, whlch means lack or $a b$ sence and sphyzo, whlch means palpitation or heart movements. Also, it is used to describe a lack of body movement, specifically, those that refer to breathing (Bonnet, 1982). Asphyxla is a state of hypoxia and Ischemia that If sustalned can lead to death.

Hypoxia is a decrease In oxygen supply and ischemia is a decrease in blood supply to the tlssues (Percy, 1986; Volpe, 1987).

Most cases of PA remaln unexplained, but amongst the multiple aetiologies known to induce lack of oxygen the most common are: cord compression, true knot in cord, abruptio placenta, placenta previa, infarct of the placenta, haemonhage or anemla of the mother, toxaemia and obstetric complications durlng dellvery.

The comblnation of hypoxia and ischemia is called hypoxia-ischemia. If an organlsm is subjected to this state for a certain period of time, cells trigger selfdefense mechanisms that lead to a degeneration, If the lack of oxygen persists. Some tissues suffer the harmful effects of a diminished blood flow and a reduced avallabillty of oxygen and glucose more than others - the mammallan brain is an example of the rapldity with which a state of cerebral hypoxia-ischemia causes damage.

The main cause for cerebral hypoxla during PA is ischemia and in $90 \%$ of the cases thls occurs during ante-and/or -intra partum. Asphyctic babies suffer a global decrease - or interruption - In oxygenation that in severe cases although also affecting other organs, mainly leads to neurological Injuries. 
According to its severity, cerebral hypoxia-lschemla can be divided in two categories: focal and global. Focal ischemia occurs when a specific region of the brain is affected, e.g. an occlusion or vascular intermuption such as an acute thrombotic or embolic stroke. Its neuropathology is characterized by a pannecrosis or infarction, where all cell types are affected - and this is well evident: after 6 hours. If a decrease in cerebral blood flow (CBF) below $15-20 \%$ is sustained for 3-4 hours, then infarction of the tissue occurs. The severity of the damage depends on where the occlusion of the vessel occurs. The damage produced by an infarct has two zones: core, place of irreversible injury, and penumbra, the place of electrical and functional quiescence. Therefore, achleving reperfusion is extremely Important (Ginsberg, 1995). Global ischemia occurs when all blood supply to the brain is interrupted, as in a cardlac arrest with resuscitation. A lowering in CBF towards zero, lasting at least 5-10 minutes, leads to abnormalities. In this case, there is a general involvernent, but damage occurs mainly in the so-called "vulnerable" areas of the brain: hippocampus, striatum, cerebral cortex and cerebellum (Ginsberg, 1995). SInce after an acute global oxygen arrest, the injury suffered by neurons continues to develop for hours - or even days - the possibility of using treatment to stop damage from expanding is potentially present (Petto, 1987; Garcia, 1992). PA is a type of global hypoxia-ischemia, since all oxygen supply to the feus is temporarlly interrupted.

A severe state of hypoxia-ischemla depresses the respiratory centers, leading to anoxemia. In anoxia-ischemla, a lack of oxygen and nutrients added to an accumulation of metabolic products lead through different mechanisms to cell death if the problem is not rapidly solved (Cervós-Navarro, 1991).

\subsubsection{Definition of Perinatal Asphyxia in the Clinical Practice:}

Unfortunately, different medical specialisms define PA in different ways. To the obstetricians, the appearance of meconium, fetal heart rate alterations and acidosis signals asphyxia; to the neonatologists, it is a low Apgar score, a delay in the establishing of breathing accompanied by signs of behavioural alterations or encephalopathy that slgnals it. The most widely accepted clinical PA definition Includes the following parameters: acidosis, a low Apgar score after blrth, delay in breathing and a need for an active resuscitation (Hull \& Dodd, 1991).

A major clinical problem is that when PA is not severe, neither mother nor infant present any sign or symptom; the infant's problem will become evident only in the long-term. At present, If PA is suspected, help through computerized tomography can be extremely useful to detect damage, showing hemorrhagic and low density areas in the brain - simllar to typical infarct images. Also, an electroencephalographic study can help define the presence - or absence - of eplleptic form activity. 
In PA, prognosis is extremely difficult to establish: one same Apgar score lower than 3 at 10 minutes may lead one third of the cases to severe neurological sequelae whereas another third will be normal. If hypotonia - a sign that accompanies severe PA with a low Apgar score - disappears within a few hours then, usually, the infant will not have neurological sequelae. However, if within 24 hours hypotonia rapidly progresses to hypertonia, they will. (Percy, 1986). Also, cerebral creatin quinase isoenzyme in blood is measured and sudied in order to assess neurological outcome sequelae In term infants (Walsh, 1982)

Evidently, the best solution to PA lies in its prevention. At present, new pharmacological approaches such as calclum blockers, glutamate antagonists, antagonism of oxygen free radlcals, corticosterolds and others are being tried out on animals and promise to be useful for humans in the future.

2.1.3 Brain and perinatal asphyxia: A deficit of oxygen supply affects the carbohydrate metabolism and therefore, the energy supply: this is the first alteration produced on the tissues by asphyxia. The central nervous system (CNS) is highly vulnerable to lack of oxygen due to (1) its need for great amounts of energy in order to maintain Its ionic cell homeostasis and (2) to the fact that its available sustrate storage for the anaeroblc metabolism is low (Hansen, 1985; Erecinska, 1989; Slesjō, 1988).

Numerous studles show that hypoxia does not affect all areas of the brain in one same way. The most vulnerable neurons are those in the following areas: (i) CA1, CA3 and CA 4 of the hippocampus, with pyramidal cells in CA 1 being the most vulnerable to global Ischemla in both humans and animals, (ii) small-to-medlum neurons of the basal ganglla, In particular those in the caudateputamen nuclel, (III) Purklnje cells In the cerebellum and (Iv) neurons of layers 3, 5 and 6 in the cerebral cortex. The mechanisms responsible for making these areas more vulnerable than others are still unclear (Pasternak, 1991; Paschen, 1989; Cervós-Navarro, 1991, Ginsberg, 1995).

\subsection{BRIEF DESCRIPTION OF BASAL GANGLIA ANATOMY}

The basal ganglla is a complex neuronal net that transports and connects signals emltted by the cerebral cortex. In terms of structure, the basal ganglia is formed by a deep and voluminous nuclei on each side of the cerebral hemispheres (striatum, formed by the caudate-putamen and pallidum). In terms of function, this group of nuclei acts in connection with other mesencephalic nuclel (substantia nigrta and subthalamic nuclei). There is a great diversity of neurotransmitters and neuromodulators in these cerebral pathways. Their functions include memory aspects, programmation, selection and execution of motor movernents. 
In the striatum, dopamine (DA) terminals - mostly originating In substantla nigra neurons - are directly linked with medium-sized spiny neurons that utlize gamma-amino butyric acid (GABA) as principal neurotransmitter. The striatum also has intrinsic large-sized neurons containing acetylcholine (Ach) (Bolam, 1984). It has been suggested that stratal cholinergic neurons are not synaptically linked with DA terminals (Lehmann, 1983). However, electron microscopy studies provided evidence that striatal Ach neurons may indeed recelve direct inputs from dopaminergic axons (Kubota, 1987), and in situ hybrldization studles have demonstrated that $95 \%$ of large-sized neurons in the striatum express mRNA for DA D-2 receptors (Brené, 1990). The medium-sized spiny neurons emit axons both to the globus pallidus and the substantia nigra. Neurons emitting to the globus pallidus contain both GABA and enkephalin whereas striato-nlgral fibers contain GABA, substance $P$ and dynorphin (Grayblel, 1990). Adding a description of different types of dopamine receptors, e.g. DA acts on striato-palldal neurons via D-2 type of receptors and on striato-nigral neurons vla D-1 receptors, the net becomes even more complex (Gerfen, 1990). On the other hand, there is evidence that striatal DA release is presynaptically modulated by glutamatergic cortical inputs. It has been suggested that DA stimulation produced by glutamate reflects the direct axonal interactlons between glutarnatergic and dopaminergic terminals in the striatum.

Furthermore, the striatum contains the highest cerebral activity of cGMP and soluble guanylate cyclase, which is the target of nitric oxide (NO). The histo chemical technique for NADPH-d and immunocytochemical technlque for NO synthase (NOS) have revealed the presence of medium-sized non-spinal NOScontaining interneurons, which are the same contalned by somatostatne (SOM) and neuropeptide $Y$ (NY). Not only NOS but also CGMP appear to be absent in the giant cholinergic-intemeurons. Ach and muscarinlc agonlsts produce a striatal increase in $\mathrm{Ca}^{2+}$-dependant cGMP levels. The last data is consistent with the presence of muscarinlc receptors in neurons that express NOS and moreover, there is structural evidence suggesting that these cells are Innervated by cholinergic terminals (Phelps, 1985). Glu, DA and oplold-receptors agonists also produce an increase in striatal cGMP levels (Minneman \& Iversen, 1976; Foster \& Roberts, 1980). This data suggests that NOS-Interneurons may regulate the efferent response of the gabaergic medium-sized splnal neurons, whlch recelve afferent stimulus from cortex, substantla nigra and local clrcults (Vincent \& $\mathrm{Ho}$ pe, 1992). Fig. 1 presents a diagram of the structures and connections studied in the present thesis.

Some neurodegenerative diseases have been assoclated wlth the neuronal clrcuitry in basal ganglia. It was clearly established that the most critical abnomality in Parkinson's disease is the degeneration of the nigrostriatal dopaminergic system, and that the principal characteristic of the chorea in Hungtinton's dlsease is a marked loss of striatal neurons. However, although Alzhelmer's disease and dementla of Alzheimer's type are primarily associated with deficlts of cerebral cortex and hippocampal formation, some of the symptoms presented by these 
diseases are also linked to dysfunctions of the basal ganglia (Herrera-Marschitz \& Ungerstedt, 1990). Furthermore, deficits of mesolimbic and mesocortical dopaminergic transmission have been associated with several functional syndromes, such as psychosis (Carlsson, 1990), drug addiction (Koob, 1992), schlzophrenia and obsessive-compulsive diseases (Swerdlow, 1987)

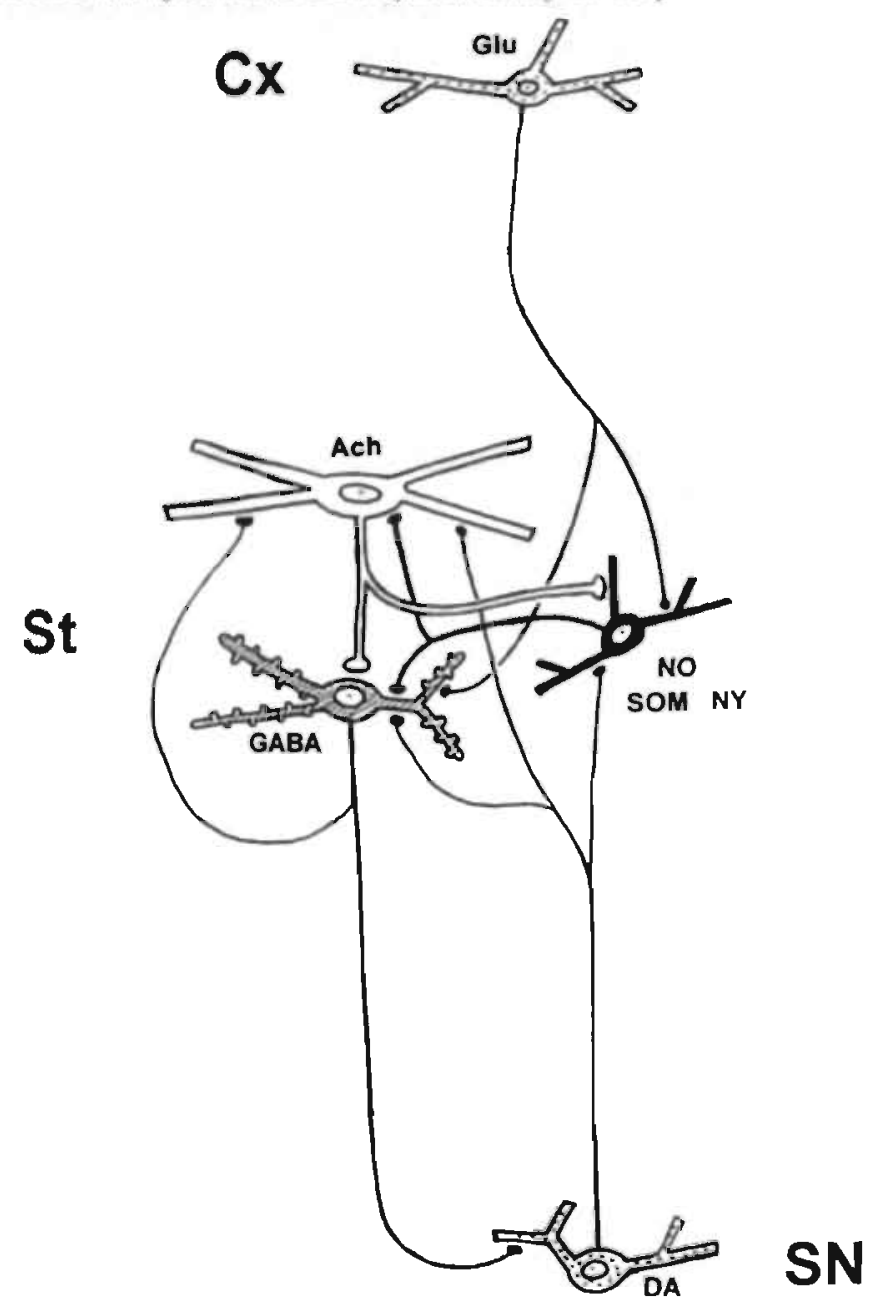

Fig 1: Diagram shows the most established cell nerve connections, Pheir classical and putative neurvtransmit. ters, in transverse sections at cortico-stribto-nigral level. Large non spiny intemeuran-conteining Ach is represented in white; mediurn-sized non-spiny intemeuron eastaining NO, SOM and NY is in black two types of spiny projective neurons-containing 6 GABA projecting their' axons to SN and GP are represented together in one neurnn in stripes. Nigrostriatal and cortical neuron; are represented with spots. Abbreviations: St, striatum; SN, sub. stantia nigra: $C x$ cerebral cortex Glu, glutamate; Ach, acetylcholine; NO, nitric oxide; SOM, somatostatine; WY, neuropeptide $Y$; GABA, gamma-aminobutyric acid; DA, dopamine. 


\subsection{POSSIBLE NEUROTOXIC MECHANISMS INDUCED BY ASPHYXIA}

Under normal conditions, the brain uses, oxygen and glucose in the form of ATP for its required energy. In seconds, ischemia produces a rapid decrease - or cessation - in oxidative phosphorylation and when this occurs, the only source of energy left is that of anaerobic glycolysis, which is not sufficient to maintain a normal cerebral function. Consequently, the brain is forced to utilize is stored glucose and glycogen, which only lasts for $2-3$ minutes. The braln also contalns a creatin-kinase enzyme that functions as a catalyzer to convert phosphocreatine into ATP, but this only helps for one minute longer. It is at this point that a last cerebral defensive mechanlsm is triggered since the Increase In cytosol of ADP molecules stimulates another source of energy: the adenyl-kinase enzyme, whlch converts two ADP molecules in ATP plus AMP. In asphyctic conditions and with the help of this enzyme, the brain has approximately 5-10 minutes longer before consuming its available ATP.

If this energy failure is sustained in time, different cellular degenerative mechanisms such as (1) excitatory aminoaclds release, (2) free radlcals generation, (3) niuric oxide and other neurotransmitters release, (4) lactic acid accumulation, (5) massive entrance of calcium and ( 6 ) degradation of the membrane phospholiplds amongst others will be triggered (Farooqui, 1994). In this condition, neurological damage or death may follow. The principal neurotoxic mechanisms involved in hypoxia are depicted in Fig. 2.

2.3.1 Excessive excitatory aminoacids release: In mammals, glutamate (Glu) is the principal endogenous excitatory aminoacid in the CNS. It couples with at least 5 subtypes of receptors, amongst which NMDA, kalnate, AMPA and metabotropic trans-ACPD are the most Important. There is strong evidence that in a state of hypoxla-ischemla an overstimuladon of excltatory aminoacids release (glutamate and aspartate) plays an important role In the pathogenesis of cerebral damage and therefore, the competitlve and non-competitive antagonists of N-methyl-D-aspartate (NMDA) receptors and those of alphaamino-3-hydroxy-5-methyl-4-isoxalepropionic acid (AMPA) have been suggested as neuroprotective agents (Scatton, 1991; Barks \& Silverstein, 1992; Sheardon, 1990).

The Idea that these aminoaclds play a neurotoxlc role emerges from the following facts: (1) the most vulnerable areas of the brain (hippocampus, cerebral cortex, striatum and cerebellum) receive strong glutamatergic inputs, (2) leslons in these pathways prevent the neuronal damage induced by Ischemla, (3) high concentrations of extracellular glutamic acld have been registered in these regions after Ischemia and (4) a local micro injection of NMDA antagonists prevents the neuronal damage induced by ischemia (Cervos-Navarro, 1994). 


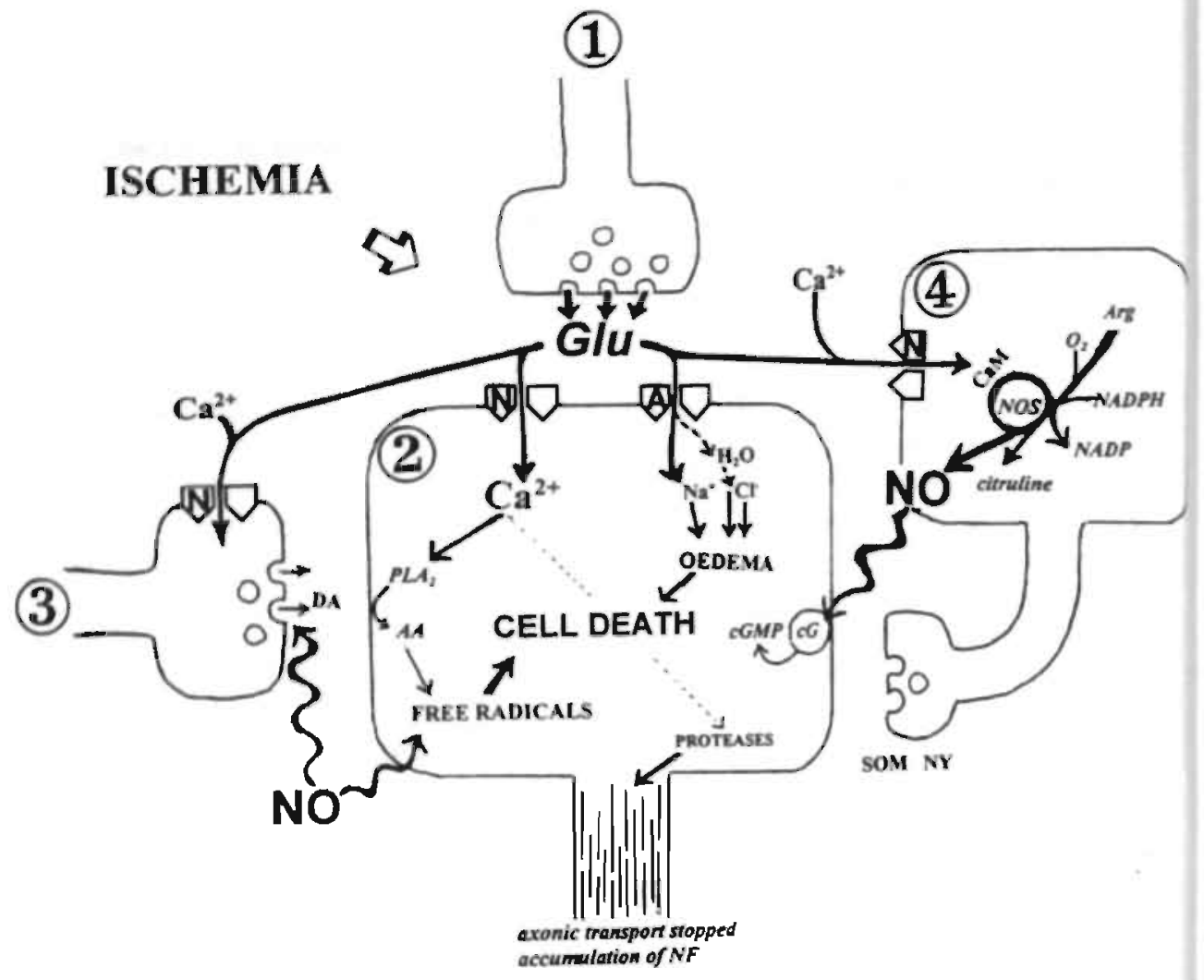

Fig 2: Possible mechanisms involved in striatal neurotoxicity. 1. Corticostriatal nerve en. ding. 2. Striatal spiny projective neuron-containing GABA, 3. Nigrostriatal nerve ending, 4. Medium-sized nom-spiny interneuron-containing HOS, SOM and WY. Abbreviations: N: MMDA receptor; A: AMPA receptor; PLA ,: phospholipase $A_{2}$; AA: araquidonic acit: Gc: soluble guanylato cyclose; WY: neuropeptide $Y_{\text {; }}$ SOM: somatostatine; HOS: nitric oxide synthase; CaW: calmoduline; NF: neurofilaments. 
When neurons are exposed to an excess of glutamate, an acute neuronal oedema occurs as a result of an active depolarization with cellular entrance of $\mathrm{Na}^{+}$, $\mathrm{Cl}$ and $\mathrm{H}_{2} \mathrm{O}$ together with $\mathrm{N} ₫$, $\mathrm{K}-\mathrm{ATPase}$ channel inhibition. This process can be reversed if Glu is rapidly removed from the zone; but if the exposure is sustalned, the entrance of water into the cells produces an osmotic swelling that alters the neuronal function. Moreover, a NMDA receptor stimulation speeds up channels, permitting an excessive entrance of $\mathrm{Ca}^{2+}$ and it is known that an intracellular increase in this ion activates lipases, phospholipases, proteases and proteinkinases, which can produce considerable cell damage if not properly regulated (see Fig. 2).

The hypothesis that neuronal degeneration is the result of an excessive release of excitatory aminoacids presents some weak points: (1) the hippocampal CA4 region has a low concentration of NMDA and yet is highly vulnerable to an ischemic insult, and (2) hippocampal neurons of the gyrus dentatus, a resistant zone to ischemia, has a high density of NMDA receptors.

2.3.2 Free radicals production: It is accepted that reperfusion after ischemia stimulates the production of free radicals. An indirect biochemical fact that demonstrates this production of free radicals and lipidperoxidation In ischemia is the reduction of endogenous antloxidants such as ascorbate, glutathione, ublquinone, $\alpha$-tocopherol and cholesterol in the cerebral tissue. Some of the most common radicals formed are: superoxide anlon $\left(\mathrm{O}_{2} .^{-}\right)$, hydrogen peroxide $\left(\mathrm{H}_{2} \mathrm{O}_{2}\right)$ and the hydroxyl radical $(\mathrm{OH})$, catalyzed by cyclooxygenase and lipooxygenase enzyme activities and the Fenton reaction. Radicals are also produced by catecholamine autoxidation and xanthinoxidase. The slgnlficance of each of these processes is still not clear, but all of them are capable of producing free radicals during reperfusion. Recently, another oxygen radical, peroxynitrite anlon (ONOO), has been proposed as a toxic agent in Ischemia (Farooqui, 1994).

There is a type of enzymes called superoxide dismutase (SOD), catalase and glutathione peroxydase that is involved in the cerebral defense from free radicals formation. SOD mutations are assoclated with amyotrophlc lateral sclerosis (ALS), a degenerative disease of the motor neurons in cerebral cortex, medulla and spinal cord (Rosen, 1993). This is a clear example where damage produced by free radicals is associated with a defect in the genetic code involved In defenslve protein formation against oxidation.

2.3.3. Nitric oxide release: Nitric oxide (NO) is a very important and unusual messenger. Because it is a hlghly reactive and unstable gaseous free radical, it is capable of reacting and changing as soon as it is in a blological environment. NO is naturally generated from the aminoacid L-arginine by nltric oxide synthase (NOS), a NADPH and calclum/calmoduline-dependant enzyme. Two types of NOS have been identified: 1) a constitutive form of NOS (cNOS), dependant upon $\mathrm{Ca}^{2+} / \mathrm{calmoduline}$ that releases NO stimulated by Increase in intracellular $\mathrm{Ca}^{2+}$ for only short periods of tme and 2) a second form of NOS, inducable nitric oxide synthase (iNOS) that is expressed under cytoklne activation 
of the cells, is not dependant on $\mathrm{Ca}^{2+}$ and it produce NO for long time periods. iNOS is primarily found in macrophages, smooth muscle cells, endothelial cells and hepatocytes.

The observation that neuronal cNOS is Identical to neuronal nicotin-amideadenine-dinucleotide-phosphate diaphorase (NADPH-d) (Dawson,1991; Hope, 1991, Vincent \& Hope, 1992) has allowed the localization of NOS through a hlstochemical method first described by Thomas \& Pearse (1964). The fact that cNOS is a calclum-calmoduline dependant enzyme has led to the hypothesis of a IInkage between NOS and NMDA receptors, which are coupled to calcium ionic channels. In the last years, it was established that NO Increases after stimulation of glutamatergic NMDA (Garthwaite, 1988) due to a NOS activation by calcium Influx through NMDA (Bredt, 1990). The final result is an increase in NO, that activates a soluble guanylate cyclase with CGMP production (Garthwalte, 1988).

It was establlshed that NO is Involved in neurotransmission, vasodilation, neurotoxicity, Inhlbition of platelet aggregation, and the antiproliferative action of cytokines. As a neurotransmitter, the role of this messenger still remains unclear. The interaction between NO and NMDA is particularly Interesting because of the role played by these receptors in neuronal plastlcity, Including sprouting of neurites, symaptic transmission and long-term potentlation (LTP) (Bohme, 1991; O'Dell, 1991; Shuman \& Madlson, 1991, 1994; Hess, 1993; Zhuo, 1993; Montaghe, 1994).

Under ischemic condltions, NO, generated in the brain by neurons and endothelial cells, reacts wlth oxygen radicals forming peroxynitrite, which rapidly decreases produclng highly reactive radicals such as hydroxyl radicals $(\mathrm{OH})$ and nltrogen dloxide $\left(\mathrm{NO}_{2}{ }^{\circ}\right)$. Furthermore, a high concentration of $\mathrm{NO}$ can be toxic to cells, stimulating the ADP-rlbosyltranspherase and through its association with enzymatlc centers contalning Iron-sulphur, Interfering with the mitochondrial electron transport chain, tricarboxylic acld cycle and DNA synthesis (Garthwaite, 1991). Accordlng to different authors, NO could have either neuroprotective or neurotoxic effects. Recently, Lipton \& Stamler (1994) have proposed that NO could have both effects, depending on the redox state of the medium. However, recent results of Terwel et al. do not lend support to thls notion (unpublished data).

2.3.4 Lactic acid accumulation: Cerebral hypoxla-ischemia induces an Increase in lactic acld (Lac) due to a deviation of glycolysis to the anaerobic pathway. An increase in $\mathrm{Lac}$, added to an Increase in $\mathrm{CO}_{2}$ and intracellular protons such as ATP hydrolysis, produces an acldotic state. A decrease in intracellular pH is an optmal medlum for the activity of the hydrolytic enzymes of lysosomes in cerebral tissue, producing a rapid destruction of Nissl granules and neuron al and gillal swelling that leads to cellular death (Nedegaard, 1991). It has been demonstrated that the highest glycose consumption with Lac accumulation in brain after carotid ligatures is produced in the striatum (caudate/putamen), medial thalamus, Ammon's hom and substantia nigra pars reticularis. 
It is interesting to point out that a mild exposure to an acidic medium (pH 6.6) might be neuroprotective because it induces a decrease in NMDA activity (Giffard, 1990; Tombaugh, 1990). However, an important decrease in pH amplifies the neurodegeneratve processes triggered by glutamate excitotoxicity (Chleide, 1991). Studles performed with cell cultures have shown death of neurons and glial cells after a 10 minute exposure to an acidic medium with Lac at $\mathrm{pH}$ of 4.8 . (Goldiman, 1989). Other reports show that local sodlum lactate injections decreasing cerebral $\mathrm{pH}$ to 5 induces cellular swelling, proteins and nucleic acid denaturation, free radicals fortnation, Inhlbition of neurotransmitter reuptake and an alteration in endotheltal cells, leading to a secondary vascular insufficiency. It has also been suggested that the decrease in $\mathrm{pH}$ is partly due to an accumulation of excitatory aminoacids, which opens $\mathrm{Na}^{+}$channels, Inducing oedema, and eventually osmolysis.

2.3.5 Role of calcium: Neuronal calcium is a cellular messenger. It plays an extremely important role in regulating most enzymatic reactions and activating varlous phosphollpases, proteases, proteinkinases and phosphatases. The cytosolic calcium concentration in neurons is regulated by a great variety of membrane pumps and exchange systerns. Most researchers have concluded that the homeostatic alteration produced by a $\mathrm{Ca}^{2+}$ release induced by ischemia is what uitimately leads to degeneration, since there always is an abnormal increase In this ion prior to any kind of detectable damage. A decrease in extracellular levels of calclum can also be observed and there are reports Indicating that both the removal of calcium from the medium prior to ischemla and the utllization of NMDA antagonists prevent neuronal damage.

2.3.6 Excessive release of neurotransmitters: Following Ischemia, the metabolism of most neurotransmitters is altered Indlcating neuronal failure. This is described for Ach, DA, noradrenaline and serotonine, besides GABA and the excltatory aminoacids previously mentioned (Volpe, 1987; Allaln, 1991; Richards, 1993). With the exception of glutamate and aspartate, the Idea that an excessive release of some neurotransmitters after Ischemla, DA in particular, can be cause or effect for neurotoxicity is extremely debatable. Furthermore, NMDA receptors facilitate DA release In striatum (Roberts \&x Anderson, 1979; Cheramy, 1986; Clow \& Jhamandas, 1989,; Moghaddam \& Gruen, 1991), an area that is rich in NOS (Bredt, 1990, 1991). Hypothetically, from a functional polnt of view, NMDA receptors, NO production and DA release might be related. According to this hypothesis, NOS inhibitors mlght block striatal release of DA mediated by NMDA (Hanbauer, 1992). Current blbliography concerning the interaction of NO and DA is contradictory, with some authors reporting a stimulant effect In DA release (Zhu \& Luo, 1992; Lonart, 1993, Tokutake, 1993; Black \& Humprey, 1994a, 1994b) and others an Inhibitory effect (Rose, 1994; Guevera-Guzman, 1994). 
2.3.7 Membrane degradation: During preparations Including cultures, slices and synaptosomes performed with samples of hippocampus, striatum and hypothalamus, It was observed that agonists of excitatory aminoacids via NMDA receptors activate release of arachidonic acid (AA) from phospholipids of the membrane. The release of $A A$ is medlated by phospholipase $A_{2}$, whlch also generates free radicals. Moreover, the activation of metabotroplc-transACPD receptors seems to be the princlpal cause for hydrolysis of phospholnositol by activating a phospholipase $C$.

\subsection{ASPHYXIA AND INTERMEDIATE FILAMENTS IN NEURONS AND GLIA}

In order to resist different types of insults, CNS reacts in a stereotyped manner; and changes observed in the cytoskeleton of glial cells and neurons are an example of this. The enhancement of glial fibrillary acidic protein (GFAP) reactivity, a feature of a damaged brain (Eng, 1987, Nathaniel, 1981), reflects an astrocytic response to brain insult (Eng, 1988; Vllayan, 1990). Following an Insult, the so-called "reactive astrocytes" increase in number and slze, with their speclfic intermedlate filaments (GFAP) Increased (Latov, 1979; Barret, 1981). After damage, changes in neuronal intermediate filaments can also be observed. The most common are called neurofilaments (NF). According to molecular welght glven by their carboxy-terminal portion, 3 types have been described: light, NF-s (68kD), medlum, NF-m (150kD) and heavy, NF-h (230kD) (Geisler, 1983).

Information on subcellular changes associated with astroglial and neuronal intermedlate filaments following Ischemia can help to understand the role of reactive astrocytes in repairing damaged CNS. It can also provide information on the degree of neuronal damage, reflected in the amount of NF. Based on this information, astroglial reactlon and NF content were studled in rats subjected to perinatal asphyxia. 
CHAPTER 3 


\section{MATERIAL \& METHODS}

3,1 Subjects: Sprague-Dawley albine rats were used for all surdies. Rats, in compliance with princlples of animal care and use of laboratory animals, were kept in Indlvidual stainless-steel cages, fed purine chow and given tap water ad libitum. Room temperature was controlled and had a light/dark cycle of 12 hours. Experiments were performed: (1) immediately after birth and (2) at 6 months age.

\subsection{Surgical technique to induce perinatal asphyxia: Asphyxla} was Induced in caesarean-sectlon dellvered pups from pregnant rats. Gestational age of the rat was determined by: estabularium protocols, vaginal smear and clinical palpation performed as of 3 days previous to the expected dellvery day. In a fetus at term, the head can clearly be distingulshed from the body. Furthermore, the mother Is In a hypoactlve state, frequently llcking vaginal blood and Instinctively building a nest when paper is placed in its cage. In the last gestational day, rats were anaesthetlzed wlth ether, hysterectomized and killed. The isolated uterus homs containing the feuses were extracted, detached, and placed in a water bath at $37^{\circ} \mathrm{C}$ for several periods of time before the delivery of the pups. Since each rat dellvered 12 to 15 pups, controls delivered by caesarian-section and asphyctic pups were obtained from one same mother. Following asphyxla, uterus homs were rapldly opened and pups removed. Pups were stimulated to breathe by cleaning delivery fluid and performing tactle stimulation on oral region with medlcal wipes. The umbilical cord was ligated, and pups were left to recover for 40-80 minutes on a heating pad before giving them to surrogate mothers. Pups delivered spontaneously by rats in the course of the experiments were used as spontaneously vaginal delivered controls. Time of asphyxia was measured as the time elapsed from when blood circulation to the uterus was cut off to the moment when pups started to breathe. Only male pups within the following parameters (1) occipltocaudal length $>41 \mathrm{~mm}$ and (2) body weight $>5.0 \mathrm{~g}$ were included in the experlments. Rats that delivered normally within $\mathbf{4 8}$ hours before experiments were utilized as surrogate mothers. Each surrogate mother rat recelved 4 asphyctic male pups, 2 male control pups delivered by rapid caesarea and retalned 2 of its own male pups, as normally delivered control animals. Each mother had a final litter of 8 pups to care for untl weaning. Pups selected for the study of PA long-term effects were marked by cuttng of different nails and left to grow untl 6 months of age. Steps of the model used are shown in Fig. 3. 


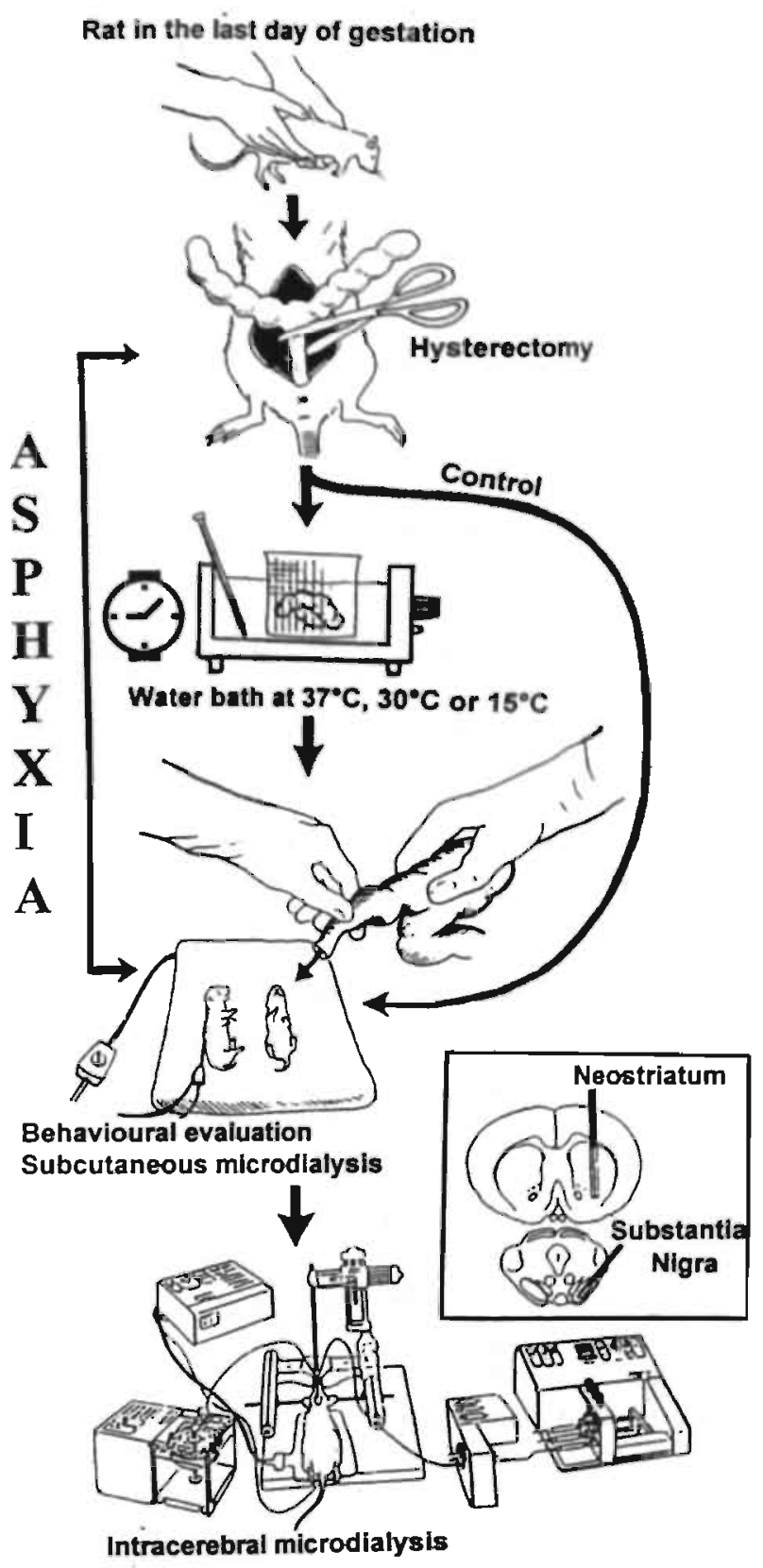

Fig 3: Diagram of the methodology to induce PA 
3.3. Behavioural studies: Through direct observation, and in pepds of 40-80 minutes after delivery, several parameters were recorded : (i body weight, (ii) survival, (iii) respiratory frequency, (Iv) gasping, (v) vocallzatic, (vi) skin colour, and (vil) spontaneous movements. These were scored accorng to the following scale: (0) akinesia and rigidity (mainly of hind legs); (1) motment of one of the following body structures: front legs, hind legs or head alor; (2) movement of two of the body structures; (3) movement of all body strurres; (4) Intenslve movements shown by wriggling (Loldl, 1994). The term "gping" refers to the effort to maintain respiration expressed by the openlng of the routh and movements of the diaphragm.

\subsection{Mlcrodialysis technique}

3.4.1 Brief description: Microdialysls is a recent neurochemlcal tecnique that permits to study in vivo mechanisms of neurotransmitter release (Ungstedt, 1982). It is a simple technique that to a certain extent imitates the physiogy of caplllaries. It Is composed of a microdialysis fiber that consists of a steepl with

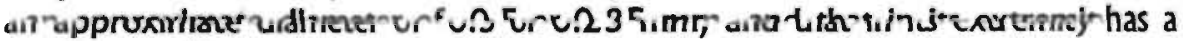
semipermeable membrane capable of obtaining, by simple diffusion, chemical components with low molecular welght from the extracellular space (see Fig. 3 and 4). Then, through a known liquid e.g. artificial cerebro spinal fluid (CSF), different substances can enter or leave the fiber through the membrane (see Fig. 3 ). Therefore, a later measurlng of substances in the dializated llquid of perfusion is posslble. Generally, the most widely used method to analyze collected samples Is the hlgh performance liquld chromatography (HPLC), coupled to electrochemical and fluorometric detectors (Ungerstedt, 1982). Introduction of drugs together with the perfuslon liquild is also possible. Thls allows to measure chemical changes in the extracellular space.

In order to study PA short-term effects, a mlcrodlalysls fiber was implanted in the subcutaneous tissue of asphyctic and normal pups, thus allowing changes in glutamate (Glu), aspartate (Asp), lactate (Lac), pyruvate (Pyr) and ascorbate (Asc) to be measured (Flg. 4).

Long-term effects in 6 months old rats were studled with intracerebral microdialysls. The nucleus studied were strlatum and substantia nigra. Extracellular levels of DA, GABA, Ach, Glu, Asp and metabollc products Lac, Pyr and Asc were evaluated in asphyctic and normal rats (Fig. 4) 


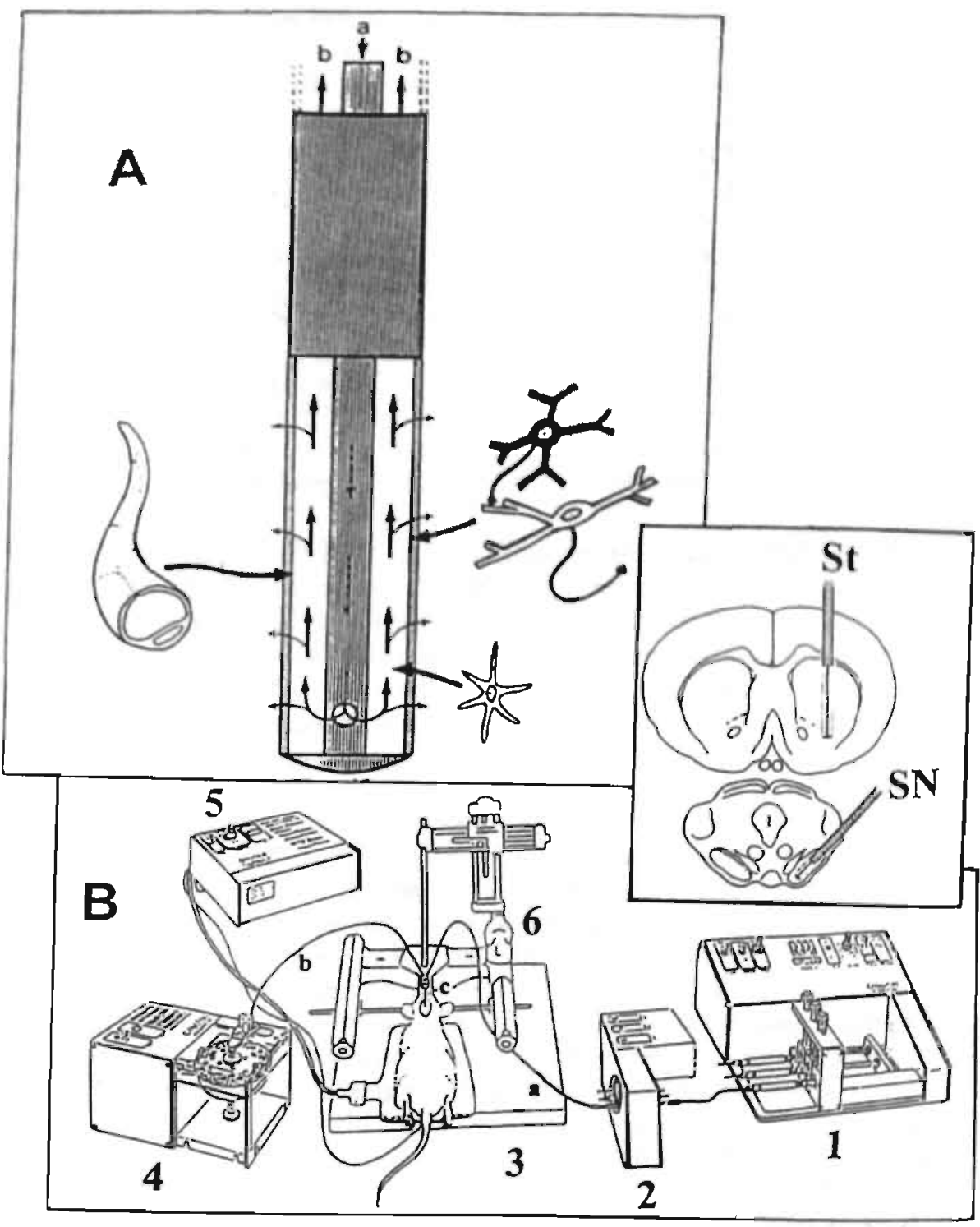

Fig 4: A: Transverse section of the microdialysis probe. Arrows indicate the path of perfused liquid, (a) inner canulae to perfusion liquid, (b) outor way to dialized liquid. B: Diagram of set employed for microdialysis technique, 1-perfusion pump coupled to microsyringes, 2-automatic switcher to micro. syringes, 3- (a) inner canulace, (b) outer canulae, (c) microdialysis probo (seo direction and size of intro. cerebral probes in striatum [St/ and substantia nigra /SWI]; 4-automatic callector of samples, 5. auto. matice body temperature controller, and 6- steraotaxic frame. 
3.4.2 Subcutaneous microdialysis in newborn rats: Approximately 40 minutes after delivery both spontaneous vaginal and caesarean-section controls, as well as asphyctic pups, were implanted with a flexible microdlalysis probe In the subcutaneous ttssue of the dorsal region, in a caudo-rostral orientation, parallel to the spinal cord. Microdialysis probes (dialyzing length $=4 \mathrm{~mm}$; dlameter - $0.5 \mathrm{~mm}$ ) were perfused with a modified CSF solution $(148 \mathrm{mM} \mathrm{NaCl}, 2.7 \mathrm{mM}$ $\mathrm{KCl}, 1.2 \mathrm{mM} \mathrm{CaCl}_{2}, 0.85 \mathrm{mM} \mathrm{MgC}_{2} ; \mathrm{pH} 7$ ) at a constant flow of $2 \mu \mathrm{l} / \mathrm{min}$ that was malntained with a microdialysis pump. After two 20 minute samples, the mlcrodlalysis probe was carefully removed, the wound sealed with a drop of acryl blue (Histoacryl, B. Braun Melsungen AG, Germany) and the pups were given to surrogate mothers. Samples were split In $10 \mu$ aliquots and were directly injected Into hlgh-performance liquld chromatography (HPLC) systems, coupled to a fluorometric or an ultraviolet detector to analyze Glu and Asp or Lac, Pyr and Asc respectlvely. Means and standard errors of means (SEM) were calculated and differences were tested with Flsher (F) ANOVA tests. A level of $\mathbf{P}<0.05$ for the two-talled test was considered critical for statistical significance.

\subsubsection{Intracerebral microdialysis. Study of the nigrostriatal}

system: After 6 months $(-500 \mathrm{~g}$ wt.), asphyctlc and control rats were anaesthetized wlth halothane, placed in a Davld-Kopf stereotaxic frame and two microdialysls probes were implanted, one in the left striatum (coordinates: B 0.5, $\mathrm{L}-3.2, \mathrm{~V}-7.2)$ (dialysis length $=4 \mathrm{~mm}$; dlameter $=0.5 \mathrm{~mm})(\mathrm{CMA} /$ microdlalysis AB, Stockholm, Sweden) and another in the left substantia nigra ( B -6.2, $L$-7.6, V -8.6; Inserted at a $40^{\circ}$ angle from vertical in the coronal plane) (dialyzing length $=2 \mathrm{~mm}$; dlameter $=0.5 \mathrm{~mm}$ ), according to the Atlas of Paxinos \& Watson (1986) (see Flg. 4). Mlcrodialysis probes were perfused with a modified CSF solution $(148 \mathrm{mM} \mathrm{NaCl}, 2.7 \mathrm{mM} \mathrm{KC}, 1.2 \mathrm{mM} \mathrm{CaCl}, 0.85 \mathrm{mM} \mathrm{MgCl} ; \mathrm{pH}$ 7). A constant flow of $2 \mu \mathrm{l} / \mathrm{m} / \mathrm{n}$ was maintained throughout the microdialysis experiment. Anaesthesia was performed by free breathing into a mask fitted over the nose of the rat $(1 \%$ halothane in air flow of $1.5 \mathrm{l} / \mathrm{min})$. Body temperature was kept at $37^{\circ} \mathrm{C}$ using a temperature control system (CMA/150, $\mathrm{CMA} / \mu$ dialysis $\mathrm{AB}$ ). Samples (each of $80 \mu \mathrm{l}$ every $40 \mathrm{~min}$ ) were collected automatlcally (CMA/140, $\mu$ dialysls $A B$ ) and directly injected Into hlgh performance Ilquid chromatography systems, coupled to electrochemical detection (HPLC-EC) systems for DA and its metabolites (Herrera-Marschltz, 1992) and y-amino butyric acld (GABA)(Kehr \& Ungerstedt, 1987), acetylcholine and choline (Maysinger, 1988) or to a fluorometric detector system for glutamate (Glu) and aspartate (Asp) (Herrera-Marschla, 1992). Basal values were referred to those obtalned before the administration of $2 \mathrm{mg} / \mathrm{kg}$ s.c. of D-amphetamlne (Sigma, St. Louls, MO, USA) (200 minutes after microdialysls Implantation). Following every mlcrodlalysis experiment, animals were sacrificed, their braln removed and conserved In formallne for lts ulterlor histological study. Means and standard errors of the means (SEM) were calculated and differences were tested with Fisher (F)-ANOVA test. A level of $P<0.05$ for the two tailed test was considered critical for statistical significance. 


\subsection{Possible therapeutic agents tested during experimental pe rinatal asphyxia}

- Hypothermia: The model to induce PA was also performed under hypothermic conditions at $30^{\circ} \mathrm{C}$ and $15^{\circ} \mathrm{C}$ in order to study the possible protective effect of cold-treatment. Once PA was started, shlfts In ternperature from $37^{\circ} \mathrm{C}$ to $15^{\circ} \mathrm{C}$ were performed.

- Drugs: In a series of experiments, the non-competitive NMDA antagonlst Dizocilpine, (+)-MK 801 hydrogen maleate $1 /+1-5-$-methyl-10,11-dithdro-5H-dibenzo $\{a, d\}$ cyclohepten-5, 10-imine maleate; RBI, Natick, MA, USA (dissolved in sallne) $(0.2$ $\mathrm{mg} / \mathrm{kg}$ s.c.) or the AMPA antagonist NBQX [2,3-dihydroxy-6-nitro-7.sulfamoyl-benzo(F) quinoxaline], Novo Nordisk A/S, Mallov, Denmark (dissolved with a drop of $\mathrm{NaOH}$ in $5 \%$ glucose) was administered in a single dose to mothers, one hour before dellvery. Comparisons on rate of survival were established with non-parametric Cochran's test (Q). A level of $\mathrm{P}<0.05$ was considered critical for statistlal significance.

\subsection{Cresyl violet histology:}

At 6 months of age, control, asphyctic and treated rats were sacrlficed with $28 \mathrm{~g} \%$ chloral hydrate, $0.1 \mathrm{ml} / 100 \mathrm{~g}$ of body weight. Bralns were removed, fixated in formalin, and coronal sections including striatum and neocortex were collected using an Oxford vibratome (40 $\mu \mathrm{m}$ thick) and stained with Cresyl vlolet. Bllateral counts of vlable looking neurons (well-defined nucleus and nucleoll, not shrunken) were performed by an observer blind to treatment conditions. Neurons were counted in the lateral, medlal, dorsal and ventral strlatum at bregma $-0.40-$ interaural 8.6 and neurons in the medlal and lateral sectors of neocortex were counted at bregma -0.40- interaural 8.6 (Paxinos \& Watson, 1986). 


\subsection{Immunocytochemistry. Sternberger's peroxidase anti- peroxidase (PAP) method (1986):}

The following primary antbodies were used: antiglial fibrillary acidic protein (GFAP), as a marker of astrogllal response to PA, and anti-neurofilaments protein (NF), with 68,160 and $230 \mathrm{kD}$ molecular welght, as neurodegenerative markers.

Adult animals were l.p. anaesthetized with $28 \mathrm{~g} \%$ chloral hydrate, $0.1 \mathrm{ml} / 100 \mathrm{~g}$ body welght, and perfused through the abdominal aorta (Gonzalez Aguilar \& De Robertis, 1963). Rats were perfused with $4 \%$ paraformaldehyde, $0.25 \%$ giutaraldehyde in $0.1 \mathrm{M}$ phosphate buffer, $\mathrm{pH} 7.4$. Coronal sections from the brain containing striatum, and others containing substantia nigra (40/m thick) were cut In an Oxford vlbratome. Sections from treated and control animals were simultaneously processed. For each step of the immunohistochemical procedures, accordlng to Sternberger's peroxidase-antiperoxidase (PAP) method (1986), the same protocol was used. Free floating sectlons were Incubated either for GFAP or NF in the following sequence: (1) incubation in $3 \%$ normal goat serum (NGS) for 30 minutes; (2) Incubation with the primary antibody, polyclonal anti-GFAP, monocional antl-NF (of the three types) In $1 \%$ NGS $(v / v)$ at $4^{\circ} \mathrm{C}$ for 48 hours; (3) Incubation for 60 mlnutes In the secondary antibody (sheep polyclonal antirabblt) in 1\% NGS (v/v) for GFAP; goat-monoclonal ant-mouse in $1 \%$ NGS $(v / v)$ for NF; (4) Incubation for 45 minutes in PAP dlluted $1: 100$ in $1 \%$ NGS $(v / v)$; (5) development for $15-30$ minutes in $0.035 \%$ DAB containing $2,5 \%$ (w/v) nickel ammonium sulphate, and $0.01 \% \mathrm{H}_{2} \mathrm{O}_{2}$ in $0.1 \mathrm{M}$ acetate buffer $(v / v)$ pH 6.0 (Hancok, 1984); (6) sections were mounted on glass slides, dehydrated, and examined in a Zelss Axiophot photo microscope.

\subsection{NADPH-diaphorase histochemical technique:}

Technique in pups: Pups surviving asphyxia, caesarean delivered controls and hypothermlc-treated pups ( 5 In each group) were immedlately decapitated following the first 30 minutes of recovery after blrth. Brains were directly fixated for 24 hours in $4 \%$ paraformaldehyde in $0.1 \mathrm{M}$ phosphate buffer, and then immersed ovemight in a solution containing $5 \%$ sucrose in $0.1 \mathrm{M}$ phosphate buffer pH 7.4. After belng fixated, the brains of the pups were cut on a Leltz cryostat in sections of $20 \mu \mathrm{m}$ and placed on gelatin-coated glass slides.

Technique in adult rats (6 months): Animals were perfused following the method described above and post-flxated In the same solution for 2 hours. Brains were cut in coronal sections (40 $\mu \mathrm{m}$ thlck) containing the striatum in an Oxford vibratome and placed on gelatin-coated glass slides. 
Then, for both pups and adult rats the same protocol for each step of NADPH-d histochemical mechod was used (Vincent \&. Kimura, 1992). Cerebral sections from treated and control animals were simultaneously processed. In short, sections were incubated for 1 hour at $37^{\circ} \mathrm{C}$ in a solution containing $0.1 \% \beta-N A D P H$ and $0.02 \%$ nitroblue tetrazolium diluted in $0.1 \mathrm{M}$ phosphate buffer with $0.3 \%$ Triton X-100 (all reagents purchased from Sigma, St. Louis, MO, USA). Sections were placed in PBS/glycerol $(1: 3)$ and observed and photographed with a Zeiss Axiophot microscope.

\subsection{Computerized Image Analysis:}

NADPH-d and Cresyl violet stained neurons were quantitatively measured using a computerized image analyzer (Kontron-ZEISS VIDAS). The selected fields were located in the lateral, medial, dorsal and ventral areas of the striatum and the medial and lateral sectors of the neocortex. Adequately labelled sections, $40 / \mathrm{m}$ thick, from striatum and surrounding neocortex were randornly selected. Ten cells per section were analyzed with a total of 100 per group. Observations and measurements obtained in the light microscope were transferred to a video camera attached and connected to an Interactive image analysis system on IIne, Kontron-ZEISS VIDAS. Images were digitized Into an array of $512 \times 512$ plxels corresponding to $140 \times 140 \mu \mathrm{m}$ (40X primary magnification). Resolution of each pixel was 256 (gray levels). After automatic normalization of the gray-scale, interactive delineation and contrast enhancement of Images were performed, removing all interfering non-speclfic Images. The projected surface of NADPH-d and Cresyl violet neurons was measured using morphometry: area, perimeter and maximum-minimum dlameter form factor (F-shape). Data count in the measured field was stored and represented the number of positlve structures in each fleld. Mean and SD were calculated for the different fields studled In asphyctic, treated and control groups.

\subsection{Statistical analysis:}

Differences between means and S.D. of experimental and control groups were statistically analyzed using one-way analysis of variance (ANOVA) and later the Newman-Keuls test, a $P<0.05$ being considered slgniffcant. ANOVA and Newman-Keuls tests were routinely performed with an IBM compatible PC AT 486 package software (Primer, Mc Graw Hill, Inc.). 
2 
CHAPTER 4 


\section{RESULTS}

4.1 The experimental model. Protection from mortality in PA by hypothermia: A non-invasive animal model to study short- and long-term consequences of hypoxic-lschemic leslons, simllar to those produced under labour in clinical situations, was developed in rats. The findings were: 1) in a water bath at $37^{\circ} \mathrm{C}$, a PA lasting longer than 22 minutes led to $100 \%$ mortallty wlthin the first 20 minute perlod after dellvery; 2 ) when the uterus containing the fetuses was kept for 22 minutes in a $30^{\circ} \mathrm{C}$ water bath, $100 \%$ of the pups recovered resplratory function following tactlle oral stimulation and were accepted by surrogate mother; 3) the protective effect of hypothermla at $30^{\circ} \mathrm{C}$ allows for a 47.48 minute asphyctlc perlod and, 4) when asphyxia was Induced In a water bath at $15^{\circ} \mathrm{C}$, the $100 \%$ survival rate was extended to 101 minutes.

Fig. 5 shows survival percentage in animals exposed to different asphyctic periods of tme at $37^{\circ} \mathrm{C}$ and Fig. 6 compares survival $\%$ at $37^{\circ} \mathrm{C}, 30^{\circ} \mathrm{C}$ and $15^{\circ} \mathrm{C}$. According to survlval \% at $37^{\circ} \mathrm{C}$, PA was classifled Into slight (5-6 minutes and 10-11 minutes), moderate (15-16minutes), subsevere (19-20minutes) and severe ( $220 \mathrm{~m} /$ nutes).

\subsection{SHORT-TERM EFFECTS OF PERINATAL ASPHYXIA}

\subsubsection{Survival, behaviour and subcutaneous microdialysis in} asphyctic. control and hypothermic-treated pups: Several parameters were acutely recorded by direct observation (see Tables I-IV) or in vivo microdialysis. After asphyxla, pups were subcutaneously Implanted with $4 \mathrm{~mm}$ flexlble microdialysls probes In the dorsal region, while kept on a heating pad. In this way, subcutaneous levels of aminoacids (glutamate, aspartate), and metabolic products (lactate, pyruvate, and ascorbate) were monitored for 40-60 and 6080 minute perlods after removal of asphyctc and control pups from the uterus (see Flgs. 7-11)

a) Effects of delivery through hysterectomy (caesarea) and normal vaginal delivery: Pups dellvered from uterus homs by hysterectomy on their final day of gestation started regular breathing (respiratory frequency $60 / \mathrm{min}$ ) almost Immediately after dellvery was completed. These control pups presented pink-colored skin and intensive vocallzation and motility. They were accepted by surrogate mothers after an $\mathbf{8 0}$ minute observation period. When pups were accepted, their posterlor development was similar to that of normally dellvered rats (this was seen in the one month perlod of observation). Measurement of subcutaneous levels showed no difference between the two groups and were approximately: glutamate $=2 \mu \mathrm{M}$; aspartate $\approx 0.4 \mu \mathrm{M}$; lactate $1 \mathrm{mM}$; pyruvate $=60 \mu \mathrm{M}$ and ascorbate $20 \mu \mathrm{M}$ 
b) Slight and moderate asphyctic exposure: Following a 2.3 and 5-6 minute asphyctic period induced in a water bath at $37^{\circ} \mathrm{C}$ (slight PA) or $30^{\circ} \mathrm{C}$, all pups started breathing shordly after dellvery. Their behaviour was simtlar to that observed in the control animals (see Tables I and II). Following a 5-6 minute asphyctic period at $37^{\circ} \mathrm{C}$, glutamate levels were $=7.5 \mu \mathrm{M}$; aspartate $=1.2 \mu \mathrm{M}$; lactate $=1.5 \mathrm{mM}$; pyruvate $=150 \mu \mathrm{M}$ and ascorbate $=15 \mu \mathrm{M}$. At $30^{\circ} \mathrm{C}$, glutamate levels were $=3.5 \mu \mathrm{M}$; aspartate $=1.6 \mu \mathrm{M}$; lactate $=1.3 \mathrm{mM}$; pyruvate $=150 \mu \mathrm{M}$ and ascorbate $=10 \mu \mathrm{M}$. Following a 15-16 minute asphyctic period Induced in a water bath at $37^{\circ} \mathrm{C}$ (moderate $\mathrm{PA}$ ) or $30^{\circ} \mathrm{C}$, all pups survived, presenting no difference in skin colour or respiratory frequency when compared with control animals. Although slight decrease in spontaneous motillty was observed, all pups were accepted by surrogate mothers. At $37^{\circ} \mathrm{C}$, glutamate leveis were $=7 \mu \mathrm{M}$; aspartate $=1 \mu \mathrm{M}$; lactate $2 \mathrm{mM}$; pyruvate $=60 \mu \mathrm{M}$ and ascorbate $=15 \mu \mathrm{M}$. At $30^{\circ} \mathrm{C}$ glutamate levels were $=3 \mu \mathrm{M}$; aspartate $=1 \mu \mathrm{M}$; lactate $1.5 \mathrm{mM}$; pynuate $\approx 60 \mu \mathrm{M}$ and ascorbate $\approx 5 \mu \mathrm{M}$.

c) Subsevere asphyctic exposure: After a 19-20 minute asphyctic period at $37^{\circ} \mathrm{C}$, pups had to be intensively stimulated in order to start breathing. Surviving pups remained akinetic for a long period after dellivery and showed a significant decrease in respiratory frequency $(=20 / \mathrm{mln})$, accompanled by gasping and a pink/pale skin coloratlon. Approximately $30 \%$ of the pups died shortly after delivery. In contrast, at $30^{\circ} \mathrm{C}$ all pups survived a $19-20$ minute asphyctic period. However, initial gasping, a slight decrease In resplratory frequency $(\approx 40 / \mathrm{min})$ and motility was observed. Skin colour was slmilar to that of control pups. All surviving pups were accepted by surrogate mothers. At $37^{\circ} \mathrm{C}$, glutamate levels were $\approx 5 \mu \mathrm{M}$; aspartate $\approx 0.5 \mu \mathrm{M}$; lactate $2 \mathrm{mM}$; pynuvate $\approx 60 \mu \mathrm{M}$ and ascorbate $\approx \mu \mathrm{M}$. At $30^{\circ} \mathrm{C}$, glutamate levels were $\approx 5 \mu \mathrm{M}$; aspartate $\approx 1 \mu \mathrm{M}$; lactate $2 \mathrm{mM}$; and pyruvate $\approx 40 \mu \mathrm{M}$ and ascorbate $\approx 12 \mu \mathrm{M}$.

d) Severe asphyctic exposure: After a prolonged asphyctlc period at $37^{\circ} \mathrm{C}$ ( $220 \mathrm{~min}$ ), rate of survival rapldly decreased and, In general, the physlological condition of the survlving pups deterlorated (Increased gasplng, decreased respiratory frequency, lack of vocallzation, akinesla and pale skin). No pups survived asphyctic perlods longer than 22 minutes. In contrast, at $30^{\circ} \mathrm{C}$, all pups survived up to a 30-31 minute asphyctic period, although some signs of physlological impairment (presence of gasping, decrease In respiratory frequency and motillty and pale skin) were observed. At this temperature, $40 \%$ survival was observed after a 47-48 minute asphyctic perlod. All surviving pups showed gasplng, decrease $\ln$ respiratory frequency $(\approx 10 / \mathrm{mln})$, aklnesla and pale skin. No survlval was observed after asphyctic periods longer than 48 minutes. Following a 21-22 minute asphyctic perlod at $37^{\circ} \mathrm{C}$, glutamate levels were $\approx 4 \mu \mathrm{M}$; aspartate $\approx 0.4 \mu \mathrm{M}$; lactate $2 \mathrm{mM}$; pyruvate $=90 \mu \mathrm{M}$ and ascorbate $=10 \mu \mathrm{M}$. At $30^{\circ} \mathrm{C}$, glutamate levels were $\approx 9 \mu \mathrm{M}$; aspartate $\approx 1 \mu \mathrm{M}$; lactate $2 \mathrm{mM}$; pyruvate $\approx 4 \mu \mathrm{M}$ and ascorbate $\approx 2.5 \mu \mathrm{M}$. 
At $15^{\circ} \mathrm{C}, 100 \%$ survival was observed to up to 101 minutes of asshyxia (see Fig. 6). Following a 50-51 minute asphyctic period, gasping was obseved in $50 \%$ of pups, respiratory frequency was $\approx 40 / \mathrm{min}$, vocalization and notility decreased and skin was pink/pale. Following a 100-101 minute asphyctic seriod at $15^{\circ} \mathrm{C}$, gasping was observed In all pups and respiratory frequency was $10 / \mathrm{min}$. Pups were akinetic and pale, and no vocallzation was observed (Table II). All substances measured by microdlalysis in subcutaneous tissue were simllar to those observed in control group.

In a serles of experiments the water temperature was rapidly shiftec from $37^{\circ} \mathrm{C}$ to $15^{\circ} \mathrm{C}$ in different asphyctlc periods. High preventlon of mortalty was obtained when shifting was done before the first 15 minutes of PA. The ooner the shifting was performed, the hlgher the prevention of mortallty was. (Fi 12).

\subsubsection{Effects of the antagonists of glutamate receptors: Tble IV} shows the effect of pretreatment with saline, dizocilpine (MK-801) $(0.2 \mathrm{ng} / \mathrm{kg}$ s.c.) or NBQX $(10-30 \mathrm{mg} / \mathrm{kg}$ s.c.) (no effects were observed after NBQX 3 $\mathrm{mg} / \mathrm{kg}$ s.c.) administered to mothers one hour before hysterectomy (ontrol group) or hysterectomy followed by $\mathbf{2 1 - 2 2}$ and $\mathbf{2 2 - 2 3}$ minute asphyctic periods at $37^{\circ} \mathrm{C}$. Survival after a $21-22$ minute asphyctic period at $37^{\circ} \mathrm{C}$ was lightly

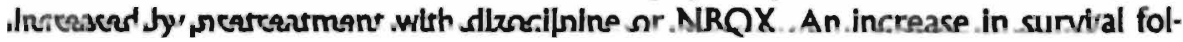
lowing a 22-23 minute asphyctlc perlod at $37^{\circ} \mathrm{C}$ was observed only when the highest dose of NBQX (30 mg/kg s.c.) In assoclatlon with MK-801 was administerd (see Flg. 13)

4.2.3 NADPH-d histochemical staining in asphyctic, control and hypothermic-treated pups: In control pups born through caesarea or natural vaginal delivery, NADPH-d $(+)$ cells were present only in the lateral zone of the neostrlatum, near the corpus callosum and at the end of corpus callosum (see Fig. 14 and Fig 23a). Few stained cells $(6 \pm 2)$ were found in control striatal sections and these were either non-polar type or presented short monopolar processes (Flg. 15a). No stained cells were seen in the cortex of control rats (Fig. 16a).

Rats exposed to severe PA showed NADPH-d $(+)$ cells in the same areas as controls did; also, some, were detected in the cortex (Fig. 16c-d). Neurons in striatum presented a greater affinity to staining, and larger and longer processes (Flg. 15c-d). Animals exposed to 100 minutes of PA in hypothermic conditions $\left(15^{\circ} \mathrm{C}\right.$ ) showed the same pattern of staining as controls (Flg 15b and 16b). All groups presented NADPH-d+ rounded cells at the end of the corpus callosum, with no morphological difference between them. 


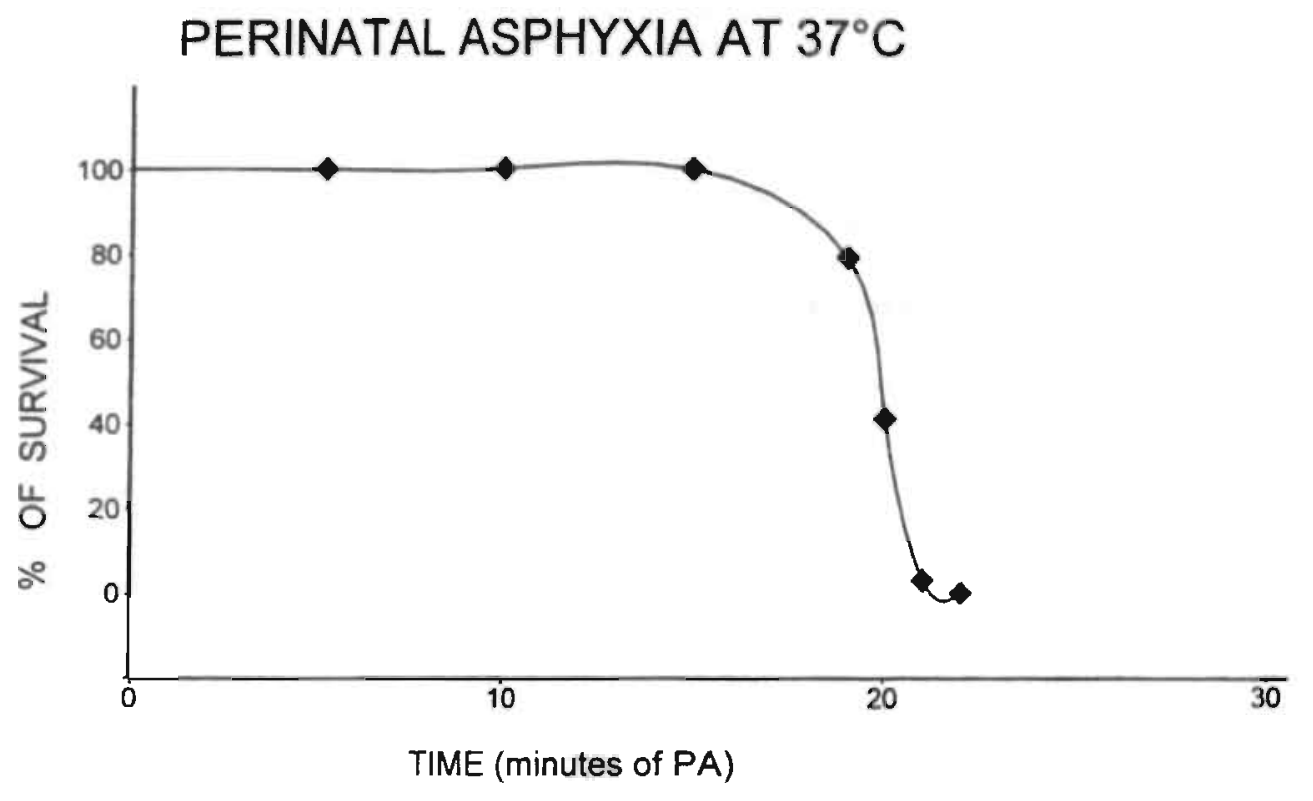

Fig 5: Percentage of survival at different PA periods of tims at $37^{\circ} \mathrm{C}$ 


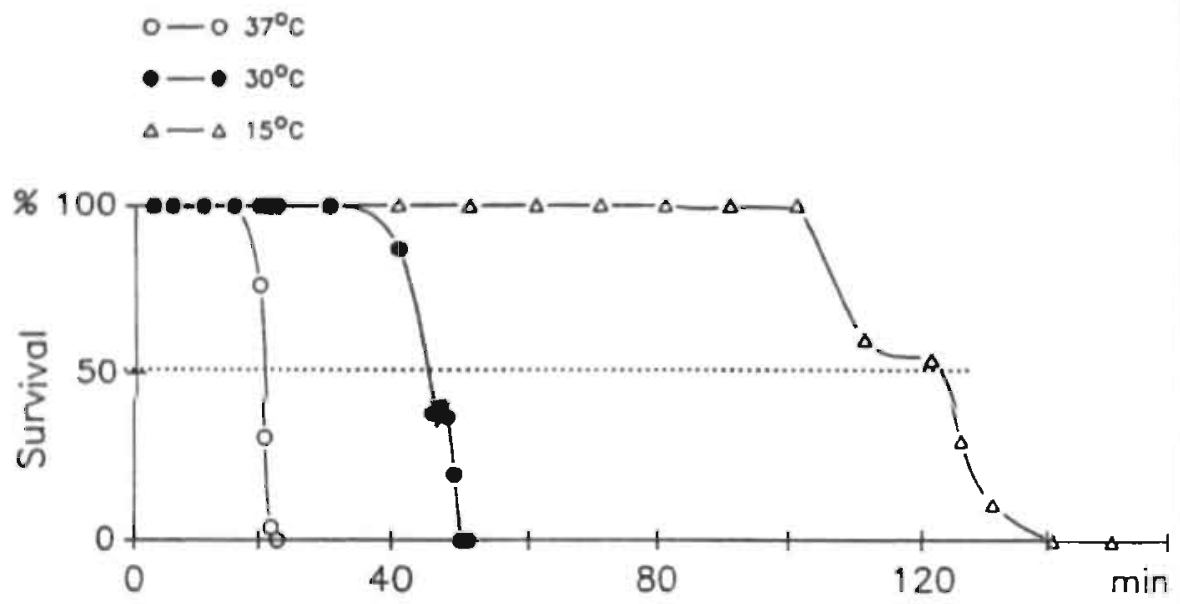

Fig 6: Percentage of survival at diffarent PA periods of time at $37^{\circ} \mathrm{C}, 30^{\circ} \mathrm{C}$ and $15^{\circ} \mathrm{C}$ 
Table I: Short-term effects of PA at $37^{\circ} \mathrm{C}$ monitored by direct observation at $40-60$ min following dellvery. Spontaneous movements were scored according to the following scale: (0) akinesia and rigidity (mainly of hind limbs); (1) movement of one of the following body structures: front limbs, hind limbs or head alone; (2) movement of two of the body structures; (3) movement of all body structures; (4) intensive movements shown by wriggling. Gasping refers to the effort to mantain respiration expressed by the opening of the mouth and movements in the diaphragm.

\begin{tabular}{|c|c|c|c|c|c|c|c|}
\hline $\begin{array}{l}\text { Experimental } \\
\text { condition }\end{array}$ & $\begin{array}{l}\text { Body weigh! } \\
\text { (g) }\end{array}$ & Survival & $\begin{array}{l}\text { Respiratory } \\
\text { frequency }\end{array}$ & Gasping & Vocalization & $\begin{array}{l}\text { Colour of } \\
\text { the skin }\end{array}$ & $\begin{array}{l}\text { Spontaneous } \\
\text { movements }\end{array}$ \\
\hline $\begin{array}{l}\text { [1] Vaginal delivery } \\
(\mathrm{n}=18)\end{array}$ & $6.1 \pm 0.5$ & $100 \%$ & $79 \pm 2$ & $0 \%$ & $100 \%$ & Pink & $3.9 \neq 0.1$ \\
\hline $\begin{array}{l}|2| \text { Caesarean delivery } \\
(n=42)\end{array}$ & $5.8 \pm 0.5$ & $100 \%$ & $74 \pm 2$ & $0 \%$ & $100 \%$ & Pink & $3.8 \pm 0.1$ \\
\hline $\begin{array}{l}\text { [3] PA at } 2-3 \mathrm{~min} \\
(n=4)\end{array}$ & $5.8 \pm 0.5$ & $100 \%$ & $77 \pm 7$ & $0 \%$ & $100 \%$ & Pink & $3.9 \pm 0.1$ \\
\hline $\begin{array}{l}{[4] P A \text { at } 5-6 \mathrm{~min}} \\
(n=1-)\end{array}$ & $5.7 \pm 0.4$ & $100 \%$ & $76 \pm 3$ & $0 \%$ & $100 \%$ & Pink & $3.7 \pm 0.2$ \\
\hline $\begin{array}{l}|5| \mathrm{PA} \text { at } 10-11 \mathrm{~min} \\
(n=12)\end{array}$ & $5.7 \pm 0.3$ & $100 \%$ & $77 \pm 2$ & $0 \%$ & $100 \%$ & Pink & $3.3 \pm 0.2$ \\
\hline $\begin{array}{l}\text { 16] PA at } 15-16 \mathrm{~min} \\
(\mathrm{n}=12)\end{array}$ & $6.0 \pm 0.5$ & $100 \%$ & $61 \pm 3.7$ & $0 \%$ & $83 \%$ & Pink & $2.9 \pm 0.23$ \\
\hline $\begin{array}{l}|7| P A \text { at } 19-20 \mathrm{~min} \\
(\mathrm{n}=33)\end{array}$ & $5.8 \div 0.2$ & $79 \%$ & $32 \pm 3.4$ & $55 \%$ & $6 \%$ & Pink/pale & $0.7 \pm 0.08$ \\
\hline $\begin{array}{l}|8| \text { PA at } 20-21 \mathrm{~min} \\
(\mathrm{n}=23)\end{array}$ & $5.8 \pm 0.3$ & $41 \%$ & $24 \pm 2.6$ & $95.5 \%$ & $0 \%$ & Pale & 0 \\
\hline $\begin{array}{l}|9| \mathrm{PA} \text { at } 21-22 \mathrm{~min} \\
(\mathrm{n}=13)\end{array}$ & $5.9 \pm 0.6$ & $3 \%$ & $18 \pm 3$ & $100 \%$ & $0 \%$ & Pale & 0 \\
\hline $\begin{array}{l}\text { [10] PA au 22-23 min } \\
\qquad(n=132)\end{array}$ & $5.8 \pm 0.2$ & $0 \%$ & . & - & - & - & 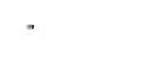 \\
\hline
\end{tabular}


Table II: Short-term effects of PA at $30^{\circ} \mathrm{C}$ monitored by direct observation at $40-60 \mathrm{~min}$ fo delivery.

\begin{tabular}{|c|c|c|c|c|c|c|c|}
\hline $\begin{array}{l}\text { Experimental } \\
\text { condition }\end{array}$ & $\begin{array}{c}\text { Body weight } \\
\text { (g) }\end{array}$ & Survival & $\begin{array}{l}\text { Respiratory } \\
\text { frequency }\end{array}$ & Gasping & Vocalization & $\begin{array}{l}\text { Colour of } \\
\text { the skin }\end{array}$ & $\begin{array}{l}\text { Sponts } \\
\text { move: }\end{array}$ \\
\hline $\begin{array}{l}\text { 1I) PA at 2-3 min } \\
(n=6)\end{array}$ & $5.8 \pm 0.4$ & $100 \%$ & $69 \pm 10$ & $0 \%$ & $100 \%$ & Pink & $3.7=$ \\
\hline $\begin{array}{l}|2| \text { PA at } 5-6 \text { min } \\
(n=17)\end{array}$ & $5.8 \pm 0.2$ & $100 \%$ & $56 \pm 4$ & $0 \%$ & $i 00 \%$ & Pink & $2.8=$ \\
\hline $\begin{array}{l}\text { [3) PA at 10-11 min } \\
(n=11)\end{array}$ & $5.7 \pm 0.4$ & $100 \%$ & $56 \pm 5$ & $0 \%$ & $100 \%$ & Pink & $2.6=$ \\
\hline $\begin{array}{l}\text { [4] PA at } 15-16 \mathrm{~min} \\
(\mathrm{n}=9)\end{array}$ & $5.8 \pm 0.4$ & $100 \%$ & $54 \pm 2.6$ & $0 \%$ & $89 \%$ & Pink & $2.7=$ \\
\hline $\begin{array}{l}\text { [5] PA at 19-20 min } \\
(n=12)\end{array}$ & $6.0 \pm 0.3$ & $100 \%$ & $39 \pm 10$ & $11 \%$ & $22 \%$ & Pink & $2.4=$ \\
\hline $\begin{array}{l}\text { 16) PA at 20.2y min } \\
\quad(n=10)\end{array}$ & $6.0 \pm 0.3$ & $100 \%$ & $47 \pm 5$ & $10 \%$ & $50 \%$ & Pink & $2.7=$ \\
\hline $\begin{array}{l}\text { [7] PA at } 21-22 \mathrm{~min} \\
(\mathrm{n}=19)\end{array}$ & $6.0 \pm 0.3$ & $100 \%$ & $47 \pm 2$ & $14 \%$ & $57 \%$ & Pink/pale & $2.6=$ \\
\hline $\begin{array}{l}\text { [8] PA at } 22-23 \mathrm{~min} \\
(\mathrm{n}=23)\end{array}$ & $6.0 \pm 0.3$ & $100 \%$ & $38 \div 9$ & $14 \%$ & $57 \%$ & Pink/pale: & $1.5 \pm$ \\
\hline $\begin{array}{l}\text { [9] PA at 30-31 min } \\
(n=17)\end{array}$ & $6.0 \pm 0.4$ & $100 \%$ & $45 \pm 5$ & $27 \%$ & $40 \%$ & Pink/pale & $1.8=$ \\
\hline $\begin{array}{l}|10| \text { PA at } 40-4 \mid \mathrm{min} \\
(\mathrm{n}=15)\end{array}$ & $5.9 \pm 0.3$ & $87 \%$ & $40 \pm 7$ & $44 \%$ & $22 \%$ & Pale & $1.1=$ \\
\hline $\begin{array}{l}\text { [11] PA at } 45-46 \mathrm{~min} \\
(\mathrm{n}=18)\end{array}$ & $5.8 \pm 0.3$ & $44 \%$ & $34 \pm 7$ & $88 \%$ & $13 \%$ & Pale & $0.8 \pm$ \\
\hline $\begin{array}{l}\text { [12) PA at } 46-47 \mathrm{~min} \\
(\mathrm{n}=14)\end{array}$ & $5.8 \pm 0.3$ & $43 \%$ & $30 \pm 7$ & $83 \%$ & $0 \%$ & Pale & $0.2 \neq$ \\
\hline $\begin{array}{l}\text { [13] PA at } 47-48 \mathrm{~min} \\
(\mathrm{n}=22)\end{array}$ & $5.9 \pm 0.6$ & $36 \%$ & $17 \pm 5$ & $100 \%$ & $0 \%$ & Pale & 0 \\
\hline $\begin{array}{l}\text { [14] PA at } 48-49 \mathrm{~min} \\
(\mathrm{n}=12)\end{array}$ & $5.9 \pm 0.6$ & $25 \%$ & $25 \pm 6$ & $100 \%$ & $0 \%$ & Pale & 0 \\
\hline $\begin{array}{l}|15| \text { PA at } 50-51 \mathrm{~min} \\
(\mathrm{n}=15)\end{array}$ & $6.0 \pm 0.6$ & $0 \%$ & - & - & - & - & - \\
\hline
\end{tabular}


Table III: Short-term effects of PA at $15^{\circ} \mathrm{C}$ monitored by direct observation at $40-60$ min following delivery.

\begin{tabular}{|c|c|c|c|c|c|c|c|}
\hline $\begin{array}{l}\text { Experimental } \\
\text { condition }\end{array}$ & $\begin{array}{l}\text { Body weight } \\
\text { (g) }\end{array}$ & Survival & $\begin{array}{l}\text { Respiratory } \\
\text { frequency }\end{array}$ & Gasping & Vocalization & $\begin{array}{l}\text { Colour of } \\
\text { the skin }\end{array}$ & $\begin{array}{l}\text { Spontaneous } \\
\text { movements }\end{array}$ \\
\hline$\underset{(n=7)}{[1] P A}$ at 2-3 min & $6.0 \pm 0.2$ & $100 \%$ & $83 \pm 2$ & $0 \%$ & $100 \%$ & Pink & $3.9 \pm 0.3$ \\
\hline $\begin{array}{l}\text { [2! PA at } 5-6 \text { min } \\
(n-5)\end{array}$ & $5.7 \pm 0.3$ & $100 \%$ & $67 \pm 5$ & $0 \%$ & $100 \%$ & Pink & $3.3 \pm 0.3$ \\
\hline $\begin{array}{l}\text { [3] PA at 10-11 min } \\
(n=7)\end{array}$ & $5.8=0.3$ & $100 \%$ & $77 \pm 4$ & $0 \%$ & $100 \%$ & Pink & $3.5 \pm 0.2$ \\
\hline $\begin{array}{l}|4| \text { PA at } 15-16 \mathrm{~min} \\
(n-6)\end{array}$ & $5.8 \pm 0.4$ & $100 \%$ & $80 \pm 0$ & $0 \%$ & $100 \%$ & Pink & $2.7 \pm 0.16$ \\
\hline $\begin{array}{l}\text { [5] PA at } 20-21 \mathrm{~min} \\
(n=-5)\end{array}$ & $5.8 \pm 0.3$ & $100 \%$ & $68 \pm 9$ & $0 \%$ & $100 \%$ & Pink & $3.0 \pm 0.57$ \\
\hline $\begin{array}{l}161 \text { PA at } 30-31 \mathrm{~min} \\
(n-7)\end{array}$ & $5.9 \pm 0.5$ & $100 \%$ & $79 \pm 1$ & $0 \%$ & $50 \%$ & Pink/pale & $2.8 \div 0.3$ \\
\hline $\begin{array}{l}\text { (7) PA at 40-41 min } \\
(n=7)\end{array}$ & $6.0 \pm 0.3$ & $100 \%$ & $61 \neq 6$ & $0 \%$ & $33 \%$ & Pink/pale & $2.2 \neq 0.16$ \\
\hline $\begin{array}{l}\text { [8] PA at } 50-51 \text { min } \\
(n=12)\end{array}$ & $5.8 \pm 0.3$ & $100 \%$ & $55 \pm 6$ & $33 \%$ & $8 \%$ & Pale & $1.1=0.33$ \\
\hline $\begin{array}{l}191 \mathrm{PA} \text { at } 60.61 \mathrm{~min} \\
(n=10)\end{array}$ & $5.7 \pm 0.3$ & $100 \%$ & $48 \pm 4$ & $50 \%$ & $0 \%$ & Pale & $0.66 \pm 0.33$ \\
\hline $\begin{array}{l}\text { [10] PA at 70-71 min } \\
(\mathrm{n}=11)\end{array}$ & $5.8 \pm 0.2$ & $100 \%$ & $50 \pm 4$ & $55 \%$ & $0 \%$ & Pale & $0.27 \pm 0.14$ \\
\hline $\begin{array}{l}\text { [11] PA at 80-81 min } \\
\qquad(\mathrm{n}=7)\end{array}$ & $6.0 \pm 0.1$ & $100 \%$ & $41 \pm 5$ & $67 \%$ & $0 \%$ & Pale & $0.2 \pm 0.17$ \\
\hline $\begin{array}{l}\text { |12| PA at 90-91 min } \\
\quad(n=5)\end{array}$ & $5.9 \pm 0.3$ & $100 \%$ & $23 \pm 5$ & $75 \%$ & $0 \%$ & Pale & 0 \\
\hline $\begin{array}{l}\text { [13] PA at 100-101 } \mathrm{min} \\
(\mathrm{n}=8)\end{array}$ & $5.9 \pm 0.3$ & $100 \%$ & $25 \pm 6$ & $88 \%$ & $0 \%$ & $\mathrm{~Pa}$ : & 0 \\
\hline $\begin{array}{l}[14] \text { PA at } 110-111] \mathrm{min} \\
(\mathrm{n}=5)\end{array}$ & $5.9 \pm 0.4$ & $60 \%$ & $24 \pm 1$ & $100 \%$ & $0 \%$ & Pale & 0 \\
\hline $\begin{array}{l}\text { |15| PA at } 120-121 \mathrm{~min} \\
(\mathrm{n}=12)\end{array}$ & $6.0 \pm 0.1$ & $54 \%$ & $14 \pm 4$ & $100 \%$ & $4 \%$ & Pale & 0 \\
\hline $\begin{array}{l}\text { [16] PA at 125-126 min } \\
(n=10)\end{array}$ & $5.6 \pm 0.2$ & $30 \%$ & $23 \pm 3$ & $100 \%$ & $0 \%$ & Pale & 0 \\
\hline $\begin{array}{l}\text { [17] PA af } 130-131 \mathrm{~min} \\
(\mathrm{n}=9)\end{array}$ & $5.5 \pm 0.0$ & $11 \%$ & $8 \pm 0.0$ & $100 \%$ & $0 \%$ & Pale & 0 \\
\hline $\begin{array}{l}{[18]+\underset{(n=7)}{P A} \text { at } 140-141 \mathrm{~min}} \\
\text {. }\end{array}$ & $6.0 \pm 0.6$ & $0 \%$ & - & - & $\cdot$ & - & - \\
\hline
\end{tabular}


Table IV: Effect of klutamate antagonises, administered to the mother one hour before hysterectomy, o the short-term effects of $\mathrm{PA}$ at $37^{\circ} \mathrm{C}$ monitored by direct observation at $40-60$ min following deliven Controls were taken from the same mother, but were not exposed to asphyxia. $*<<0.05$, compared the saline group.

\begin{tabular}{|c|c|c|c|c|c|c|c|}
\hline $\begin{array}{l}\text { Experimental } \\
\text { condition }\end{array}$ & $\begin{array}{c}\text { Body weight } \\
\text { (g) }\end{array}$ & Survival & $\begin{array}{l}\text { Respiratory } \\
\text { frequency }\end{array}$ & Gasping & Vocalization & $\begin{array}{l}\text { Colour of } \\
\text { the skin }\end{array}$ & $\begin{array}{l}\text { Spontaneous } \\
\text { movements }\end{array}$ \\
\hline \multicolumn{8}{|l|}{ SALINE } \\
\hline $\begin{array}{l}\text { Control } \\
\qquad(n-5)\end{array}$ & $6.0 \pm 0.2$ & $100 \%$ & $81 \pm 2$ & $0 \%$ & $100 \%$ & Pink & $3.9 \pm 0.1$ \\
\hline $\begin{array}{c}\text { PA at } \\
(n=78) \\
21-22\end{array}$ & $5.9 \pm 0.3$ & $3 \%$ & $16 \pm 5$ & $100 \%$ & $0 \%$ & Pale & 0 \\
\hline $\begin{array}{c}P A \\
\quad \underset{(n=10)}{22-23} \min \end{array}$ & $5.9 \pm 0.2$ & $0 \%$ & $\cdot$ & $\cdot$ & - & - & - \\
\hline \multicolumn{8}{|c|}{ MK'-80I (DIZOCILPINE) $0.2 \mathrm{mg} / \mathrm{kg}$} \\
\hline $\begin{array}{l}\text { Control } \\
\qquad(n=18)\end{array}$ & $5.8 \pm 0.3$ & $100 \%$ & $62 \pm 3$ & $7 \%$ & $40 \%$ & Pink/pale & $2.2 \pm 0.2$ \\
\hline $\begin{array}{c}\text { PA at } 21-22 \mathrm{~min} \\
(n=42)\end{array}$ & $5.7 \pm 0.3$ & $17 \%$ & $39 \pm 7$ & $60 \%$ & $20 \%$ & Pink/paie & $0.4 \pm 0.2$ \\
\hline $\begin{array}{l}\text { PA at } 22-23 \mathrm{~min} \\
\qquad(\mathrm{n}=1 i)\end{array}$ & $5.9 \pm 0.3$ & $0 \%$ & - & $\cdot$ & $\cdot$ & - & $\cdot$ \\
\hline \multicolumn{8}{|l|}{$\mathrm{NBO} \times 10 \mathrm{mg} / \mathrm{kg}$} \\
\hline $\begin{array}{l}\text { Control } \\
\qquad(n-12)\end{array}$ & $5.7 \pm 0.4$ & $100 \%$ & $62 \pm 5$ & $0 \%$ & $100 \%$ & Pink/pale & $3.1 \pm 0.3$ \\
\hline $\begin{array}{c}\mathrm{PA} \\
\underset{(n=31)}{21}-22 \mathrm{~min}\end{array}$ & $5.8 \pm 0.1$ & $13 \%$ & $17 \pm 7$ & $100 \%$ & $0 \%$ & Pale & 0 \\
\hline $\begin{array}{l}\text { PA at 22-23 min } \\
\quad(n-28)\end{array}$ & $5.7 \pm 0.2$ & $0 \%$ & - & $\cdot$ & $\cdot$ & $\cdot$ & - \\
\hline $\begin{array}{c}\text { PA at } 23-24 \mathrm{~min} \\
(\mathrm{n}=5)\end{array}$ & $5.9 \pm 0.2$ & $0 \%$ & " & - & - & $\cdot$ & - \\
\hline \multicolumn{8}{|l|}{ NBOX 20 mestes } \\
\hline $\begin{array}{l}\text { Control } \\
\qquad(n=7)\end{array}$ & $5.7 \pm 0.3$ & $100 \%$ & $73 \pm 7$ & $0 \%$ & $100 \%$ & Pink/pale & $3.5 \div 0.4$ \\
\hline $\begin{array}{l}P A \text { and } 19-20 \text { min } \\
(n-9)\end{array}$ & $5.8 \pm 0.2$ & $55 \%$ & $52 \pm \&$ & $40 \%$ & $60 \%$ & Pink/pale & $2.1 \pm 0.3$ \\
\hline $\begin{array}{c}P A=20-21 \\
(n=17)\end{array}$ & $5.8 \div 0.2$ & $24 \%$ & $32 \pm 7$ & $100 \%$ & $0 \%$ & Pale & 0 \\
\hline $\begin{array}{c}P A \\
(n=10)\end{array}$ & $5.7 \pm 0.4$ & $30 \%$ & $21 \pm 8$ & $100 \%$ & $0 \%$ & Pale & 0 \\
\hline $\begin{array}{l}P A \approx 22-23 \mathrm{~min} \\
(n=10)\end{array}$ & $5.9 \pm 0.2$ & $9 \%$ & $32 \pm 0.0$ & $100 \%$ & $0 \%$ & Pale & 0 \\
\hline $\begin{array}{c}\text { PA at } 23-24 \text { min } \\
(n=4)\end{array}$ & $5.9 \pm 0.3$ & $0 \%$ & $\cdot$ & - & - & - & $\cdot$ \\
\hline
\end{tabular}




\section{Tablo IV (coat)!}

\begin{tabular}{cccccc}
\hline $\begin{array}{l}\text { Experimental } \\
\text { condition }\end{array}$ & $\begin{array}{c}\text { Body weight } \\
(\mathrm{g})\end{array}$ & $\begin{array}{c}\text { Survival } \\
\text { fespiratory } \\
\text { frequency }\end{array}$ & Gasping & $\begin{array}{l}\text { Vocalization } \\
\text { Colour of } \\
\text { the skin }\end{array}$ & $\begin{array}{l}\text { Spontaneous } \\
\text { movements }\end{array}$ \\
\hline
\end{tabular}

\section{NBQX $30 \mathrm{me} / \mathrm{kg}$}

\begin{tabular}{|c|c|c|c|c|c|c|c|}
\hline $\begin{array}{l}\text { Control } \\
\qquad(n=7)\end{array}$ & $5.9 \neq 0.3$ & $100 \%$ & $73 \neq 7$ & $0 \%$ & $71 \%$ & Pink & $3.6 \pm 0.2$ \\
\hline $\begin{array}{l}\text { PA at } 19-20 \text { min } \\
\qquad(n=13)\end{array}$ & $5.7 \pm 0.2$ & $100 \%$ & $51 \pm 3$ & $8 \%$ & $23 \%$ & Pink/pale & $1.7 \pm 0.3$ \\
\hline $\begin{array}{c}\text { PA } \\
\quad \underset{(n=18)}{20-21} \min \end{array}$ & $5.7 \pm 0.1$ & $61 \%$ & $42 \pm 7$ & $41 \%$ & $35 \%$ & Pink/pale & $1.1 \pm 0.2$ \\
\hline$\underset{(n=20)}{P A}$ at $21-22$ min & $5.9 \pm 0.2$ & $20 \%$ & $60 \pm 10$ & $75 \%$ & $0 \%$ & Pale & 0 \\
\hline $\begin{array}{c}\text { PA at } 22.23 \text { min } \\
(n=23)\end{array}$ & $5.7 \pm 0.1$ & $17 \% *$ & $51=5$ & $100 \%$ & $0 \%$ & Pale & 0 \\
\hline $\begin{array}{c}\text { PA } \neq 23-24 \text { min } \\
(n=5)\end{array}$ & $5.8 \pm 0.2$ & $0 \%$ & - & - & - & . & - \\
\hline $\begin{array}{c}\text { PA at } 30-31 \text { min } \\
(n=3)\end{array}$ & $5.9 \pm 0.2$ & $0 \%$ & - & . & - & - & - \\
\hline
\end{tabular}

\section{NBQX $30 \mathrm{mg} / \mathrm{kg}+$ MK-801 $0.2 \mathrm{mg} / \mathrm{kg}$}

\begin{tabular}{|c|c|c|c|c|c|c|c|}
\hline $\begin{array}{l}\text { Control } \\
\qquad(n=10)\end{array}$ & $6.0 \pm 0.5$ & $100 \%$ & $63 \pm 3$ & $0 \%$ & $90 \%$ & Pink & $4.0 \pm 0.4$ \\
\hline $\begin{array}{c}\text { PA at } 19-20 \mathrm{~min} \\
(\mathrm{n}=3)\end{array}$ & $5.8 \pm 0.1$ & $100 \%$ & $36 \pm 3$ & $67 \%$ & $0 \%$ & Pink & $3.2 \pm 0.4$ \\
\hline 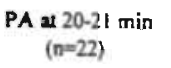 & $5.8 \pm 0.3$ & $41 \%$ & $22 \pm 2$ & $94 \%$ & $0 \%$ & Pale & $0.5 \pm 1.0$ \\
\hline $\begin{array}{l}\text { PA at } 21-22 \mathrm{~min} \\
\quad(n=20)\end{array}$ & $5.9 \neq 0.26$ & $36 \%$ & $12 \pm 2$ & $100 \%$ & $17 \%$ & Pink/pale & 0 \\
\hline $\begin{array}{c}\mathrm{PA} \text { at } 22-23 \mathrm{~min} \\
(\mathrm{n}=23)\end{array}$ & $5.7 \pm 0.1$ & $17 \%$ & $9 \pm 2$ & $100 \%$ & $0 \%$ & Pale & 0 \\
\hline $\begin{array}{l}P A \\
\quad(n=5)\end{array}$ & $5.8 \pm 0.5$ & $20 \%$ & $8 \pm 0.0$ & $100 \%$ & $0 \%$ & Pale & 0 \\
\hline
\end{tabular}




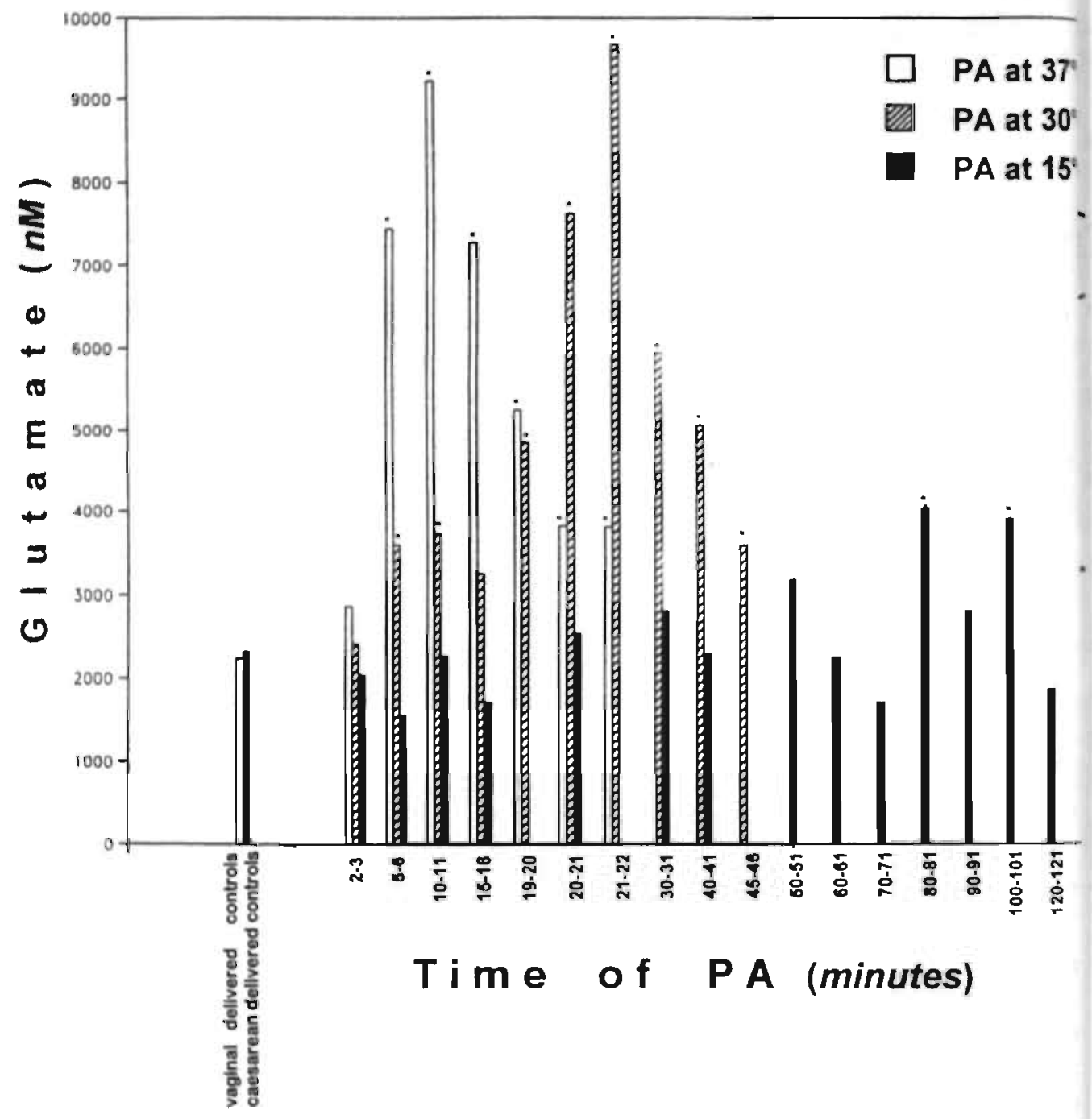

Fig 7: Short-tarm effects of $P A$ at $37^{\circ} \mathrm{C}, 30^{\circ} \mathrm{C}$ and $15^{\circ} \mathrm{C}$ on subcutaneous levels of glutamate (G/u) measured at $\mathbf{6 0 . 8 0}$ min following delivery of vaginal and caesarean-delivered controls at different asphyctic periods of time in pups. (J) $P<0.05$ for the two tailed test, compared with the ceesarean-delivered group $(N=4-26)$ 


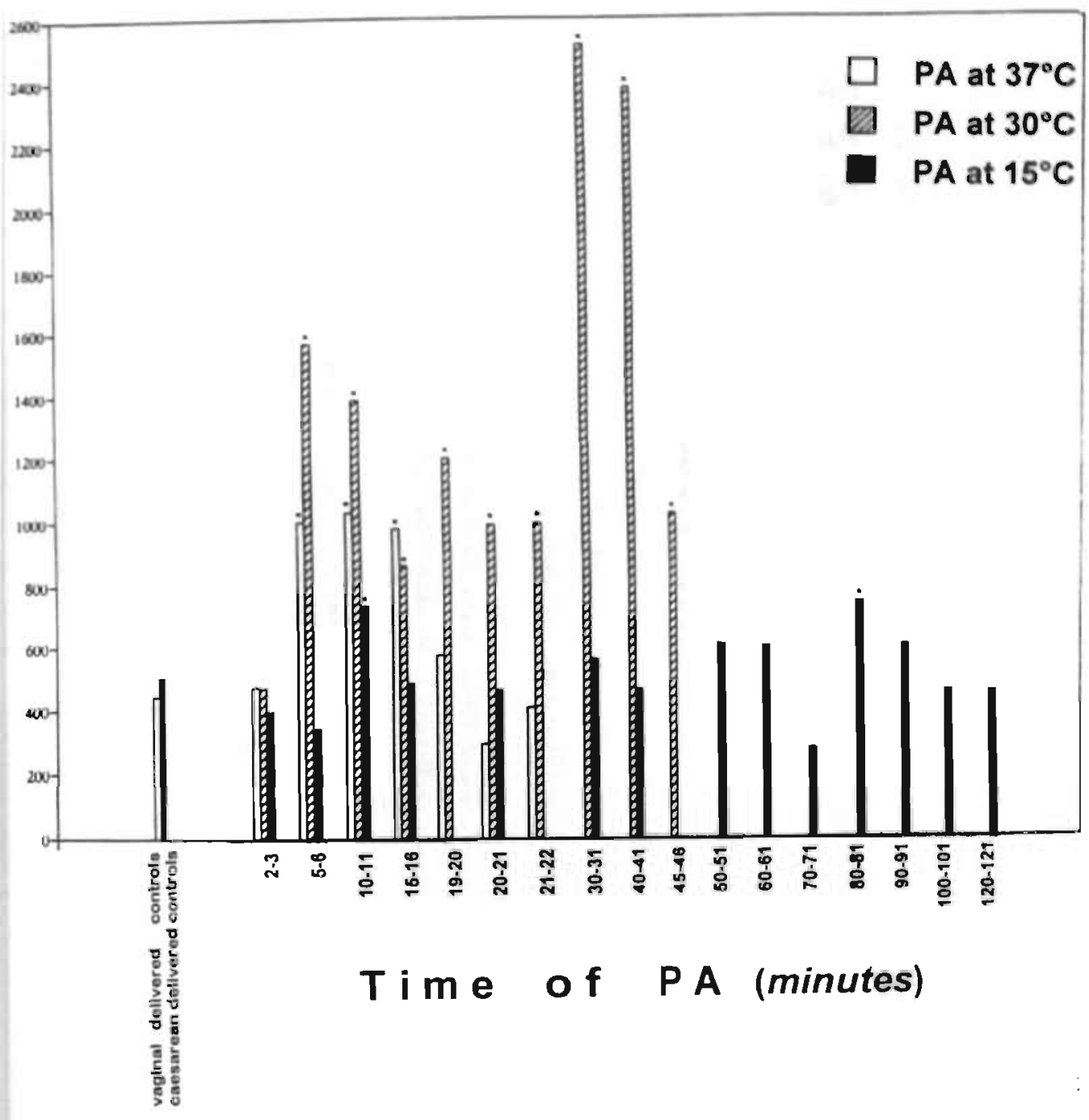

Fig 8: Short-term effects of $\mathrm{PA}$ at $37^{\circ} \mathrm{C}, 30^{\circ} \mathrm{C}$ and $15^{\circ} \mathrm{C}$ on subcutaneous levels of aspartate (Asp) measured at 60.80 min following delivery of vaginal and caesarean-delivered controls at different asphyetic periods of time in pups. (.) $P<0.05$ for the two tailed test, compared with the caesarean-delivered group $(\mathrm{N}=4-26)$ 


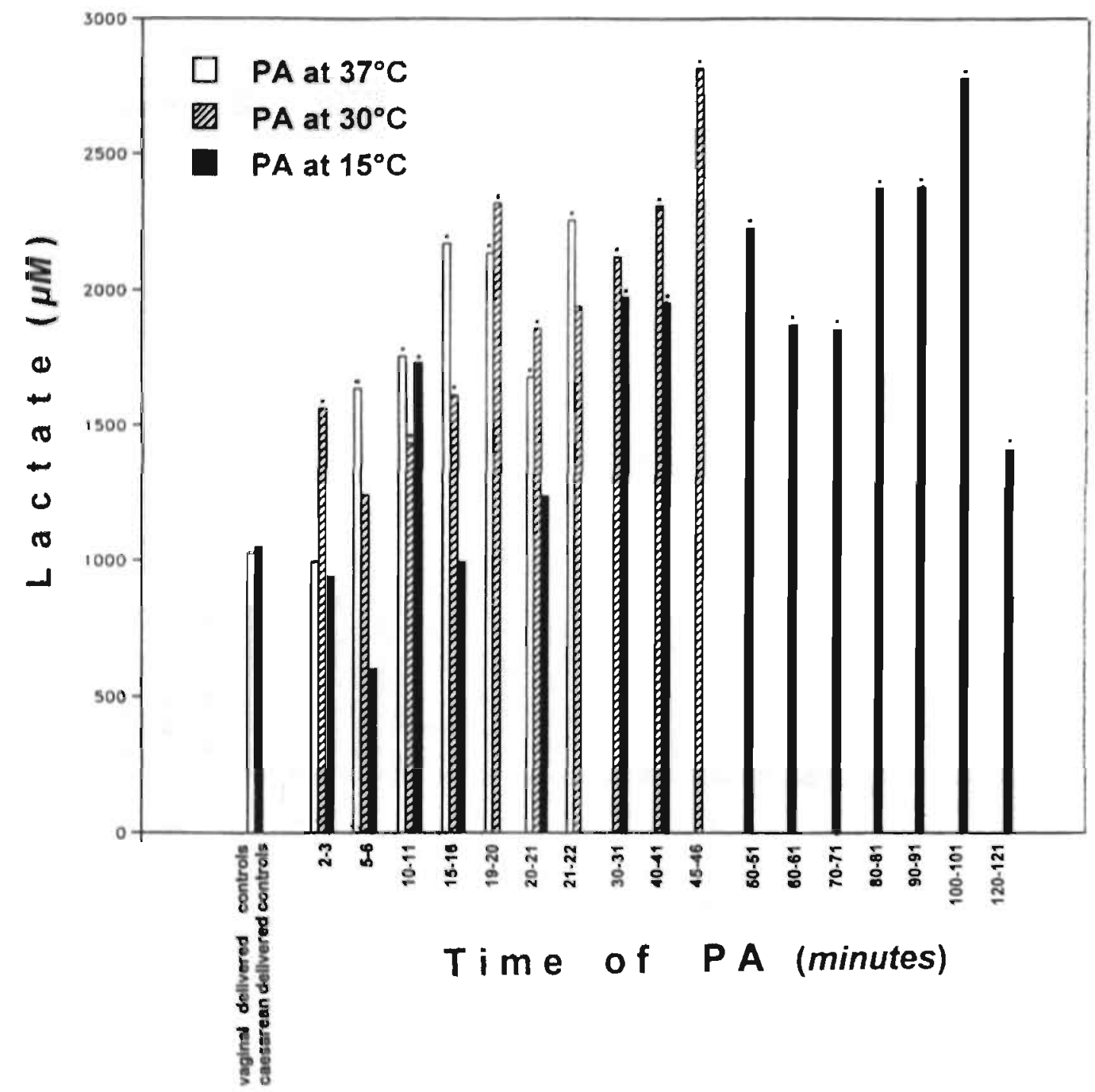

Fig 9: Shory-ferm effects of $\mathrm{PA}$ at $37^{\circ} \mathrm{C}, 30^{\circ} \mathrm{C}$ and $15^{\circ} \mathrm{C}$ on subcutuncous lovels of lactore (Lac) measured at 60.80 min following delivery of vaginal and csesarean-delivered controls at different asphyctic periods of time in pups. (J) $P<0.05$ for the two tailed test, compared with the cuesaraan-delivered group $(N=4.26)$ 


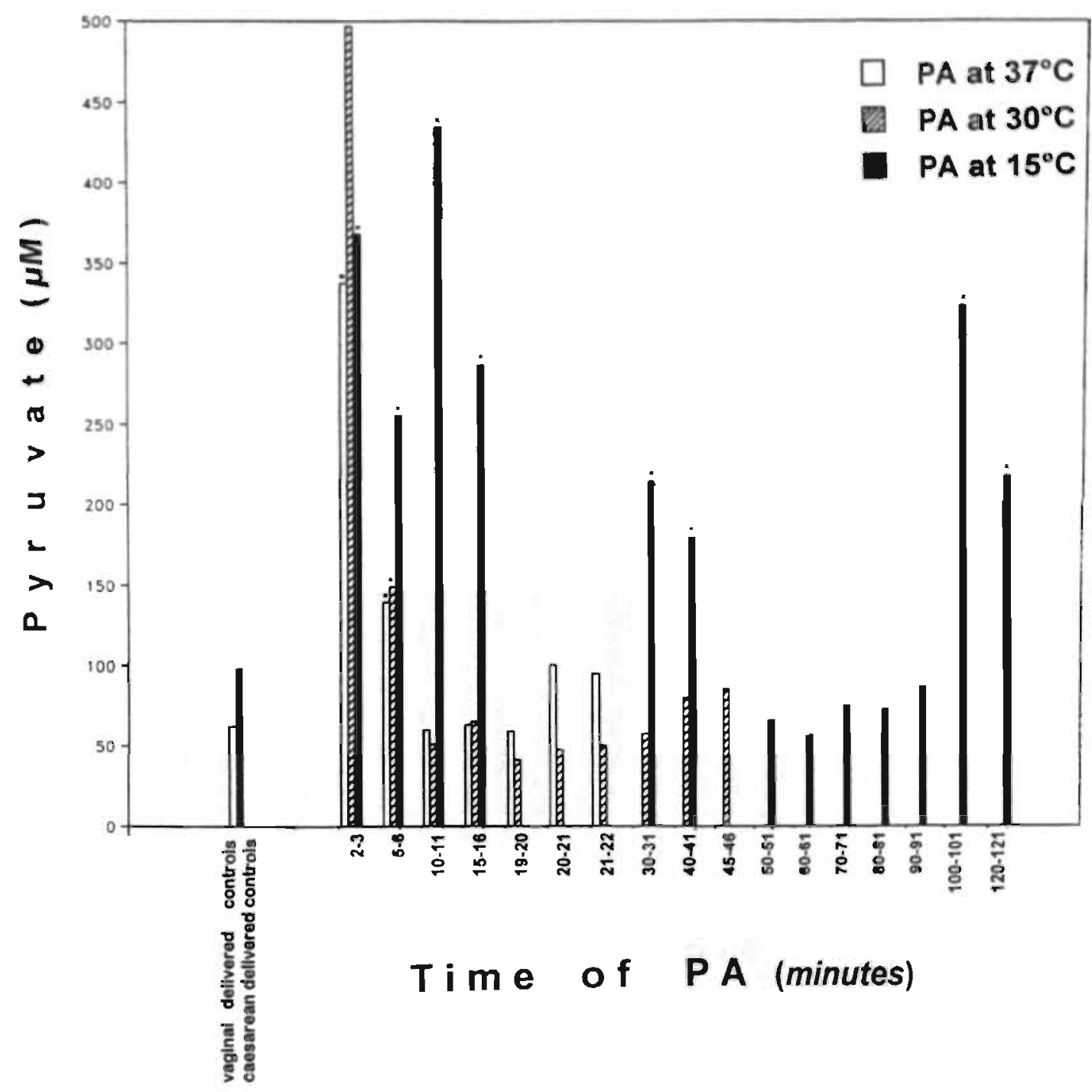

Fig 10: Short-term effects of $P A$ at $37^{\circ} \mathrm{C}, 30^{\circ} \mathrm{C}$ and $15^{\circ} \mathrm{C}$ on subcutaneous levels of pyruvate (Pyr) measured at 60-80 min following delivery of vaginal and caesarean-delivered controls at different asphyctic periods of time in pups. (.) $P<0.05$ for the two tailed test compared with the caesarean-delivered group $(N=4-26)$ 


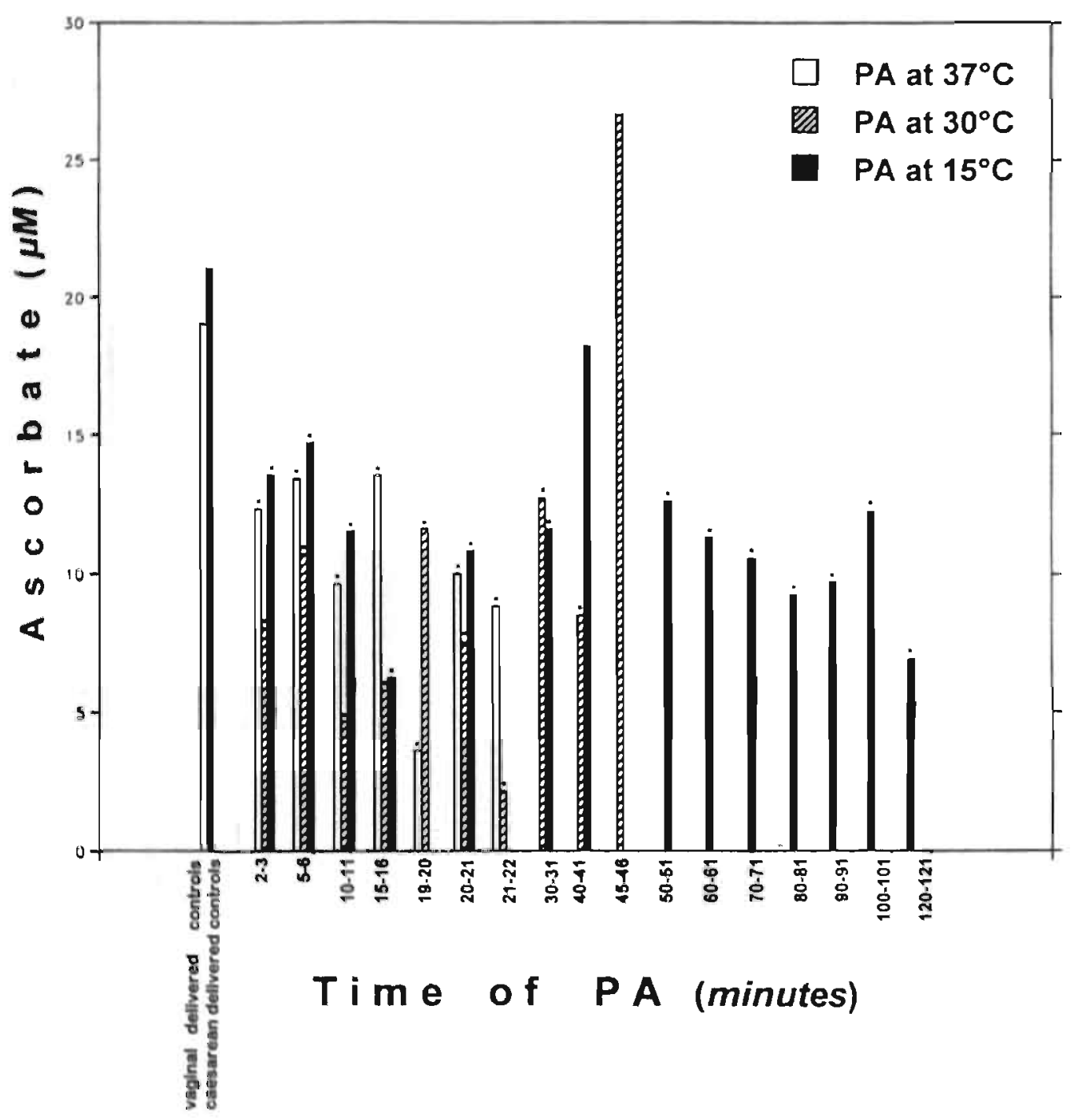

Fig 11: Short-term offects of $P A$ at $37^{\circ} \mathrm{C}, 30^{\circ} \mathrm{C}$ and $15^{\circ} \mathrm{C}$ on subcutaneous levels of ascorta. to (Asc) measured at $60.80 \mathrm{~min}$ following delivery of vaginal and caesarean-delivered controls at different asphyctic periods of time in pups. (1) $P<0.05$ for tho two tailed test compared with the caesarean-delivered group $(N=4-26)$ 
Perinatal Asphyxio $\quad 0-0$ at $37^{\circ} \mathrm{C}$

o- 0 . Shilt ot $5 \mathrm{~min}$

- - Shift ot $10 \mathrm{~min}$

- Shift at $15 \mathrm{~min}$

- - Shift ot $19 \mathrm{~min}$

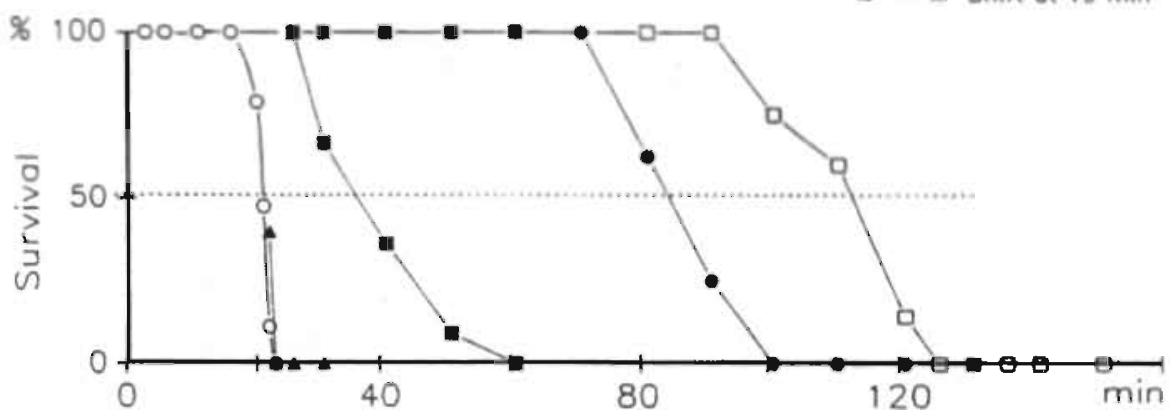

Fig 12 : Percentage of survival at different PA periods of time when shifting temperature from $37^{\circ} \mathrm{C}$ to $15^{\circ} \mathrm{C}$ was performed at $5,10,15$ and $19 \mathrm{~min}$ from the starting of asphyxia. 


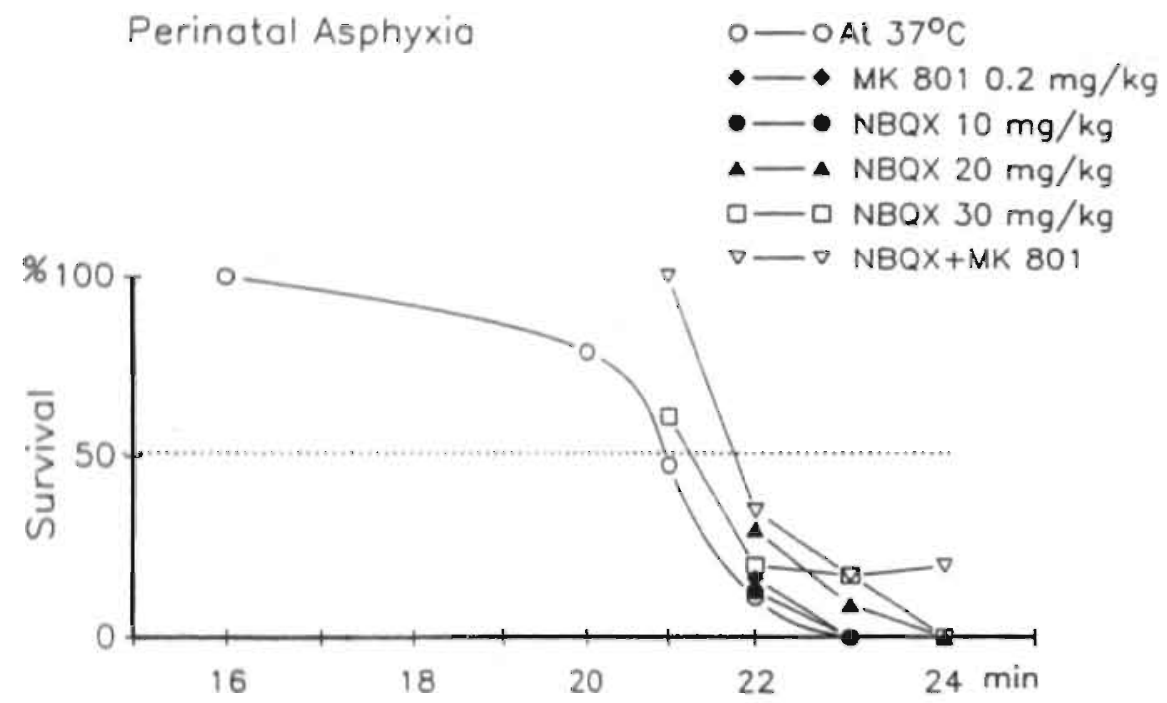

Fig 13: Percentage of pups that survived the differeat PA periods of time at $37^{\circ} \mathrm{C}$ when glute. mato antagonists wore administored intraporitoneally to the mother one hour prior to hysturectomy. 


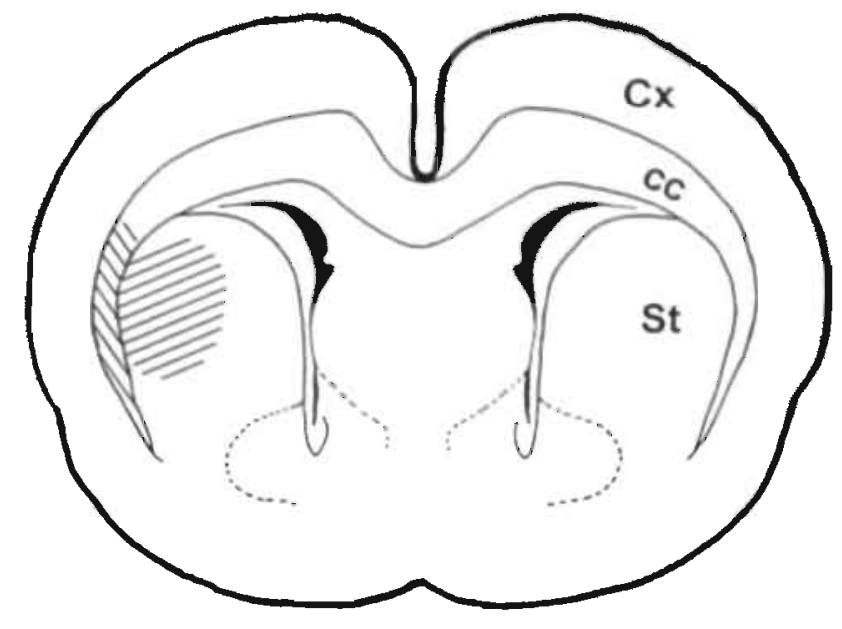

Fig 14 : NADPH-d positive areas (shadow) in control and in asphyctic newborn rats. Abbreviations: Cx: cerebral cortex; St: striatum; CC: corpus callosum 
46
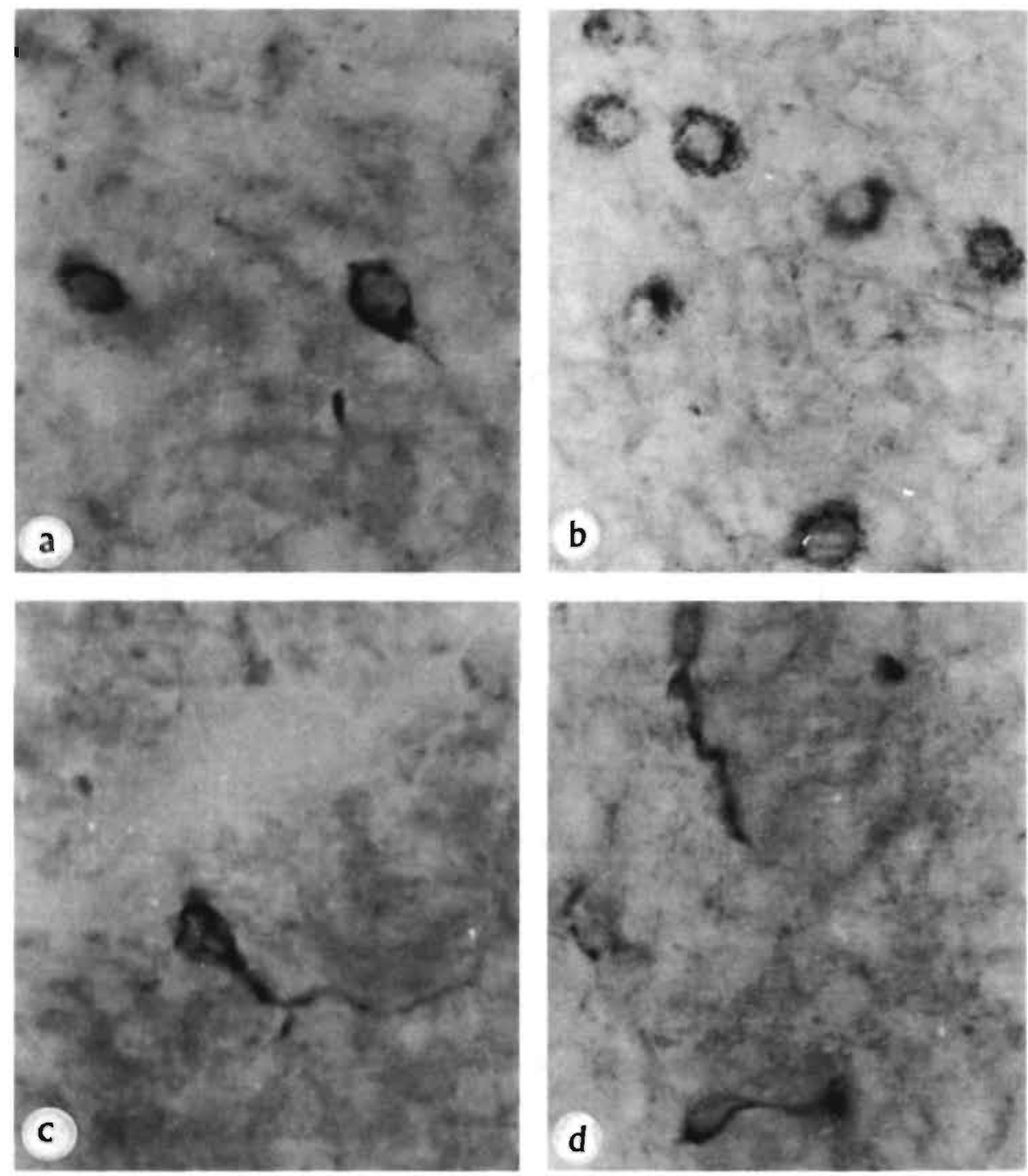

Fig 15 : Photomicrographs of NADPH-d positive neurons located in the lateral zone of the rostral striatum (900x), a control; b : PA (100 mint + hypothermia $\left(15^{\circ} \mathrm{C}\right)$, c and d : severs PA ( $220 \mathrm{~min} / 37^{\circ} \mathrm{C}$. Nots the cell proceesses in severs PA. 

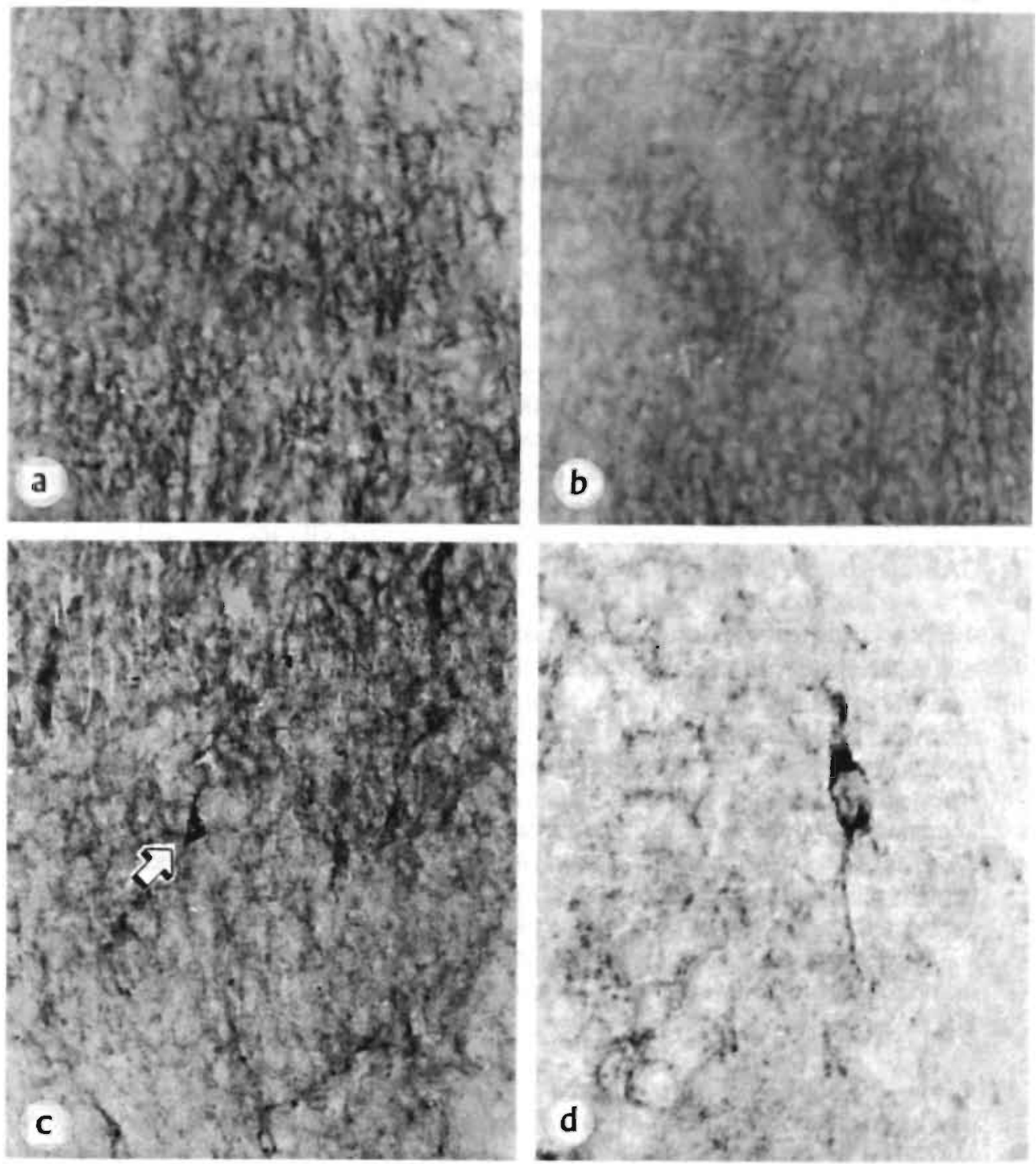

Fig 16 : Photomicrographs of NADPH-d positive neurons located in the cerebral cortex (150x). $a$ : control; b : PA (100 min) + hypothormia $\left(15^{\circ} \mathrm{C}\right)$, $c$ and d : sovere PA $\left(220 \mathrm{~min} / 37^{\circ} \mathrm{C}\right)$. Noto the coll proceesses in sovere PA (900x). Note positive staining in some cortical nourons of animals subjected to sovero PA. 


\subsection{LONG-TERM EFFECTS OF PERINATAL ASPHYXIA}

4.3.1 Intracerebral microdialysis: After 6 months, rats that had suffered PA and controls, were implanted with two microdialysis probes, one in striatum and the other in substantla nigra. Monoamines and aminoacids were monitored under basal and D-amphetamine-stlmulated conditions (see Tables VVII).

Significant changes in monoamines, GABA and Glu were observed in rats exposed to subsevere and severe asphyxia. Striatal extracellular DA levels were signlficantly increased in animals exposed to subsevere $\left(19-20 \mathrm{~min}\right.$, at $\left.37^{\circ} \mathrm{C}\right)$ asphyxia (approximately twofold), although the effect of D-amphetamine on extracellular DA levels was slgnificantly decreased (Fig. 17; Table VI). Striatal basal levels of Glu decreased. No slgniflcant effects were observed in Asp levels. Extracellular GABA levels In substantla nigra were $50 \%$ decreased (Table VI). In animals with severe asphyxla $\left(220 \mathrm{~min}\right.$, at $\left.37^{\circ} \mathrm{C}\right)$, a decrease in striatal DA levels under basal $(\approx 70 \%)$ and D-amphetamine stimulation $(\approx 50 \%$ compared to controls) (Flg. 17; Table VII) as well as a decrease in striatal Glu and Asp and nigral GABA levels were observed (Table VII).

\subsubsection{Immunocytochemistry and basal ganglia in 6 months} oldl asphyctic and control rats: In 6 months old rats that suffered subsevere and severe $\mathrm{PA}$, an astrogllal hypertrophy in striatum (Flg $18 \mathrm{c}$ ), substantia nlgra (Flg 19b) and cortex Illustrated by the enlargement and tortuosity of astrocytes was observed. These findings were compatible with the typical "astroglial reactlon" also evident in the perlvascular and limitant glla. The astroglial reaction Immunostained wlth GFAP was more intense in those animals exposed to severe PA. The staining to GFAP In substantia nlgra and strlatum of the hypothermictreated anlmals (exposed to PA at $15^{\circ} \mathrm{C}$ ) for 20-21 and 100-101 minute periods were simllar to that of the controls (Figs. $18 \mathrm{~b}$ and $19 \mathrm{c}$ ).

A great increase in immunostaining to NF was found in those animals that suffered severe PA. However, thls was the case only in those of $230 \mathrm{kD}$ (see Flg. 20).

\subsubsection{NADPH-d histochemical staining in 6 months old} asphyctic, control and hypothermic-treated rats: Throughout, NADPH-d staining in strlatum transverse sectlons of 6 months old rats showed unlformly distributed medlum-slzed neurons. Subsevere and severe PA groups presented an increase in soma size accompanled by an enlargement of processes, with evident tortuous dendritc arborization typical of the so-called neuronal cytomegaly (Mischel, 1995), when compared wlth control group and remaining PA groups at $37^{\circ} \mathrm{C}$ as well as 20 and 100 minutes $\mathrm{PA}$ at $15^{\circ} \mathrm{C}$ (compare Figs. $21 \mathrm{a}$ c). Labelled cell area and cell perimeter were measured by Image analysis in each experimental group. Both strlatal cell area and cell perimeter of rats exposed to subsevere and severe PA showed a highly signlficant cytomegaly $(p<0.001)$ In 
comparison with control, slight, moderate $\mathrm{PA}$ and $\mathrm{PA}$ at $15^{\circ} \mathrm{C}$ groups for 20 and 100 minutes (see Figs. 22a-b).

F-shape measurement of the neurons falled to disclose statistical differences between striatal neurons in all studied groups (see Figs. 22c and 22f).

Mean cell count per field with a $40 X$ objective was $5 \pm 1$ in striatum and $4 \pm 1$ in cerebral cortex, lacking significant intergroup differences.

Likewise, in rats subjected to subsevere and severe PA, NADPH-d+ neurons In cerebral cortex sections, including medium-sized ones belonging to local circult neurons, displayed morphological changes that presented similar characteristics to those of cytomegalic cells observed in strlatum (compare Flgs. $21 \mathrm{~d}-\mathrm{e}$ ). Anlmals suffering 20 and 100 minutes of $\mathrm{PA}$ at $15^{\circ} \mathrm{C}$ showed a similar stalning pattern to that of controls, slight and moderate PA groups (compare Flgs. 21 if and $21 \mathrm{~d}$ )

Cortical cell area and perimeter increased significantly in rats exposed to subsevere and severe PA $(\mathrm{p}<0.001)$ compared with control, slight, moderate PA and PA at $15^{\circ} \mathrm{C}$-treated animals for 20 and 100 minutes (see Flgs 22d-e).

After 6 months, those animals subjected to 20 or 100 minutes $\mathrm{PA}$ at $15^{\circ} \mathrm{C}$ disclosed typical NADPH-d(+) neurons in the corpus callosum (see Flgs 23b-c).

\subsubsection{Cresyl violet staining in the striatum and cortex}

Subsevere and severe PA (normothermic ischemla) resulted In a loss of neurons in medial, posterior, ventral and dorsal sector of the striatum $(P 0.001)$. Hypothermia $\left(20 \mathrm{~min}\right.$ and $100 \mathrm{mln}$ at $\left.15^{\circ} \mathrm{C}\right)$ reduced neuronal loss $(P 0.001)$. In the other groups $(5,10$ and $15 \mathrm{~min})$, no differences with controls were observed. When comparing different regions of the striatum (ventral, dorsal, lateral, medial) no significant differences were found $(P<0.001)$.

Subsevere and severe PA also resulted in a severe loss of neurons in medlal and lateral neocortex with statistical difference $(P<0.001)$. Hypothermla $(20$ min and $100 \mathrm{~min}$ at $\left.15^{\circ} \mathrm{C}\right)$ attenuated neuronal loss significantly $(\rho<0.001)$. When comparing different sectors of the neocortex (lateral and medlal) no signiffcant differences were found $(p<0.001)$. 


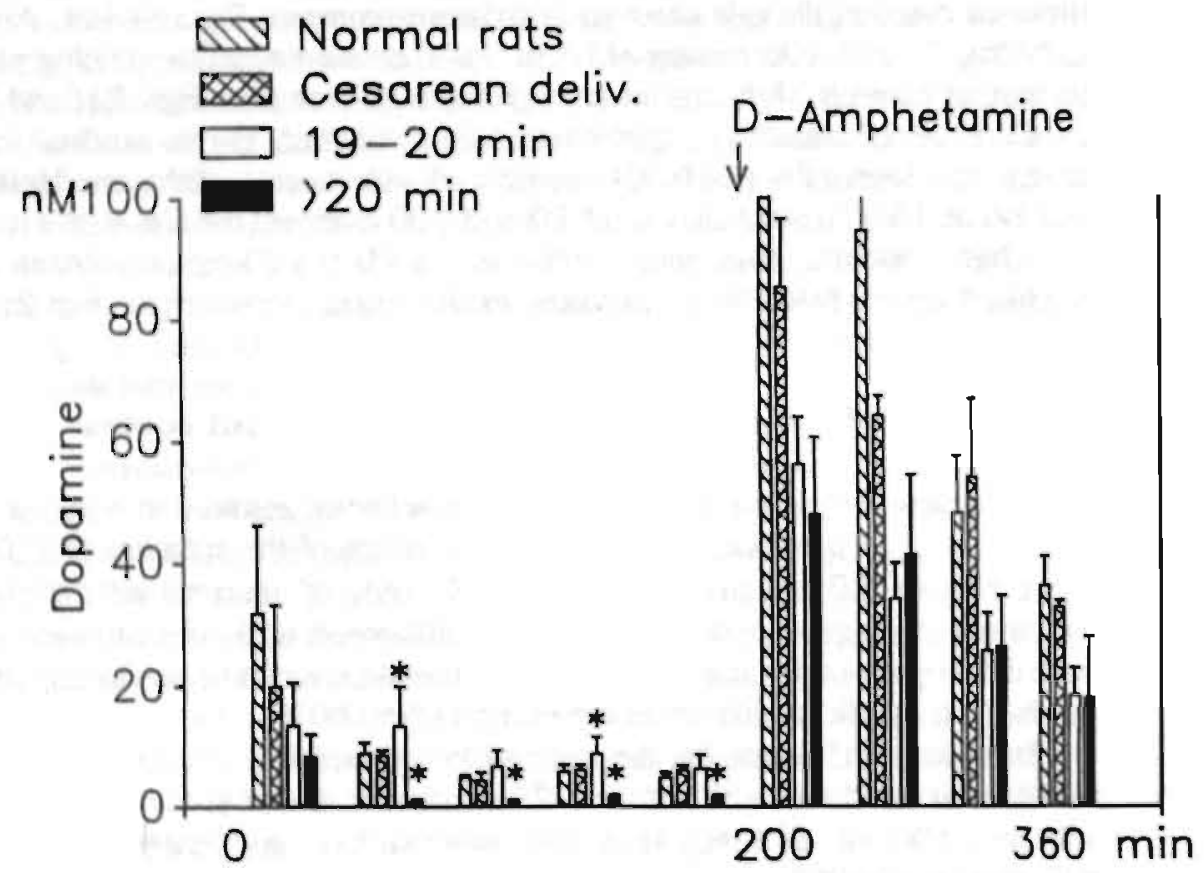

Fig 17: Effect of subsevere $\left(19.20 \mathrm{~min} / 37^{\circ} \mathrm{C}\right)$ and severe $\left(220 \mathrm{~min} / 37^{\circ} \mathrm{C}\right) \mathrm{PA}$ on extracellular striatal dopamine levels measured 6 mooths after delivery. Microdialysis probes $14-\mathrm{mm}$ length) perfused with a modified CSF solution were implanted in the striatum of: (I) yaginal. deliversd controls (hatched columas, $a=8$ ), (2) cassarean-selivered cootrols (cross-hatched columns, $n=81$, (3) subsevero PA (opes columns, $a=9$ ) and (4) sovero PA (filled coluns, $n=8$ ) rats. At a 200 min poriod of time following aicrodia/ysis implastation, a dose of D-eaphetamine (2 mg/kg s.c.) was administered. Dopamihe was assayed in $20 \mu \mathrm{l}$ samples using HPL.C. EC. Vertical lines show SEM $\bullet P<0.05$ for the two tailed test (Mann-Withney U-test corroctod by the Bonferroni's procodurel. 
Table V: Long-term effects ( 6 months after delivery) on monoamine, aminoadids and metabolic products levels monitored under basal (160.200 min period of time following microdialisys implantation) and D-amphetamine-stimulated (2 mg/kg s.c.) (200-240 min period) conditions in striatum and substantia nigra of caesarean delivered control rats.

Basal (nM)

\section{Striatum}

Control $(n=15-22)$

Dopamine

DOPAC

HVA

5-HIAA

GABA

Glutamate

Aspartate

Lactate

Pyruvate

Ascorbate

\section{Substantia nigra}

Control $(n=16-24)$

Dopamine

DOPAC

HVA

5-HIAA

GABA

Glutamate

Asparate

Lactate

Pyruvate

Ascorbate

$$
\begin{aligned}
4.2 & \pm 1 \\
1175 & \pm 115 \\
1052 & \pm 154 \\
3022 & \pm 321 \\
22 & \pm 3 \\
1203 & \pm 281 \\
133 & \pm 30 \\
122 & \pm 41 \\
12 & \pm 2 \\
4 & \pm 0.7
\end{aligned}
$$

$$
\begin{aligned}
72.4 & \pm 9 \\
779 & \pm 95 \\
923 & \pm 133 \\
2694 & \pm 266 \\
27 & \pm 5 \\
1322 & \pm 321 \\
101 & \pm 33 \\
152 & \pm 38 \\
15 & \pm 2 \\
4 & \pm 0.6
\end{aligned}
$$

(106\%)

$$
\begin{aligned}
0.9 & \pm 0.1 \\
14 & \pm 2 \\
38 & \pm 8 \\
496 & \pm 131 \\
19 & \pm 3 \\
788 & \pm 201 \\
91 & \pm 20 \\
88 & \pm 9 \\
7 & \pm 0.6 \\
3.7 & \pm 0.7
\end{aligned}
$$

$80 \div 10$

$95 \pm 14$

$8 \pm 1$

$3.6 \pm 0.8$ 
Table VI: Long-term effects ( 6 months after delivery) on monoamines and aminoacids levels monitored under basal (160-200 min period of time following mlerodialisys implantation) and D-amphetaminestimulated (2 mg/kg s.c.) (200-240 min period of time) conditions in striatum and substantia nigra of subsevere asphycuic $\left(19-20 \mathrm{~min}\right.$ of $\left.\mathrm{PN} 37^{\circ} \mathrm{C}\right)$ rats.

\section{(A) Striatum}

Subsevere PA $(n=7)$

Dopamine

DOPAC

HVA

5.HIAA

GABA

Glutanate

Aspartate

Acetylcholine

Choline.

$$
\begin{aligned}
6.1 & \pm 1.7 * \\
1047 & \pm 177 \\
1417 & \pm 186 \\
406 & \pm 25 \\
28 & \pm 3 \\
575 & \pm 161 * \\
100 & \pm 20 \\
255 & \pm 56 \\
799 & \pm 194
\end{aligned}
$$$$
65.3 \pm 8 \text { = }
$$$$
436 \pm 115
$$$$
1086 \pm 99
$$$$
395 \pm 36
$$$$
66 \pm 18
$$$$
1360 \pm 500
$$$$
140 \pm 50
$$$$
467 \pm 110
$$$$
722 \pm 172
$$

$\begin{array}{lcc}\text { (A) Substantia nigra } & & \\ \text { Subsevere PA }(n=7) & & \\ \text { Doparnine } & 0.74 \pm 0.1 & 1.8 \pm 0.3 \\ \text { DOPAC } & 14 \pm 4.7 & 12 \pm 4.4 \\ \text { HVA } & 36 \pm 5.4 & 40 \pm 6 \\ \text { S-HIAA } & 175 \pm 24 & 629 \pm 25 \\ \text { GABA } & 11.5 \pm 2.5^{*} & 12 \pm 3.4^{*} \\ \text { Glutamate } & 830 \pm 370 & 720 \pm 240 \\ \text { Aspartate } & 100 \pm 20 & 70 \pm 120 \\ \text { Acetylcholine } & 11 \pm 2.5 & 20 \pm 6 \\ \text { Choline } & 389 \pm 56 & 409 \pm 184\end{array}$

- $=P<0.05$ compared to the corresponding values observed in the controls. 
Table VII: Long-term effects (6 months after dellvery) on monoamine, aminoacids and metabolic products levels monitored under basal (160-200 min period ot time following microdiallsys implantation) and D-amphetamine-stimulated ( $2 \mathrm{mg} / \mathrm{kg} \mathrm{s.c.}$ ) (200-240 min period of time) conditions int the striatum and substantia nigra of severe asphyctic ( $220 \mathrm{~min}$ of $\mathrm{PA}$ at $37^{\circ} \mathrm{C}$ ) rats.

\section{Basal (nM)}

\section{Striatum}

Severe PA $(n=4-8)$

Dopamine

DOPAC

HVA

5-HIAA

GABA

Glutamate

Aspartate

Lactate

Pyruvate

Ascorbate

\section{Substantia nigra}

Severe PA $(n=4-8)$

Dopamine

DOPAC

HVA

5-HIAA

GABA

Glutamate

Aspartate

Lactate

Pyruvate

Ascorbate

$$
\begin{aligned}
1.6 & \pm 0.44^{*} \\
1239 & \pm 175 \\
773 & \pm 88 \\
926 & \pm 67^{*} \\
21 & \pm 3 \\
230 & \pm 40^{*} \\
61 & \pm 10^{*} \\
120 & \pm 11.5 \\
7 & \pm 0.2 \\
8 & \pm 0.8
\end{aligned}
$$

D-Amphetamine (nM)

$\%$

$$
\begin{aligned}
48 & \pm 13^{*} \\
819 & \pm 129 \\
694 & \pm 77.4 \\
880 & \pm 67^{*} \\
26 & \pm 1.75 \\
222 & \pm 50^{*} \\
240 & \pm 130^{* *} \\
185 & \pm 19 \\
9 & \pm 0.4 \\
7.3 & \pm 0.6
\end{aligned}
$$

(2951\%)

(66\%)

(90\%)

$(122 \%)$

(95\%)

(91\%)

(1!9\%)

(91\%)

* $=P<0.05$ compared to the corresponding values observed in the controls. 

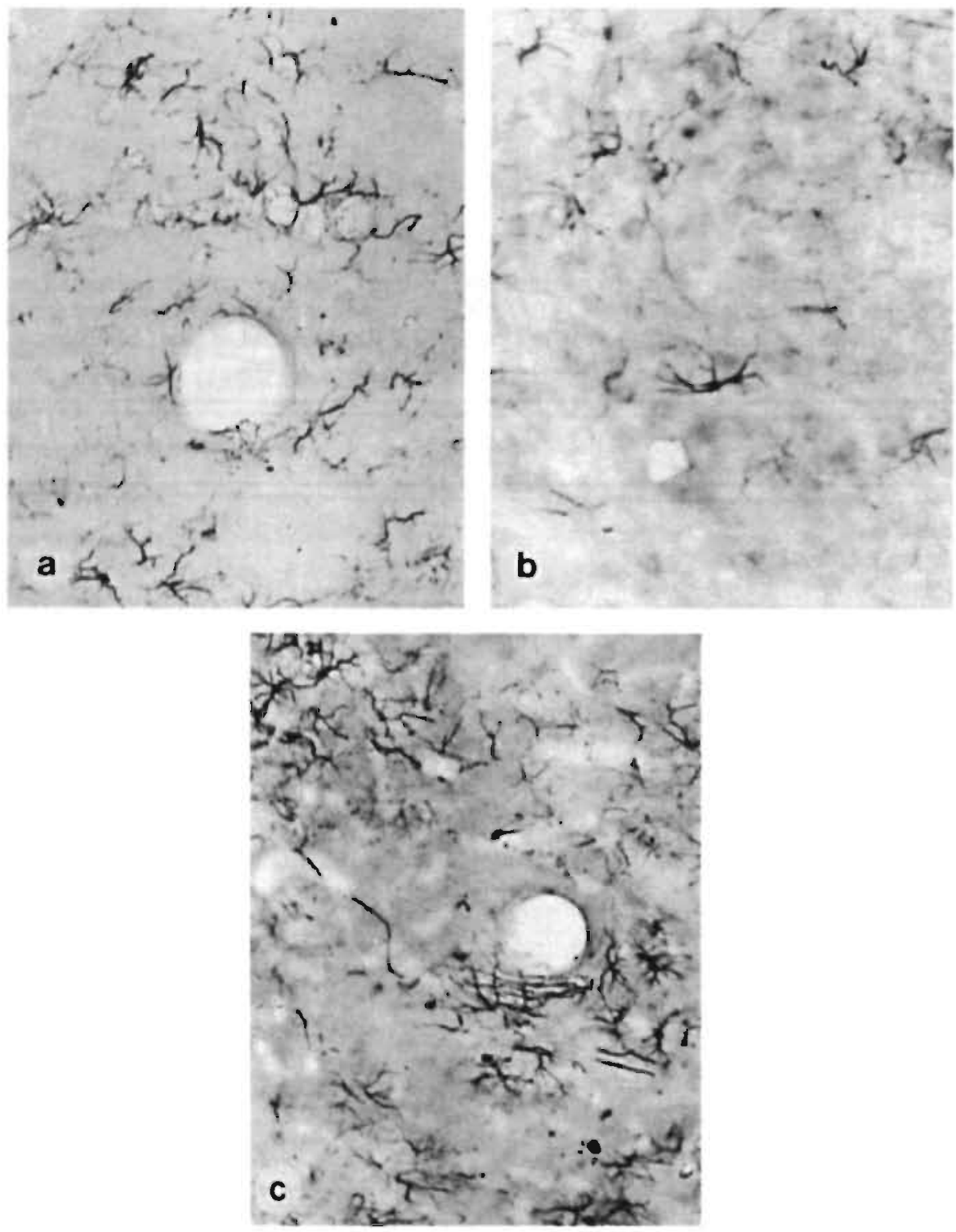

Flg 18 : Photomicrographs of stristua immunstainad against GFAP 6 months after deliver

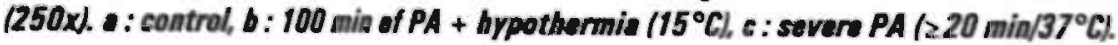




\section{a}
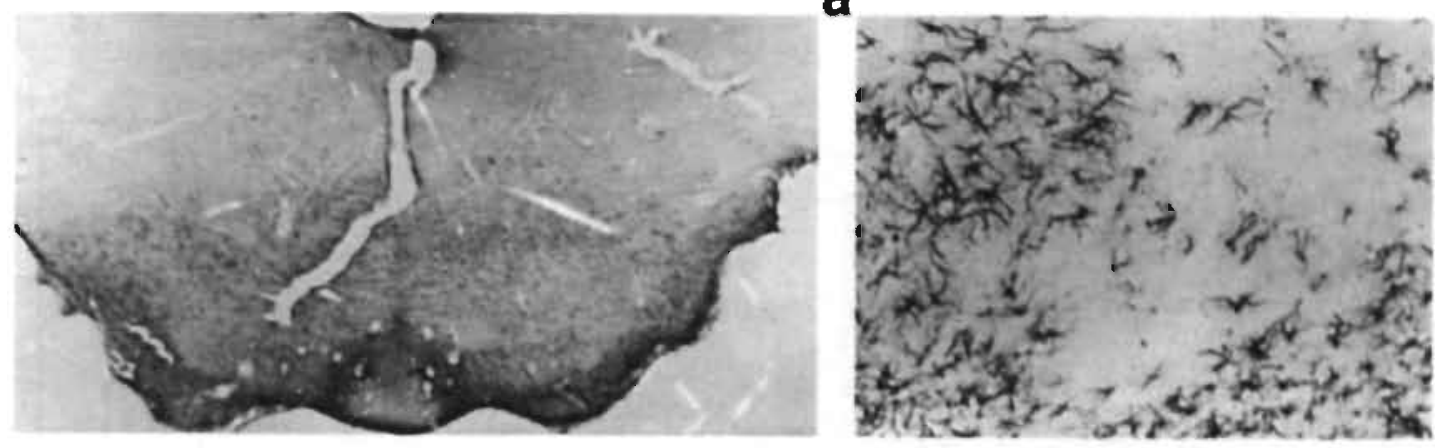

b
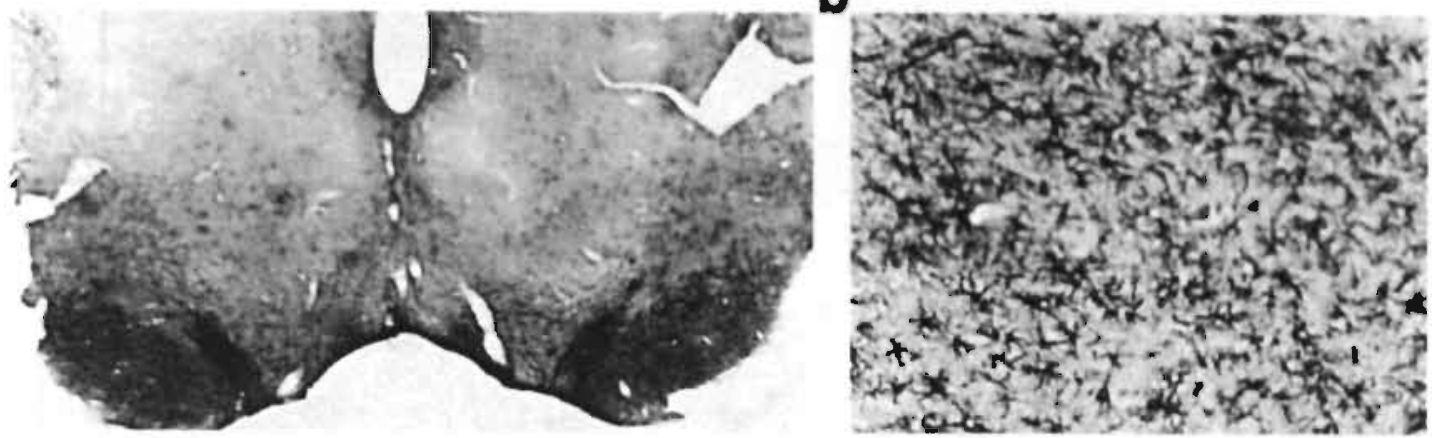

C

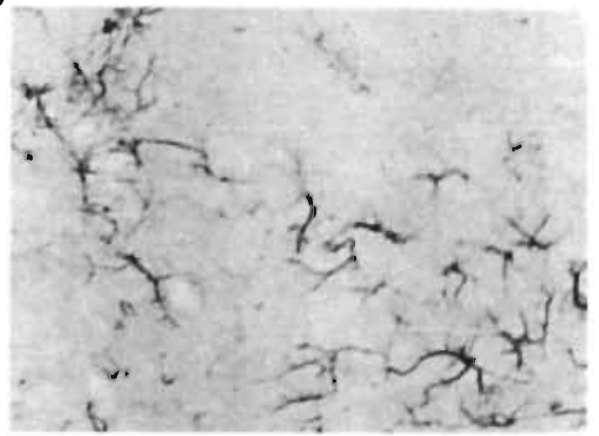

Fig 19 : Photomicrographs of substantia nigra immunstalned against GFAP 6 months after delivery $(250 \mathrm{x})$. a : control, b : severe PA $\left(220 \mathrm{~min} / 37^{\circ} \mathrm{C}\right)$, and c: 100 min of PA + hypothermla $\left(15^{\circ} \mathrm{C}\right)(250 x)$. 

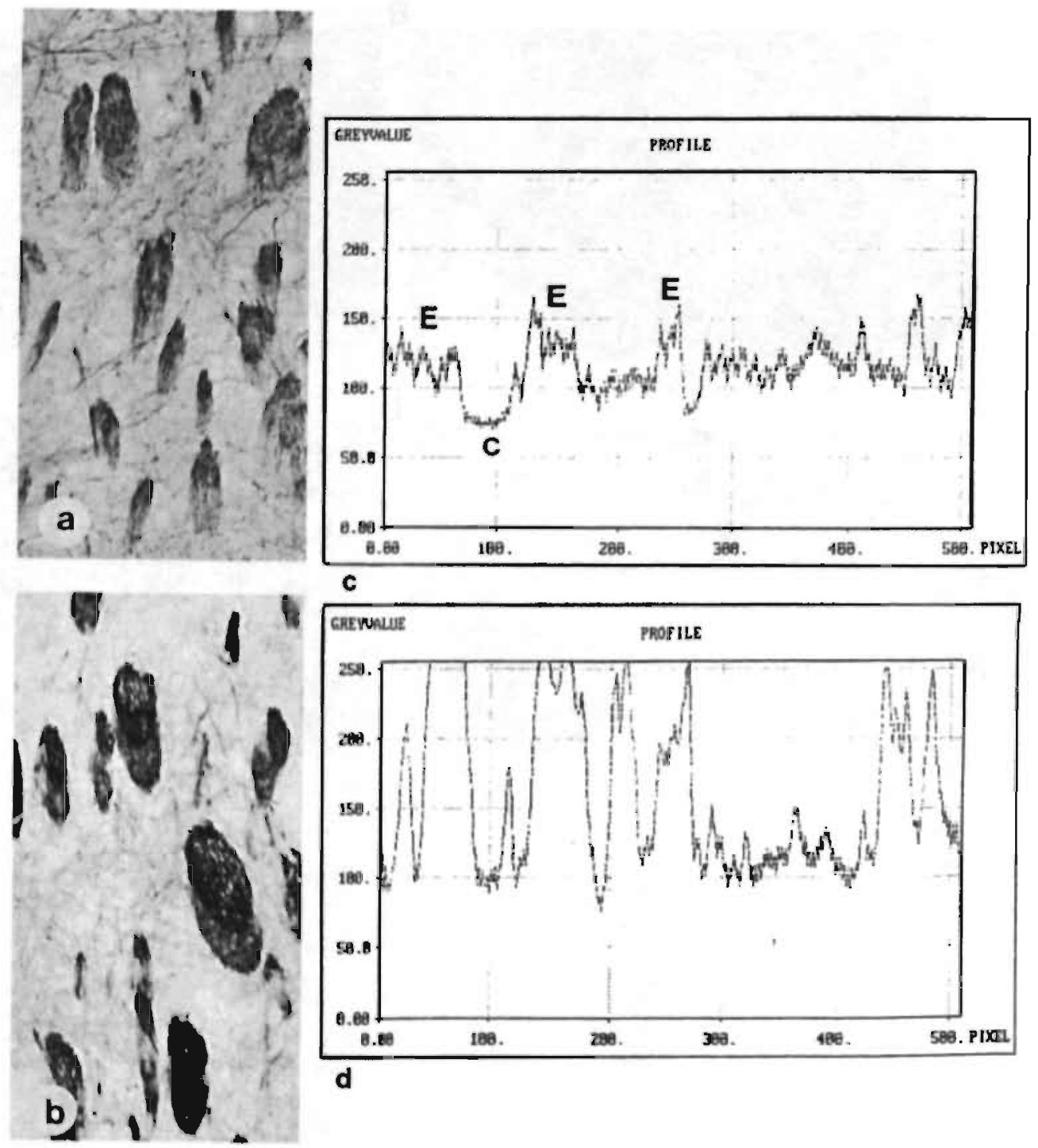

Fig 20: Photomicrographs of $230 \mathrm{kD}$ NFimmunostaining in striatum of (a) control (300x), and (b) sovere PA (300x) and their correspondent grepvalue profile cbtained whon a compurtarized horizontal line crosses several striosomes $(E)$ in $(c)$ control striatum stained to $230 \mathrm{kD}$ and (d) sover PA striatum stained to $230 \mathrm{kD}$. C ceapilar. Note the increase in immunostaining sho. wed by increase in groyvalue profile in (d). 

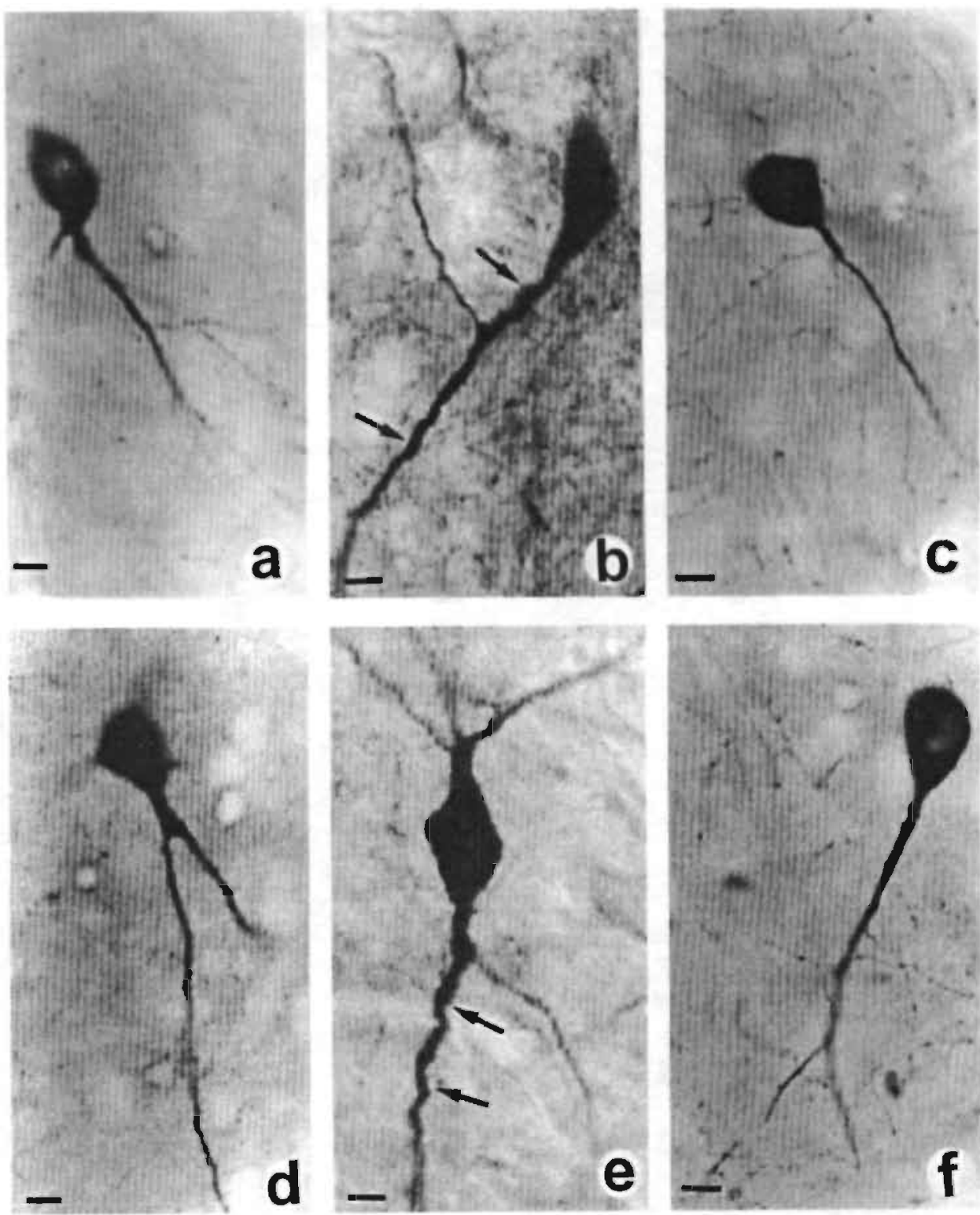

Fig 21 : Photomicrographs of striatal (a-c) and cortical (d-f) MADPH-d (+) neurons of 6 momths: old rats in sections from (a and d) control, (b and e) severe PA and (c and $f$ ) 100 min of PA at $15^{\circ} \mathrm{C}$. Note cytomegalic soma and tortuous dendritic branches in a severa PA striatal (b) and cortical (e) neurons (arrows) compared with control and PA/ $15^{\circ} \mathrm{C}$ cells. All cells at same mag. nification. Scale bar: $10 \mu \mathrm{m}$. 


\section{cortex}
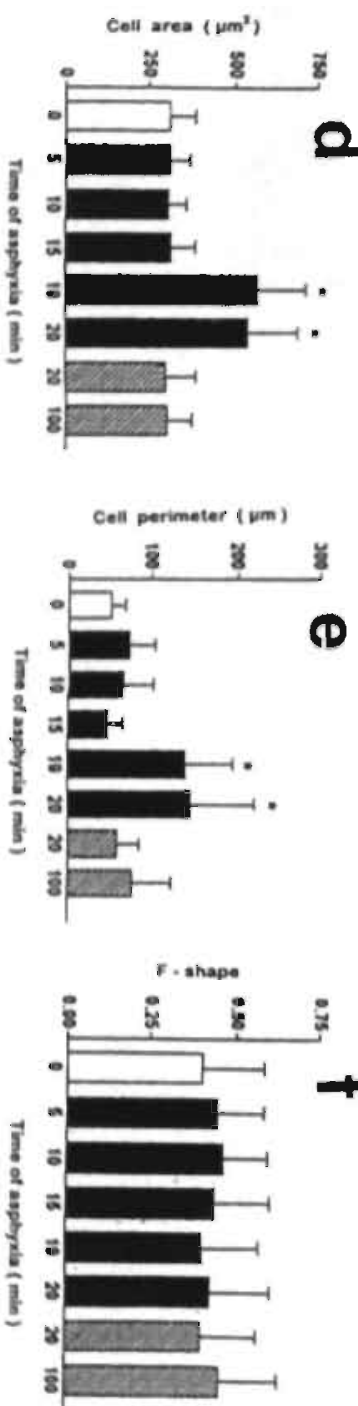

\section{striatum}

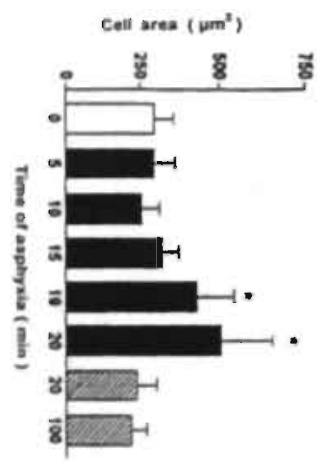

ט
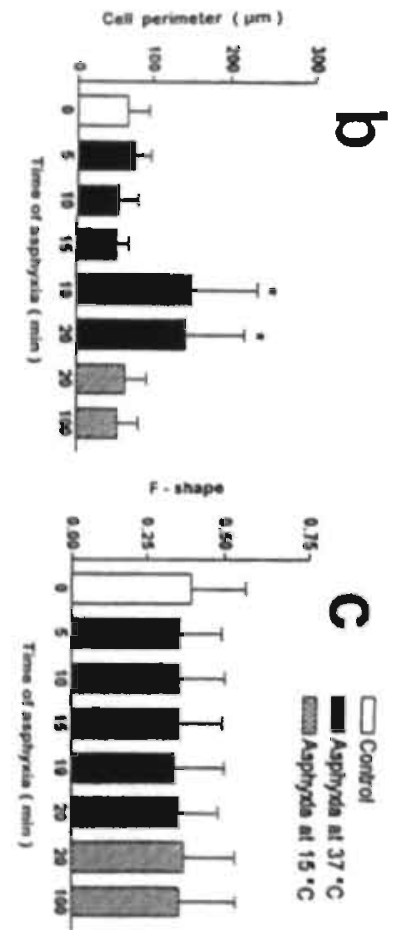

Fig 22 : Measurement of striatal NADPH-d (+) cell area (a), cell perimeter (b) and' F-shape (c), in 6 months old' rats subjected to different PA periods of time at $37^{\circ} \mathrm{C}$ or $15^{\circ} \mathrm{C}$. Each value presents mean $\pm S C$, (vertical lines) of determinations made from $n=100$ cells of each group. Asterisks indicates that differences in NADPH-d (+) cells in these two groups were highly significant $(\boldsymbol{\mu}<0.001)$ compared with the remainder. Statistical analysis was performed by ANOHA test. There were no significant differences between subsevere and severe PA. No significant diffrences in F-shape (c) were found for any group inter se. 

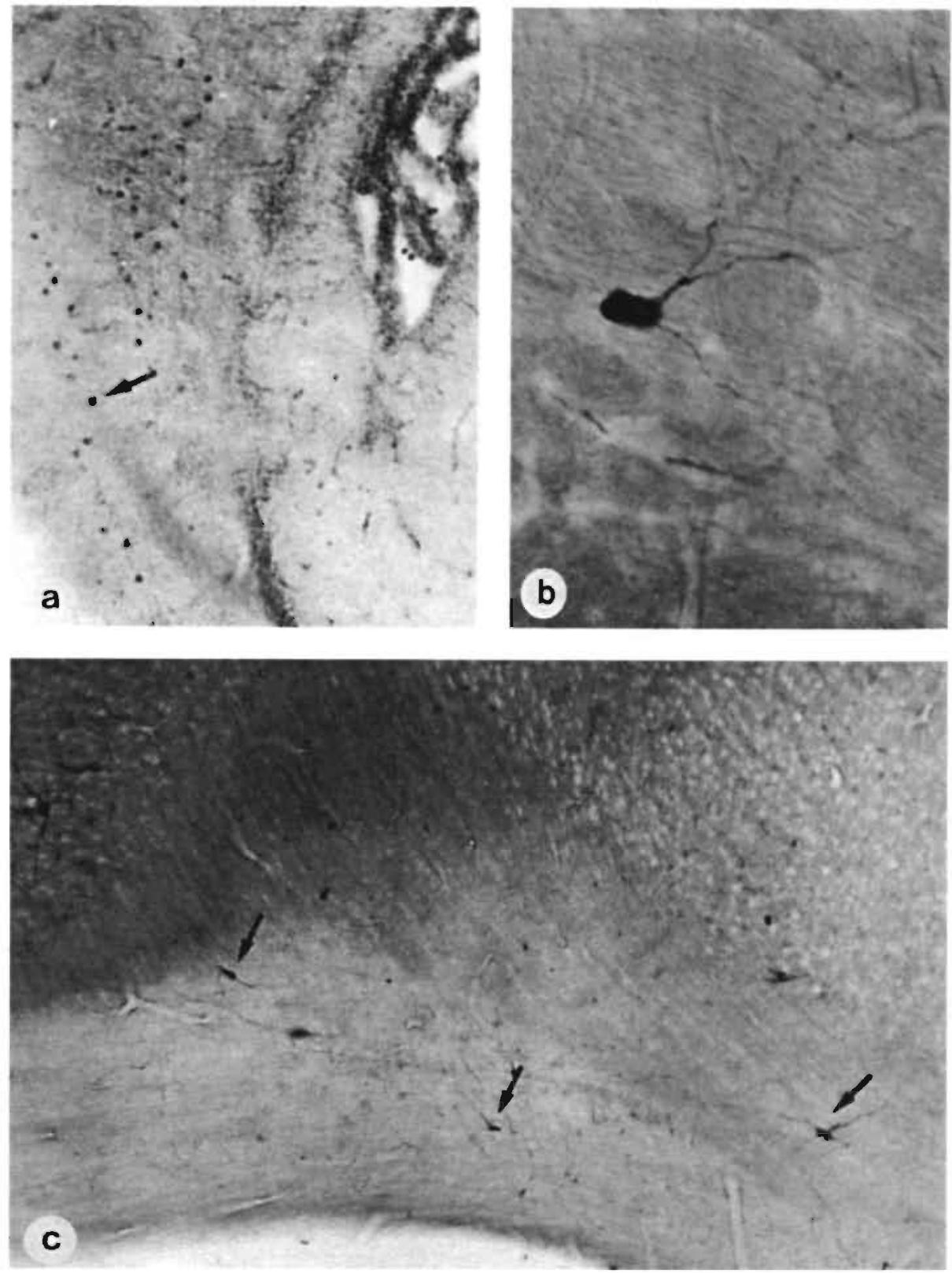

Fig 23 : Photomicrographs of the corpus callosum using WADPH-d staining in rats subjected to PA. : fail of the corpus callosum in nowborn rat after sovere PA $(100 x), b(500 x)$ and $c$ (200x) shows the corrpus callosum of 6 months old rats subjected to PA (100 min) and treated with bypothermis $\left(15^{\circ} \mathrm{C}\right)$ during insult. 
CHAPTER 5 


\section{GENERAL DISCUSSION}

5.1 Utility of the model: The non-Invasive experimental model used and presented In thls thesls was developed In order to obtaln global asphyxia without a need for invasive procedures such as carotid ligature. Precisely at dellvery, it produces global asphyxla with the alm to mimlc pathologlcal sltuations occurring during human labour. This model presents the advantage of being relatively economlc and easlly reproduclble. It allows to observe and evaluate behaviour and physical characteristics in newborn pups. Therefore, different parameters simllar to those of the Apgar's test can be measured after birth. The present model also allows to study the long-term effects of PA.

In the study of severe neonatal Ischemla, several models have been used. However, the malority are invasive (e.g. carrled out with carotld ligature) and performed on one-week-old or older pups (Hossmann, 1991; Raju 1992). However, It must be polnted out that the use of one-week-old or older pups is preferred by many scientists (Vannucci, 1992) because there is evidence showing that, at one week of age, the maturation of the cerebral cortex of a rat best matches that of the full-term newborn human Infant (Romijin, 1991). Nevertheless, whether this perlod is also optimal to study other brain regions is not clear.

5.2 Behavioural evaluation: As shown In Tables I-III and Figs. 5-6, the percentage of survival of pups is drastically decreased in the period $>19 \mathrm{mln}$ at $37^{\circ} \mathrm{C},>30 \mathrm{mln}$ at $30^{\circ} \mathrm{C}$ and $>100 \mathrm{~min}$ at $15^{\circ} \mathrm{C}$. Pups surviving prolonged asphyctic perlods showed several signs of physiological impairment; they were, however, accepted by surrogate mothers. An Interesting observation was that animals suffering severe PA showed hypotony at the beginning, becoming hypertonic a few minutes later and presented an evident rigidity, mainly in their hind legs (Loldl, 1994). This is comparable to what is seen In human infants suffering PA with an Apgar score $<3$ after 10 minutes who change from hypotony to hypertony, something taken as a bad prognosis (Percy, 1986). Brann \& Dykes (1977) suggest that the development of muscle tone implies a good prognosis for survival and posterior neurologic function. Hypotonic infants who rapidly recover a normal muscle tone within the first 2 hours survive without sequelae. Infants with a sustained hypotony lasting 4-5 days will elther dle or present sequelae; and bables born hypotonic, but who within thelr first 24 hours rapidly change to hypertony have both a higher chance of survival but also of presenting neurologic sequelae. When constant convulsions appear, or the EEG shows persistent abnormalites, the probabllity of sequelae increases. These short-term alteratlons in tone could Indicate an early disfunction In the basal ganglia. 
5.3 Why are neonates more resistant to asphyxia? High resistance to lack of oxygen in the newborn is due to specific metabollc characteristics as well as differences in the structural organization of the cerebral and miocardic neonatal tissue.

During hypoxia, besides the cerebral defensive mechanisms, a neonate's brain consumes less oxygen than that of an adult, acidosis is milder, body ternperature decreases and the still present fetal haemoglobin optimally carries oxygen. Moreover, the neonatal myocardium and cardlovascular system are more resistant to hypoxia than those in adults (Volpe, 1987; Drahota, 1991).

\subsection{Hypothermia and survival protection to asphyxia: $A$ tempe-} rature decrease from $37^{\circ} \mathrm{C}$ to $30^{\circ} \mathrm{C}$ or $15^{\circ} \mathrm{C}$ during asphyxia results in a signiffcant increase in animal survival.

The protective effect of hypothermla has been used worldwide amongst primltive peoples (Sir J. Floyer, 1697; Floyer \& Baynard, 1706) and its effect on survival following asphyxia was first studled by J.A. Miller et al. in the fifties and sixties. It was suggested that man may have discovered the advantages of low temperature for asphyctic neonates in the glacial period. Then, infants who seemed to be dead were taken outside the caves, left in the cold, and began breathing (see Miller, 1971). Miller et al. have demonstrated that deep hypothermia is an effective treaument in Induced asphyxla in a number of species of newborn anlmals. Based on thelr experimental evldence, the use of hypothermla In the treatment for severe PA was recommended (Miller, 1964, Westin, 1959, 1963). Some clinical applications were carried out combining hypothermla with positive pressure ventilation in order to resuscitate asphyctic neonates that, according to clinical experience, were otherwise absolutely certaln not to recover. Thus, if the infants died, their consclence would be clear (Dunn \& Miller, 1969; Westin, 1971, Cordey, 1964). In one of these studies (Dunn \& Miller, 1969), 28 infants were selected for cooling when after 5 minutes Apgar scores had neither changed nor increased. The Apgar of some of these Infants was 0 . It is important to remember that an Apgar score between 0 and 2 at 5 minutes results in mortality in almost $50 \%$ of the cases (Drage, 1964). Hypothermla was induced by immersing the infants - with the exception of eyes, nose, and mouth Into a watertub filled with cold water and Ice cubes, maintaining temperature between 8 and $14^{\circ} \mathrm{C}$. Infants were kept in water until spontaneous, unassisted respiration was established. After Immerslon, positive pressure ventilation was performed in order to stimulate stretch receptors of the lungs. Then, they were removed from the tub, dried and placed In the nursery wlthout active rewarming. During this process, there was a mean Increase in Apgar score of 6.4 unlts in 7.6 minutes, and all infants, but three, began to breathe. Three infants died: the death of two of them was explained as due to prematurtty presenting respiratory distress and the third infant presented congenital cardlac abnormalities Incompatible with llfe. No death was attributed to cold exposure. Surviving infants were 
followed-up for two years, and their pedlatric examination showed normal development (Dunn \&x Miller, 1969).

The term hypothermia is used rather loosely by clinicians. It refers to a central body temperature of less than $36^{\circ} \mathrm{C}$. In young infants, this is best determined by inserting a low-reading thermometer into the rectum to a depth of not less than $\mathbf{2 . 5}$ centimeters, the readlng being taken after a minlmum perlod of two mlnutes (Mann, 1963). The hlgh resistance to applying cold treatment, and the general bellef that under no circumstance may an Infant's temperature be allowed to fall, comes from the knowledge that extended exposure of premature infants to cold (Sllverman, 1958, Buetow \& Klein, 1964, Day, 1964) and accidental long-term exposure to cold (Mann \&. Elliot, 1957) increase mortallty In term infants. Although It is accepted that long-time exposure to cold is dangerous, there is no evidence that a short-time decrease In body temperature is dangerous nelther Immedlately after birth nor during asphyxia (Dunn \& Miller, 1969).

Lately, the protective effect of hypothermia has also been widely studled in experimental translent forebrain ischemia (Globus, 1988; Coimbra \& Wleloch, 1992, Glnsberg, 1992), where low intraischemic brain temperature can protect braln neurons. This effect is probably due to a reduction in the brain's energy demands and consequently, a decrease in the rate of ATP depletion (Young, 1983).

5.5 Glutamate antagonists and perinatal asphyxia: Competitive and non-competitive NMDA and AMPA antagonists have been suggested as useful neuroprotectlve agents In both focal and global ischemia (Sheardown, 1990; Scatton, 1991, Barks \& Sllversteln, 1992). Therefore, establishing a comparlson between the protectlve effect of hypothermia wlth that of glutamate antagonists is Interesting. A serles of experlments ylelded the following information:1) if the dizocllpine dose was above $0.5 \mathrm{mg} / \mathrm{kg}$ s.c., It was lethal to pups delivered by hysterectomy, 2) If the dizocilplne dose was $0.3 \mathrm{mg} / \mathrm{kg}$ s.c., mortality was not Increased - but pups were still not accepted by surrogate mothers, 3 ) If the dizocllpine dose was $0.2 \mathrm{mg} / \mathrm{kg}$ s.c., pups were accepted by surrogate mothers. It was also establlshed that dlzocllpine $(0.2 \mathrm{mg} / \mathrm{kg}$ s.c.) could slightly increase survival (from $3 \%$ to $19 \%$ ) in an induced $21-22$ minute asphyctic period at $37^{\circ} \mathrm{C}$ (Herrera-Marschitz, 1993). However, when asphyctic periods were longer, no protectlve effect was observed. The observation that MK 801 induces a prolonged hypothermla in treated animais has led to controversy dizocilpine's protective effect (Bunchan, 1990, 1991).

Because Judge et al. (1991) reported a protective effect of the AMPA antagonlst NBQX, this drug was also tested to increase survival rate following asphyxla. NBQX, In a $30 \mathrm{mg} / \mathrm{kg}$ s.c. dose, increased survival after asphyctic periods of 21-22 minutes (from $3 \%$ to $21 \%$ ) and 22.23 (from 0 to $18 \%$ ) (Table IV; Fig 13). No signs of protection were observed in pups subjected to asphyctic periods longer than $\mathbf{2 3}$ minutes. This data suggest a preventive effect on glutarnate antagonists. However, its effect is less significant than that of hypothermia. 
5.6 Subcutaneous microdialysis. Indicator of long-term damage as a prognosis tool? As shown in Figs. 7-11, In slight P,A, there is a slight increase in the subcutaneous levels of Glu, Asp and Lac in comparison with control group, and Pyr is clearly higher and Asc, lower. In moderate asphyxla, s.c levels of Glu and Asp are peaking, Lac is still increasing, Pyr is decreasing towards normal levels and Asc remains under the control group's levels. In severe PA, Glu and Asp levels are decreasing, Lac is peaking, and no difference in Pyr and Asc was observed when compared with moderate PA. A subcutaneous measurement of these substances in infants who suffered PA, or those suspected to have suffered it, might be a useful tool in prognosis of possible damage. It was interesting to observe that when PA was induced at about $30^{\circ} \mathrm{C}$, s.c. levels of excitatory aminoacids and metabollc products were similar to those observed at $37^{\circ} \mathrm{C}$ whereas when induced at about $15^{\circ} \mathrm{C}$, levels were almost normal compared with those of control group, with the exception of Lac, which always increases while asphyxia is sustained.

Pyr is the main product of głycolysis which, under aerobic conditions, enters the mitochondria where it is completely oxidized to $\mathrm{CO}_{2}$ and $\mathrm{H}_{2} \mathrm{O}$. Consequently, extracellular Pyi levels should increase whenever there is an Increase in energy demand. If the supply of oxygen is insufficlent, Pyr is converted into Lac (Hañsen, 1985; Siesjö, 1978). Accumulation of Lac is an Indication of a shlft from aerobic to anaerobic metabollsm. Therefore, an Increase In Pyr levels after a short period of PA might Indicate an increase in glycolysls, probably via an increase in phosphofructokinase and pyruvate klnase activity ( Siesjō, 1978; Hansen, 1985; Volpe, 1987; Luz, 1992). After asphyctic perlods longer than 10 minutes, glycolysis decreases, probably due to the production of $\mathrm{H}^{+}$ions derived from NADA and inhibition of phosphofructokinase (Vanuccl, 1991; Luz, 1992), resulting In a decrease in Pyr levels, while Lac accumulation is still sustained.

The orlgin of subcutaneous Glu and Asp is probably both metabollc and neuronal. A microdialysis probe was implanted into a region showing strong Glu- and Asp-IR, partly in fiber-like structures, which may represent sensory nerves (Nordlin, 1993). Both Glu and Asp levels Increased significantly following PA, reaching the maximum at 10-11 minutes and 15-16 minutes asphyctic periods. This delayed increase in Glu probably reflects a shift in the aspartate-aminotransferase reaction, concomitant with the shift from aerobic to anaerobic metabolism (Hansen, 1985; Siesjo, 1978), as Indicated by the Pyr to Lac conversion. However, the increase in Glu and Asp levels may also be due to inhibition of the ATP-dependent re-uptake pump for the aminoaclds (Naito, 1983, 1985; Robinson, 1993). Increases in aminoacid levels have been observed in several experimental models of PA (Johnston, 1983), and are considered to be the cause of cytotoxic cascades with increased excitability, increased energy demands and intracellular calcium accumulation (Chol, 1990). However, it was found that subcutaneous Glu and Asp progressively decreased to control levels in longer asphyctic periods. This decrease In aminoacids probably reflects an inhibition of Glu synthesis in extreme anaerobic conditions (Luz, 1992). 
Independently from the temperature used, the group exposed to PA had a lower level of Asc when compared with the control group. Furthermore, a decrease in ascorbate was found in the amniotlc fluld of pregnant women who were smokers and in pregnancles complicated with premature rupture of membranes. Thls observation led to suggest that the use of Asc as an antioxidant might have a protective effect (Barret, 1991)

\subsection{Do long-term dopaminergic changes represent a sign of} accelerated ageing? The effect of PA on DA levels appears to depend on the length of an asphyctlc period: In moderate PA an Increase in DA was observed whereas in severe PA a decrease in DA was observed. The Increase In basal DA levels In moderate asphyxla (19-20 mln) might agree with a histochemical study (Bjelke, 1991) showing that given the same condltions, asphyxla produced an increase in number of tyrosine hydroxylase-Immunoreactive (TH-IR) nerve cell bodles: a sign of prollferation of dopaminergic neurons. It has been suggested that the cause for this Increase In nigral DA cell bodles is a deficit in GABAergic surlato-nlgral feedback, which would set the nigrostrlatal DA neurons in hyperactl-

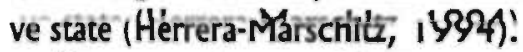

Some reports suggest that an excesslve release of striatal DA might play a neurotoxic effect, and this cerebral area is particularly sensitive to ischemic Injury (Smith, 1984). In agreement with this hypothesis, a lesion in the nigrostriatal dopaminergic neurons would protect from ischemic damage in the strlatum (Globus, 1987), and DI dopaminergic antagonlst Sch 23390 would Increase the protective effect of MK-801 (Globus, 1989). The toxlc effect Induced by DA mlght be due to oxidative products that lead to the production of hydrogen peroxyde and hydroxyl radlcals. Furthermore, the strong vasoconstrictor effect of DA mlght contribute to damage. It is Interesting to add that DA release seems to be temperature-dependant, and can be decreased with hypothermla (Globus, 1988).

Rats survlving asphyctlc perlods longer than 20 minutes (severe PA) showed chronic deficits in the release of several putative neurotransmitters monitored with microdialysis in the basal ganglla. In compartson with the control group (vaginally-or caesarean dellvered rats), the main change observed in six-monthold rats after severe PA was a marked decrease in DA release monitored under basal and D-amphetamine stimulated conditions (Loidl, 1994). In agreement with the present observation of a reduced DA release in the neostriatum and a reduced GABA release in the subscantia nigra, other experiments showed that following severe PA, rats presented a decrease in the rate of spontaneous locomotor activity (Andersson, 1992). Whether the chronic effect on DA release is primarlly due to PA or secondary to other neurotransmitter systems is not yet known. However, in a recent study (Andersson, 1995), changes In the number of TH immunoreactive nerve cell bodles and also In the basic Fibroblast Growth Factor (bFGF) gene expression were observed in the substantia nigra of asphyctic rats, four weeks after birth. 
In the case of severe PA, the decrease in DA levels might be correlated to some mechanisms of retrograde degeneration of the nigrostriatal pathway. AJthough it is accepted that dopaminergic transmission decreases with age, and that this decrease is enhanced in several neurodegenerative disorders such as Parkinson's and Alzheimer's diseases (Glaquinto, 1988), it is not known whether PA is related to blochemical features observed in these accelerated ageing processes. It is our hypothesis that e.g. decreases in DA levels observed in adult stages might be related to perinatal asphyctic lesions (Loidl, 1994).

\subsection{Asphyxia and reactive astrocytosis. GFAP immunostaining:} For many years, the idea that gliosis was only a passive scar and therefore interfered with repairing the damaged braln was accepted. In recent years, this concept has been completely reviewed as a consequence of having establlshed that astrocyte cells are capable of releasing certain factors that induce axonal growth and satmulates neuronal reparation. CNS responds to all types of noxae with astrogllal hyperplasia and hyperthrophla. Its extent can be determined by specific immunomarkers in these cells. Numerous reports have demonstrated the high specificity of glial fibrillary acidic proteins (GFAP) -which have a structural role since they are the main intermedlate fllaments that form the cytoskeletal frame in these cells.

A perinatal hypoxic-ischemic lesion produces characteristlc changes in the CNS, typically seen In children affected by severe PA and who, subsequently, present intellectual difficuldes, epilepsy or motor alterations. One of these morphological alterations is the "marmoratus staus", which is generally restricted to the basal ganglia and thalamus. This marmoratus staus, so-called due to the typlcal marbled aspect of these cerebral structures, was atuributed to a gllosis and hypermyelinization (Percy, 1986).

The astroglial reaction observed with GFAP Immunostalning In animals subjected to severe PA could on the one hand be correlated to the status marmoratus observed in humans and on the other explain the low levels in striatal extracellular Glu and Asp registered by in vivo microdialysis (Loidl, 1994) since their capacity as "buffers" to reuptake excesslve excltatory aminoaclds from the medlum -something potentially toxic- is known (Drejer, 1985).

It is widely accepted that in ischemia there is an important decrease in protein synthesis, GFAP together with heat shock proteins (HSP) (Capanl, 1996) and a neuronal c-Fos (Dell'Anna, 1995) and c-Jun increase. Although the role and signlficance of these proteins is stlll being discussed, the possibillty of their playing an important role in resisting ischemia, cellular activation, differentiation and regeneration is present. 
5.9 Perinatal asphyxia and hypertrophy of NF. A sign of neurodegenerative and accelerated ageing?

An Increase In $230 \mathrm{kD}$ neurofilaments (NF) Immunoreactivity in severe asphyctic anlmals was clearly observed in the neostriatum, and this agrees with other authors' findlings that poswulate thls NF as neurodegenerative markers (Nlxon, 1991; Klossen, 1994). Immunostaining In NF is well evident in the "striatal patches", the place where axons - mostly originated in cortlcal neurons - cross this nuclel. Axons are more stalned than somas because they have a hlgher amount of NF and because antlbodies have a greater affinity with the phosphorylated epltopes, mainly present in axons (Drake, 1984). A great amount of neurodegeneratlve pathologles are characterized by a morphological reorganization of thelr cytoskeleton. Examples of thls are: Alzheimer's disease, idiopathlc and postencephalic Parkinson's disease (with the Lewls's Incluslon of filamentous nature), amyotrophic lateral sclerosis, Down's syndrome, Pick's disease (all with Intra neuronal Inclusions) and In Infantlle spasms, where the presence of argyrophillic neurofibrillary-Ilke tangles and cytoplasmic vacuoles is associated with cytomegallc neurons (Vinters, 1992). Tangles of neurofilaments, present both in Alzhelmer's disease and normal ageing, reinforce the theory of a possible accelerated ageing process stimulated by severe PA. The massive and rapid accumulation of axonal aberrant NF might be associated to an Increase in their production with hyperphosphorylation (Nixon, 1991) or to an Increase in thelr degradation, performed by a klnd of proteases called calpains (Roberts-Lewis, 1994).

Axonic transport assoclated with this type of NF could atso be involved in these pathologles, but the mechanlsms responslble for producing NF accumulatlon and the slgniflcance of these changes remaln unclear (Gajdusek, 1985).

5. 10 Cytomegalic NOS-containing neurons associated with PA: A sign of neuroprotection or neurotoxicity?

a. Acute changes in NOS after PA (newborn rats): Immediately after Inducing asphyxla, the expresslon of NADPH-d changes in the lateral zone of the strlatum and In some cortical neurons was observed. Striatal NADPH$\mathrm{d}(+)$ neurons Increased the thlckness of their processes, but always kept a lateral locallzation in the striatum, suggesting that PA might induce some kind of stlmulation In NOS expression. This, phenomenon produced the appearance of NOS in places where noimally, at this stage, it is not present.

The entire cell, including the soma and processes, was intensely stained. An Increase In NADPH-d( +) staining of the blood vessels in striaturn and cortex was also observed In severe asphyctic animals, Indlcating that at this early post-ischemic period, vasodllation takes place in an effort to enhance oxygen supply to the tissues. 
Negative staining of NADPH-d in cortical neurons in the newborn control group agreed with a recent report showing that in rats this entyme is present up until 19 days prior to birth, and then begins to decrease up until day $O$ postnatal (Bredt, 1994). In pups with induced PA, some cortical granular type neurons expressed NADPH-d $(+)$ staining.

It was striking to observe that under hypothermla at $15^{\circ} \mathrm{C}$ for 20 and 100 minutes, although PA survival increased around $\mathbf{5}$ times, it prevented changes in neurons containing NADPH-d. This lower metabolism induced by hypothermia might lead cells to save energy consumption, something that could be important for survival by Inhibiting cellular neurotoxicants triggered by ischemla. Corpus callosum presented NADPH-d $(+)$ rounded cells in all newborm group. The nature of these cells is controversial, and further experiments should be carried out so as to determine whether they are gllal type cells, macrophages (Peng, 1994) or neurons in a migration process. NADPH-d+cells with the typlcal neuronal morphology In corpus callosum of adult rats were observed only in the hypothermic treated group. A recent report attributed these NADPH + cells in corpus callosum to Martinotti's neurons, present in the deeper layer of the cortex (Luth, 1994).

b. Chronic changes in NOS after PA (6 month-old rats): In agreement with authors who described NADPH-d $(+)$ striatal and cortical cells as interneurons containing somatostatine and neuropeptide $Y$, these neurons in adult rats were medlum-sized and non-splny in type (Ferrante, 1985; Vincent \&x Hope, 1992). Given their lack of NMDA receptors (Vincent \& Kimura, 1992) and their high concentration of manganese superoxlde dismutase, (Inagakl, 1991) these cells were seen as resistant to excltatory aminoacld toxlcity and free radical toxicity respectively. However, wider impllcations of NO as a neurotoxlc or neuroprotective modulator are still subject to controversy (Schuman \& Madison, 1994). Certain neurological disorders have been reported to induce changes In NADPH-d stained neurons. Some sudies on patlents with Huntington's disease have disclosed an increase in the striatal NADPH-d + ( ) cell measurements assoclated with cell and fiber sparing, which can be attributed to the loss of striatal splny neurons (Vincent 8 Hope, 1992) Recently, a report on human Parkinson's and Alzheimer's diseases has documented a relative NADPH-d $(+)$ cell sparing In striatal neurons with shrunken and foreshortened dendritic processes (Mufson \& Brandabur, 1994). In our findings, NADPH-d technlque dlsclosed positive cells of the same type, homogeneously distributed in strlatum and cortex of asphyctic and control animals, shown by F-shape analysis. However, strlatal and cortical NADPH-d $(+)$ neurons of rats sublected to moderate or severe PA were highly cytomegallc compared with control and hypothermia-treated animals, suggesting that the pathological mechanism related to NO involved in PA is different from that in Alzheimer's, Parkinson's, and Huntington's diseases.

In agreement with Mischel et al. (Mischel, 1995) who documented cortical neuronal cytomegaly in pediatric epilepsy (data from 77 patients who underwent surgical cortical resections for intractable seizures), our study found similar altera- 
tlons In rat striatal and cortlcal NADPH-d(+) neurons in the striatum and cerebral cortex of 6 month-old rats exposed to moderate or severe PA.

Since NO Induces DA release, whlch can be blocked by administering the NO synthase Inhlbitor, L-Me-Arg (Zhu \& Luo, 1992), the highest basal level of suriatal DA chronlcally malntalned following subsevere PA (Herrera-Marschlz, 1994) appears to correlate closely with the number of NOS-containing cytomegalic striatal neurons.

Amongst other functions, NO plays a relevant role In regulating blood flow by Inducing relaxation of the vascular smooth muscle (Palmer, 1987) providing, perhaps, protection agalnst ischemia by Increasing oxygen supply. Since NO stimulates DA release, reportedly toxlc in strlatum following ischemia, its potent vasoconstrictor effect may well worsen cell damage. However, since DA release is Inhlblted by hypothermla (Globus, 1987, 1988), Its protective mechanism might be the Inhlbitlon of an excessive release of strlatal DA indirectly stimulated by NO. The functional consequences resulting from striatal and NO-containing cytomegallc neurons after subsevere or severe PA are yet to be determined.

Desplte the therapeutlc application of hypothermla in controlling severity of Ischemic cerebral damage described in rats (Busto, 1987) and gerblls (Busto, 1989), only a few studies on PA were performed In the fifties and sixties, when cold therapy plus positive pressure ventilation was introduced in order to resuscitate severely asphyctlc human neonates previously considered incapable of recovery (Westin, 1971). Mechanisms underlying the protective effect of hypother$\mathrm{mla}$ are not clear. A decrease In metabollc demands occurs when body temperature is lowered. Subsequent toxic effects are weakened and survival to prolonged exposure to asphyxla without permanent brain leslons is ensured. A prolonged duratlon of hypothermla might also help in the recovery of normal cellular $\mathrm{Ca}^{++}$ homeostasis (Colboume, 1994).

Neuronal heterotopla, Islands of dlsorganized neurons within the subcortical white matter, was found In some cases of pedlatric epllepsia (Mischel, 1995) and It has been suggested that Injury to radlal flbers (e.g. in a vascular Injury) might stop the migration of neuroblasts, later leading to a single heterotopic white matter neurons (Sarnat, 1992). Interstltial neurons in white matter are the oldest cells of the cortex/white matter and most are derived from subplate neurons; as an hypothesized result of apoptosls these neurons decrease and disappear during development and maturation. Therefore, heterotopic neurons in white matter may be due to a failure of programmed cell death (Chun \& Schaz, 1989). In our study, heterotoplc neurons In corpus callosum were only observed in 6 month old rats exposed to hypothermia. Either a halt to the neuroblast migration process or a fallure of the apoptotic mechanism - or both - might occur with hypothermla.

Further experimental studies on cold therapy for PA treatment are necessary in order to clarify the functional Implication of this observation. 
CHAPTER 6 


\section{CONCLUSIONS}

1) A non-Invasive experimental model that allows to study short- and longterm consequences of pertinatal asphyxia is presented.

2) Survlval rate after PA depends on both duration of asphyxia and temperature at which it is performed. At $37^{\circ} \mathrm{C}$ body temperature, an asphyctic period longer than 22 minutes is asscciated with $100 \%$ mortality, $100 \%$ survival is only observed up to a 16 minute period of $P A$. At $30^{\circ}$, o $100 \%$ survival is observed up to a 30 minute period of PA. At $15^{\circ} \mathrm{C}, 100 \%$ survival is still observed up to a 100 minute period of PA.

3) PA mortallty at $37^{\circ} \mathrm{C}$ can be decreased by the shifting of temperature from $37^{\circ} \mathrm{C}$ to $15^{\circ} \mathrm{C}$ during the perlod when asphyxla is induced. Prevention of mortality is obtained by the shitting of temperature from $37^{\circ} \mathrm{C}$ to $15^{\circ} \mathrm{C}$ during the period up to 15 minutes after starting induction of PA. After this period of time, a shift in temperature does not prevent mortality.

4) A sllght reduction In mortallty rate is obtained when treating mothers with glutamate antagonists one hour before dellvery. NMDA and AMPA antagonists $1+/ M K$ 801 and NBQX produced only a slight increase in survival at maximal doses; their effect was improved when both were simultaneously administered.

5) Several metabolic products and excltatory aminoacids were monitored using in vivo mlcrodlalysls in subcutaneous tissue for $\mathbf{4 0 - 8 0}$ minutes after delivery. The most important changes in $P A$ at $37^{\circ} \mathrm{C}$ were seen in Glu and Asp levels with a maximal incre. ase following a 10.11 minute asphyctic period. PA at $15^{\circ} \mathrm{C}$ proved to prevent changes in Glu and Asp.

6) Rats surviving asphyctic periods longer than 19 minutes at $37^{\circ} \mathrm{C}$ showed chronlc alterations in the release of neurotransmitters monltored with in vivo microdlalysis in the basal ganglia. The main change observed after 6 months in rats subjected to subsevere PA (19.20 min) was an increase in DA levels whereas those subjected to severe PA (> $20 \mathrm{~min}$ ) presented a decrease in $D A$ levels compared with controls. However, both groups presen. ted a decrease in DA release after stimulation with D-amphetamine. 
7) Present findings show that NADPH-d reactivity is enhanced in striatal and cortical neurons containing-NOS secondary to subsevere or severe PA.

An increase in neuronal NADPH-d staining in pups, and chronic changes in adult animals revealed by cytomegalic neurons containing-NOS was observed after subsevere and severe PA. It was also demonstrated that these changes may be prevented with hypothermic treatment.

8) Immunostaining to glial fibrillary acidic protein (GFAP) revealed that subsevere and severe PA Induces chronic changes in the expression of these intermediate filaments in strlatum, substantia nigra and cortex. PA induced under hypother. mic condition $\left(15^{\circ} \mathrm{C}\right)$ prevents reactive astrocytosis.

9) Immunostalning to $230 \mathrm{kD}$ neurofilaments (NF) revealed that subsevere and severe PA induces chronic changes in the expression of these intermediate filaments in the striatum. Changes observed in this type of NF indicate that PA induces neuro. nal filamentous accumulation compatible with several diseases.

10) Therefore, this experimental model appears to be useful to study shortand long-term consequences of hypoxic-Ischemic lesions in rats, Induced under conditions simllar to those found In labour in clinlcal sluations. Further studies on cold therapy for the treatment of severe PA should be re examined and carried out without delay.

11) Asphyxla during birth might be a factor contrlbutng to the development of neurodegenerative diseases such as accelerated ageing processes, Parkinson's and Alzheimer's diseases.

12) An Irreversible cerebral lesion, resulting from $P A$, is a tragedy for a chlld and its family. Also, it increases medical, soclal and economic demands on society. Therefore, one of the objectives of obstetric and neonatal care that also is a challenge to science is to decrease the number of children damaged by PA. 
CHAPTER 7 


\subsection{SUMMARY}

Acute perinatal asphyxla (PA) is still the major cause of death and neurological Injury In newborm Infants at term. A non-invasive experimental model that allows to study short- and long-term consequences of PA is described.

The percentage of survival after PA depends on: a) duration of PA and b) temperature at whlch asphyxia is induced. At a body temperaure of $37^{\circ} \mathrm{C}, \mathrm{PA}$ lasting over 22 minutes results in 100\% mortality whereas If PA ends before 16 minutes, there is $100 \%$ survival. At $30^{\circ} \mathrm{C}$, there is $100 \%$ survival if the duration of PA is up to a perlod of 30 minutes. At $15^{\circ} \mathrm{C}$, PA lasting up to 100 mlinutes still results in $100 \%$ survival. At $37^{\circ} \mathrm{C}$, PA mortality can be decreased by shlfting temperature from $37^{\circ} \mathrm{C}$ to $15^{\circ} \mathrm{C}$ durlng the asphyctlc period, if this shifting is performed withln the first 15 minutes of the beginning of asphyxia. Later than this 15 minute period, shlfting temperature no longer prevents mortallty.

A sllght decrease in mortality rate can be achieved by adminlstering glutamate antagonists to the mother, one hour before dellvery. NMDA and AMPA antagonlsts (+)MK 801 and NBQX produced only a slight Increase In survival at maximal doses; their effect was Improved when both were simultaneously administered.

Several metabolic products and excitatory aminoaclds were monitored using In vlvo microdlalysis In subcutaneous tissue for 40-80 minutes following delivery. The most important changes produced by PA at $37^{\circ} \mathrm{C}$ were seen in Glu and Asp levels, whlch presented a maximal increase after a 10-11 minute asphyctic period. At $15^{\circ} \mathrm{C}$, PA produced no change in Glu and Asp.

Adult rats surviving asphyctc perlods longer than 19 minutes at $37^{\circ} \mathrm{C}$ showed chronic alterations in the release of neurotransmitters, thls was monitored with in vivo mlerodialysis In the basal ganglla. After 6 months, the maln change observed In rats sublected to subsevere PA (19-20 minutes) was an Increase in DA levels; those sublected to severe PA ( $220 \mathrm{~min}$ ) presented a decrease in DA levels compared with controls. However, both groups presented a decreased DA release following sumulation with D-amphetamine.

Morphological studies demonstrated that NADPH-d reactivity is enhanced in strlatal and cortical neurons containing-NO secondary to subsevere or severe PA. After subsevere and severe PA, an increase in neuronal NADPH-d staining in pups, and chronic changes in the adult animals, revealed by cytomegalic neurons contalning-NO, was observed. Another observation was that these changes may be prevented by cold treatment. Immunostalning to glial fibrillary acldlc protein (GFAP) revealed that subsevere and severe PA induce chronlc changes in the expression of these Intermediate filaments In striatum, substantia nigra and cortex. PA Induced under hypothermic conditions $\left(15^{\circ} \mathrm{C}\right)$ prevents reactive astrocytosis. Immunostalning to $230 \mathrm{Kd}$ neurofilaments (NF) revealed that subsevere and severe PA Induce chronic changes in the expression of these Intermediate filaments 
in the striatum. Changes observed in this type of NF indicate that PA induces neuronal flamentous accumulation compatible with several diseases.

Therefore, this experimental model appears to be useful to study short- and long-term consequences of hypoxic-Ischemic lesions in rats, induced under condtions similar to those found in labour in clinical siwations.

Further studies on cold therapy for the treatment of severe PA should be reexamined and carried out without delay. Asphyxia during blrth may be a factor contributing to the development of neurodegenerative diseases, such as accelerated ageing processes, Parkinson's and Alzheimer's diseases. An Irreversible cerebral lesion, resulding from PA, is a tragedy for a child and lis familly. Also, it increases medical, social and economlc demands on soclety. Therefore, one of the objectives of obstetric and neonatal care - that also is a challenge to science is to decrease the number of children damaged by PA. 


\subsection{SAMENVATTING}

Acute perlnatale asfyxie (PA) is nog steeds de belangrijkste corzaak van sterfte en neurologlsche beschadiging bij a terme pasgeborenen. Een non-Invasief expertmenteel model dat het mogelijk maakt de vroege en late gevolgen van perinatale asfyxie te bestuderen, wordt beschreven.

Het overlevingspercentage na PA hangt af van de duur, zowel als van de temperatuur waarbi] de asfyxie werd geînduceerd. Bi] een lichaamstemperatuur van $37^{\circ} \mathrm{C}$, gaat een asfyctische periode van langer dan 22 minuten gepaard met $100 \%$ mortalltelt, terwijl 100\% overleving optreedt bl] een asfyctische perlode korter dan 16 minuten. Bl] een llchaamstemperatuur van $30^{\circ} \mathrm{C}$ echter, wordt $100 \%$ overleving gezlen tot 30 minuten PA, terwill bl] een temperatuur van $15^{\circ} \mathrm{C}, 100 \%$ overleving wordt gezien bij 100 minuten PA. De mortalitelt ten gevolge van PA kan gereduceerd worden door de temperatuur te veranderen van $37^{\circ} \mathrm{C}$ naar $15^{\circ} \mathrm{C}$ gedurende de periode dat asfyxie wordt geinduceerd, maar alleen als dat gebeurt binnen 15 minuten na de start van de asfyxle. Na deze ti]d, voorkomt verandering in temperatur geen mortalitelt.

Een klelne reductle van mortalteit wordt ook verkregen door 1 uur voor de bevalling glutamine antagonlsten aan de moeder toe te dienen. De NMDA en AMPA antagonlsten (+)MK 801 en NBQX gaven maar een klelne stijging te zlen in overleving blj een maxlmale dosis mar het effect werd verhoogd als belde tegellikertl]d werden toegedlend.

Verschlllende metabole producten en excitatolre aminozuren werden gemonltord mlddels microdlalyse in het onderhuidse weefsel gedurende 40-80 minuten na de bevalling. De meest opvallende veranderingen tlldens PA bi] $37^{\circ} \mathrm{C}$ traden op In glutamaat (Glu) en aspartaat (Asp) spiegels met een maximale toename na een 10-11 minuten durende asfyctische periode. PA bl] $15^{\circ} \mathrm{C}$ bleek veranderingen In Glu and Asp splegels te voorkomen.

Volwassen ratten die perlodes van asfyxie langer dan 19 minuten blj $37^{\circ} \mathrm{C}$ overleven, vertonen chronlsche verhoging van het villkomen van neurotransmitters gemonitord met in vivo microdialyse in de basale ganglia. De belangrijkste verandering dle gezlen wordt in ratten 6 maanden na matig-ernstige PA (19-20 minuten) was een toename van Dopamine (DA) splegels, terwill de ratten dle blootgesteld ziln aan extreme perinatale asfyxie ( $20 \mathrm{~min}$ ) een daling in DA-spiegels laten zlen, In vergelliking met de controles. Echter na stimulatle met D-amphetamine is in belde groepen een daling in DA ultscheiding te zlen.

Morphologische studles toonden aan dat NADPH-d reactiviteit verhoogd is in de NO bevattende striatdale en corricale neuronen, optredend na matige of ernstige PA. Een toename in neuronale NADPH-d kleuring bil pups, zowel als chronlsche verandertngen in volwassen dieren, aangetoond door corticale neuronen die NOS bevatten, kon gezlen worden na matige en emstige PA. Tevens werd gezien dat deze veranderingen voorkomen kunnen worden door "koude behandeling". 
Immunokleuring op gliale fibrillaire eiwitten (GFAP) toonde an dat matige en emstige PA chronische veranderingen in de expressie van deze vezels in het striatum, de substantia nigra en de cortex teweegbrengt. PA bij onderkoeling $\left(15^{\circ} \mathrm{C}\right)$ voorkomt reactieve astrocytose. Immunocytochemlsche aankleuring van $230 \mathrm{kD}$ neurofilamenten (NF) toonde aan dat matige en ernsüge PA chronische veranderingen in de hoeveelheid valn deze intermediaire fllamenten in het striatum teweegbracht. Veranderingen die gezien werden in dit type neurofilamenten geven aan dat PA een toename in het aantal neuronale vezels induceert, compatibel met verschllende ziektes.

Daarom schijnt dit experimentele model waardevol te zijn om blj ratten de korte en langdurige gevolgen van hypoxle-Ischemie, toegebracht onder identieke omstandigheden zoals dle plaatsvinden tijdens de bevalling, te bestuderen.

Verdere studles naar "koude theraple" voor de behandeling van ernstige PA zouden op korte termijn opnleuw geêvalueerd en ultgevoerd moeten worden. Asfyxie gedurende de geboorte kan een factor zijn die bijdraagt aan de ontwikkeling van neurodegeneratieve ziekten zoals versnelde ouderdomsprocessen, en de ziekte van Parkinson en Alzheimer.

Een onherstelbaar hersenletsel als gevolg van PA is een tragedle voor het kInd en zijn familie, en verhoogt de benodigde medische, sociale en economische mlddelen. Bovendlen is het verkleinen van het aantal op deze manler beschadlgde kinderen één van de doelstellingen van de obstetrische en neonatale zorg, en een ultdaging voor de wetenschap. 


\section{REFERENCES}

Andersson K., Bjelke B., Bolme P. and Ogren S-O. (1992) Asphyxia Induced lesion of the rat hippocampus (CA1, CA3) and of the nigra-strlatal dopamine system. In J. Gross (Ed). Hypoxia and

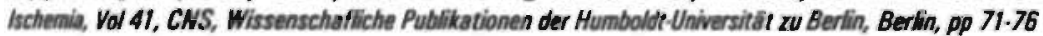

Andersson K., Blum M., Chen Y., Eneroth P., Herrera-Marschitz M., Bjelke B., Bolme P., Diaz R. Jamison L., Loldl CF., Ungethüm, Aström G. and Ogren S-O. (1995) Perinatal asphyxia increases bFGF mRNA levels and cell body number in the mesencephalon of rats. Neurofeport 6 : 375.378

Allain H., Decombe R., Salag B., Bentue-Ferrer and Guez D. (1991) Mechanistic basis for the development of anti-ischernic drugs. Cerebrovasc. Dis. 1supp/ 17: 83.92

American Psychlatric Associatlon (1987) Diagnostic and Statistical Manual of Mental Disorders (DSM III), Third Edition, Washington DC, USA

Barks J., Sllvestein F. (1992) Excitatory amino acids contribute to the pathogenesis of perinatal hypoxic-ischemic brain injury. Brain Pathology 2: 235-243

Barret C. (1981) Astrogllal reaction In the gray matter of lumbar segments after mldthoracic transection of the adult rat spinal cord. Exp Neurol 73: 365.377

Barrett B., Gunter E., Jenkins ]. And Wang M. (1991) Ascorbic acld concentration in amniotic nuld in late pregnancy. Biol Meonute 60: 333.335

Bjelke B., Andersson K., Ogren S. and Bolme P. (1991) Asphyctic lesion: proliferation of tyrosine hydroxylase-immunoreactive nerve cell bodies in the rat substantia nlgra and functional changes in dopamine neurotransmission. Brain Res 543: 1.9

Black M. and Humprey P. (1994a) The effect of nluric oxide synthase Inhibitors and oxyhaemoglobin on rat striacal dopamine overflow using fast cyclic voleammetry. Br. J. Pharmac. 112: 295p

Black M., Matchews E. and Humprey P. (1994b) The effects; of a photosensitive nluric oxide donor on hasal and eleculcally-stimulated dopamine efflux frorn the rat striatum in vitro. Neuropharmucology 33, Ne 11: 1357.1365

Bohme G., Bon C., Stuumann J., Doble A. and Blanchard J. (1991) Possible Involvement of nitric oxide in long-term potentlation. Eur. J. Pharmoc: 799.379381

Bolam J., Wainer B. and Smith A. (1984) Characterization of cholinergic neurons in the rat neostriatum. A combination of choline acetyltransferase inmunocytochemistry, Golgi-intoregnation and electron microscopy. Neuroscience $12(3)$ : $711.718^{\prime}$

Bonnet P. (1982) Tratado de medicina legal. Ed. EA Aleneo. Buenos Aires

Brann A. and Dikes F. (1977) Efectos de la asfixia intrauterina sobre el neonato a término. Clin Perrinat 4152.154 
Bredt D., Hwang P. and Snyder S. (1990) Locallzation of nitric oxide synthase Indicating a neural role for nitric oxide. Nature 347: $768-770$

Bredt D. and Snyder S. (1994) Transient nitric oxide synthase neurons in embryonic cerebral cortical plate, sensory ganglia and olfactory epithellum. Neuron 13:301.313

Brené S., Lindefors N., Herrera-Marschitz M. and Persson H. (1990) Expression of dopamine D2 receptor and choline acetyltransferase mRNA in the dopamine deafferented rat caudate-putamen. Exp Brain Res 83: $96 \cdot 104$

Buetow K. and Klein S. (1964) Effect of maintenance of "normal"skin temperature on survival of infants of low birth weight. Fediatrics $163-170$

Bunchan A. and Pusinelli W. (1990) Hypothermia but not the N-methyl-D-aspartate antagonist MK. 801 attenuates neuronal damage in gerbils subjected to transient global ischemia. $d$. Neurosci 10. 311316

Bunchan A. and Pulsinelli W. (1991) The N-methyl-D-aspartate MK 801, falls to protect against neuronal damage caused by transient, severe forebrain ischemia in adult rats. $J$. Neurosei $1 \%$ : 1049. 1056

Capani F., Loidl CF., Selvin-Testa A. and Pecci-Saavedra J. (1996) Perinatal asphyxia induces long-term changes in neuronal and astrogltal heat shock proteins expression in the CNS. Soc. Arg. de Ciencies Mort. Šsn Lưs. Ang

Carisson M. and Cartson A (1990) Interactlons between glutamatergic and monaaminergic systems within the basal ganglia. Implications for schizophrenia and Parkinson's disease. Irends in Neurosci 13: 272.276

Carreau A., Duval D., Poignet H., Scatton B., Vlge X. and Nowicki J-P (1994) Neuroprotective efficacy of N-nitro-L-arginine after focal cerebral Ischemla In the mouse and inhlbiton of cortical nitric oxide synthases. Eur J Pharmac 256: 241-249

Cervós- Navarro ]. and Heinrick N. (1991) Selectively vulnerabllity in brain hypoxia. Neurobjology 6/3/3: 149182

Cheramy A., Romo R., Godeheu G., Baruch P. and Glowinsky 1. (1986) In vivo presynaptc control of dopamine release in the cat caudate nucleus. Facilitatory or Inhibitory influence of Lglutamate. Neuroscience 19. 1081-1090

Chleide E., Bruhwyler ]. and Lhikawa K. (1991) Biochemistry of hypoxic damage in brain cells. Roles of energy metabolism, glutamate and calcium ion. Neurosci. 17: 375-390

Chol D. (1990) Cerebral hypoxia: Some new approaches and unanswered quescions. J. Nourosci. 10:2493.2501

Chun ). and Schat C (1989) Interstital cells of the adult neocortical white matter are the remnant of the earty generated subplate neuron population. J. Comp. Neurol 282: $555-569$

Clow D. and Jhamandas K. (1989) Characterization of L-glutamate action on the release of endogenous dopamine from the rat caudate-putamen. J. Phamac. Exp. Ther. 284: 722.728

Colmbra C and Wieloch T. (1992) Hypothermia ameliorates neuronal survival when induced 2 hours after ischemia in the rat. Acto Physiol. Scand 146: 543.544 
Cordey R. (1964) Hypothermia in resuscitating newborns In white asphyxia. Obstetrics \& Gynecology 24(5): $760-767$

Costello A. and Manandhar D. Perinatal asphyxia in less developed countries: annotation (1994) Arch Dis Child 71: $\mathrm{F1.3}$

Dawson T., Bredt D., Fotuhi M., Hwang P. and Snyder S. (1991) Nitrtc oxide synthase and neuronal NADPH dlaphorase are Identical in brain and peripheral tissues. Proc. Natn. Acad. Sci. USA 88. 7797.7801

Dawson V., Dawson T., Bartley D., Uhl E. and Snyder S. (1993) Mechanisms of nittic oxtde medlated neurotoxicity in primary brain cultures. J. Neurosc. 13: 2651.2661

Dawson T. and Snyder S. (1994) Gases as biolodical messengers: nitric oxide and carbon monoxide in the brain. J. Neurosci. 14:5147.5159

Day R., Callguirl L., Kamenski C. and Ehrlich F. (1964) Body temperaure and survival of premature infants. Podiatrics $34: 171 \cdot 181$

Dell'Anna E., Chen Y., Loidl CF., Andersson K., Luthman J., Goiny M., Rawal R., Lindgren T. and Herrera-Marschic M. (1995) Short-term effects of perinatal asphyxia sudied with Fosimmunocytochemistry and in vivo microdlalysis in the rat. Exp. Neurd. 131:279287

Drahota Z., Mourek 1., Rauchova H. and Trojan S. (1991) Molecular and cellular mechanisms involved In the high resistance of neonatal brain to anoxia. In: Molecular basis of neurological disorders and thelr treatment. Edited by Garrod. Chapman \& Hall. London. UK

Drage J., Kennedy C. and Schwartz B. (1964) The Apgar score as an index of neonatal mortallty. A report from the collaborative study of cerebral palsy. Obst \& 6ynec 24/2t: 222-230

Drake P. and Lasek R. (1984) Regional differences in the neuronal cyoskeleton. J. Neurosci 4: 1173.1186

Drejer G., Benveniste H., Diemer N. and Schousboe A. (1985) Cellubr origin of ischemla-Induced gitutamate release from brain tssue in vivo and in vitro. J. Neurochent 45: 145-15i

Dunn J. and MIller ]. (1969) Hypothermla comblned with positive pressure ventilation in resuscleation of the asphyxiated neonate. Am. J. Obs. \& Gynec. 104, 1:58.67

Eng L.F. (1987) Experimental models for astrocye activation and fibrous gliosis. In: Glial-neuronal communications in development and regeneration. NATO AS/ Series H, Cell Biology 1987, Vol 2: 27-40. Springer, New Yorit

Eng L.F. (1988) Astrocytic response to injury. In: Current /ssues in Neural Regenention Research. New Yart, Alan R. Liss, linc, pp 247:255

Erecinska M. and Slwer Y. (1989) ATP and brain function. J. Cenet. Blood Fow Metat. 2.2.19

Faroogul A. Haun S. and Harrocks L. (1994) Ischemia and Hypoxia. In Basi Meurochemisty, 5th Ed, edited by Siegel 6. Raven Press, Ltd, NY, USA 
Ferrante R., Kowall N., Beal M., Richardson E., Bird E. and Martin ). (1985) Selective sparing of a class of striatal neurons in Huntington's disease. Science $230: 561-560^{\circ}$

Floyer J. (1697) An enquiry Into the right use and abuses of the hot, cold, and temperature baths in England, London, Royal Soc, Publisher.

Floyer ). and Baynard E. (1706) The story of cold bathing: both ancient and modern. Landan. Aoyal Soc, Pudlisher.

Gajdusek D. (1985) Interference with axonal transport of neurofilaments as a common pathogenetic mechanism in certain diseases of the central nerwous system. New Engl. L. Mod. $312: 714719$

Garcia ]. (1992) The evolution of brain infarcts. A review. J Neuropatho/ Enp Neurd 51: 387,393

Garthwaite 1. (1991) Glutamate, nitric oxide and cell-cell signaling in the nervous system. Trunds in Neurasci 14: 60-67

Geisler N., Kaufman E., Fisher S., Pleasmann U. and Weber K. (1983) Neurofliament structure combines structural principles of intermedlate filaments with carboxy-terminal extensions increasing in size between triplet proteins. EMBO Jouma/2, 295-302

Gerfen C., Engber T., Mahan L., Susel Z., Chase T., Monsma F. and Sibley D. (1990) DI and D2 dopamine receptor-regulated gene expression of striatonigral and striatopallidal neurons. Science 250: 14291432

Glaquinto S. (1988) Aging and the Nervous System, Wiley, Chichester

Giffard R., Monyer H., Chrlstine C. and Choi D. (1990) Acldosis reduces NMDA receptor actlvation, glutamate neurotoxicity and oxygen-glucose deprivation neuronal injury in cortical culures. Brain Research 506: 339-342

Ginsberg M., Sernau L., Globus M., Dletrich W. and Busto R. (1992) Therapeutic modulation of brain temperature: relevance to ischemic brain injury. Cerebrovase Brain Metabolism Rew 4: 189.225.

Ginsberg M. (1995) Neuroprotection in brain ischemla: An Update (Part I) The Nevrosciemist, Vot 1, 2:95-103

Globus M., Ginsberg M., Dletrich W, Busto R. and Scheinberg P. (1987) Subsuntia nigra lesion protects against ischemic damage in the striaum. Neurosci. Lett. $80: 251.256$

Globus M., Busto R., Dietrich W, Martinez E., Valdes I. and Ginsberg M. (1988) Effect of bcht-. mia on the in vivo release of striatal dopamine, glutamate, and GABA studied by intracerebral microdialysis. J. Neurochem 51: 1455-1464

Globus M., Dletrkch W, Busto R., Valdes I. and Ginsberg M. (1989) The combined treament with dopamine D! Antagonist (SCH 23390) and NMDA receptor blocker (MK 801) dramatically procects against ischemia-Induced hippocampal damage J. Cereb. Blood flow Heiab 8 isupp/ll S5

Goldman S., Pulsinelli W., Clarke W., Kraig R. and Plum F. (1989) The effects of extracellular acidosis on neurons and galia in vitro. J. Cereb. Blood Flow Metab. \&: 471.477

González-Agullar F. \& De Robertis E. (1963) A formalin-perfusion fixation method for histophysiological study of the central nervous system with electron microscope. Neuraiogy 19: 758 IJI 
Graybiel A. (1990) Neurotransmitters and neuromodulators in the basal gandia. Irends in Neurosci 13 17): 244.254

Guevera-Guzman R., Emson P. and Kendrick K. (1994) Modulation of In vivo striatal transmitter release by nitric oxide and cyclic GMP. J. Neurochem. 82: 807-910

Hanbauer I., Wink D., Osawa Y., Edelman G. and Gally J. (1992) Role of nitric oxide in NMDA-evoked release of $3 \mathrm{H}$-dopamine from striatal slices. Neurnepenor 3: 409-412

Hancock M. (1984) Visualization of peptide-immunoreactive processes on serotonin-immunoreactive cefls using two immunoperoxidase staining. J. Histochen Cytochem 32: 311.314

Hansen A. (1985) Effect of anoxia on Ion distribution in the braln. Physiol. Aev. 65: 101.148

Herrera-Marschlt $M$. and Ungerstedt U. (1990) Neuropharmacology and functlonal anatomy of the basal ganglia: Experimental models for Parkinson's and Alzheimer's disease. Adv. Behav. Bioi. 38: $453-458$

Herrera-Marschitz M., Meana J., $O^{\prime}$ Connor WT, Goiny M., Reid M. and Ungerstedt U. (1992) Neuronal dependence of extracellular doparnine, acetylcholine, glutamate, aspartate and GABA measured simultaneously from rat striatum using in vivo microdialysis: reciprocal Interactions. Ams: no Acids 2: 157.179

Herrera-Marschitz M., Loidl CF, Andersson K. and Ungerstedt U. (1993) Prevention of mortality induced by perinatal asphyxia: Hypothermia or glutamate antagonism? Amino Acids 5: 413.419

Heirer-Marschlz M., Loidl CF., You Z-B., Andersson K., Silvelra R., O'Connor WT. and Goiny $M$. (1994) Neurocircuitry of the basal ganglia studied by monitoring neurotransmitter release. Effects of Intracerebral and perinatal asphyctic lesions. Molec. Neurobiol. 3: 171.182

Hess D., Patterson S., Smith D. and Skene J. (1993) Neuronal growth cone collapse and inhibition of proteln fatty acylation by nitric oxlde. Nature $366: 562-565$

Hope B., Michael G., Knigge K. and Vincent S. (1991) Neuronal NADPH diaphorase is a nitric oxide symtethase. Proc. Natn. Acad. Sci. USA 88: 2811.2814

Hill A. (1991) Current concepts of hypoxic-ischemic cerebral Injury in the term newborn. Pediatr Neurol 7: 317.325:

Hossmann K-A. (1991) Animal models of cerebral schemla. Review of literature. Cerebrovasc Dis t (suppel 1):2.15

Hull 1. and Dodd K. (1991) What is birch asphyxia? Commentary of the Br. J. Obstetrics \& Grnaecol. 98. 953.955

Inagaki S., Tagakl H., Suzuki K., Akai F. and Taniquchi N. (1991) Intense immunoreactivity for Mn-superoxide dismutase (Mn-SOD) In cholinergic and non-cholinergic neurons in the rat basal forebrain Brain Res 541: 354357

Johnston M. (1983) Neurotransmitter alterations in a model of perinatal hypoxic-lschemic brain injury. Ame Neurol 13: 500-51!

Judge M., Sheardown M., Jacobsen P. and Honore (1991) Protection against post-lschemic behavioural pachology by the AMPA antagonist NBQX in the gerbil. Neurosci. Lett. 133: 291.294 
Kehr J. and Ungerstedt U (1987) Fast HPLC estimation of $\mathrm{Y}$-aminobutyric acid in microdlalysis perfusates: effect on nipecotic and 3-mercaptopropionic acids. J. Neurnchem 51: 1308-1310

Klosen P. and Van Den Bosh de Aguilar (1994) Phosphorylated neurofilament epitopes in neuronal perikarya in the septum, mesencephalon and dorsal root ganglia of mammals and birds.. of Neurocytology 23: 297.311

Koob (1992) Drugs and abuse: anatomy, pharmacology and function of reward pathways. Trentr in Pharmacel. Sci. 13: $177 \cdot 184$

Kubou Y., Inagaki S, Shirnada S., Kito S., Eckenstein S. and Tohyama M. (1987) Neostriatal chollinergic neurones recelve direct synaptic inputs from dopaminergic axons. Brain Res 413: 179:184

Latov N. et al. (1979) Fibrillary astrocytes proliferate in response to brain injury. Omwlopmenta' Biology 72: 381.384

Lipton S. and Stamler J. (1994) Actions of redox-related congeners of nitric oxide at the NMDA receptor. Neuropharmacology Vol 33, No 11, pp 1229:1233.

Lehmann L. and Langer S. (1983) The striatal cholinergic interneuron: synaptic target of dopaminergic terminals?. Neuroscience $10(4) ; 1105-1120$

Loldl CF., Herrera-Marschl口 M., Andersson K., You Z-B., Goiny M., O'Connor WT., Blelke B. and Ungerstedt U. (1993) Short and long-term effects of perinatal asphyxla in rats monitored with peripheral and intracerebral microdlalysis. AminoAcids, Vol 5, No 1: 167

Loldl CF., Herrera-Marschiz M., Andersson K., You Z-B., Goiny M., O'Connor WT., Sllvelra R., Rawal R., Bjelke B., Chen Y. and Ungerstedt U. (1994) Long-term effects of perinatal asphyxla on basal ganglla neurotransmitter systems studied with microdlalysis in the rat. Nourosci. Lett. 175: 912

LoldI CF., Capani F, López-Costa J]., Selvin-Testa A., López EM. And Peccl Saavedra J. (1996) Striatal cytomegalic neurons-containing nitrk oxide are present In a model of severe perinatal asphyxia. Implications of cold treatment. Medicine (Bs. As.) 56: 169.172

LoldI CF., Capani F., López-Costa J]., Selvin-Testa A., Lopez EM. and Peccl Saavedra J. (1996) Hypothermia prevents chronic NADPH-dlaphorase striatal and cortical alterations in expertmental perinatal asphyxia. Int. J. of Neurosci. (In the press)

Loidl CF., Capani F., Aguirre F., Plehl L., Facorro G., De Paoli T., Hager A. and Peccl Saavedra J. (1996) Free radicals are released in the striatum after reoxygenation in a model of mild and severe perinatal asphyxia. $26^{\circ}$ Soc. for Neurosci. Abstr. Woshington. USA

Lonart G., Cassels K. And Johnson K. (1993) Nitric oxide Induces calchum dependent (3H) dopamine release from striatal slices. J. Neurosci. Res. 35: 192.198

Lowenstein C, Dinerman ]. and Snyder S. (1994) Nitric oxide: a physiologic messenger. Ann. Intern. Med. 120. 227.237

Luth, H-]., Hedlich A, Hibig H, Winkelman E. and Mayer B. (1994) Morphological analyses of NADPH-diaphorase/nitric oxide symthase positive structures in human visual cortex. J. of Necroctiolo g) $23,770-782$ 
Lut P. (1992) Mechanism for anoxic survival in the vertebrate brain. Ann Rev Plysial 54: 601-618

Mann T. \& Elliott R (1957) Neonatal cold injury due to accidental exposure to cold. The Lancet. 1: 229.233

Mann T. (1963) Hypothermla in the newborn. Nursing Times. Jan 4: 15-18

Miller J., Miller F. and Westin B. (1964) Hypothermia in treatment of asphyxia neonatorum. Biol. Neonat 6: 148163

Miller J. (1971) New approaches to preventing brain damage during asphyxia. Am. J. Obstet. \& Gynocal. 110: 1125.1133

Moghaddam B. and Gruen R. (1991) Do endogenous excitatory amino acids Influence suriatal dopamine release? Brain Res 544: 329330

Moncada S., Palmer R. and Higgs E. (1991) Nitric oxide: physlology, pachophyslology and pharmacology. Pharmac. Rev. 43: 109-142

Moncada S. and Higes E. (1993) The L-arginine-nitric oxide phathway. New Engl. J. Med. 329: 2002. 2012

Montague P., Gancayco C., Winn M., Marchase R. and Friedlander M. (1994) Role of NO production in NMDA receptor-mediated neurotransmitter release in cerebral cortex. Science 263: 973 . 977

Mulson E. and Brandabur M. (1994) Sparing of NADPH-dlaphorase strlatal neurons in Parkinson's and Alzheimer's dlseases. Neurofeport 5: 705-708

Naito S. and Ueda (1983) Adenosine-triphosphate dependent uptake of glutamate into protein I-associated synaptical vesicles. J. Biol. Chem. 258: 696-699

Naito S. and Ueda (1985) Characterization of glutamate uptake into synaptic vesicles. $J$. Neurochen. 44: 99.109

Nathaniel E. (1981) The reactive astrocyte. Adv. Cet Neurobiol 2:249.292

Nedegaard M., Goldman S., Desal S. and Pulsinell W. (1991) Acld induced death in neurons and glia. The J. of Neurosci. 11 18: 2489.2497

Nbxon R. \& Sthag R. (1991) Neurofllament phosphorylation: A new look at regulation and function. TWS 14(1): 501.506

Nordlin K. Johansson O., Lindén S. and Hockfelt T. (1993) Glutamate- and aspartate- like immunoreactivities in human normal and inflamed skin. Virchow's Archive B Cal Pathol 64: 75-82

O'Dell T., Hawkins R., Kandel E. and Arancio O. (1991) Tests of roles of two diffusible substances in long-tem potentiation: evidence for nitric oxide as a possible early retrograde messenger. Proc. Notn. Acad. Sei. USA 68. $11285-11289$

Paschen W. (1989) Molecular mechanisms of selective vulnerability of the brain to ischemia. Circ. Metab. Cenveve \&. 115.139 
Pasternak J., Predey T. and Milkhael M. (1991) Neonatal asphyxda: vulnerability of basal ganglla, thalamus, and brainstem. Pedlatr. Nurad. 7. 147.149

Paxinos G. \& Watson C (1986) The rat brain in stereotaxic coordinates. $2^{\prime \prime}$ edilion. Academit Press, New York.

Peng Z., Pietra C., Sbarbati A., Yan X., Zibiani L. and Bentivoglio M. (1994) Induction of NADPH-dlaphorase activity in the rat brain after focal ischemic infarction of the cerebral cortex.

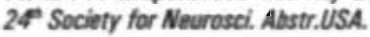

Percy A. (1986) Neonatal asphyda and static encephalopathies. In Pedlatric Neurology. Edited by M. Fishman. Grune \& Stratton. USA

Petito C., Feldmann E., Pulsinell W. and Plum F. (1987) Delayedippocampal damage in humans following cardlorespiratory arrest. Meuroby 37: 1281.1286

Raju A. (1992) Some animals models for the study of perinatal asphyxia. Bio/ Neonate 62: 202.214

Richards D., Obrenovitch T., Symon L. and Curzon G. (1993) Extracellular dopamine and serotonin in the rat striatum during transient ischaemia of different severities: a microdlalysis study, $J$. of Neurochem. 60 (I): $128-136$

Roberts P. \& Anderson S. (1979) Stimulatory effect of L-glutamate and related amino aclds on $(3 \mathrm{H})$ dopamine release from rat striatum: an in vitro model for glutamate action. J. Neurothern. 32: $1539-1545$

Robert-Lewis J., Savaje M., Marcy V., Pinsker L. and Siman R. (1994) Immunolocalization of calpain I-mediated spectrin degradation to vulnerable neurons In the Lschemic gerbil brain. The J. of Neurosci. 14 (6): 39343944

Robinson G., Sinord J., Dowd L. and Kerwin J. (1993) Subtypes of sodium-dependent transport activity: pharmacologic specificity and regulation by sodium and pocasslum. J. Neurochem 60: 167.179

Romijin H., Hofman M. and Gramsbergen A. (1991) At what age Is the developing cerebral cortex of the rat comparable to the full-term newbom human baby? Eorty Humon Dev., 26: 61.67

Rose S., Hindmarsh ]. and Jenner P. (1994) Inhibidon of nlurk oxide synthase enhances NMDAevoked dopamine release in rat striatum in vivo. Br. J. Phermac $11: 59 P$

Samat H. (1992) Cerebral dysgeneses: Embryology and cllnlcal expression, New York. Oxford Universi. ty Press.

Scatton B., Carter C, Benavides ]. and Giroux C. (1991) N-Methyl-D-Aspartate receptor antagoniss: a novel therapeutic perspective for the treatment of Ischemic brain injury. Cerebrovast Dis 1: 121.135

Sheardown N., Nielsen E., Hansen A., Jacobsen P. and Honoré T. (1990) 2,3-Dihydroxy-6nitro-7-sulfamoyl-benzo(F) quinoxaline: a neuroprotecunt for cerebral ischemia. Scimes 247: 571 . 574

Siesjō B. (1978) Brain energy metabolism. John iviey \& Sons, Chichester

Siesjo B. (1988) Mechanisms of ischemic brain damage. Critical care medicine 16: 954963 
Schuman E. Madison D (1991) A requirement for the intercellular messenger nitric oxide in long-term potentiation. Science 254: 1503.1506

Schuman E. \& Madison D (1994) Locally distributed symaptic potentiation in hippocampus. Science 263: 532.536

Silverman W., Fertig J. $\alpha$ Berger A. (1958) The influence of the thermal environment upon the survival of newiy bom premature infants. Pediatrics, 22: 876-886

Smlth M., Auer R. and Sesga B. (1984) The density and distribution of ischemlc brain injury in the rat following 2-10 min of forebrain ischemia. Acta Neuropathol 64: 319.332

Swerdlow N. \& Koob G. (1987) Dopamine, schizophrenia, mania and depression: Toward unified hypothesis of cortico-striato-pallido-thalamic function. Behavioral and' Brain Sciences: 10: 197.245

Tanaka K., Fukuuchi Y., Gomi S., Mihara B., Shirai T., Nogawa S., Nozaki H. and Nagata E. (1993) Inhibition of nitric oxlde synchesis impalrs autoregulation of local cerebral blood flow in the rat.Neuro Report 4:267.270

Terwel D, Nieland L, Schutle B, Reutelingperger C, Ramaekers and Steinbusch H. Differential effects of S-nitroso- $\mathrm{N}$-acerylpenicillamine and sodium nitroprusside on apoptosis in a neuronal cell line as detected by annexin $\vee$ blnding (in preparation)

Thomas E. Pearse A. (1964) The solitary active cells. Histochemical demonstration of damage-resistant nerve cells with a TPN-diaphorase reaction. Acto Neuropath 3: 238.249

Tokutake S., Minaml M., Matsumata M. and Inagakl H. (1993) The effect of organic nitrates on neurogenic release of dopamine: relevance to toxicity of dynamite ingredients in the centrall nervous system. Biogenic Amines 10: 19.25

Tombaugh G. \& Sapoisky R. (1990) Mild acldosis protects hippocampal neurons from injury Induced by oxygen and glucose deprtvation. Brain Res 506: 343.345

Ungerstedt U., Herrera-Marschlu M., Jugnellus U., Stahle L., Tossman U. and Zetterstơom T. (1982) Doparnine symapuc mechanisms reflected in studles combining behavioural recordings and braln dialysis. Adv Biosciences: 37: 219-231

Vannucci R. and Yager J. (1992) Glucose, lactic acid and perinatal hypoxic-ischemic damage. Pediatr Neurol 8: 3.12

Vljayan V., Lee Y. and Eng L. (1990) Increase in glial acidlc protein following neural trauma. Mol. Chem. Neuropothol 13: 107.118

Vincent S. and Hope B. (1992) Neurons that say NO. TWS 15: 108-113

Vinters H., Fisher R., Comford M.et al. (1992) Morphological substrates of infantile sparms: Studies based on surgically resected cerebral tissue. Childs Nerv Syst. \&. \&.17

Volpe ]. (1987) Neurology of the newbom. Philadelphia, Wa Saunders

Walsh P., Jeidekin R., Ells G. (1982) Assestement of neurologic outcome in asplinyiated tenn infants by use of serial CK. BBB isoenzyme measurement. L. Pediatr 101: 988.99\%. 
Westin B., Miller J., Nyberg R. and Wedenberg E. (1959). Neonatal asphyxia pallida treated with hypothermia alone or with hypothermia and transfusion of oxygenated blood. Pudiatnic Surgery 45 (5): 868-879

Westin B., Miller J. and Boles A. (1963) Hypothermia Induced during asphyxiation. Its effects on survival rate, learning and maintenance of the conditioned response in rats. Acta Paediatrica 52: 496

Westin B. (1971) Infant resuscitation and prevention of mentail retardation. Am. d. Obstet. Gynecol. 110: 11341138

World Health Organization (Geneva, 1991). Consultation on birth asphyxia and thermal control of the newborn. Paris, 29.31 July 1989. WHO/MCH/90.6

Young R., Oleginski T., Yagel S. and Towfighi ]. (1983) The effect of grade hypothermia on hypoxic-ischemic brain damage: a neuropathologic study in the neonatal rat. Stroke 14:929-934

Younkin D.P. (1992) Hypoxic-lschemic brain injury of the newbom-statement of the problem and overview. Brain Pathology 2: 209.210

Zhul X. and Luo L. (1992) Effect of nitroprusside (nitric oxide) on endogenous dopamine release from rat striatal slices. $\mathrm{J}$. Neurochem. 59: $932-935$

Zhuo M., Small S., Kandel E. and Hawkins R. (1993). Nitric oxlde and carbon monoxide produce activity-dependent long-term synaptic enhancement in hippocampus. Science 260: 1946.1950 


\section{CURRICULUM VITAE}

The author was born on January 12, 1963 in the city of Buenos Aires, Afgentina. In 1980, he graduated from "Mariano Moreno" Secondary School in Mar del Plata, Argentina. In 1987, he graduated from Medica! School, Universlty of Buenos Aires. During and after his studies, he worked in The Institute of Cell Biology and Neurosciences "Prof. E. De Robertis" under the supervision of Prof. Jorge A. Pecci Saavedra supported by research grants from the UBA (University of Buenos Aires) and CONICET (National Research Council of Argentina).

In the period 1985-1991, he worked with Dr. Luis D'Anna on a model of experimental parkinsonism. In the period 1992-1994, he worked under the supervision of Dr Mario Herrera-Marschiz at the Karolinskal Institute, Stockholm, Sweden, Department of Pharmacology (Prof. Urban Ungerstedt). The data for thls thesls was collected by its author at the Karolinska Institute (1992-1993) and at the Instiurte of Cell Biology and Neurosclences (1994-1995/6) In Buenos Aires, Argentina.

As of June 1996, he works for the Department of Pediatrics under the direction of Prof. Cartos E. Blanco and for the Department of Psychlatry and Neuropsychology under supervision of Dr. Harry W.M. Stelnbusch at the University Hospital Maastricht, The Netherlands. 
92 


\section{Acknowledgements}

I would particularly like to thank Professor Carlos E. Blanco for his support, advice and for giving me the opportunity to present this thesis.

I am grateful to the following for inspiration, teachings and support before and during the writing of this thesis: Professor forge Peccl Saavedra, Dr Mario HerreraMarschitz, Professor Urban Ungerstedt, Dr Kurt. Andersson, Dr Luls D'Anna, Dra Asla Selvin-Testa and Professor Eduardo Mareso.

My gratitude to all the creative friends and colleagues In the scientific environment whom I was lucky to meet in different laboratories and "other places" in the world: Dr Harry M. W. Steinbusch (to whom I am very grateful for the nice welcome he gave me), Dra Ester (Cuti) López (my dear friend), Dr Francisco Capanl, Professor Mario Testa, Dr Juan José (Jj) López-Costa, Emerita (Meri) ]. Vilela de Banchieri, Professor Amanda Pellegrino de Iraldi, Dr Zhi-Bing You, Dr Danilo Gavilanes, Dr Dick Terwel, Dr Gustavo Mallo, Dr Jorge Goldstein, Dra Maria T Igleslas, Martana López, Dr Carlos Tandler, Dra Patricia Tagllaferro, Dr Diego Morita, Dr Fellpe Martinez-Tica, Ing Luls Zlmermann, Dr Rodolfo Silvelra, Dra Beatriz Bolloli, Dr Mlchel Golny, Dr Javler Meana, Dr Bllly O'Connor, Dr Torkel Falkenberg, Jan Gustavsson, Monlca Pace, Dr Jan de Vente, Marjanne Markerink, Hellen Steinbusch, Dr Arjan Blockland, Erlk van DIjk, WII Honig, Dres Fernando and Marisa Ibarra, Dres Carlos and Alejandra Méndez, Dres Alelandro and Angela Bertorello, Dra Graciela Elgue, Marla Rlvadenelra, Dr Martin and Débora Rottemberg, Dra Malra Zapata, Manuel Magrinl, Llz Cortes and Att, Elly Kerkvllet and Edgardo Maza, Susana and Carlos Guarnart-Bernard.

My dear friends Gustavo Macchi, Luis Castillo, José Castillo-Jaluf, Mario Gullé, Daniel Marcos, Hugo Ponce, Dario Martín, Daniel Campana, Gabriel Coen, Jorge Chaparro, Eduardo Martinez and Luis Tetilla.

I thank Marleen Rosbak, Nicole Maes and Imelda Essers, for their help and the nlce environment they created around the computer where I used to write.

I am extremely grateful for the love and affection of my family: my brother Martin, my parents, grandparents, and parents and brothers-In low. To my aunts and uncles, Elba and Jorge and Martha and Claudio.

Finally, I would also like to thank Ruth Waisman for her help with the Inotcate syntax of the English language. 
94

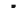

- 


\section{PUBLICATIONS}

\section{This thesis was based in the following papers:}

Loidl CF., Herrera-Marschiz M., Andersson K., You Z-B., Golny M., O'Connor WT., Bjelke B. and Ungerstedt U. (1993) Short and long-term effects of perinatal asphyxia in rats monitored with peripheral and intracerebral microdialysis. AminoAcids, Vol 5, No 1:167

Herrera-Marschitz M., Loidl CF., Andersson K. and Ungerstedt U. (1993) Prevention of mortality induced by perinatal asphyxia: Hypothermia or glutamate antagonism? Amino Acids 5: 413-419

Herrera-Marschit M., Loidl CF., You Z-B., Andersson K., Silveira R., O'Connor WT. and Goiny M. (1994) Neurocircuituy of the basal gang!la studied by mon!toring neurotransmitter release. Effects of Intracerebral and perlnatal asphyctic lesions. Molec. Neurobiol. 9: 171.182

Loidl CF., Herrera-Marschit M., Andersson K., You Z-B., Golny M., O'Connor WT., Silveira R., Rawal R., Bjelke B., Chen Y. and Ungerstedt U. (1994) Longterm effects of perinatal asphyxia on basal ganglia neurotransmitter systems swdied with mlcrodialysls in the rat. Neurosci. Lett. 175: 9.12

Loidl CF., Capanl F, López-Costa J]., Selvin-Testa A., López EM. And Peccl Saavedra ]. (1996) Striatal cytomegallc neurons-containing nltric oxide are present in a model of severe perinatal asphyxia. Implications of cold treatment. Medi. cina. (Bs. As.) 56: $169-172$

Loidl CF., Capani F., López-Costa J]., Selvín-Testa A., López EM. and Peccl Saavedra ]. (1996) Hypothermla prevents chronic NADPH-dlaphorase striatal and cortical alterations in experimental perinatal asphyxla. Int. J. of Neurosci. (In the press)

Loidl CF., Capanl F., López-Costa J]., Selvin-Testa A., López EM., Goldsteln J. and Pecci Saavedra ]. (1996) Short-term changes in NADPH-dlaphorase reactivlty in rat following perinatal asphyxla: Neuroprotective effects of cold treatment (Submitted to Chemical and Molecular Neuropathology)

Capani F., Loidl CF., Selvin-Testa A. and Pecci Saavedra J. (1996) Asphyxia during birth induces astroglial and neuronal Intermediate filament changes in basal ganglia (Submitted) 


\section{Abstracts:}

Short-and-long term effects of perinatal asphyxla studied with microdialysis In rat: Protective effects of hypothermla and glutamate antagonism. Loldl $\mathrm{CF}$, Herrera-Marschlt $M$, Andersson K, Goiny M, O'Connor WT and Ungerstedt $U$. 16th Annual Meating of the European Neuroscience Association. Madrid. Spain. September 1993.

Hypothermla prevents NADPH-dlaphorase striatal and cortical changes Induced by perinatal asphyxia In pups and adult rats. Loldl CF, Capani F, López-Costa J] and Peccl-Saavedra J. 25th Meeting Society for Neurosciences Abstracts. Califomia, USA 1995

Influence of hypothermla In the distribution of nitric oxlde synthase In the strlatum of adult rats subjected to perinatal asphyxla. Capani F, Loidl CF, López EM, Goldsteln ], López Costa J] and Pecci Saavedra J. XV Congreso de la Sociedad Brasileña de Microscopia Electrónica. Caxambú Brasil, Septiembre 1995

Free radlcals are released In the strlatum after reoxygenation in a model of milld and severe perinatal asphyxia. Loldl C.F., Capanl F, Aguirre F, Plehl L, Facorro G, De Paoll T, Hager A. and Pecci Saavedra J. Soc. for Neurosci. Abstr. Washing. ton, USA 1996 
C. F. Loidl' ' Mi. Herrera-Marschitz' , K. Andersson', Z-B. You', M. Goiny' ${ }^{1}$, T. W. O'Connor ${ }^{1}$, B. Bjelke', and U. Ungerstedt'

Departments of 'Pharmacology, and 'Histology and

Neurobiology, Karolinska Institute, ${ }^{2}$ Department of Internal

Medicine, Huddinge Hospital, Stock holm, Sweden

Short- and long-term effects of perinatal asphyxia in rats monitored with peripheral and intracerebral microdialysis

We are developing a novel non-invasive animal model for studying hypoxic-ischemic lesions, similar to those produced under labor in clinical situations. Perinatal asphyxia is induced by maintaining pups-containing uterus horns removed by hysterectomy in a water bath (at $37^{\circ} \mathrm{C}, 30^{\circ} \mathrm{C}$ or $15^{\circ} \mathrm{C}$ ) for various periods of time (0-101 min). Control and asphyctic pups are obtained from the same mother. Following various asphyctic periods, the uterus horns are rapidly opened and the pups are removed and stimulated to breathe by cleaning of the delivery fluid and by tactile stimulation of the oral region. The time of asphyxia is measured from the time when the blood circulation to the uterus is cut of until the pups start to breathe. The umbilical cord is ligated and the animals are allowed to recover on a heating pad. Several parameters are acutely or chronically recorded by direct observation or by in vivo microdialysis. Following asphyxia, pups are impianted subcutaneousily with microdialysis probes in the dorsal region, before they are presented to surrogate mothers. Thus, levels of aminoacids (glutamate, Glu; aspartate, Asp), and metabolic products (lactate, Lact: pyruvate, Pyr) are monitored after delivery in both asphyctic and controls pups.

It was, found that, when the pups were kept in a water bath at $37^{\circ} \mathrm{C}$, neonatal asphyxia led to $100 \%$ mortality within the first. $20 \mathrm{~min}$ period following delivery, whenever the asphyctic period was longer than $22 \mathrm{~min}$. However, when the pups were kept in a water bath at $30^{\circ} \mathrm{C}, 100 \%$ of the pups recovered respiratory function following tactile stimulation and were accepted by the surrogate mothers, even when the pups were exposed to an asphyctic period as long as $41 \mathrm{~min}$. All pups died when the asphyctic period was extended to $50-51 \mathrm{~min}$ At $15^{\circ} \mathrm{C}, 100 \%$ survival was observed following a $101 \mathrm{~min}$ asphyctic period.

Subcutaneous Glu, Asp and Lact levels were increased in all asphyctic gioups, while no significant increases could be seen in Pyr levels. Glu was increased $>4$ fold in all groups, with a maximum increase seen after a $5-6 \mathrm{~min}$ at $37^{\circ} \mathrm{C}$ ( $>10$ fold).

We have completed series of experiments in which the pups were exposed to asphyxia and then, approximately one or six month later, the same rats were implanted with two microdialysis probes, one into the striatum and another into the substantia nigra. Monoamines and amino acids were monitored under basal and D-amphetamine-stimulated conditions. Significant changes in monoamines and GABA were observed in rats exposed to mild and severe asphyxia, while Glu and Asp levels were unchanged. Studies combining microdialysis and immunohistochemistry are

\section{Amino Acids, vol 5 (1) pp 167 (1993)}




\title{
Prevention of mortality induced by perinatal asphyxia: Hypothermia or glutamate antagonism? Short Communication
}

\author{
M. Herrera-Marschitz' ${ }^{1}$ C. F. Loidl ${ }^{1}$, K. Andersson ${ }^{2}$, and U. Ungerstedt ${ }^{1}$ \\ ${ }^{1}$ Department of Pharmacology, Karolinska Institute, and ${ }^{2}$ Department of Internal \\ Medicine, Huddinge Hospital, Stockholm, Sweden
}

Accepted May 18, 1993

\begin{abstract}
Summary. Perinatal asphyxia was induced by keeping pups-containing uterus horns, removed by hysterectonny, in a $37^{\circ} \mathrm{C}$ or a $30^{\circ} \mathrm{C}$ water bath. Asphyxia for a period of $21-22$ min at $37^{\circ} \mathrm{C}$ led to a $97 \%$ mortality within the first $20 \mathrm{~min}$ period following delivery. When the asphyctic period was extended to more than $22 \mathrm{~min}$ all the pups died following delivery. When the asphyxia was induced at $30^{\circ} \mathrm{C}, 100 \%$ of the delivered pups survived and were accepted by surrogate mothers. The piotective effect of hypothermia could be observed even when the pups-containing uterus horns were exposed to a 45-46 min asphyctic period. Pretreatment with dizocilpine $(0.2 \mathrm{mg} / \mathrm{kg}$ s.c.), or 2,3-dihydroxy-6-nitro-7sulfamoyl-benzo(f) quinoxaline (NBQX) $(3-30 \mathrm{mg} / \mathrm{kg}$ s.c.), administered to the mothers one hour before hysterectomy, reduced slightly the mortality induced by a 21-22 min asphyctic period at $37^{\circ} \mathrm{C}$. An increase in survival following a 22-23 min asphyctic period could only be observed after the highest dose of NBQX.
\end{abstract}

Keywords: Amino acids - Asphyxia - Hypothermia - Glutamate receptors - Rat

\section{Introduction}

Acute perinatal asphyxia is a major cause of death and neurological injury in newborn babies. The incidence of asphyxia has been estimated as, 2-4 per 1000 live term births, and has not decreased despite advances in perinatal and obstetric care (Hill, 1991; Younkin, 1992). Many babies die during the newborn period, and $20-30 \%$ of the survivors present long-term neurological deficits (Younkin, 1992). There is evidence that over-activation of excitatory amino acid receptors plays a role in the pathogenesis of perinatal hypoxic-ischernic brain injury, and therefore, it has been suggested that competitive and non-competitive 
N-Methyl-D-Aspartate (NMDA), as well as $\alpha$-amino-3-hydroxy-5-methyl-4isoxazolepropionic acid (AMPA) antagonists are useful as neuroprotective agents (Sheardown et al., 1990; Scatton et al., 1991; Barks and Silverstein, 1992).

We have developed a non-invasive animal model for studying the short-and. long-term consequences of perinatal asphyctic lesions in rats, in conditions similar to those produced under labor in clinical situations (Bjelke et al., 1991). In this study we have analysed the short-term effects produced by asphyxia at $37^{\circ} \mathrm{C}$, and the survival rate following hypothermia or glutamate antagonism.

\section{Material and methods}

Asphyxia was induced in pups-containing uterus horns obtained by cesarean section on pregnant Sprague-Dawley rats. Female rats at the final day of gestation (b.w. 400-500g) were anaesthetised with halothane and hysterectomised. The entire uterus was taken out, the uterus horns containing the foetuses were detached and placed in a $37^{\circ} \mathrm{C}$ or a $30^{\circ} \mathrm{C}$ water bath for various periods of time ( $0-51 \mathrm{~min})$ (control and asphyctic pups could be obtained from the same mother, since each mother produced approximately 15 pups). Following hysterectomy alone or asphyxia, the uterus horns were rapidly opened, the pups were removed and stimulated to breathe on a heating pad by tactile stimulation of the oral region with pieces of medical wipes. The umbilical cord was ligated and after a $60 \mathrm{~min}$ period the pups were given to the surrogate mothers. The time of asphyxia was measured from the time when the blood circulation to the uterus was cut off until the pups started to breathe.

In a series of experiments the non-competitive NMDA antagonist, dizocilpine ( ++$)-\mathrm{MK}$ 801 hydrogen maleate; RBI, Natick, MA, USA) (dissolved in saline) $(0.2 \mathrm{mg} / \mathrm{kg} \mathrm{s.c.)} \mathrm{or} \mathrm{the}$ AMPA antagonist NBQX (Novo Nordisk A/S, Mălov, Denmark, generously suplied by Dr L. Nordholm) (dissolved with a drop of $\mathrm{NaOH}$ in $5 \%$ glucose) $(3-30 \mathrm{mg} / \mathrm{kg}$ s.c.) was administered to the mothers, in a single dose, $1 \mathrm{~h}$ before delivery.

Several parameters were acutely recorded by direct observation at a 40-60 min period following delivery: (1) survival, (2) gasping, and (3) colour of the skin. The reception by surrogate mothers and the survival for at least one month period were also recorded.

Comparisons on the rate of survival was tested by the non-parametric Cochran's test (Q). A level of $P<0.05$ was considered critical for statistical significance.

\section{Results}

Pups delivered from uterus horns removed by hysterectomy from rats at the final day of gestation, started regular breathing (respiratory frequency $\approx 60$ per $\mathrm{min}$ ) almost immediately after delivery was completed. These control pups showed a pink coloured skin and intensive vocalization and motility. They were accepted by surrogate mothers after a $60 \mathrm{~min}$ observation period. When the pups were accepted, they grew up in a manner similar to that shown by normally delivered rats (all the surviving rats reported in this studied were followed up for at least one month period).

Following a 15-16 min asphyctic period, induced in a water bath at $37^{\circ} \mathrm{C}$ (Table $1 \mathrm{~A}$ ) or $30^{\circ} \mathrm{C}$ (Table $1 \mathrm{~B}$ ), $100 \%$ of the pups started breathing short after delivery, they survived and were accepted by the surrogate mothers. Following a 19-20 min asphyctic period at $37^{\circ} \mathrm{C}$ (Table $1 \mathrm{~A}$ ), the pups had to be intensively' stimulated to start to breathe. The surviving pups remained akinetic for a long period after delivery, showed a significant decrease in respiratory frequency $(\approx 20$ per $\mathrm{min}$ ), which was accompanied of gasping, and showed a pink/pale skin. Approximately $30 \%$ of the pups died shortly after delivery. In contrast all the 
Table 1A,B. Short-term effects of neonatal asphyxia performed under $37^{\circ} \mathrm{C}(\mathrm{A})$ and under $30^{\circ} \mathrm{C}$ (B)

\begin{tabular}{lrcc}
\hline $\begin{array}{c}\text { Treatmens } \\
\text { Time of asphyxia }\end{array}$ & S & $\begin{array}{c}\text { Parameters } \\
\mathrm{G}\end{array}$ & $\mathrm{CS}$ \\
\hline $\begin{array}{l}\text { Conitrols } \\
(\mathrm{M}=30 ; \mathrm{N}=30)\end{array}$ & $100 \%$ & No & Pink
\end{tabular}

A.

Asphyxia at $37^{\circ} \mathrm{C}$

$15-16 \min$
$(\mathrm{M}=10 ; \mathrm{N}=96)$

19-20 min

$100 \%$ No Pink

$(\mathrm{M}=10 ; \mathrm{N}=100)$

20-21 min

$(\mathrm{M}=10 ; \mathrm{N}=21)$

21-22 $\mathrm{min}$

$(\mathrm{M}=12 ; \mathrm{N}=100)$

22-23 min

$(\mathrm{M}=10 ; \mathrm{N}=89)$

$30-31 \mathrm{~min}$

$(M=6 ; N=15)$

40-41 min

$(\mathrm{M}=4 ; \mathrm{N}=4)$

45-46 min

$(\mathrm{M}=5 ; \mathrm{N}=8)$

50-51 min

$(M=4 ; N=4)$

$78 \pm 9 \% \quad$ * $83 \% \quad$ Pink/Pale

$40 \pm 16 \% \quad$ - $88 \% \quad$ Pale

$3 \pm 2 \% \quad-100 \% \quad$ Pale

$0 \% \quad * \quad 0 \quad 0$

$0 \% \quad * \quad 0 \quad 0$

$0 \% \quad * \quad 0 \quad 0$

$0 \% \quad$ * $0 \quad 0$

$0 \% \quad+\quad 0 \quad 0$

B.

Asphyxia at $30^{\circ} \mathrm{C}$

$15-16 \mathrm{~min}$

$(\mathrm{M}=3 ; \mathrm{N}=6)$

19-20 min

$(\mathrm{M}=10 ; \mathrm{N}=50)$

20-21 min

$(\mathrm{M}=10 ; \mathrm{N}=40)$

21-22 $\mathrm{min}$

$(\mathrm{M}=10 ; \mathbf{N}=40)$

22-23 min

$(\mathrm{M}=5 ; \mathrm{N}=25$ )

30-31 $\mathrm{min}$

$(\mathrm{M}=6 ; \mathrm{N}=15)$

40-41 min

$(\mathrm{M}=6 \mathrm{i}=15)$

45-46 rnin

$(\mathrm{M}=5 ; \mathrm{N}=15$ )

50-51 min

$(\mathbf{M}=\mathbf{4} ; \mathbf{N}=15)$

$\begin{array}{ccl}100 \% & \text { No } & \text { Pink } \\ 100 \% & 10 \% & \text { Pink } \\ 100 \% & 10 \% & \text { Pink/Pale } \\ 100 \% & 14 \% & \text { Pink/Pale } \\ 100 \% & 20 \% & \text { Pale } \\ 100 \% & 27 \% & \text { Pale } \\ 83 \pm 12 \% & 44 \% & \text { Pale } \\ 46 \pm 5 \% & 100 \% & \text { Pale } \\ 0 \% & 0 & 0\end{array}$

$S$ Survival (Means \pm S.E.M.) $G$ gasping, and CS colour of the skin. $M$ number of mothers; $N$ number of pups. - $\mathrm{P}^{\mathrm{P}}<0.05$, compared with controls. 
pups survived following a $19-20 \mathrm{~min}$ asphyctic period at $30^{\circ} \mathrm{C}$ (Table 1B). The pups started rapidly to breathe in a regular manner, although some initial gasping could be observed. The colour of the skin was similar to that in control pups.

The rate of survival rapidly decreased following prolonged asphyctic periods at $37^{\circ} \mathrm{C}$ (Table $\left.1 \mathrm{~A}\right)$, and as a whole, their physiological condition deteriorated. No pup survived following asphyctic periods longer than $22 \mathrm{~min}$. In contrast, at $30^{\circ} \mathrm{C}$ (Table 1B), all the pups survived up to a 30-31 min asphyctic period, although some signs of physiological impairment (presence of gasping and pale skin) could be observed. Survival could still be observed following a $45-46 \mathrm{~min}$ asphyctic period. No survival was observed following asphyctic periods longer than $46 \mathrm{~min}$.

Table 2. Effect of dizocilpine $(0.2 \mathrm{mg} / \mathrm{kg}$ s.c.) and NBQX (10-30 mg/kg s.c.) (administered to the mother one hour before hysterectomy) on the shortterm effects of neonatal asphyxia at $37^{\circ} \mathrm{C}$. Controls are taken from the respective mother, but without undergoing asphyxia (see legend in Table 1). - $\mathrm{P}<0.05$, compared with the saline group

\begin{tabular}{|c|c|c|c|}
\hline \multirow{2}{*}{$\begin{array}{c}\text { Treatment } \\
\text { Time of asphyxia }\end{array}$} & \multicolumn{3}{|c|}{ Parameters } \\
\hline & $\mathbf{S}$ & G & CS \\
\hline $\begin{array}{l}\text { SALINE } \\
\text { Control } \\
(\mathbf{M}=5 ; \mathbf{N}=5)\end{array}$ & $100 \%$ & No & Pink \\
\hline $\begin{array}{l}21-22 \min \\
(\mathrm{M}=12 ; \mathrm{N}=78)\end{array}$ & $3 \pm 2 \%$ & $100 \%$ & Pale \\
\hline $\begin{array}{l}22-23 \min \\
(\mathrm{M}=5 ; \mathrm{N}=10) \\
\text { DIZOCILPINE }\end{array}$ & 0 & 0 & 0 \\
\hline $\begin{array}{l}\text { Controll } \\
(\mathbf{M}=9 ; \mathbf{N}=9)\end{array}$ & $100 \%$ & No & Pink \\
\hline $\begin{array}{l}21-22 \min \\
(M=9 ; N=42)\end{array}$ & $19 \pm 8 \%$ & $86 \%$ & Pale \\
\hline $\begin{array}{l}22-23 \mathrm{~min} \\
(\mathrm{M}=9 ; \mathrm{N}=30) \\
\mathrm{NBQ} \times 10 \mathrm{mg} / \mathrm{kg}\end{array}$ & $0 \%$ & 0 & 0 \\
\hline $\begin{array}{l}\text { Control } \\
(M=5 ; N=5)\end{array}$ & $100 \%$ & No & Pinl \\
\hline $\begin{array}{l}21-22 \min \\
(\mathrm{M}=5 ; \mathrm{N}=31 \mathrm{l})\end{array}$ & $16 \pm 12 \%$ & $100 \%$ & Pale \\
\hline $\begin{array}{l}22-23 \mathrm{~min} \\
(\mathrm{M}=5 ; \mathrm{N}=28) \\
\mathrm{NBQX} 30 \mathrm{mg} / \mathrm{kg}\end{array}$ & $0 \%$ & 0 & 0 \\
\hline $\begin{array}{l}\text { Control } \\
(M=6 ; N=9)\end{array}$ & $100 \%$ & No & Pink \\
\hline $\begin{array}{l}21-22 \min \\
(M=6 ; N=20)\end{array}$ & $21 \pm 4 \%$ & * $50 \%$ & Pale \\
\hline $\begin{array}{l}22-23 \min \\
(M=6 ; N=23)\end{array}$ & $18 \pm 6 \%$ & $-25 \%$ & Pale \\
\hline
\end{tabular}


Table 2 shows the effect of pretreatment with saline, dizocilpine $(0.2 \mathrm{mg} / \mathrm{kg}$ s.c.) or NBQX (10-30 mg/kg s.c.) (no effects were observed after NBQX $3 \mathrm{mg} / \mathrm{kg}$ s.c.), administered to the mothers, one hour before hysterectomy alone (controls) or hysterectomy followed by $21-22$ or $22-23 \mathrm{~min}$ asphyctic periods at $37^{\circ} \mathrm{C}$. Survival after a $21-22$ min asphyctic period at $37^{\circ} \mathrm{C}$ was slightly increased by pretreatment with dizocilpine or NBQX. An increase in survival following a 22-23 min asphyctic period, at $37^{\circ} \mathrm{C}$, could only be observed after the highest dose of NBQX (30 mg/kg s.c.).

\section{Discussion}

A novel animal model for studying the consequences of perinatal asphyxia in rats is presented. The model is largely non-invasive and it mimicks conditions. similar to those produced under labor in clinical situations (Bjelke et al., 1991). In this report we show the short consequences of various asphyctic periods, focusing on survival, which remains the major goal in any medical intervention.

We found that perinatal asphyxia, induced by immersing pups-containing uterus horns into a water bath at $37^{\circ} \mathrm{C}$ for a period longer than $22 \mathrm{~min}$, led to a $100 \%$ mortality within the first 20 min period following delivery. When the uterus horns were kept in a $30^{\circ} \mathrm{C}$ water bath, $100 \%$ of the delivered pups started respiratory functions following tactile stimulation and were accepted by the surrogate mothers, even when the pups were exposed to a 30-31 min asphyctic period. All pups, however, died when the asphyctic period was extended to 50-51 min. The pups surviving prolonged asphyctic periods showed several signs of physiological impairment (e.g. decrease in respiratory frequency, motility and vocalization, and changes in the colour of the skin), however, they were accepted by surrogate mothers and survived for at least one month.

The striking protective effect of hypothermia shown in the present study is in agreement with the report by Ginsberg et al. (1992) demonstrating that low intraischenaic brain temperature can protect brain neurons in rats subjected to transient forebrain ischemia, an effect probably due to reduction in brain energy demands and to a consequent decrease in the rate of ATP depletion (Young et al., 1983). The protective effect of hypothermia has been utilized world wide: among primitive peoples and its effect on survival following asphyxia was pionerly studied by J.A. Miller and collaborators in the fifthies (see Miller, 1971).

It has been suggested that competitive and non-competitive NMDA, as well as AMPA antagonists are useful as neuroprotective agents in focal and global ischemia (Sheardown et al., 1990; Scatton et al., 1991; Barks and Silverstein, 1992). Thus, it was interesting to compare the protective effect of hypothermia. with that of glutamate antagonists. In a series of experiments (Loidl et al. in preparation) it was found that dizocilpine given in doses above $0.5 \mathrm{mg} / \mathrm{kg} \mathrm{s.c.,}$ was lethal to the pups delivered by hysterectomy. A $100 \%$ survival was observed after $0.3 \mathrm{mg} / \mathrm{kg}$ s.c. of dizocilpine, however, they were not accepted by the surrogate mothers. However, following dizocilpine $0.2 \mathrm{mg} / \mathrm{kg}$ s.c. the pups were also accepted by the surrogate mothers. In the present study it was found that dizocilpine $(0.2 \mathrm{mg} / \mathrm{kg}$ s.c.) could slightly increase survival induced by a 21-22 min asphyctic period at $37^{\circ} \mathrm{C}$ (from $3 \%$ to $19 \%$ ). However, no protective effect 
could be observed against longer asphyctic periods. In view of a report by Judge et al. (1991), demonstrating a protective effect of the AMPA antagonist NBQX, we also tested this drug in order to increase survival following asphyxia. NBQX, at the dose of $30 \mathrm{mg} / \mathrm{kg}$ s.c., increased survival following $21-22 \mathrm{~min}$ (from. $3 \%$ to $21 \%$ or $22-23$ (from 0 to $18 \%$ ) asphyctic periods (Table 2 ). No signs of protection were observed on pups suffering from longer than $23 \mathrm{~min}$ asphyctic periods (data not shown).

Thus, the present results suggest a preventive effect by the glutamate antagonists. The effect is, however, minor as compared with the prominent effect produced by hypothermia. Higher doses of dizocilpine are clearly toxic to the pups, and therefore cannot be tested. Higher doses of NBQX, as well as more specific and selective glutamate antagonists should be studied. However, whatever the results might be, the effects of the drugs should be compared with those produced by hypothermia.

In conclusion, a new non-inivasive model for studying perinatal asphyxia is presented, which allows to study the short- and long-term consequences of hypoxic-ischemic lesions in rats, induced under conditions similar to those found under labor in clinical situations. Hypothermia appears to be superior to glutamate antagonism as a therapeutical intervention for increasing survival following perinatal asphyxia. Survival remains the most important goal of medicine, and therefore it should be considered when different therapeutical approaches are studied and should be compared with the effects of hypothermia.

\section{Acknowledgement}

This study was supported by grants from the Swedish Medical Research Council (8669. 10362), Karolinska Institute Research Funds, the fundations of Ake Wiberg. Magnus Bergvall, Loo och Hans Osterman, Harald and Greta Jeansson, and Samariten, and Swedish Tobacco Research Funds. C.F.L. is a recipient of a BID-CONICET (Argentina) fellows hip.

\section{References}

Barks JDE. Silverstein FS (1992) Excitatory amino acids contribute to the pathogenesis of perinatal hypoxic-ischemic brain injury. Brain Pathology 2: 235--243

Bjelke B, Andersson K, Ögren S-O, Bolme P (1991) Asphyctic lesion: proliferation of tyrosine hydroxylase-immunoreactive nerve cell bodies in the rat substantia nigra and functional changes in dopamine neurotransmission. Brain Res 543: 1-9

Ginsberg MD, Semau LL, Globus MY-T, Dietrich WD, Busto R (1992) Therapeutic modulation of brain temperature: relevanoe to ischemic brain injury. Cerebrovasc Brain Metab Rev 4: 189-225

Hill A (1991) Current concests of hypoxic-ischemic cerebral injury in the term newborm. Pediatr Neurol 7: 317-325

Judge ME, Sheardown MJ, Jacobsen P, Honoré T (1991) Protection against post-ischemic behavioral pathology by the $\alpha$-amino-3-hydroxy-5-methyl-4-isoxazolepropionic acid (AMPA) antagonist 2,3-dihydroxy-6-nitro-7-sulfamoyl-benzo(f) quinolaxine (NBQX) in the gerbil. Neurosci Lett 133: 291--294

Miller JA (1971) New approaches to preventing brain damage during asphyxia. Am J Obstet Gynecol 110: 1125-1133

Scatton B, Carter C, Benavides J, Giroux C (1991) N-Methyl-D-Asprartate receptor antagonists: a novel therapeutic perspective for the treatment: of ischemic brain injury. Cerebrovasc Dis 1: :21-135 
Sheardown MJ, Nielsen EO, Hansen AJ, Jacobsen P, Honoré T (1990) 2,3-Dihydroxy-6nitro-7-sulfamoy!-benzo(F)quinoxaline: a neuroprotectant for cerebral ischemia. Science 247: $571-574$

Young RSK, Oleginski TP, Yagel SK, Towfighi J (1983) The effect of grade hypothermia on hypoxic-ischernic brain damage: a neuropathologic study in the neonatal rat. Stroke 14: 929-934

Younkin DP (1992) Hypoxic-ischemic brain injury of the newborn-statement of the problem and overview. Brain Pathology 2: 209-210

Authors" address: M. Herrera-Marschitz Ph.D., M.D, Department of Pharmacology, Karolinska Institute, Box 60 400, S-104 01 Stockholm, Sweden.

Received Apri] 1, 1992 


\title{
Long-term effects of perinatal asphyxia on basal ganglia neurotransmitter systems studied with microdialysis in rat
}

\author{
C.F. Loidla, M. Herrera-Marschitz", K. Andersson', Z.-B. You", M. Goiny, W.T. O'Connor", \\ R. Silveira", R. Rawal", B. Bjelke ${ }^{b}$, Y. Chen", U. Ungerstedt" \\ Departments of "Phyriology and Pharmacology and 'Internal Mediche (Huddinge Hospital), Karolinska Inutifute, S-17I77 Siockholm, Sweden
}

Received 17 February 1994; Revised verion received 6 May 1994; Accepted 6 May 1994

\begin{abstract}
Asphyxia was induced in pups delivered by caesarean section on pregnant Sprague-Dawley rats. Rats within the last day of gestation were anaesthetised and hysterectomized. The uterus horns including the foetuses were placed in a water bath for various periods of time. Following asphyxia the uterus horns were opened. The pups were removed, stimulated to breathe, left to recover and given to surrogate mothers. Control and asphyctic pups were obtained from each mother. Rats surviving asphyctic periods longer than $20 \mathrm{~min}$ at $37^{\circ} \mathrm{C}$ showed chronic deficits in the release of neurotransmitters monitored with microdialysis in the basal ganglia. The main change observed in 6-rnonth-old male rats that underwent severe perinatal asphyxia was a marked decrease in striatal dopamine release, monitored under basal and D-amphetamine stimulated conditions, as cornpared with control (normal- or caesarean-delivered) rats. Striatal glutamate and aspartate levels were also decreased following asphyxia. In the substantia nigra, the main effect of asphyxia was a decrease of both $\gamma$-aminobutyric acid (GABA) and aspartate levels. Thus, this study provides evidence that perinatal asphyxia leads to chronic deficits in neurotransmission in the basal ganglia.
\end{abstract}

Key words: Neonatal asphyxia; Basal ganglia; Dopamine; Parkinson's disease; Microdialysis; Ageing; Rat

Acute perinatal asphyxia can be a cause of deatb and neurological injury in newborn babies [8]. Many asphyctic babies die during the newborn period, and 20-30\% of the survivors present long-term neurological sequelae, including Attention Deficit Hyperactivity Dis. order, Cerebral Palsy, Seizures and Mental Retardation [15]. Although there is agreement that dopaminergic transmission decreases with age, and that this decrease is enhanced in several neurodegenerative disorders, such as Parkinson's and Alzheimer's diseases [4], it is nol known whether perinatal asphyxia is related to the biochemical features observed in such accelerated ageing processes. It is our hypothesis that, e.g. decreases in dopamine (DA) levels observed at the adult stages might be related back to perinatal asphyctic lesions.

Several models have been used to study severe ischernia, but the majority of them are invasive and per-

\footnotetext{
"Corresponding author. Fax: (46) (8) 32-4969.
}

formed in one-week-old or older pups $[9,11]$. At the Karolinska Institute, a novel non-invasive model for studying the short- and long-term consequences of hypoxic-ischemic lesions in rats, has been developed. Asphyxia is induced during delivery, mimicking the conditions resulting in asphyxia in human labor $[3,6]$. However, it should be kept in mind that the use of one-weekold or older pups is prefered by many scientists [14], since there is evidence showing that, at that age, the maturation grade of the rat cerebral cortex best matches that of the full-term newborn human baby [12]. It is not clear, bowever, whether this period is also optimal for studying other brain regions. Nevertheless, in the present model asphyxia is induced at the time when the rats do normally deliver.

The obvious and most serious short-term consequence of perinatal asphyxia observed in the present study was mortality. At $37^{\circ} \mathrm{C}$, an asphyctic period longer than 22 min was inevitably associated with death. Rats surviving asphyctic periods longer than $20 \mathrm{~min}$ at $37^{\circ} \mathrm{C}$ showed 
chronic deficits in several putative neurotransmitter systems monitored with microdialysis [13] in the basal ganglia.

Asphyxia was induced in pups delivered by caesarean section on pregnant Sprague-Dawley rats. Rats within the last day of gestation were anaesthetised with ether and hysterectomized. The gestational age of the rat was determined by estabularium protocols and by clinical palpation. The entire uterus, still containing the foetuses, was taken out, the uterus horns were detached and placed in a water bath at $37^{\circ} \mathrm{C}$ for various periods of time. Caesarean-delivered control and asphyctic pups were obtained from the same mother, since each mother delivered approximately $12-15$ pups. Following asphyxia, the uterus horns were rapidly opened and the pups were removed and stimulated to breathe on a heating pad by cleaning of the delivery fluid and by tactile stimulation of the oral region with pieces of medical wipes. The umbilical cord was ligated and the animals were left to recover for $40-80 \mathrm{~min}$ before they were given to surrogate mothers. Several parameters were recorded by direct observation at a $40-80 \mathrm{~min}$ period following delivery: (i) body weight, (ii) survival, (iii) respiratory frequency, (iv) gasping, (v) vocalisation, (vii) colour of the skin, and (viii) spontaneous movements (Table 1). Rats which had normally delivered $24 \mathrm{~h}$ before the experiments were utilised as surrogate mothers. Each surrogate mother conserved two of its own male pups and received four asphyctic and two caesarean delivered control male pups. After six months $(=500 \mathrm{~g}$ b.wt.), asphyctic and control rats were anaesthetised with halothane, placed in a Kopf stereotaxic frame and implanted with two microdialysis probes, one into the left striatum (coordinates: B $0.5, \mathrm{~L}-3.2, \mathrm{~V}-7.2$, according to the atlas of Paxinos and Watson [10] (dialysing. length $=4 \mathrm{~mm}$; diameter $=0.5 \mathrm{~mm})(\mathrm{CMA}$ microdialysis $A B$, Stockholm, Sweden) and another into the left substantia nigra (B $-6.2, \mathcal{L}-7.6, \mathrm{~V}-8.6$; inserted with a $40^{\circ}$ angle from vertical in the coronal plane) (dialysing length $=2 \mathrm{~mm}$; diameter $=0.3 \mathrm{~mm}$ ). The microdialysis probes were perfused with a modified CSF solution $(148 \mathrm{mM} \mathrm{NaCl}, 2.7 \mathrm{mM} \mathrm{KCl}, 1.2 \mathrm{mM} \mathrm{CaCl}, 0.85 \mathrm{mM}$ $\mathrm{MgCl}_{2} ; \mathrm{pH} 7$ ). A constant flow of $2 \mu \mathrm{V} / \mathrm{min}$ was maintained with a microdialysis pump. Halothane anaesthesia was maintained throughout the microdialysis experi- ment by free breathing into a mask fitted over the nose of the rat ( $1 \%$ halothane in air flow of $1.5 \mathrm{Vmin}$ ). Body temperature was kept at $37^{\circ} \mathrm{C}$ using a temperature control system. Samples (collected every $40 \mathrm{~min}$ ) were directly injected onto high performance liquid chromatography systems, coupled to electrochemical detection (HPLC-EC) systems for DA and its metabolites and $\gamma$ aminobutyric acid (GABA), or to a fluorometric detection system for glutamate (Glu) and aspartate (Asp) (see [5]). The microdialysis probes used in this study showed approximately $20 \%$ and $14 \%$ in vitro recovery in $4 \mathrm{~mm}$ and $2 \mathrm{~mm}$ long probes, respectively, for DA, dihydroxyphenylacetic acid (DOPAC), homovanillic acid (HVA), GABA, Glu and Asp (expressed as the concentrations found in the perfusates; $n M$ ). Basal values are referred to those obtained before the administration of $2 \mathrm{mg} / \mathrm{kg}$ s.c. of D-amphetamine ( $200 \mathrm{~min}$ after microdialysis implantation). Means and standard errors of the means (S.E.M) were calculated and differences were tested with Fisher $(F)$-ANOVA test. A level of $P<0.05$ for the two-tailled test was considered critical for statistieal significance.

As shown in Table 1, 14\% of the pups survived a 20-22 min asphyctic period. The surviving pups showed deficits in respiration and were largely akinetic. However, all the pups were accepted by the surrogate mothers. Following weaning, the animals were housed in groups of three or four per cage; at that stage no obvious estabularium differences were observed between control and asphyctic rats.

Table 2 shows DA, metabolites and amino acid levels found in the striatum (A) and substantia. nigra (B) of control (caesarean-delivered) and asphyctic rats 6 months following delivery. No significant differences were observed between normal and caesarean-delivered rats, and therefore values obtained in normal rats are not shown. A significant decrease in striatal DA $(=60 \%)$, Glu $(-80 \%)$ and Asp $(-50 \%)$ levels was observed in the asphyctic rats (Table 2A). In the substantia nigra, no significant changes were observed in DA levels, although HVA were significantly increased $(-70 \%)$ in the asphyctic rats. In this region, the most marked effects were seen on GABA and Asp levels, which were decreased by $=50 \%$ and $=80 \%$, respectively (Table $2 B$ ). The time course of the effect of D-amphetamine on striatal DA

Table 1

Short-term effects of Severe perinatal asphyxia, monitored by direct observation at the $40-80$ min period following delivery

\begin{tabular}{|c|c|c|c|c|c|c|c|}
\hline Experimental condition & $\begin{array}{l}\text { Body weight } \\
\text { (g) }\end{array}$ & Survival & $\begin{array}{l}\text { Respiratory } \\
\text { frequency }\end{array}$ & Gasping & Vocalization & $\begin{array}{l}\text { Colour of } \\
\text { the skin }\end{array}$ & $\begin{array}{l}\text { Spontaneous } \\
\text { movements }\end{array}$ \\
\hline [1] Normal delivery $(n=18)$ & $6.1 \pm 0.5$ & $100 \%$ & $79 \pm 2$ & $0 \%$ & $100 \%$ & Pink & $3.9 \pm 0.1$ \\
\hline [2] Caesarean detivery $(n=42)$ & $5.8 \pm 0.5$ & $100 \%$ & $74 \pm 2$ & $0 \%$ & $100 \%$ & Pink & $3.8 \pm 0.1$ \\
\hline [3] 20-22 min asphyxia $(n=36)$ & $5.8 \pm 0.5$ & $14 \%$ & $21 \pm 3$ & $98 \%$ & $0 \%$ & Pale & 0 \\
\hline
\end{tabular}

Spontaneous movements were scored by the following scale: $(0)$ akinesia and ripidity (mainly of hind legs); (1) movemeet of one of the following body structures: ffont legs, hind legs or bead alone; (2) movement of two of the body structures; (3) movement of all body structurex; (4) intensive movements shown by wriggling. Gasping refers to an effort to maintain respiration shown by opening of the mouth and movements of the diaphragm. 


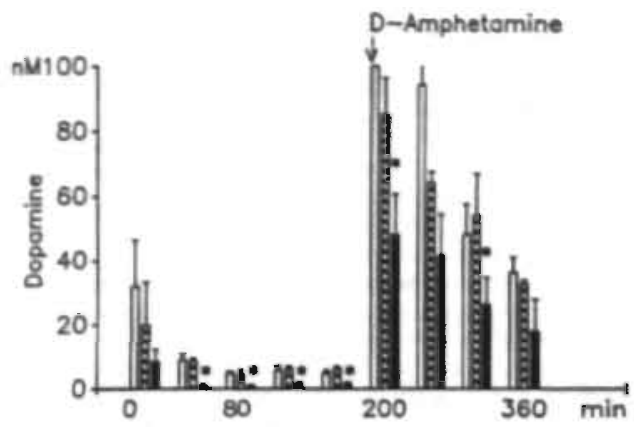

Fis 1. Effect of severe perinatal asphyxia oa striatal extracellular dopamine levels measured approximately six months after delivery. Mierodialysis probes were implanted into the striatum of: (1) normal(open columns, $n=8$ ), and (2) caesarean-delivered control (crosshatched columns, $n=8$ ) rats, as well as of (3) asphyctic (6lled columns; $n=8$ ) rats. Two-hundred minutes after the microdialysis implantation, a dove of D-amphetamine ( 2 mg/kg s.c.) was administered. Dopamine mas assayed in $20 \mu$ samples using HPLC-EC. Vertical lines sbow S.E.M. $=P<0.05$ for the two-talied test.

levels in control and asphyetic rats is shown in Fig. 1. For comparison, striatal DA levels found in normal rats are also presented. Compared to levels in caesareandelivered rats, the D-amphetamine effect on DA levels was decreased by $\approx 40 \%$ in asphyctic rats.

The obvious and most serious short-term consequence of perinatal asphyxia is death. We have recently reported [6] that the rate of survival after perinatal asphyxia is dependent upon the duration of the asphyxia, as well as upon the temperature at which it occurs. At $37^{\circ} \mathrm{C}$, the normal condition, $100 \%$ survival is observed up to a 16 $\min$ asphyctic period, whilst asphyctic periods longer than $22 \mathrm{~min}$ are inevitably associated with $100 \%$ mortality. However, a $100 \%$ survival is still observed up to a 30 min asphyctic period at $30^{\circ} \mathrm{C}$, and even up to a $100 \mathrm{~min}$ asphyctic period at $15^{\circ} \mathrm{C}$.

Rats surviving asphyctic periods longer than $20 \mathrm{~min}$ showed chronic deficits in the release of several putative neurotransmitters monitored with microdialysis in the basal ganglia. The main change observed in six month old rats that underwent severe perinatal asphyxia was a marked decrease in dopamine release, monitored under basal and D-amphetamine stimulated conditions, as compared with control (normally- or caesarean-delivered) rats. In agreement with the present observation of a reduced dopamine release in the neostriatum, and reduced GABA release in the substantia nigra, parallel experiments showed that following severe perinatal asphyxia, rats presented a decrease in the rate of spontaneous locomotor activity [1]. Whether the chronic effect on DA release is primarily due to perinatal asphyxia or secondary to other neurotransmitter systems is not yet known. However, in a recent study [2], changes in the number of tyrosine-hydroxylase (TH) immunoreactive nerve cell bodies, as well as in basic Fibroblast Growth Factor (FGF) gene expression were observed in the substantia nigra of asphyctic rats, four weeks after birth. Furthermore, we have recently found that severe perinatal asphyxia produced a decrease in DA levels and DA turnover in the striatum, but not in the substantia nigra, measured postmortem at the adult stage (Ungethum et al., in preparation). The effect of perinatal asphyxia on DA levels appears to depend upon the length of the asphyctic period, since we have found that following sub-severe asphyxia $\left(19-20 \mathrm{~min}\right.$, at $\left.37^{\circ} \mathrm{C}\right)$, basal extracellular DA levels were significantly increased $(-2$ fold $)$, although the effect of D-amphetamine was significantly decreased $(=50 \%)$ [7]. Furthermore, a decrease in the total number of neurons in hippocampal (CAI, CA3) regions, which may contribute to the general behavioural syndrome observed after perinatal asphyetic lesions, has

Table 2

Loes-term effects of Severe perinatal asphyxia (ix monthi after delivery) on monoamine and amino acid leveis monitored under basal (160$200 \mathrm{~min}$ period following microdialynis implantation) and $D$-amphetamine-stimulated (2 me/kg s.c.) (200-240 min period) conditions in the striatum (A) and substantin nigra (B) of caesarean delivered (controi) and asphyctic ( $>201 \mathrm{~min}$ asphyxia before delivery) rats.

\begin{tabular}{|c|c|c|}
\hline & Basal (nM) & D-Amphetamine $(\mathrm{n} / \mathrm{M})$ \\
\hline \multicolumn{3}{|c|}{ (A) Striatum: } \\
\hline \multicolumn{3}{|c|}{ Control $(n=15-22)$} \\
\hline Dopamine & $4.2 \pm 1$ & $72.4 \pm 9$ \\
\hline DCPAC & $1175 \pm 115$ & $779 \pm 95$ \\
\hline HVA & $1052 \pm 154$ & $923 \pm 133$ \\
\hline GABA & $22 \pm 3$ & $27 \pm 5$ \\
\hline Glutamate & $1203 \pm 281$ & $1322 \pm 321$ \\
\hline Asparate & $133 \pm 30$ & $101 \pm 33$ \\
\hline \multicolumn{3}{|c|}{ Asphycric $(n=4-8)$} \\
\hline Dopamine & $1.6 \pm 0.4^{b}$ & $48.1 \pm 13^{*}$ \\
\hline DOPAC & $1239 \pm 175$ & $818 \pm 129$ \\
\hline HVA & $773 \pm 88$ & $694 \pm 77$ \\
\hline GABA & $21 \pm 3$ & $25 \pm 2$ \\
\hline Glutamate & $230 \pm 40^{6}$ & $22 \pm \pm 51^{\circ}$ \\
\hline Aspartute & $61 \pm 10^{b}$ & $120 \pm 60$ \\
\hline \multicolumn{3}{|c|}{ (B) Substantia nigra } \\
\hline \multicolumn{3}{|c|}{ Control $(n=16-24)$} \\
\hline Dopamine & $0.9 \pm 0.1$ & $1.7 \pm 0.3$ \\
\hline DOPAC & $14 \pm 2$ & $4 \pm 3$ \\
\hline HVA & $38 \pm 8$ & $30 \pm 7$ \\
\hline GABA & $19 \pm 3$ & $34 \pm 11$ \\
\hline Glutamate & $788 \pm 201$ & $781 \pm 232$ \\
\hline Apparate & $91 \pm 20$ & $80 \pm 10$ \\
\hline \multicolumn{3}{|c|}{ Asphyctic $(n=48)$} \\
\hline Dopamine & $0.6 \pm 0.2$ & $1.5 \pm 0.3$ \\
\hline DOPAC & $20 \pm 7$ & $17 \pm 6$ \\
\hline HVA & $65 \pm 5$ & $64 \pm \theta$ \\
\hline GABA & $9 \pm 2$ & $11 \pm 2$ \\
\hline Glutamate & $991 \pm 150$ & $940 \pm 160$ \\
\hline Aspartate & $11 \pm 2^{b}$ & $11 \pm 2^{*}$ \\
\hline
\end{tabular}

$t=P<0.05$ compared to the corresponding values observed in the controls. 
also been reported [3]. Further studies combining microdialysis, immunohistochemistry and quantitative histofluorometry are now in progress.

Thus, the present experimental model appears to be useful to study the short- and long-term consequences of hypoxic-ischemic lesions in rats, induced under conditions similar to those found during a human labor resulting in an asphyctic state. Asphyxia during birth may be a factor contributing to the development of neurodegenerative diseases such as Parkinson's and Alzheimer's dis. eases.

This study was supported by grants from the Swedish Medical Research Council (8669, 10362), Karolinska Institutet Fonder, the Swedish Society of Medicine, Mag. nus Bervall's Stiftelse, the Swedish Tobacco Research Council, and the Stanley Foundation, US.A. Z.-B.Y. is a recipient of a Karolinska Institute-Guest Scientist Fellowship, Stockholm, Sweden; C.F.L. was a recipient of a CONICET Fellowship, Argentina, and R.S. was a recipient of a IPICS Fellowship, Uppsala, Sweden.

[1) Andersson, K., Bjelke, B., Bolme, P, and Ögren, S.O., Asphyxiainduced lesion of the rat hippocampus (CA1, CA3) and of the nigro-striatal dopamine system. In J. Gross (Ed.). Hypoxia and Ischemia, Vol. 41, CNS, Wissenschafliche Publikationen der Humboldt-Univernitat zu Berlin, Berlin, 1992, pp. 71-76.

(2) Andersson, K., Blum, M. Chen, Y., Eneroth, P., Gross, J., Ungethum, U., Bjelke, B., Diaz, R., Herrera-Marschitz, M., Jamison, L., Loidl, F., Astrôm, G. and Ögren, S.O., Asphyxia during birth results in an increase in bFGF gene expression concomitantly with an increase in the number of dopamine nerve cell bodies in the substantis nigra in the 4 week old rat, submitted.

[3] Bjelke, B., Andersson, X. Ogren, S.O., Bolme, P., Asphyctic lesion: proliferation of tyronine hydroxylase-immunoreactive nerve cell bodies in the rat substantia nigra and functional changes in dopamine neurotransmission, Brain Res., 543 (1991) 1-9.
[4] Giaquinto, S., Aging and the Nervous System, Wiley, 1988, Chichester.

[5] Herrera-Marschitz, M., Meana, J.J., O'Connor, W.I, Goiny, M, Reid M.S., Ungerstedt, U., Neturosal dependence of extracellular dopamine, acetylcholine, glutamate, aspartate and gammaaminobutyric acid (GABA) measured singulianeously from rat neostriatum using in vivo microdialysis: reciprocal interactions, Amino Acids, 2 (1992) 157-179.

[6], Herrera-Marschitz, M., Loidl, C.F., Andersson, K. Ungerstedt, U. Prevention of the mortality induced by perinatal asphyxia: hypothermia or glutamite antigonisrn? Amino Acids, 5 (1992) 413-419.

[7] Herrera-Marschitz, M., Loidl, C.F., You, Z-B., Andersson, K Silveira, R. O'Connor, W.T. and Goiny, M., Neurocireuitry of the basal ganglia studied by monitoring neurotransmitter release: effects of intracerebral and perinatal asphyctic lesions, Mol. Neurobiol., in press.

[8], Hill, A., Current concepts of hypoxio-ischemic cerebra! injury in the term nesuborn, Pediutr. Neurol. 7 (1991) 317-325.

[9] Hossmann, K-A., Animals models of cerebral ischemia Review of literature, Cerebrovasc. Dis., I (Suppl. 1) (1991) 2-15.

[10] Painos, G. and Watson, C. The Rat Brain in Stereotaxic Coordinates, Academic Press, 1982, New York.

[il] Raju, T., Some animals modeis for the study of perinatal asphyxia, Biol. Neonate, 62 (199:2) 202-214.

[12] Romijin, H.J. Hofman, M.A. and Gramsbergen, A., At what age is the developing serebral cortex of the rat comparable to the full-term newborn human baby? Early Human Dev., 26 (1991) $61-67$.

[13] Ungerstedt, U., Herrera-Marschitz, M., Jungnelius, U., Sthle, L. Tossman, $U$. and Zetterstrôm. T., Dopamine synaptic mechanisms reflected in studies combining behavioural recordings and brain dialysis, Adv. Biosci., 37 (1982) 219-231.

[14] Vannucci, R.C and Yager, J.Y., Glucose, lactic acid and perinatal hypoxic-ischemic brain damage, Pediatr. Neurol., 8 (1992) 3-12.

[15] Younkin, D.P., Hypoxic-ischemic brain injury of the newborn -statement of the problem and overview, Brain Pethol., 2 (1992) 209-210. 


\title{
Neurocircuitry of the Basal Ganglia Studled by Monitoring Neurotransmitter Release
}

\section{Effects of Intracerebral and Perinatal Asphyctic Lesions}

\author{
Mario Herrera-Marschitz, "1 C. Fabián Loidl, ${ }^{1}$ \\ Zhi-Bing You, ' Kurt Andersson, ${ }^{2}$ Rodolfo Silvelra,' \\ Witliam T. O'Connor,' and Michel Goiny'
}

'Department of Pharmacology, Karolinska Institutet;

and 'Department of internal Medicine, Huddinge Hospøtal, Stockholm, Sweden

\begin{abstract}
The neurocircuitries of the basal ganglia are studied with in vivo microdialysis, with special consideration to dopamine transmission and its interaction with other neurotransrnitter systems. The aim is to develop experimental models to study the pathophysiology and therapy of neurodegenerative disorders of the basal ganglia, as well as to develop models to study the short- and long-term consequences of perinatal asphyctic lesions. A main goal of these studies is to find and to characterize new treatments for these disorders.
\end{abstract}

Index Entries: Basal ganglia; neurotransmitter release; microdialysis; chemical lesians; asphyxia; hypothermia; rats.

\section{Introduction}

In this article, we present our recent investigations about the neurocircuitry of the basal ganglia. The aims of these investigations have been:

1. To study the neurocircuitry and neuropharmacology of the basal ganglia, with special consideration to dopamine (DA) transmission and its interaction with other neuromal systems;

2. To develop experimental models to study the pathophysiology of neurodegenerative disorders of the basal ganglia;

3. To study new pharmacological approaches for the treatment of these disorders; and

4. To develop a novel model to study the shortand long-term consequences of perinatal asphyctic lesions.

The basal ganglia provide a complex neuronal network that conveys and integrates signals from and to the cerebral cortex. Neurocircuitries of the basal ganglia have been associated with several neurodegenerative diseases. Thus, it is well established that in Parkinson's clisease degeneration of the rigrostriatal DA system constitutes the most critical abnormality. In Huntington's chorea the most prominent feature is a marked loss of

"Authoir to whom all correspondence and reprint requests; should be addiressed. 
striatal neurons. However, although Alzheimer's disease and dementia of Alzheimer's type are primarily associated with deficits of cerebral cortex and hippocampal formation, some of the symptoms presented by these diseases are also linked to dysfunctions of the basal ganglia (1). Furthermore, deficits of mesolimbic and mesocortical DA transmission have been associated with several functional syndromes, such as psychosis (2) and drug addiction ( 3 ).

Whereas DA is an essential neurotransmitter of the basal ganglia, it exerts modulatory actions on neuronal circuitries that utilize amino acids and/or neuropeptides as chemical messengers. In the striatum, DA terminals directly link with mediumsize spiny neurons utilizing ramino butyric acid (GABA) as a principal neurotransmitter, but also with neurons utllizing opioid or tachykinin peptides (4). In the striatum, acetylcholine (ACh) is found in intrinsic large size neurons (5). It has been suggested that striatall $A C h$ neurons are not synaptically linked with DA terminals (6). However, in an electron microscopy study, Kubota et al. (7) presented evidence that striatal cholinergic neurons may indeed receive direct inputs from dopaminergic axons. In agreement, we have recently shown, in an in situ hybridization study, that approx $95 \%$ of large size neurons in the striaturn express mRNA for DA D-2 receptors (8).

The medium-size spiny neurons project axons to the globus palliclus and to the substantia nigra. Neurons projecting to the globus pallidus contain both GABA and enkephalin, whereas striatc-nigral fibers contain GABA, substance P, and dynorphin (9). There are studies showing that in the striatum, DA exerts, via different receptors, selective actions on neuropeptides associated to different projection systems (10). Dopamine acts on striato-pallidal neurons via. D-2 type of receptors and on striato-nigral neurons via D1 receptors. Thus, DA receptor multiplicity provides a gating system funneling striatal activity via different efferent pathways, a hypothesis largely developed in our own laboratory (11-19).

The interaction between DA and the neuropeptide cholecystokinin (CCK) has been an important issue for describing the functioning of the basal ganglia. The issue has been discussed in rather oversimplified terms and without morphological background. In the striatum, several different CCK systems exist, with both intrinsic and extrinsic origin (20). A proportion of mesencephalic DA neurons projecting to the telencephalon utilizes $C C K$ as a cotransmitter (21), and this neuropeptide is also present in cortico-striatal projections, probably colocalized with glutamate. We have recently reported evidence for a partly crossed CCK corticostriatal pathway in the rat $(22-24)$. Little is, however, known about the functional interactions between CCK and DA and the contributions from each particular system to the final output of the basal ganglia.

Several methods have been applied to study interactions between monoamines and neuropeptides in the brain, the majority of them utilizing indirect neuroanatomical or behavioral techniques. We have chosen to utilize the novel technique, largely developed in our laboratory, of in vivo microdialysis (25), which allows the simultaneous monitoring of the release of monoamines, $\mathrm{ACh}$, amino acids, and peptides in restricted regions of the brain. Thus, the interactions among different nuclei of the basal ganglia have been studied with in vivo microdialysis, in normal and lesioned rats. $\mathrm{DA}, \mathrm{ACh}$, glutamate, aspartate, GABA, purines, lactate, and pyruvate are assayed with high-performance liquid chromatography (HPLC), coupled to electrochemical (EC), fluorescence (F), or ultraviolet (UV) detection systems. Neuropeptides are measured by sensitive radioimmunoassays (RIA.) utilizing selective antibodies. Rotational behavior $(11,12,26)$, simultaneously with microdialysis or in parallel experiments has a'so been recorded. Histochemistry and in situ hybridization studies have. also been performed.

The main aim of these studies is, however, to characterize pharmacological treatments. Drugs have been analyzed in experimental models mimicking Parkinson's or Alzheimer's diseases. Attention has been given to the effects of treatments with endogenous and exogenous trophic factors, such as nerve growth factor (NGF), the monosialoganglioside GM1, and nicotine.

\section{Functional Neuroanatomical Studles \\ Madulation of Striatal DA Release by Striato-Nigral Pathways}

Striatal D.A release is differently modulated by striato-nigiral GABA, dynorphin, substance $P$, and neurokinin A pathways. GABA and dynorphin exert a negative feedback on striatal DA, whereas substance $\mathrm{P}$ and neurokinin $\mathrm{A}$ provide a positive 
feedback $(27-29)$. The effects produced by substance $P$ and neurokinin $A$ are conveyed via different receptors $(30,31)$, and via different neuronal $(32,33)$ and metabolic $(34,35)$ pathways $(36)$. We have found that exogenously administered substance $\mathrm{P}$ may be cleaved to a shorter active fragment (substance $\mathrm{P}[1-7]$ ), which can then have antagonistic properties against substance $P(34)$, in contras! to the $\mathrm{C}$-terminal substance $\mathrm{P}$ fragment (substance $P$ [6-11]), which does not exert any significant modulation on the effects of substance $\mathbf{P}$ (35).

In order to monitor closely the neurotransmitter cascade connecting the substantia nigra and the striatum, the sensitivity of the analytical assays had to be in the lower pico- and femtomole levels for. monoamines and amino acids, and peptides, respectively. Thus, following implantation of microdialysis probes into the striatum and into the substantia nigra, we can now simultaneously monitor monoamines, amino acids, and neuropeptides in both regions. Figure 1 shows dynorphin $B$ and GABA levels simultaneously' monitored in left striatum and left substantia nigra under basal and $\mathrm{K}^{*}$-depolarizing conditions. The GABA antagonist biccuculine has been included together with the $\mathrm{KCl}$, in order to block the effect produced by a massive release of GABA.

The effects of striatal or intranigral administration of the dopamine D-1 agonist SKF 38393, and the D-2 agonist quinpirole on GABA and dynorphin release have been studied. We have found that $100 \mu \mathrm{M}$ of SKF 38393 included in the striatal perfusion medium produces a greater than twofold increase in rigral GABA. and dynorphin levels, whereas no such effect has been observed after quinpirole. In contrast, nigral quinpirole, but not SKF-38393, produces a concentrationdependent decrease in striatal dopamine levels. In the nigra, SKF-38393 induces an increase of nigral GABA and dynorphin levels (85).

\section{Modulation of Striatal DA Release by Cortico-Striatal Pathways}

There is evidence that striatal DA release is presynaptically modulated by glutamatergic cortical inputs. It was proposed that the DA stimulation produced by glutamate reflected direct axonal interactions between glutamatergic and dopaminergic terminals in the striatum. This hypothesis received some support from biochemical and histochemical studies showing direct intrastriatal axonal interactions. However, the majority of the striatal afferents from the cortex and substantia nigra make axodendritic synaptic contacts with striatal neurons (37), giving a basis for polysynaptic loops, including GA.BA and/or ACh neurons, by which cortical glutamate neurons can also modulate striatal DA release $(38,39)$.

We have found that cortical stimulation produces an increase in striatal ACh and DA release (39). These effects, however, seem to be mediated. by different glutamate receptors; kainate agonists produced an increase in striatal DA release, whereas NMDA agonists produced an increase in striatal A.Ch release $(38,40)$. The development of this model will enable us to follow the changes in extracellular striatal monoamine, amino acid, and neuropeptide levels during cortical stimulations. We have found, however, that the study of the interactions between corter and striatumn is complicated by the fact that inputs onto the striatum are partly originating in the contralateral side. Thus, we have reported that glutamate and CCK are released from a partly crossed cortico-striatal pathway $(41,22-24)$.

Evidence for the presence of DA nerve terminals in the deep layers of the frorito-parietal cortex. of the rat has been presented (42). In this cortical region, extracellular DA is found in a 1-nM range and can be increased by $\mathrm{K}^{+}$-depolarization or amphetarnine stimulation, and suppressed by mesencephalic $60 H D A$ lesions $(42,43)$. Nigral administration of substance $P$ producess an increase in both cortical and striatal DA release, whereas neurokinin $A$ stimulates striatal DA release only (43). Differences; in striatal and cortical DA functions have also been found in studies measuring the miRNA expression of several putative neurotransmitters with in situ hybridization and RNA blots. We have found that glutamic acid decarboxylase (GAD, a marker for GABA neurons), somatostatin, and NPY mRNA gene expression were increased in the striatum, but decreased in the cortex following DA deafferentation $(44,45)$, suggesting therefore that DA has different functional roles in the striatum and frontoparietal cortex.

Extracellular levels of ACh can be simultaneously measured in the cortex and striatum of rats (46). These levels could be selectively stimulated by several pharmacological treatments and inhibited by specific lesions. A unilateral ibotenic acid lesion into the nucleus basalis, but not into the striatum, produced a strong decrease in extracellular ACh levels in the ipsilateral cortex (47). Unilateral decortication with the excitotoxin kainic acid, which selectively damages local neurons while sparing 
nicotine administered by subcutaneously implanted Alzet minipumps counteracts the decrease in extracellular neostriatal DA induced by the transection, supporting the idea that chronic nicotine may protect against degeneration of central DA neurons $(58,59)$.

\section{Models for Dementia of Alzheimer Type}

We have proposed two models to study dementia of Alzheimer type, one based on cortical infarcts induced by devascularizing lesions $(46,60,61$; see also ref. 1) producing retrograde degeneration of neurons in the nucleus basalis, and another where lesions are directly performed into the nucleus basalis (47). The effects of NGF and GM1 treatments on neural repairing have been studied in these models. We have found that chronic administration of GM1 or NGF could reverse biochemical and morphological changes induced by these lesions $(46,60,61)$.

In vivo microdialysis has been used to study the effects of the aziridinium ion of ethylcholine inustard (AF64A), a powerful alkylating agent that binds to high-affinity choline uptake sites, on Intrasic and exirinsic neuronal systems of rat neostriatum. This neurotoxin has been proposed as a selective toxin for cholinergic neurons, and thus, perhaps, a useful tool in the development of animal models of Alzheimer's disease and senile dementia of the Alzheimer type (62). We compared the effect of AF64A to that of ibotenic acid on striatal ACh, GABA, DA, glutarnate, and aspartate levels (63). We concluded that, although AF64A is a potent neurotoxin for intrinsic neuronal systems, it appears, like ibotenic acid, to have similar effects on local cholinergic and GABAergic neuronal systems in the striatum.

\section{Pharmacological Treatments}

\section{Mechanisms of Actions of Antiparkinsonian Drugs}

Most of the antiparkinsonian drugs are DA agonists. Therefore, we have studied the selectivity of several DA agonists on different receptor populations and proposed the idea that receptor multiplicity may constitute a mechanism by which the actions of DA are gated by different neuronal pathways (15). Studies with rotational behavior (11-14), microdialysis (14-19,40,64), and recently, studies with in situ hybridization histochemistry combined with fluorogold tracing technique (10) support this hypothesis $(65,66)$. We have found that, in the striatum, DA exerts an inhibitory modulation on GABA neurons via D-2 receptors, whereas D-1 stimulation exerts a stimulatory modulation on GABA neurons (19).

Looking for new antiparkinsonian therapies, we have found that caffeine shares some of the properties of DA agonists. Thus, the methylxanthines, caffeine, theophylline, and theobromide produce rotational behavior in 60HDA lesioned rats, a behavior partially inhibited by DA antagonists $(67,68)$. Although we have studied several hypotheses, we still lack conclusive results to support a single mechanism for explaining the effects produced by methylxanthines in $60 \mathrm{HDA}$ lesioned rats (67-73).

\section{Treatment with Endogenous and Exogenous Trophic Factors}

The idea that degenerative processes may be delayed or even reversed by exogenously administered trophic factors, such as NGF and GM1, is now accepted. NGF is synthesized within target tissues of some peripheral and central neurons and can act on specific receptors (74). NGF, in turn, is internalized and retrogradely transported to cell bodies (75). Thus, NGF can be used as a pharmacological tool to induce nerve growth and repair.

At the beginning of the 1980 s, we studied the promotion of phenotypical transformation of chromaffin cell grafts by NGF. We were the first to report in vivo studies $(50,76,77)$ showing that NGF could induce changes in chromaffin cells grafted into a DA deafferented striatum, transforming their endocrine-like into a neuron-like feature. It was found that the changes were associated with the reversing of symptoms of experimentally induced parkinsonism. We also showed the effects of NGF treatments on extracellular $\mathrm{ACh}, \mathrm{DA}$, and adenosine levels in the cortex and striatum of rats with unilateral devascularizing cortical lesions (61).

Another neurotrophic factor, the monosialoganglioside GM1, has also been tested for the promotion of nerve growth and repair (78). GM1 can prevent retrograde changes in nucleus basalis produced by cortical lesions (79) and might also stimulate the activity of cortical cholineacetyltransferase in regions adjacent to the lesions. We have extended these studies by analyzing the effects of decortication and treatments with GM1 on cortical and striatal $\mathrm{ACh}$, catecholamines, and adernosine lev- 
els measured with microdialysis (46). A novel administration route for neurotrophic factors, i.e., microencapsulation into human serum albumin microspheres, which can then be topically applied onto damage regions, has also been studied (60). Such treatments with GM1 promote (1) recovery of retrograde morphological changes produced by devascularization and (2) a parallel increase in cortical $\mathrm{ACh}$ release. Although these results appear to be promising, the possibility that excessive trophic stimulation might lead to aberrant connections in addition to, or instead of functionally reparative ones has to be carefully investigated.

\section{Perinatal Asphyctic Lesions}

\section{The Experimental Model}

We have developed a noninvasive animal model for studying the short-and long-term consequences of hypoxic-ischemic lesions in rats, similar to those produced under labor in clinical situations (80). We found that perinatal asphyxia for a period longer than $22 \mathrm{~min}$, in a water bath at $37^{\circ} \mathrm{C}$, led to $100 \%$ mortality within the first 20-min period following ucuvcy. suweves, when ute uterus containung the pups was kept 22 min in a $30^{\circ} \mathrm{C}$ water bath, $100 \%$ of the pups recovered respiratory function following tactile oral stimulation and were accepted by the surrogate mothers (81, Loidl et al., in preparation). The protective effect of hypothermia at $30^{\circ} \mathrm{C}$ even allows for a $47-48-\mathrm{min}$ asphyctic period. When asphyxia was induced in a water bath at $15^{\circ} \mathrm{C}, 100 \%$ survival could be extended to $101 \mathrm{~min}$.

\section{Short-Term Effects of Perinatal Asphyxia}

Several parameters are acutely or chronically recorded by direct observation or by in vivo microdialysis. Following asphyxia, pups are subcutaneously implanted with 4-mm microdialysis probes in the dorsal region, while kept on a heating pad (Fig. 2). Thus, subcutaneous levels of amino acids (glutamate, aspartate), and metabolism products (lactate, pyruvate, and ascorbate) are monitored during the $40-60$ - and $60-80$-min periods after removal from the uterus in asphyctic and controls pups.

\section{Effects of Delivering by Hysterectomy}

Pups delivered from uterus horns removed by hysterectomy from rats at the final day of gestation started regular breathing (respiratory frequency $60 / \mathrm{min}$ ) almost immediately after the delivering was completed. These control pups showed a pinkcolored skin and intensive vocalization and motility. They were accepted by surrogate mothers after an 80 -min observation period. When the pups were accepted, they grew up in a similar manner to that of normally delivered rats (at least during a 1-mo period of observation). Subcutaneous glutamate levels were $=2 \mu \mathrm{M}$; aspartate $=0.4 \mu \mathrm{M}$; lactate $=1$ $\mathrm{mM}$; and pyruvate $-60 \mu \mathrm{M}$.

\section{Short Asphyctic Exposure}

Following a 5-6-min asphyctic period, induced in a water bath at 37 or $30^{\circ} \mathrm{C}$, all the pups started breathing shortly after delivery. Their behavior was similar to that observed in the control animals. Following 5-6 min of asphyxia at $37^{\circ} \mathrm{C}$, glutamate levels were $=10 \mu \mathrm{M}$; aspartate $=1.2 \mu \mathrm{M}$; lactate $=2 \mathrm{mM}$; and pyruvate $=60 \mu \mathrm{M}$. At $30^{\circ} \mathrm{C}$ glutamate levels were $=6 \mu \mathrm{M}$; aspartate $=2 \mu \mathrm{M}$; lactate $=1 \mathrm{mM}$; and pyruvate $=40 \mu \mathrm{M}$. Following 15-16 min asphyctic periods, induced in a water bath at 37 or $30^{\circ} \mathrm{C}$, all the pups survived, without differences in color of the skin and respiratory frequency, as compared to the control animals. A silgnt aecrease in spontaneous motility was observed, but all the pups were, however, accepted by the surrogate mothers. At $37^{\circ} \mathrm{C}$, glutamate levels were $=7 \mu \mathrm{M}$; aspartate $=1 \mu \mathrm{M}$; lactate $=2 \mathrm{mM}$; and pyruvate $=60 \mu \mathrm{M}$. At $30^{\circ} \mathrm{C}$ glutamate levels were $=3$ $\mu \mathrm{M}$; aspartate $=0.5 \mu \mathrm{M}$; lactate $=2 \mathrm{mM}$; and pyruvate $=60 \mu \mathrm{M}$.

\section{Intermediate Asphyctic Exposure}

Following a 19-20-min asphyctic period at $37^{\circ} \mathrm{C}$, the pups had to be intensively stimulated to start breathing. The surviving pups remained akinetic for a long period after delivery, showed a significant decrease in respiratory frequency $(\approx 20 / \mathrm{min})$, which was accompanied by gasping and showed a pink/pale skin coloration. Approx $30 \%$ of the pups died shortly after delivery. In contrast, all the pups survived following a 19-20min asphyctic period at $30^{\circ} \mathrm{C}$. Initial gasping, a slight decrease in respiratory frequency $(=40$ ) $\mathrm{min}$ ), and in motility could be observed. The color of the skin was similar to that in control pups. All the surviving pups were accepted by the surrogate mothers. At $37^{\circ} \mathrm{C}$, glutamate levels were $=5$ $\mu \mathrm{M}$; aspartate $=0.5 \mu \mathrm{M}$; lactate $=2 \mathrm{mM}$; and pyruvate $=60 \mu \mathrm{M}$. At $30^{\circ} \mathrm{C}$ glutamate levels were $=6$ $\mu M$; aspartate $=1 \mu M$; lactate $\approx 2 \mathrm{mM}$; and pyruvate $=40 \mu \mathrm{M}$. 

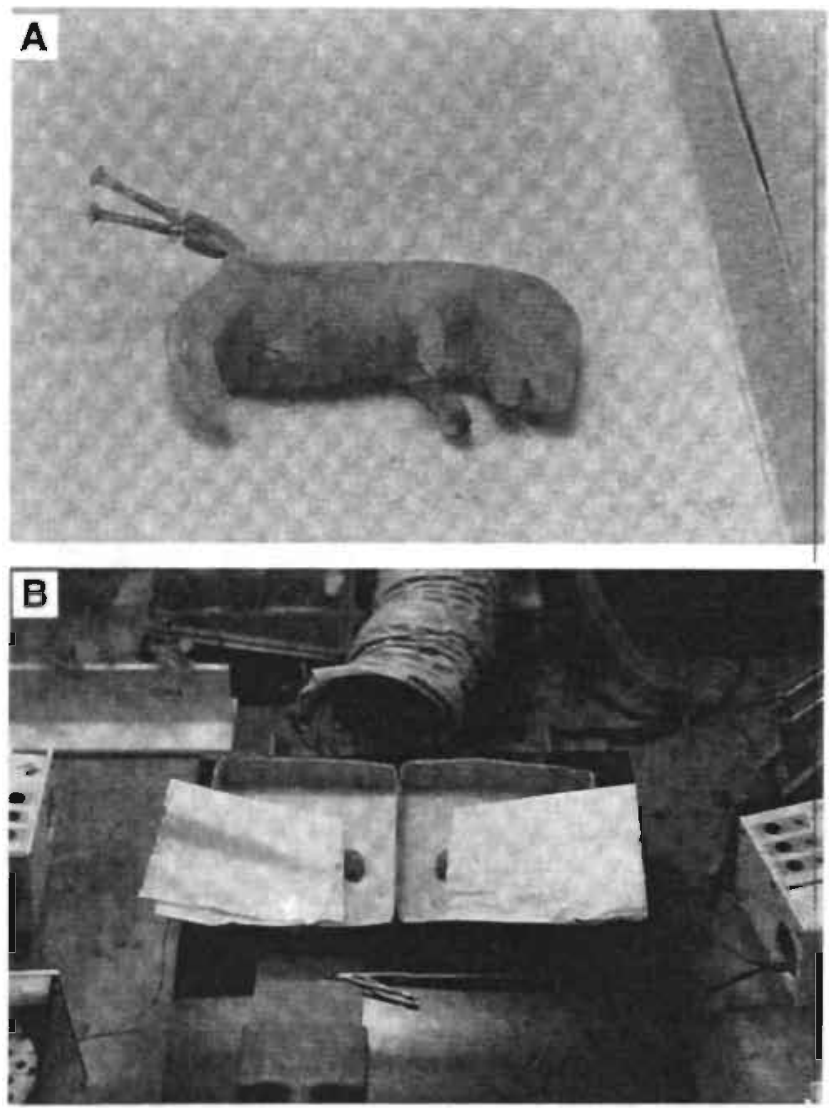

Fig. 2. (A) Pup recovering from a 19-20-min usphyctic period, at $37^{\circ} \mathrm{C}$. A 4-mm microdialysis probe was subcutaneously implanted into the clorsal region in order to monitor peripheral glutamate, aspartate, lactate, and pyruvate in $20-\min (40 \mu \mathrm{L})$ perfusion samples. Two fraction samples were taken before the pup was given to surrogate mothers. The experimental conditions under which the pups are normally microdialysed are shown in (B).

\section{Long Asphyctic Exposure}

The rate of survival rapidly decreased following prolenged asphyctic periods at $37^{\circ} \mathrm{C}$ ( $\left.>20 \mathrm{~min}\right)$, and as a whole, the physiological condition of the surviving pups deteriorated (increased gasping, decreased respiratory frequency, lack of vocalizaton, akinesia, and pale skin). No pups survived following asphyctic periods longer than $22 \mathrm{~min}$. In contrast, at $30^{\circ} \mathrm{C}$, all the pups survived up to a $30-$ 31-min asphyctic period, although sorne signs of physiological impairment (presence of gasping, decrease in respiratory frequency and motility, and pale skin) could be observed. At this temperature, $40 \%$ survival could be observed following a 47-48-min asphyctic period. All the surviving pups showed gasping, a decrease in respiratory frequency ( $=10 /$ min), akinesia, and pale skin. No survival was observed following asphyctic periods longer than 48 min. Following a 21-22-rnin asphyctic period at $37^{\circ} \mathrm{C}$, glutamate levels were $=4 \hat{\mu M}$; aspartate $=0.4 \mu \mathrm{M}$; lactate $=2 \mathrm{mM}$; and pyruvate $=90 \mu \mathrm{M}$. At $30^{\circ} \mathrm{C}$ glutamate levels were $=9 \mu \mathrm{M}$; aspartate $=1 \mu \mathrm{M}$; lactate $=2 \mathrm{mM}$; and pyruvate $-40 \mu \mathrm{M}$.

At $15^{\circ} \mathrm{C}, 100 \%$ survival was observed up to 101 $\mathrm{min}$ of asphyxia. Following a $50-51-\mathrm{min}$ asphyctic 


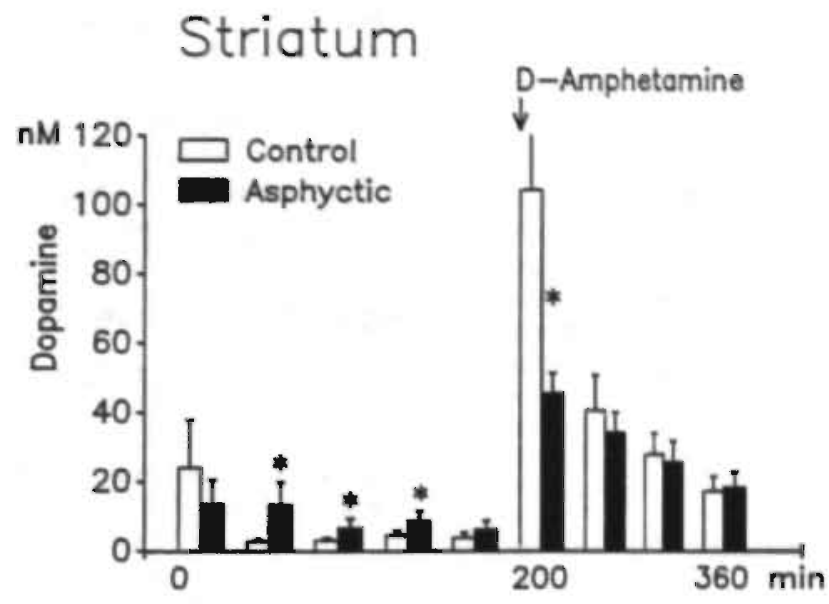

Fig. 3. Effect of perinatal 19-20-min asphyxia on extracellular striatal dopamine levels measured in samples collected by in vivo microdialysis 1 mo after delivery. A 4-mm microdialysis probe was implanted into the left striatum of halothane-anesthetized asphyctic $(n=7)$ and control $(n=6)$ rats. Microdialysis probes were perfused with a modified CSF solution. At the 200-min period following microdialysis implantation, a dose of $\mathrm{D}$ amphetamine ( $2 \mathrm{mg} / \mathrm{kg} \mathrm{sc}$ ) was administered. Dopamine was detected in $20 \mu \mathrm{L}$ samples using a highly sensitive HPLC-EC. Vertical lines show SEM. ${ }^{*}=p<0.05$ for the two-tailed test (Mann-Whitney U-test, corrected by the Bonferroni's procedure).

period, gasping was observed in $50 \%$ of the pups, the respiratory frequency was $=40 / \mathrm{min}$, vocalization and motility were decreased, and the skin was pink/pale. Following a 100-101-min asphyctic period at $15^{\circ} \mathrm{C}$, gasping was observed in all the pups, and the respiratory frequency was $10 / \mathrm{min}$. The pups were akinetic and pale, and no vocalization was observed.

\section{Long-Term Effects of Perinatal Asphyxla}

We have completed a series of experiments in which the pups were exposed to asphyxia and, approx 1-6 mo later, implanted with two microdialysis probes, one into the striatum and another one into the substantia nigra. Monoamines and amino acids were monitored under basal and Damphetamine-stimulated conditions.

Significant changes in monoamines and GABA were observed in rats exposed to subsevere and severe asphyxia, but nonsignificant effects were observed in glutamate and aspartate levels. Striatal extracellular DA levels were significantly increased in animals exposed to subsevere (19-20 min, at $37^{\circ} \mathrm{C}$ ) asphyxia (approximately twofold), although the effect of D-amphetamine on extracellular DA levels was significantly decreased ( $=50 \%$ compared to controls) (Fig. 3). Extracellular GABA levels in the substantia nigra were decreased by $=50 \%$. In animals with severe asphyxia $\left(>20 \mathrm{~min}\right.$, at $\left.37^{\circ} \mathrm{C}\right)$, a decrease in striatal DA levels was observed under basal $(m 70 \%)$ and under D-amphetarnine stimulation ( $\approx 50 \%$ compared to controls) (86). The increase in basal DA levels in subsevere asphyxia could be in agreement with a histochemical study (80) show" ing that under the same conditions, asphyxia produced an increase in the number of tyrosine hydroxylase-imununoreactive (TH-IR) nerve cell bodies, which was considered to be sign of proliferation of dopaninergic neurons. A cause for this increased number of nigral DA cell bodies was suggested to be a deficit in the GABAergic striato-nigral feedback, which would set the nigrostriatal DA neurons in a hyperactive state. In agreement with this is the present finding that there is a decrease in nigral GABA levels and a decrease in the effect of $D-$ amphetamine. Further studies combining microdialysis, immunohistochemistry, and quantitative histofluorometry are now in progress.

The present results show that perinatal asphyxia leads to death or to long-term neuronal deficits, affecting such systerns as the nigrostriatal dopamine pathway. The extent of the damage appears to 
depend directly on the length of the asphyctic period, as well as on the general metabolic condition under which asphyxia is induced. Thus, it is striking that decreasing the temperature from 37 to 30 or $15^{\circ} \mathrm{C}$ resulted in a significant increase in survival. This finding is in agreement with experimental studies demonstrating that low brain temperature protects brain neurons in rats subjected to transient forebrain ischemia $(82,83)$, an effect probably resulting from reduction in brain energy demands and a consequent decrease in the rate of ATP depletion (84).

\section{Summary}

The interactions among different nuclei of the basal ganglia have been studied with in vivo microdialysis, in normal and lesioned rats. DA, $A C h$, glutamate, aspartate, GABA, adenosine, and neuropeptides have been simultaneously monitored and assayed with highly sensitive HPLC and RLA methods. Rotational behavior has also been recorded, together or in parallel with microdialysis.

The modulation of striatal DA release by striatonigral and cortico-striatal pathways has been studied. It has been found that striato-nigral GABAergic and dynorphinergic pathways exert a negative feedback on striatal DA, whereas tachykininergic pathways exert a positive feedback on striatal DA. Cortical stimulation produces an increase in striatal DA release, probably via glutamatergic receptors of the kainate type. The interaction between cortex and striatum is, however, complicated by the fact that there are ipsilateral and contralateral cortical inputs, utilizing glutamate and CCK as transmitter signals.

Several experimental models have been developed to study the pathophysiology and therapy of neurodegenerative disorders of the basal ganglia. Different pathways of the basal ganglia are destroyed by intracerebral injections of selective toxins or surgical knife cuts. Thereafter, various drugs, including endogenous and exogenous trophic factors, are tested to reverse the effects induced by lesions.

A novel animal model to study the short- and long-term consequences of perinatal asphyctic lesions is presented. It has been found that perinatal asphyxia leads to death or to long-tern neuronal deficits. The extent of the damage appears to depend on the length of the asphyctic period, as well as on the general metabolic condition under which asphyxia is induced. Hypothermia appears to be a powerful treatment to increase survival following severe asphyxia. The presented model is largely noninvasive on the pups, and it mimics the condition produced under labor in clinical situations. Therefore, it appears to be useful as a model for studying treatments to ameliorate the deleterious effects induced by hypoxic-ischemic lesions.

\section{Acknowledgments}

This study was supported by a grant from the Swedish Medical Research Council (8669), Karolinska Institutet fonder, Loo och Hans Ostermans, Ake Wibergs, and Magnus Bervalls fonder. C. F. L. is a recipient of a CONICET, Argentina, fellowship. Z.-B. $Y$. is a recipient of a Guest Scientist Karolinska Institute, Stockholm, Sweden, fellowship. R. S. was supported by an IPICS, Uppsala, Sweden, fellowship.

\section{References}

1. Herrera-Marschitz M. and Ungerstedt U. (1990) Adz. Behav. Biol. 38, 453-458.

2. Carisson $\mathbf{M}$. and Carisson A. (1990) Trends Neurosci. $13,272-276$.

3. Koob G. F. (1992) Trends Phamacol. Sci. 13, 177-184.

4. Smith D. A. and Bolam J. P. (1990) Trends Neurosci. 13, $259-265$.

5. Bolam J. P., Wainer B. H., and Smith A. D. (1984) Neuroscience 12, 711-718.

6. Lehmarun L. and Langer S. Z (1983) Neuroscience 10, 1105-1120.

7. K.ubota Y., Inagaki S., Shinnada S., Kito S., Eckenstein F., and Tohyama M. (1987) Brain Res. 413, 1791-184.

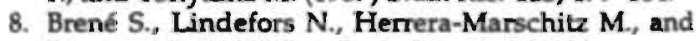
Persson H. (1990) Exp. Brain Res. 83, 96-104.

9. Graybiel A. (1990) Trends Nenurosci. 13, 244-254.

10. Gerfen C. R., Engber T. M., Mahan L. C., Susel Z, Chase T. H., Monsma F. J., and Sibley D. R. (1990) Science 250, 1429-1432.

11. Herrera-Marschitz M. and Ungerstedt U. (1984) Brain Res. 323, 269-278.

12. Herrera-Marschitz $M$ and Ungerstedt U. (1984) Eur. J. Pharmacol. 98, 165-176.

13. Herrera-Marschitz M., Stăhle L., Tossman U., Zetterströrn T., and Ungerstedt U. (1984) Acta Psych. Scand. 69 (311), 147-162.

14. Heirreral-Marschitz M and Ungerstedt U. (1987) Acta Physiol. Scand. 129, 371-380.

15. Herrera-Marschitz M. (1986) Neuropharmacology and. Functional Anatomy of the Basal Ganglia. ThesisKarolinska Institutet, Stockholm pp. 1-79.

16. Ungerstedt U., Herrera-Marschitz: M., Stlihle L., Tossman U., and Zetterström T. (1983) Acta Pharmac. Suecica 1, 165-181. 
17. Ungerstedt U., Herrera-Marschitz M., Stahle L., Tossman U., and Zetterstrôm T. (1985) Psychopharmacology Suppl. 2, 19-30.

18. Ungerstedt U., Herrera-Marschitz M, and Forster $C$. (1985) J. Clin. Psychintry 46, 34-37.

19. Reid M. S., O'Connor W. I., Herrera-Marschitz M. and Ungerstedt U. (1990) Brain Res. 519, 255-260.

20. Hokfelt T., Herrera-Marschitz M., Seroogy K., Ju G., Staines W. A., Holets V., Schalling M., Ungerstedt U., Post C., Rehfeld J. F., Frey P., Fischer J., Dockray G., Hamaoka T., Walsh J. H., and Goldstein M. (1988) J. Chem. Neuroanatomry 1, 11-52.

21. Hökfelt T., Skirboll L., Rehfeld J. F., Goldstein M. Markey K., and Dann O. (1980) Neuroscience 5, 2093-2124.

22. Herrera-Marschitz M., Meana J. J., Hokfelt T., You ZB., Morino P., Brodin E., and Ungerstedt U. (1992) NeuroReport 3, 905-908.

23. Morino P., Herrera-Marschitz M., Meana J. J., Ungerstedt U., and Hokfelt T. (1992) Neurosci. Lett. 148, 133-136.

24. You Z-B., Herrera-Marschitz M., Brodin E., Meana J. J., Morino P., Hōkfelt T., Silveira R, Goiny M., and Ungerstedt U. (1994) J. Neurochem. 62, 76-85.

25. Ungerstedt U., Herrera-Marschitz M., Jungnelius U., Stahle L., Tossman U., and Zetterstrom T. (1982) Adv. Biosciences 37, 219-231.

26. Ungerstedt U. and Arbuthnott G. (1970) Brain Res. 24, 485-493.

27. Herrera-Marschitz M., Christensson-Nylander I., Sharp T., Staines W., Reid M., Hökfelt T., Terenius L., and Ungerstedt U. (1986) Exp. Brain Res. 64, 193-207.

28. Herrera-Marschitz M., Nylander I., Reid M., Sharp T., Hökfelt T., Terenius L., and Ungerstedt U. (1987) in Substance $P$ and Neurokinins (Henry J., Couture R., Cuello C., Pelletier G., Quirion R., and Regoli D., eds.), Springer-Verlag, New York, Pp. 353-355.

29. Reid M., Herrera-Marschitz M., Hökfelt T., Terenius L., and Ungerstedt U. (1988) Eur. J. Pharmacol. 147, $411-420$.

30. Reid M. S., Herrera-Marschit M., Hokfelt T., Ohlin M., Valentino K. L., and Ungerstedt U. (1990) Neuroscience 36, 643-658.

31. Reid M. Hökfelt T., Herrera-Marschitz M, Hakanson R., Feng D. M., Folkers K., Goldstein M., and Ungerstedt U. (1990) Brain Res. 532, 175-181.

32. Reid M. S., Herrera-Marchitz M., and Ungerstedt U. (1990) Neuroscience 36, 659-667.

33. Reid M., Herrera-Marschilz M., Hokfelt T., Lindefors N., Persson H., and Ungerstedt U. (1990) Exp. Brain Res. 82, 293-303.

34. Herrera-Marschitz M., Terenius L., Reid M. S., and Ungerstedt U. (1990) Brain Res. 521, 316-320.

35. Reid M. S., Herrera-Marschitz M., Terenius L., Sakurada T. R, and Ungerstedt U. (1990) Brain Res. $526,228-234$.
36. Reid M. S. (1990) Neuropharmacological Circuitry of the Basal Ganglia Studied by in Vivo Microdialysis. ThesisKarolinska Institutet, Stockholm, pp. 1-69.

37. Somogyi P, Bolam J. P. and Smith A. D. (1981) J. Comp. Neurol. 195, 567-584.

38. Herrera-Marschitz M., Goiny M., Utsumi H., Ferre S., Guix T., and Ungertedt U. (1990) in Amino Acids (Lubec G. and Rosenthal G. A. eds.), Escom, Leiden, pp. 599-604.

39. Herrera-Marschitz M. (1991) in Basal Ganglia III (Bernardi G., Carpenter M. B., Di Chiara G., Morelli M., and Stanzione P., eds.), Plenum, New York, pp. 357-362.

40. Herrera-Marschitz M., Meana J. J. O'Connor W. T. Goiny M., Reid M. S., and Ungerstedt U. (1992) Amino Acids 2, 157-179.

41. Meana J. J., Herrera-Marschitz M., Brodin E., Hökfelt T., and Ungerstedt U. (1991) Amino Acids 1, 365-373.

42. Herrera-Marschitz M., Goiny M., Utsumi H. and Ungerstedt U. (1989) Neurosci. Lett. 97, 266-270.

43. Reid M. S., Herrera-Marschitz M., and Ungerstedt U. (1991) J. Newrochem. 57, 970-974.

44. Lindefors N., Brene 5., Herrera-Marschitz M., and Persson H. (1989) Exp. Brain Res. 77, 611-620.

45. Lindefors N., Brene S., Herrera-Marschitz M., and Persson H. (1990) Exp. Brain Res. 89, 489-500.

46. Maysinger D., Herrera-Marschitz M., Carlsson A. Garofalo L., Cuello A. C., and Ungerstedt U. (1988) Brain Res. 461, 355-360.

47. Herrera-Marschitz M., Goiny M., Utsumi H., Ferre S., Hakansson L., Nordberg A., and Ungeratedt U. (1990) Neurosci. Lett. 110, 172-179.

48. Johnston M. V., McKinney' M., and Coyle J. T. (1981) Exp. Brain Res. 43, 159-172.

49. Herrera-Marschitz M., Strömberg I., Olsson D., Ungerstedt U., and Olson L. (1984) Brain Res. 297, $53-61$.

50. Herrera-Marschitz. M., Strömberg I., Ebendal T., Ungerstedt U., and Olson L. (1984) Clinical Neuropharmacol. 7(Suppl. 1), 205.

51. Herrera-Marschitz M., Hyttel J., and Ungerstedt U. (1984) Acta Physiol. Scand. 122, 427-428.

52. Herrera-Marschitz M., Forster $C_{\text {, }}$ and Ûngerstedt U. (1985) Acta Physiol. Scand. 125, 529-535.

53. Herrera-Marschilz: M., Forster $C$, and Ungerstedt $U$. (1985) Acta Physiol. Scand. 125, 519-527.

54. Herrera-Marschite M. and Ungerstedt U. (1985) Eur. J. Pharmacol. 109, 349-354.

55. Zetterstróm T., Herrera-Marschitz $M$, and Ungerstecit U. (1986) Brain Res. 376, 1-7.

56. Herrera-Marschitz $M$. Utsumi $H$, and Ungerstedt $U$. (1990) J. Neurol. Neurosurg. Psych. 53, 39-43.

57. Agnat L. F., Fuxe K., Calza L., Zini I., Benfenati F., Farabegoli C., and Goldstein M. (1983) Acta Physiol. Scand. 119, 27-34.

58. Janson A. M., Meana J. J., Goiny M, and HerreraMarschíz M. (1991) Neurosci. Lett. 134, 88-92. 
59. Janson A. M. (1991) Protectioe Actions of Nicotine on Lesioned Nigrostriatal Dopamine Systems. ThesisKarolinska Institutet, Stockholm, pp. 1-42.

60. Maysinger D., Herrera-Marschitz M., Ungerstedt U., and Cuello A. C (1990) Neurosci. Lett. 118, 252-256.

61. Maysinger D., Herrera-Marschitz M., Goiny M., Ungerstedt U., and Cuello A. C. (1992) Brain Res. 577, 300-305.

62. Hanin I., Mantione C. R, and Fisher A. (1982) Aging 19, 267-270.

63. Meana J. J., Johansson B., Herrera-Marschitz M., O'Connor W. T., Goiny M., Parkinson F. E., Fredholm B. B., and Ungerstedt U. (1992) Broin Res. 596, 65-72.

64. Reid M. S., Herrera-Marschitz M., Kehr J., and Ungerstedt U. (1990) Acta Physiol. Scand. 140, 527-537.

65. Robertson H. A. (1992) Thends Neurosci. 15, 202-205.

66. Gerfen C. R. (1992) Ann. Reo. Neurosci. 15, 285-320.

67. Ungerstedt U., Herrera-Marschitz M., and Casas Brugue M. (1981) in Apomorphine, and Other Dopaminomimetics, vol. 1 (Gessa G. L. and Corsini G. U., eds.), Raven, New York, pp. 85-93.

68. Herrera-Marschite M. Casas M., and Ungerstedt U. (1988) Psychopharmacology 94, 38-45.

69. Fredholm B., Herrera-Marschitz M., Jonzon B., Lindströrn K., and Ungerstedt U. (1983) Pharmacol. Biochem. Behav 19, 535-541.

70. Ballarin M., Herrera-Marschitz M., Casas M., and Ungerstedt U. (1987) Neurosci. Lett. 83, 330-344.

71. Ferres S, Guix, I., Salles J., Badia A., Parra P., Jané F., Herrera-Marschitz M., Ungerstedt U., and Casas $M$. (1990) Eur. J. Pharmacol. 179, 295-299.

72. Ferré S., Herrera-Marschitz M., Grabowska-Anden M., Ungerstedt U., Casas M., and Anden N.-E. (1991) Eur. J. Pharmacol. 192, 25-30.

73. Ferré S., Herrera-Marschitz M., Grabowska-Anden M., Ungerstedt U. "Casas M., and Anden N.-E. (1991) Eur. J. Pharmacol. 192, 31-37.
74. Springer J. E. (1988) Expl. Neurol. 102, 354-365.

75. Shelton D. L. and Reichardt L. F. (1986) Proc. Natl. Acad. Sci. USA 83, 2714-2718.

76. Olson L., Backlund E.-O., Sedvall G., HerreraMarschitz M., Ungerstedt U., Strömberg I., Hoffer B., and Seiger A. (1984) in Catecholamines: Neuropharmacology and Central Neroous System-Therapeutic Aspects (Usdin E., Carlsson A., Dahlström A., and Engel J., eds.), Liss, New York, Pp. 198201.

77. Strömberg I., Herrera-Marschitz M., Ungerstedt U., Ebendal T., and Olson L. (1985) Exp. Brain Res. 60, 335-349.

78. Agnati L. F., Fuxe K., Calza L., Benfenati F., Cavicchioli L., Toffano G., and Goldstein M. (1983) Acte Physiol. Scand. 119, 347-363.

79. Cuello A. C., Stephens P. H., Tagari P. D., Sofroniew M. V., and Pearson R. C. A. (1986) Brain Res. 376, 373-377.

80. Bjelke B., Andersson K., Ören S.-O., and Bohlme P. (1991) Brain Res. 543, 1-9.

81. Herrera-Marschitz M., Loidl C. F., Andersson K, and Ungerstedt U. (1993) Amino Acids 5, 413-419.

82. Ginsberg M. D., Semau L. L., Globus M.-T., Dietrich W. D., and Busto R. (1992) Cerebrovasc. Brain Metab. Rev. 4, 189-225.

83. Coimbra C. and Wieloch T. (1992) Acta Physiol. Scand. 146, 543-544.

84. Young R. S. K., Oleginski T. P., Yagel S. K., and Towfighi J. (1983) Stroke 14, 929-934.

85. You Z.-B., Herrera-Marschitz M., Mylander I., Goiny M., O'Connor W. T., Ungerstedt U., and Teremius L. (1994) Neuroscience, in press.

86. Loidl C. F., Herrera-Marschitz M., Andersson K., You Z.-B., Goiny M., O'Connor W. T. Silveira R., Rawal R., Bjelke B., Chen Y., and Ungerstedt U. (1994) Nenirosci. Lett., in press. 


\title{
STRIATAL CYTOMEGALIC NEURONS CONTAINING NITRIC OXIDE ARE ASSOCIATED WITH EXPERIMENTAL PERINATAL ASPHYXIA: IMPLICATION OF COLD TREATMENT
}

\section{FABIAN LOIDL, FRANCISCO CAPANI, JUAN J. LOPEZ-COSTA, ESTER LOPEZ, ASIA SELVIN-TESTA. JORGE PECCI-SAAVEDRA}

Instituto de Biologia Celular y Neurociencias Eduardo De Robertis, LANAIS-MiE, Facultad de Medicina. Universidad de Buenos Aires,

\begin{abstract}
Summary Neuropathological mechanisms triggered by excitatory aminoacids are known to involve nitric oxide (NO). Neurons containing NO are histochemically reac. tive to nicotinamide adenine dinucleotide phosphate diaphorase (NADPH-d), which labels NO synthase in CNS. Sprague-Dawley male rats subjected to perinatal asphyxia (PA) at $37^{\circ} \mathrm{C}$, and PA plus $15^{\circ} \mathrm{C}$ hypothermia were evaluated when 6 months old by NADPH-d histochemical reaction. Computarized image analysis was used for quantification of stained sections. NADPH-d neurons in striatum from subsevere and severe PA showed a signifl. cant increment in soma size and dendritic process length versus control and hypothermic treated rats. Post-ischemic damage neurons are therefore involved in NO changes in. duced by PA that may be prevented by hypothermia treatment.
\end{abstract}

Key words: hypothermia, NADPH-diaforasa, perinatal asphyxia, striatum

Perinatal asphyxia (PA) remains a major complication in childbirth and its frequency is still high in spite of progress in health care. Affected newborns are prone to present neurological sequelae in the short- and long"term, their sever. ity depending on the length of oxygen deprivation. Thus, PA may lead to attentional deficit, hyperactivity, epilepsy, mental retardation, motor disorders, cerebral palsy or even death'. The basic cause of cerebral hypoxia in PA is pre- and intrapartum ischemia that produces a global brain neurotransmission alteration involving the nigrostriatal pathway " developing in adult rats as a long-term increase in basal striatal dopamine (DA) levels?

Hypothermia has been shown to prove critical for rat survival following PA induction. Indeed,

n.

Received: $10-1996$

Accepted: 21-11-1996

Postal adress: Dr. Jorge Pecel Saavedra, Instituto de Biologla Celular y Neurocienclas. Eduardo De Robertis, Facultad de Medicinu. Universidad de Buenos Aires, Paraguay 2155, 1121 Buenos Aires, Argentina.
$100 \%$ survival was achieved up to $15.16 \mathrm{~min}$ of asphyxia when PA was induced at body temperature $\left(37^{\circ} \mathrm{C}\right)$, but dropped to $20 \%$ after $20-21 \mathrm{~min}$, to fall to zero after $22 \mathrm{~min}$ of asphyxia. However, when P.A was induced at a lower temperature $\left(15^{\circ} \mathrm{C}\right)$, litter survival reached $100 \%$ even up to $100 \mathrm{~min}$ asphyxia².

So far, the pathological mechanism triggered after 16 min of PA leading to chronic neurotransmission alterations evidences in monoamines and $\mathrm{GABA} \hat{A}^{2.3}$ is poorly understood but may well involve the participation of excitatory aminoacids, nitric oxide and free radicals. Nicotinamide adenine dinucleotide phosphate diaphorase (NADPH-d) is commonly employed as a histochemical marker of NO synthesis in neurons ${ }^{4}$ and it was the fact that NO had been described to enhance DA release Irom striatums that encouraged us to evaluate NADPH-d distribution.

As striatum is severely affected by PA, we attempted to defineate the pattern of NADPH-d labelling in 6-month-old rat sections after various PA periods, either with or without hypothermia treatment. 
Sprague-Dawley rats on the last day of gestation were anaesthetised with ether and hysiterectomized, their gestational age being determined by palpation. The entire uterus containing the fetuses was taken out, the uterine homs were detached and placed in a water bath at $37^{\circ} \mathrm{C}$ for 5 or 10 min (both regarded as slight PA), 15 (moderate PA), 19 (subsevere PA) or over 20 (severe PA)2, or else in a bath at $15^{\circ} \mathrm{C}$ for 20 or $100 \mathrm{~min}$.

Cesarean-delivered control and asphyctic pups were obtained from the same mother. Following induction of asphyxia, the uterine horns were rapidly opened and pups rernoved and stimulated to breathe on a heating pacl by cleaning up the delivery fluid and by tactile stimulation with medical wipes. The umbilical cord was ligated and animals left to recover for around $1 \mathrm{~h}$ before given to surrogate mothers which had delivered normally $24 \mathrm{hs}$ before the experiment, mixing their normal litters with marked asphyctic and caesarean-delivered control pups.

On becoming adults at six months of age ( $\mathbb{N}=$ 4-5 animals/group), they were anaesthetized with sodium pentobarbital $\left(60 \mathrm{mg} \mathrm{kg}^{-1}\right)$ and pertused through the aortic artery with $0.9 \% \mathrm{NaCl}$ solution followed by $300 \mathrm{ml}$ of $4 \%$ paratormaldehyde in $0.1 \mathrm{M}$ phosphate buffer. Brains were removed and postfixed in the same solution during $2 \mathrm{hs}$, then immersed overnight in a solution containing $20 \%$ sucrose in $0.1 \mathrm{M}$ phosphate butfer. Sections 40 $\mu \mathrm{m}$ thick were cut on an Oxiord vibratome and mounted on gelatin-coated glass slides, then processed by the NADPH-d histochernical method. Briefly, sections were incubated for 1 th at $37^{\circ} \mathrm{C}$ in a solution containing $0.1 \%$ B-NADPH and $0.02 \%$ nitroblue tetrazolium diluted in $0.1 \mathrm{M}$ phospate buffer with $0.3 \%$ Triton $\mathrm{X}-100$ (all reagents purchased from Sigma, U.S.A.). Sections were mounted in PBS/glycerol (1: 3), then observed and photographed with a Zeiss Axiophot microscope.

Mean number and cell perimeter of NADPH. d+ cells per random field from 10 striatal sections belonging to each group were calculated using a KONTRON/NIDAS image analyzer, quantifying a total of 10 cells per section. Sections were observed with a 40k objective, and images digitized using an Axiophot Zeiss microscope linked to the computer by a SONY video camera. Differences between groups were compared using analysis of variance (ANOVA), taking $p<0.05$ as significant. Results are given as means \pm SD.

Without exception, NADPH- $\varangle$ staining in striatum transverse sections from 6-mont-old rats showed uniformly distributed medium-sized neurons. Subsevere and severe PA groups disclosed so-called neuronal cytomegalys, together with an evident increase in tortuous dendritic arborizations compared to control, remaining PA groups at $37^{\circ} \mathrm{C}$ and those subjected to 20 and 100 minutes PA at $15^{\circ} \mathrm{C}$.

In rats exposed to subsevere and severe PA, striatal cell perirneter disclosed highly significant cytomegaly $(p<0.001)$ versus control, slight and moderate $\mathrm{PA}$ at $37^{\circ} \mathrm{C}$ and $\mathrm{PA}$ at $15^{\circ} \mathrm{C}$ groups during 20 or 100 minutes (Fig. 1 and Table 1). Mean striatal cell count per field with a $40 \mathrm{X}$ objective was $5=1$, lacking significant intergroup difterences.

In agreement with reports describing NADPH-d+ striatal cells as interneurons containing somatos:tatine and neuropeptide $Y^{7}$, in adult rat such neurons were of medium size and non-spiny type. Due to their lack of NMDA receptors' and high concentration of manganese superoxide dismutase", these cells were regarded to be resistant to excitatory aminoacid toxicity and to free radicals toxicity respectively. Nevertheless, the broader implications of $\mathrm{NO}$ as a neurotoxic or neuroprotective modulator remain a subject of controversy.

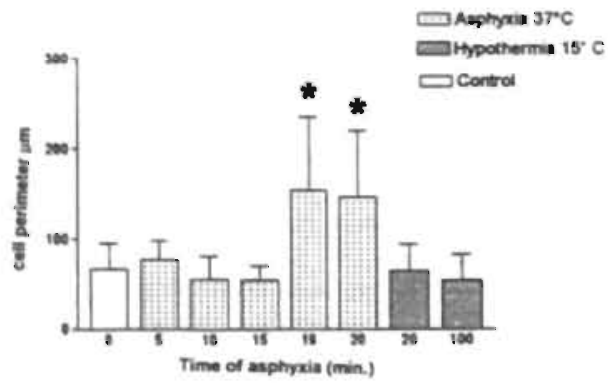

Fig. 1.- Measurement of striatal NADPH-d+ cell perimeter, in 6-month-old rats subjected to different periods. of PA at $37^{\circ} \mathrm{C}$ or $15^{\circ} \mathrm{C}$. Each value represents mean * SD (vertical lines) of determinations made from $n=$ 100 cells from each group. Asterisk indicates that NADPH-d+ in these two groups was significantly different $(p<0.001)$ from the remainder. Statistical analysis was performed by ANOVA test. There were no significant differences between subsevere and severe PA. 
TABLE 1. Cel perimeter or rat striatal neurons following various peniods of newbom asphyoda

\begin{tabular}{|c|c|}
\hline $\begin{array}{l}\text { Time of asphyxia } \\
\text { (minutes) }\end{array}$ & $\begin{array}{l}\text { Perimeter } \\
\text { (ym) } \\
\text { Mean SD }\end{array}$ \\
\hline
\end{tabular}

\begin{tabular}{ccc} 
Zero (control) $37^{\circ} \mathrm{C}$ & $67.10 \pm 28.11$ \\
$5-6$ & $37^{\circ} \mathrm{C}$ & $77.66 \pm 20.55$ \\
$10-11$ & $37^{\circ} \mathrm{C}$ & $55.30=16.82$ \\
$15-16$ & $37^{\circ} \mathrm{C}$ & $53.79 \pm 16.82$ \\
$19-20$ & $37^{\circ} \mathrm{C}$ & $153.28 \pm 81.12^{\circ}$ \\
$20-21$ & $37^{\circ} \mathrm{C}$ & $145.56 \pm 73.57^{\circ}$ \\
$20-21$ & $15^{\circ} \mathrm{C}$ & $84.47 \pm 29.64$ \\
$100-101$ & $15^{\circ} \mathrm{C}$ & $54.01 \pm 28.36$ \\
\hline
\end{tabular}

- Significantly different from the remaining groups ( $P<0.001)$ but not between them.

Several neurological disorders are liable to induce changes in NADPH.d stained neurons. To illustrate, in Huntington's disease there is an increase in striatal NADPH-d+ cell measurements concomitantly with cell and fiber sparing, perhaps due to loss of striatal spiny neurons?. A recent report on human Parkinson's and Alzheimer's diseases has documented a relative NADPH-d+ cell sparing in striatal neurons displaying shrunken and foreshortened dendritic processes ${ }^{\circ}$. In the present study, an experimental model was specially designed to evaluate PA effects in adult animals ${ }^{2}$. NADPH-d technique disclosed positive cells of the same type, homogeneously distributed in asphyctic and control rat striatum. However. strialal NADPH-d+ neurons from rats subjected to subsevere of severe PA proved highly cylomegalic compared with control and hypothermiatreated animals, indicating that the pathological mechanism involved in PA is dissirnilar to that in Alzheimer's, Parkinson's, and Huntington's diseases.

Alterations found in rat striatal NADPH-d+ neurons closely resembled those reported by Mischel et $\mathbf{a l}^{b}$ who documented cortical neuronal cytomegaly in pediatric epilepsy.

As NO induces DA release, which may be blocked by the NO synthase inhibitor L-Me-Args, the higher basal level of striatal DA after an episode of severe $P A^{2}$ seems to agree with the number of NO-containing hypertrophic striatal neurons.
Besides, NO plays a major role in regulating blood flow by inducing relaxation of the vascular smooth muscle $"$, and most likely protects against ischemia by enhancing oxygen supply. The ability to stimulate DA release, considered toxic in striatum after ischemia", together with its potent vasoconstrictor effect may worsen cell damage. However, since DA release is inhibited by hypothermia ${ }^{2}$, its protective mechanism is attributable to inhibition of the excessive release of striatal DA indirectly stimulated by NO.

In spite of the therapeutic application of hypothermia to reduce the severity of ischemic cerebral damage described in several studies in rats and gerbils ${ }^{2}$, data on PA is mostly limited to the 1950 s and $1960 \mathrm{~s}$, when cold therapy plus positive pressure ventilation was introduced to resus: citate severely asphyxiated human neonates, previously regarded as incapable or recovery, with and excellent outcome evidenced by a rapid increase in Apgar scores: 13,14 . Metabolic demands decrease when body temperature is lowered" so that toxic effects are weakened and survival to asphyxia ensured without permanent brain lesions.

However, the functional consequences arising from striatal NO-containing cytomegalic neurons after an episode of subsevere and severe PA are still obscure, so that further studies on cold therapy in the treatment of severely asphyctic babies are essential.

In conclusion, our findings demonstrate that NADPH-d reactivity is enhanced in striatal neuions containing NO secondary to chronic PA-inducecl ischemia due to a subsevere or severe lack of oxygen and that permanent brain damage may be prevented by hypothermia treatment.

\section{Resumen}

Neuronas estriafales citomegálicas que expresan oxido nitrico se asocian con asfixia perinatal experimentat: implicancias del' tratamiento con frio

El óxido nitrico (NO) se encuentra directa o indirectamente relacionado con mecanismos neuropatológicos iniciados con la liberación de aminoácidos excitatorios. Se pueden detectar histoquímicamente las neuronas $\mathrm{NO}+$ por su reacción a la nicotinamida adenina dinuclétido 
fosfato diaforasa (NADPH-d), colactor específico para la enzima NO sintetasa en el SNC. Se estudiaron con NADPH-d secciones de núcleo estriado de ratas Sprague-Dawley de 6 meses de edad que fueron expuestas a un modelo de asfixia perinatal (PA) durante varios periodos de tiempo tanto a $37^{\circ} \mathrm{C}$ como a $15^{\circ} \mathrm{C}$ (tratamiento hipotérmico). Para cornparar el patión de tinción de los diferentes grupos experimentales se realizo un estudio de análisis de imágenes cuantitativo. Las neuronas estriatales NADPH-d+ de ratas de 6 meses que fueron expuestas a PA subsevera y severa mostraron un aumento significativo en sus prolongaciones dendríticas y del tamaño del soma en relación a los controles, a los animales tratados con hipotermia y a los restantes grupos de PA a $37^{\circ} \mathrm{C}$. Estos datos indican que existen cambios crónicos en las neuronas que expresan NO del estriado post-isquémico y que estas alteraciones inducidas por PA pueden ser prevenidas con el tratamiento hipotérmico.

\section{Acnowledgements}

We would like to express our gratitude for the excelIent technical assistance of Mrs Emérita Jorge Vilela de Banchieri. This work was supported by grants from the University of Buenos Aires and CONICET (Consejo Nacional de Investigaciones Cientificas y Técnicas).

\section{References}

1. Volpe J. Neurology of the newborn. Philadelphia: WB Saunders, 1987.

2. Herrera-Marschitz $M$, Loidl CF, You ZB, et at. Neurocircuity of the basal ganglia studied by moniforing neurotransmitter release. Molec Neurobiol 1994; $9: 171.82$.
3. Loidl CF, Herrera-Marschitt! M', Andersson $K$ ot al Longl-term exfects of perinatal asphyxia on basal ganglia: neurotransmitter systenns studied with microdialysis in rat. Nourosci Let7 1994; $175: 9-12$.

4. Hope B. Michael G, Knigge K et al. Neuronal NADPH-diaphorase is a nitric oxide synthetase. Proc Nat' Acad Sci USA 1991: 88: 28:1 1-4.

5. Znu X, Luo L. Effect of nitropusside (nitric oxide) on endogenousi dopamine release from rat striatali slices. J Neurocheml 1992; 59: 932-5.

6. Mischell P, Nguyen Landi Vinters H. Cerebral corki. cal dysplasia associated with pediatric epilepsy. Review of neuropathologic features and proposal for a grading system. J Neiropathol Exp Nourol 1995; 54: 137-53

7. Ferrante $\mathrm{A}$, Kowall. $N$, Eeal $\mathbf{M}$ e? al Selective sparing of a class of striatal neurons in Huntingiton's disease: Science 1985; 230: 5/51-3.

8. Inagaki S, Suzuki K, Taniguchi $\mathrm{N}$ et al. Localization ot Mn-superoxide dismutase (Mn-SOD) in cholinergic and somatostatin-containing neurons in the rat neostriatum, Brain Res 1998: 549: 174.7.

9. Mutson E. Brandabur M. Sparing of NADPH. diaphorase striatal neurons in Perkinson's and Alzheimer's diseases. NeuroReport 1994; 5: 705-8.

10. Palmer Fl, Ferige A, Noncada S. Nitric oxider release accounts for the biological activity of endothellum . derived relusing bctor. Nature 1987; 327: 52:4-6.

11. Globus $M_{n}$ Ginsberg $M$, Dietrich $W$ et al. Substantia sigra lesion protects against ischemic damage in the striatum. Neurosci Lett 1987; 80: 251-6.

12. Glabus. $M$, Busto $R$, Dietrich $W$ e? al. Effect of ischemia orr the in vivo release of striatal dopamine. glutamate and GABA studied by intracerebral microdialysis. J Neurochem 1988; 1455-64.

13. Dunn JM, Miller JA Jr. Hypothermia combined with positive pressure ventilation in resuscitation of the asphyxiated neonate. Amer J Obstet Gynec 1969: 104: $58-67$

14. Westin $B$. Intant resuscitation and prevention of menhil retardation. Am J Obstet Gynecol 1971; 110; $1134-8$.

15. Miller JA Jr. New approaches to preventing brain damage during asphyxia. Am J Obstet Gynecol 1971; 110: $1125-33$

We cannot count on the medical solutions of the past to solve the problems of the future. Indeed, the re-emergence of old problems in new garments is programmed in the genetic machinery of evolution.

No podemos contar con las soluciones médicas del pașadọ para los problemas del futuro. De hecho, la re-emergencia de viejos problemas en nuevas vestiduras está programada en la maquinaria genética de la evolución.

\section{Richard Krause}

In: $A$ dancing matrix. How science confronts emerging viruses. Robin Marantz Henig. New York: Vintage Books, 1994, p 35 
The Int. J. of Neurosci. (In press)

LONG - TERM MORPHOLOGICAL CHANGES IN NADPH-DLAPHORASE

REACTIVITY IN STRLATAL AND CORTICAL NEURONS FOLLOWING

EXPERIMENTAL PERINATAL ASPHYXIA: NEUROPROTECTIVE EFFECTS OF HYPOTHERMLA

C. Fabián Loidl, Francisco Capani, Juan J. López-Costa, Asia Selvín-Testa,

Ester M. López and Jorge Pecci-Saavedra*

Instituto de Biologia Celular y Neurociencias "Prof. Eduardo De Robertis" and

LANAIS-MIE, Facultad de Medicina, Universidad de Buenos Aires, Paraguay $21553^{\circ} \mathrm{P}$, (1121) Buenos Aires, Argentina.

* Corresponding Author:

Prof. Dr. Jorge Pecci Saavedra

Instituto de Biologia Celular y Neurociencias "Prof. Eduardo De Robertis" and LANAIS-MIE, Facultad de Medicina, Universidad de Buenos Aires, Paraguay $21553^{\circ} \mathrm{P},(1121)$ Buenos Aires, Argentina.

FAX: 54-1-785-2164

PHONE: 54-1-961-5010. ExL 17,26

Email: ritalâfmuba.sld.ar 
SUMMARY: Nitric oxide (NO) is known to be directly or indirectly involved in neuropathological mechanisms triggered by excitatory aminoacids. $N O(+)$ neurons in brain may be detected histochemically by nicotinamide adenine dinucleotide phosphate diaphorase (NADPH-d) histochemical technique, as the latter readily labels NO synthase in central nervous system (CNS). NADPH-d stained striatal and cortical sections were studied in 6-month-old male Sprague-Dawley rats exposed to perinatal asphyxia (PA) at $37^{\circ} \mathrm{C}$, as well as in animals subjected to PA plus hypothermia treatment at $15^{\circ} \mathrm{C}$. Quantitative image analysis was performed to compare the staining pattern in the various groups. NADPH- $d(+)$ neurons in striatum and cortex from subsevere and severe PA animals showed a significant increase in soma size and in dendritic processes versus controls and hypothermia-treated rats. These findings indicate that chronic NO changes are involived in post-ischiemic stratal and 'cortical' alterations induced 'by PA' thiat may be prevented by hypothermia treatment

RUNNING TITLE: NADPH Diaphorase changes in perinatal asphyxia.

KEY WORDS Perinatal asphyxia - Hypothermia - NADPH Diaphorase $=$ Striatum Cortex - Rats 


\section{INTRODUCTION}

Perinatal asphyxia (PA) is still a major complication in childbirth and its frequency has not been reduced despite advances in health care. Affected newborn are liable to present short- and long-term neurological sequelae whose severity depends on the period of oxygen deprivation. Thus, PA may lead to hyperactivity, attentional deficit, epilepsy, mental retardation, motor disorders, cerebral palsy or even death.(Volpe, 1987). Some regions of the brain are particularly affected than others being the most sensitive and selectively vulnerable neurones located in the CA1, CA3 and CA4 regions of the hippocampus, cerebellum, neocortex in layers 3, 5 and 6 and neostriatum.(Percy 1986). Althoug the mechanism responsible for this vulnerability are not clear (Zhu \& Luo, 1992), a long-term increase in basal striatal dopamine (DA) levels has been demonstrated in the nigrostriatal pathway using microdialysis (Herrera-Marschitz, et al., 1994).

Fortunately, after ischemia, cell death does not occurs immediately and delayed for hours to days. This process, called delayed neuronal death (Paschen, 1991, Kirino, 1982), provides an opportunistic time window to reduce cell loss and associated learning and memory deficits. (Colboume, F. \& Corbett D., 1994).

At present the most effective treatment is intraischemic hypothermia, which has been repeatedly shown to confer remarkable histological and behavioral protection (Green, E.J. et. Al., 1992, Vicent, S., \& Kimura, 1992). Post-ischemic hypothermia has also been found to be beneficial when initiated within $30 \mathrm{~min}$.., of reperfusion (Busto, $\mathrm{R}$, et.al. 1987). It has already been demonstrated that hypothermia is critical for increases animal survival following PA induction. When PA was induced at body temperature 
$\left(37^{\circ} \mathrm{C}\right), 100 \%$ survival was achieved up to $15-16 \mathrm{~min}$ of asphyxia, whereas for 19-20 and 20-21 min periods, survival reached $70 \%$ and $20 \%$ respectively, with no survival after $22 \mathrm{~min}$ of asphyxia. In contrast, when PA was induced at lower temperature $\left(15^{\circ} \mathrm{C}\right)$, litter survival reached $100 \%$ even up to 100 minutes of asphyxia (Herrera-Marschitz, 1994; Loidl, 1993).

The pathological mechanism triggered after $16 \mathrm{~min}$ of PA leading to chronic neurotransmission alterations evidenced in monoamines and GABA (Herrera-Marschitz, 1994; Loidl, 1993) is still poorly understood but may involve the participation of the sequence: excitatory aminoacids, nitric oxide and free radicals. As regards nitric oxide (NO), nicotinamide adenine dinucleotide phosphate diaphorase (NADPH-d) is employed as a histochemical marker of NO synthesis in neurons (Hope, 1991; Uemura, 1990). Indeed, NO has been reported to stimulate DA release from striatum (Hanbauer, 1990; Zhu, 1992).

Since both striatum and brain cortex are severely affected by PA (Pasternak, 1991) the aim of this work was to analyse the pattern of NADPH-d labeling in 6-month-old rat sections following a range of PA periods with or without hypothermia treatment. 


\section{MATERIALS AND METHODS}

\section{Subjects}

Forty-two pregnants rats and fifty post-ischemic female rats, were included in this study. The dams were bred by housing three of them with one male until they were sperm positive as determined by vaginal smear. Pregnant rats were kept in individual stainless-steel cages and fed with Purine chow and tap water ad libitum. The $21^{\text {" }}$ day following the original mating, individuals females were placed in separate cages: Pregnancy was indicated by marked increase in weight, 25 to 30 grams, and by an enlargement of the abdomen which was evident at about the $13^{\text {th }}$ day of gestation Asphyxia was induced in pups delivered by caesarean operation.

\section{Induction of asphyxia}

Rats on the last day of gestation were anaesthetised with ether and hysterectomized. Gestational age was determined by vaginal smear. The entire uterus containing the foetuses, was taken out, the uterine horns were detached in a water bath at $37^{\circ} \mathrm{C}$ during the following periods : $5 \mathrm{~min} ., 10 \mathrm{~min}$,, (both considered slight PA), 15 moderate PA), $19 \mathrm{~min}$, (subsevere PA) and over $20 \mathrm{~min}$. (severe PA)

Asphyxia was induced in pups delivered by caesarean operation on pregnant Sprague-Dawley rats. Rats on the last day of gestation were anaesthetised with ether and hysterectomized. Gestational age was determined by palpation. The entire ute rus, containing the foetuses, was taken out, the uterine horns were detached and placed in a water bath at $37^{\circ} \mathrm{C}$ during the following periods in min: 5,10 (both considered slight 
PA), 15 (moderate PA), 19 (subsevere PA) and over 20 (severe PA) or at $15^{\circ} \mathrm{C}$ during 20 and $100 \mathrm{~min}$. (Herrera-Marschitz M, et. al., 1994).

Caesarean-delivered control and asphyctic pups were obtained from the same mother. Following asphyxia, the uterine horns were rapidly opened and pups removed and stimulated to breathe on a heating pad by cleaning the delivery fluid and by tactile stimulation with pieces of medical wipes. The umbilical cord was ligated and animals left to recover for around $1 \mathrm{~h}$ before given to surrogate mothers which delivered normally 24 hs. before the experiment, mixing their normal litters with previously marked asphyctic and control pups delivered by caesarea. Experimental and control pups were weaned at 24 days, and were transferred to stainless-steel cages, with free access to food and water, in compliance with the principles of animals care and Use of Laboratory Animals.

Once the animals became adults at an age of six months ( $\mathrm{N}=4-5$ animals/group), they were anaesthetised with $28 \%$ (w/v) chloral hydrate, $0.1 \mathrm{ml} / 100 \mathrm{~g}$ of body weight, and perfused with mixture of aldehydes through the abdominal aorta (Gonzalez-Aguilar, F. \& De Robertis E., 1963)

\section{Hislochemistry}

Rats were: perfused $4 \%$ paraformaldehyde in $0.1 \mathrm{M}$ phosphate buffer, $\mathrm{pH} 74$. Brains were removed and postfixed in the same solution during $2 \mathrm{~h}$., and then immersed overnight in solution containing $5 \%$ sucrose in $0.1 \mathrm{M}$ phosphate buffer $\mathrm{pH} 7.4$. Coronal sections from the brain containing the striatum $(40 \mu \mathrm{m}$ thick) were cut on an Oxford vibratome and mounted on gelatine-coated glass slides. Sections from treated (PA, PA + hypothermia) and control animals were simultaneously processed using the same react mixture NADPH-d histochemical method. (Vicent, S., \& Kimura, H., 1992). 
Briefly, sections were incubated for $1 \mathrm{~h}$. at $37^{\circ} \mathrm{C}$ in a solution containing $0.1 \% \beta-\mathrm{NADPH}$ and $0.02 \%$ nitrobluetetrazolium diluted in $0.1 \mathrm{M}$ phosphate buffer with $0.3 \%$ Triton $\mathrm{X}$ 100 ( all reagents were purchased from Sigma, St. Louis, MO, USA). Sections were mounted in PBS/ glycerol (1:3), and observed and photographed with a Zeus Axiophot microscope. In absence of NADPH, cells were not stained, substituting NADH for NADPH resulted in nonspecif staining of the entire section. Nitroblue tetrazolium contains a monoformazan impurity that gives a diffuse purple background (Valtschanoff, J G, et. al. 1993), to remove this some sections were incubated in acetone dimethyl sulfoxide for 10 minutes before mounting.

\section{Histology}

Rats were sacrificed either 10 or 45 days, after hypoxia with $28 \%$ (w/v) chloral hydrate $0.1 \mathrm{~mL} / 100 \mathrm{~g}$. Of body weight. Adjacent coronal sections ( $40 \mu \mathrm{m}$ thick) were collected and stained with Cresyl violet. Bilateral counts of neurones (well defined nucleus, distinct cellular membrane and not shrunken) were performed by an observer blind to treatment conditions. Neurones were counted in the lateral, medial, dorsal and ventral striatum at bregma -0.40 -interaural 8.6 and neurons in the medial and lateral sectors of neocortex at bregma -0.40 - interaural 8.6 (Paxinos and Watson, 1986). 


\section{Computerised Image Analvsis}

The NADPHd and cresyl violet stained neurons in sections of brains of different groups, were measured by using a computerised image analyser (Kontron-ZEISS VTDAS). The selected fields were located in the lateral, medial, dorsal and ventral of striatum and medial and lateral sectors of neocortex. Sections of $40 \mu \mathrm{m}$ thick with adequate labelling of NADPH diaphorase were randomly selected from coded slides ( 6 for each time of considered groups). Data from 50 selected striatum and surrounding neocortex were averaged for each animal. Ten cells per sections were analysed with a total of 100 for each group. Images from striatum and neocortex were obtained with a the light microscope and were transferred to a video camera attached and connected to an interactive analysis system on line (KONTRON- ZEUS VDDAS). The images were digitised into an array of $512 \times 512$ pixels corresponding to $140 \times 140 \mu \mathrm{m}(40 \times$ primary magnification). The resolution of each pixel was 256 grey levels ( 8 grey bits level resolution ). After automatic normalization of grey-scale, interactive delineation and contrast enhancement of the neuronal images were performed, following the removal of interfering non specify images. The projected surface of cresol violet and NADPH neurons were measured using morphometric parameters: area, perimeter, maximum and minimum diameter, shape factor in sections of experimental and control groups. The means and SD were calculated intreated and control groups.

The spatial distributions of NADPH and cresol violet staining neurones were counted using VIDEOPLAN image analysis system. They were digitised into 256 grey levels in measuring fields, $215 \times 180 \mu \mathrm{m}$ in size ( $20 \times$ primary magnification). NADPH 
positive cells count in per measuring field were performed. The mean and SD were calculated for the different fields studied in asphyctic and control groups.

\section{StatisticaLAnalysis}

Differences between means and SAD. of the experimental and control groups were analysed statistically using one- way analysis of variance (ANOVA) and subsequently the Newman-Keuls test, with a p value of less than 0.05 being considered significant. ANOVA and Newman-Keuls test were routinely performed on an IBM compatible PC AT 486 package software (Primer, Mc Graw Hill, Inc.). 


\section{RESULTS}

\section{Cresol violet staining in striatum}

Nineteen and twenty minutes of normothermic ischernia resulted in loss of neurones in medial, posterior, ventral and dorsal sector of the striatum (P 0.001). Hypothermia ( 20 minutes and 100 minutes at $15^{\circ} \mathrm{C}$ ), reduced neuronal loss ( P: 0.001). In the others groups ( 5,10 and 15 minutes) there were not differences with the control ( Table 1)

\section{NADPHd staining in the striatum}

NADPH-d staining in striatum transverse sections from 6-month-old rats showed uniformly distributed medium -sized neurones. Subsevere and severe PA groups disciosed an increase of the soma size accompanied by an enlargement of processes which showed an evident tortuous dendritic arborizations, distinctive of the so-called neuronal cytomegaly (Mischel, 1995), compared to controls and remaining PA groups at $37^{\circ} \mathrm{C}$, as well as 20 and $100 \mathrm{~min} . \mathrm{PA}$ at $15^{\circ} \mathrm{C}$ (compare Figs. $1 \mathrm{a}$, $1 \mathrm{~b}$ and $1 \mathrm{c}$ ). Labelled cell area and cell perimeter were measured by image analyșis in each experimental group. Both striatal cell area and cell perimeter of rats exposed to subsevere and severe PA showed a. highly significant cytomegaly $(p<0.001)$ in comparison to control, slight , moderate PA and PA at $15{ }^{\circ} \mathrm{C}$ group (Loidl F. 1995, 1996), during $20 \mathrm{~min}$. and 100 min. (see Fig. 3a and 3b).

Shape factor measurement of neurones failed to disclose statistical differences between striatal neurons in any studied group ( see figs. $3 \mathrm{c}$ and $4 \mathrm{c}$ ) 
There were not significant intergroup differences $(P=0.0001)$ in numbers of cells ( Table 1)

\section{Cresol violet staining in the neocortex}

Nineteen and twenty minutes of ischemia also resulted in severe loss of neurons in medial and lateral neocortex with statistically difference ( $P=0.0001$ ). Hypothermia ( $15^{\circ} \mathrm{C}, 20 \mathrm{~min}$. , and $100 \mathrm{~min}$. ) greatly attenuated neuronal loss ( $\mathrm{P} 0.0001$ ) (Table 2)

\section{NADPHd staining in the neocortex}

Likewise, in rats subjeted to subsevere and severe PA, medium sized NADPH-d+ in cerebral cortex, displayed morphological changes with the same characteristics of cytomegalic cells observed in striatum. Meanwhile, animals undergoing 20 and 100 min of PA at $15^{\circ} \mathrm{C}$ ( Loidl et al 1995 ) showed a staining pattern similar to controls and slight and moderate PA groups (compare Figs. $2 \mathrm{a}, 2 \mathrm{~b}$ and $2 \mathrm{c}$ ).

Cortical cell area and perimeter increased significantly in ratas exposed to subservere and severe PA $(\mathrm{p}<0.001)$ compared with control, slight, moderate PA and $\mathrm{PA}$ at $15^{\circ}$ treated animals during $20 \mathrm{~min}$.. and $100 \mathrm{~min}$., (see Figs. $4 \mathrm{a}$ and $4 \mathrm{~b}$ ).

There were no significant intergroup differences $(P=0.0001)$ in the number of cells (Table 4) 


\section{DISCUSSION}

In agreement with authors who described $\mathrm{NADPH}-\mathrm{d}(+)$ striatal and cortical cells as interneurons containing somatostatine and neuropeptide $\mathrm{Y}$, such neurons in adult rat proved to be of medium size and non-spiny in type (Ferrante R. et.al., 1985, Vicent S., \& Hope., 1992). Given their lack of NMDA receptors, (Vicent S., and Kimura H., 1992) as well as their high concentration of manganese superoxide dismutase, (Inagaki et. Al. 1991) these cells were regarded to be resistant to excitatory aminoacid toxicity and to free radical toxicity, respectively. However, the wider implications of NO as a neurotoxic or neuroprotective modulator are still a subject of controversy. (Schuman, E.\& Madison D., 1994)

Certain neurological disorders have been reported to induce changes in NADPHd stained neurons Thus, studies in patients with Huntington's disease have disclosed an increase in striatal NADPH-d(+) cell measurements associated with cell and fibre sparing, attributable to loss of striatal spiny neurons. (Vicent S. \& Hope B., 1992). Quite recently, a report on human Parkinson's and Alzheimer's diseases has documented a relative NADPH-d(+) cell sparing in striatal neurons with shrunken and foreshortened dendritic processes( Mufson E, \& Branabur M., 1994). In the present study, an expressly developed experimental model was employed to evaluate the effects of PA in adult animals.(Clifton, et.al., 1989, Ferrante, R., et.al., 1985, Bjelke, B., et al, 1991). NADPH-d technique disclosed positive cells of the same type, homogeneously distributed in rat striatum and cortex in asphyctic and control animals as shown by shape factor analysis. However, striatal and cortical NADPH-d $(+)$ neurons from rats subjected 
to subsevere or severe PA proved highly cytomegalic compared with control and hypothermia-treated animals, suggesting that the pathological mechanism involved in PA is different from that in Alzheimer's, Parkinson's, and Huntington's diseases.

Cortical neuronal cytomegaly has been documented in pediatric epilepsy.(Mischel, 1995). These findings are in agreement with similar alterations in rat striatal(Loidl, 1995, 1996) and cortical NADPH-d(+) neurons of the 6 month-old rats exposed to subsevere or severe PA.

Since NO induces DA release, which may be blocked the NO synthase inhibitor L-Me-Arg, (Zhu, X. \& Luo, L., 1992) the highest basal level of striatal DA chronically maintained following an episode of severe PA (Herrera-Marchitz, M. et.al.,1994) seems to correlate closely with the number of NO-containing cytomegalic striatal neurons.

Among other functions, NO plays a relevant role in regulating blood flow by inducing relaxation of the vascular smooth muscle,(Palmer, R. et. al,1987) perhaps. providing protection against ischemia by increasing oxygen supply. As NO stimulates DA release, which was reportedly to be toxic in striatum following ischemia, its potent vasoconstrictor effect may well worsen cell damage. However, as DA release is inhibited by hypothermia,(Globus, M., et al., 1987, Globus, M. et.al., 1988) its protective. mechanism may be explained by inhibition of the excessive release of striatal DA.

Despite the importance of hypothermia to reduce the severity of ischemic cerebral damage described in rats (Busto, R. et al, 1987), and gerbils,(Busto, R et al, 1989) only a few studies were performed in PA, except during the fifties and sixties, when cold therapy plus positive pressure ventilation was introduced in order to resuscitate severely asphyctic human neonates, previously considered incapable of recovery. Results were excellent showing a rapid increase. in Apgar scores.(Westin B., 1971, Busto, R., 1989). 
The mechanisms underlying the protective effect of hypothermia are not clear. It is possible that one of the protective mechanisms in the hippocampus is a reduction of the normal synaptic drive on CA1 from the perforant path and CA3 (resulting in less glutamate release) at a time when these neurones are a reduction of the normal synaptic drive on CA1 from the perforant path and $\mathrm{CA} 3$ (resulting in less glutamate release) at a time when these neurones are in a highly vulnerable states. Perhaps, the prolonged duration of hypothermia also helped the cell to recover normal $\mathrm{Ca}^{2+}$ homeostasis. (Colbourne F., 1994). A decrease in metabolic demands takes place when body temperature is lowered, so that subsequent toxic effects are weakened and survival to prolonged exposure to asphyxia is ensured without permanent brain lesions.

The functional consequences that result from striatal and cortical NO-containing cytomegalic neurons after an episode of subsevere or severe PA remain to be determined. Further studies on cold therapy in the treatment of severe asphyxia in newborn should be carried out without delay.

In summary, the present findings demonstrate that an inappropriate activation of NOS enhanced in striatal and cortical neurons secondary to chronic PA in the presence of subsevere severe lack of oxygen is closely associated with ischemic neuronal injury Moreover this study shows that hypothermia reduced neuronal darnage suggesting that it may be a useful therapeutic following ischemic injury.

\section{ACKNOWLEDGEMENTS}

We would tike to express our gratitude for the excellent technicall assistance of Mrs: Emerita Jorge Vilela de Banchieri. This work was supported by grants from the University of Buenos Aires (U.B.A.) and the National Research Council (C.O.N.I.C.E.T.), Argentina. 


\section{REFERENCES}

Bjelke B, Andersson K, Ogren S.O. and Bolme P. (1991), Asphyictic lesion. proliferation of tyrosine hidroxilase-immunoreactive nerve cell bodies in the rat substancia nigra and functional changes in dopamine peurotransmission, Brain Res., 543, 1-9.

Busto R. Dietrich W.D., Globus M. Y.-T, Valdes I., Scheinberg P. and Ginsberg M. D. (1987). Small differences in intra-ischemic brain temperature critically determine the extent of ischemic neuronal injury, $J$. Cereb. Blood. Flow. Metab., 7, 729-738.

Busto, R. Dietrich, W.D., Globus, M. Y. T. \& Ginsberg, M.D. (1989) Post ischemic moderate hypothermia inhibits CAl hippocampal ischemic neuronal injury, Neuroscience Letter, 101, 299-303.

Clifton G, Taft W, Blair R.E., Choi S.C., and DeLorenzo, R.J. (1989) Conditions for pharmacologic evaluation in the gerbil model of forebrain ischemia, Stroke, 20, $1545-1552$

Colbourne F., \& Corbett D. (1994). Delayed and prolonged post-ischemic hypothermia is neuroprotective in the gerbil, Brain Research, 654, 265-272

Dunn J.M. and Miller J.A. Jr.(1969). Hypothermic combined with positive pressure ventilation in resuscitation of the asphyxiated neonate. Amer. J. Obstet. Gynec.. $104,58-67$.

Ferrante R, Kowall N., Beal M., Beal M.F., Richardson E.P.Jr, Bird E.D. and Martin I.B. (1985). Selective Sparing of a Class of 'Striatal Neurons in Huntington's Disease, Science, $230,561-563$ 
Globus M., Ginsberg M., Dietrich W., Busto R. and Scheinberg P.(1987). Substantia nigra lesion protects against ischemic damage in the striatum, Neurosci. Lett, 80, 251-256.

Globus M., Busto R., Dietrich W., Martinez E, Valdés I. and Ginsberg M.(1988). Effect of ischemia on the in vivo release of striatal dopamine, glutamate and GABA studied by intracerebral microdialysis, J. Neurochem., 51 , 1455-1464.

González-Aguilar, F, De Robertis E.(1963). A formalin perfusion fixation method histophysiological study' of the central nervous system with electrn microscopy. Neurology, 13, 758-771.

Green, E.J., Dietrich, W.D., Van Djik, F., Busto, R., Markgraf, C.G., Mc Cabe, P.M. Ginsberg, MD \& Schneuderman, N (1992). Protective effects of brain hypothermia on behavior and histopathology following global cerebral ischemia in ratas, Brain Research, 580, 197-204.

Hanbauer I, Wink D., Osawa I.,Edelman G, and Gally J (1992). Role of nitric oxide in NMDA-evoked release of ${ }^{3} \mathrm{H}$-dopamine from striatal slices, NeuroReport, 3 409412

Herrera-Marschitz M., Loidl C.F., You Z.B. Andersson K., Silveira R., O'Connor W.T. and Goiny M.(1994). Neurocircuity of the Basal Ganglia Studied by Monitoring Neu rotransmitter Release, Molec. Neurobiol., 9, 17!-182.

Hope B., Michael G., Knigge K. and Vicent S.(1991). Neuronal NADPH-diaphorase is a nitric syntethase, Proc. Natl. Acad. Sci. USSA, 88, 2811-2814.

Inagaki S., Suzuki K., Taniguchi N and Takagi H.(1991), Localization of Mnsuperoxide dismutase (Mn SOD) in cholinergic and somatostin-containing neurons in the rat neostriatum, Brain Res., 549, 174-177 
Kirino, T.(1982). Delayed neuronal death in the gerbil hippocampus following ischemia. Brain Research, 239, 57-69.

Loidl C.F., Herrera-Marschitz M., Andersson K, You Z.B.,Goiny M,O'Connor W.T.,Bjelke B. and Ungerstedt U.(1993). Short and long-term effects of perinatal asphy xia in rats monitored with peripheral and intracerebral microdialysis, Amino Acids, 5, 167.

Loidl, C.F., Herrera-Marschitz, M., Andersson, K., You, Z.B., Goiny, M, O'Connor, W.T., Bjelke, B. \& Ungerstedt, U. (1993). Short and long-term effects of perinatal asphyxia in ratas monitored with peripheral and intracerebral microdialysis, AminoAcids, 5, 167.

Loidl C.F., Herrera-Marschitz M., Andersson K.You Z.B.,Goiny M, O'Connor W.T, Silveira R., Rawal R., Bjelke B., Chen Y. and Ungerstedt U.(1995). Long-term effects perinatal asphyxia on basal ganglia neurotransmitter systems studied with microdialysis in rat, Neurosci. Lett., 175, 9-12

Loidl, C.F., Capani, F., López-Costa J.J. and Pecci Saavedra J., Neuroscience Society. Abstract, 1995, pag., 191

Loidl, C.F., Capani, F., López-Costa J.J. , Selvin-Testa A. and J. Pecci Saavedra. (1996). Striatal Cytomegalic neurones containing nitric oxide are associated with experimental perinatal asphyxia: implication of cold treatment, Medicina, 56:169172

Miller J.A. Jr..(1971). New approaches to preventing brain damage during asphyxia, Am. J. Obstet. Gynecol, 110,1125-1133. 
Mischel P., Nguyen L. and Vinters H., Cerebral cortical dysplasia associated with pediatric epilepsy.(1995). Review of neuropathologic features and proposal for grading system, J. Neuropathol. Exp. Neurol., 54, 137-153.

Mufson E., and Brandabur M.(1994). Sparing of NADPH-diaphorase striatal neurons in Parkinson's and Alzheimer's diseases, NeuroReport, 5, 705-708.

Palmer R., Ferrige A. and Moncada S. (1987). Nitric oxide release accounts for the biological activity of endothelium-derived relaxing factor, Nature, 327, 524526.

Paschen, W. (1989) Molecular mechanism of selective vulnerability of the brain to ischemia, Circ. Metab. Cerveau, 6,115-139.

Pasternak J., Predey T. and Michael M.(199i). Neonatal asphyxia: vulnerability of basal ganglia, thalamus and brainstem, Pediatr. Neurol., 7, 147-149.

Paxinos G., and Watson C., The rat Brain in Stereotaxic Coordinates. Acedemic Press. San Diego California. 1986

Percy A. Neonatal asphyxia and static encephalopathies. In: Fishman MA, ed Pediatric Neurology. Grune \& Stratton Inc., 1986, pag. 57-70

Pulsinelli, W.A., Brierlet, J.B. \& Plum F. (1982). Temporal profile of neuronal damage in a model of transient forebrain ischernia, Anmual Neurology, 11, 491-498.

Schuman E. and Madison D.,(1994) Nitric oxide and synaptic function, Annu. Rev. Neurosci, 17,153-183

Uemura I., Kowall N.and Beal M.(1990). Selective of NADPH-diaphorase-somatostatinneuropeptide $\mathrm{Y}$ neurons in ischemic gerbil striatum, Ann. Neurol., 27, 620-625. 
Valtschanoff, J.G, Weinberg, J.R, Kharazia, V., Nakane, M and Schmidt, H. (1993).Neurones in Rat Hippocampus that Synthesize Nitric Oxide. The Journal of Comparative Neurology, 331, 111-121.

Vincent S. and Kimura H.(1992). Fistochemical mapping of nitric oxide synthase in the rat brain, Neurascience, 46, 755-784.

Vincent S. and Hope B. (1992). Neurons that say NO, TINS, 15 , 108-113.

Volpe J. Neurology of the newborn, WB Saunders, Philadelphia, 1987.

Westin B.(1971). Infant resuscitation and prevention of mental retardation, Am. J. Obstet. Gynecol., 110, 1134-1138.

Zhu X. and Luo L.(1990) Effect of nitroprusside (nitric oxide) on endogenous dopamine release from rat striatal slices, $J$. Neurochem., $59,932-935$. 


\section{LEGENDS TO FIGURES}

Fig. 1: Photomicrographs of striatal NADPH-d(+) neurons from 6-month-old rats in sections from (a) control, (b) severe perinatal asphyxia (PA) and (c) 100min of PA at $15^{\circ} \mathrm{C}$. Note cytomegalic soma and dendritic branches of a severe PA neuron (arrows) compared to control and PA-H cells. All cells at same magnification. Scale bar: 10ym.

Fig. 2: Photomicrographs of cortical NADPH-d(+) neurons from 6-month-old rats in sections from (a) control, (b) severe PA and (c) $100 \mathrm{~min}$ of PA at $15^{\circ} \mathrm{C}$. Note cytomegalic soma and tortuous dendritic branches of a severe PA neuron (arrows) compared to control and PA-H cells. All cells at same magnification. Scale bar $10 \mu \mathrm{m}$

Fig. 3: Measurement of striatal NADPH-d(+) cell area (a), cell perimeter (b) and Fshape (c), in 6-month-old rats subjected to different periods of PA at $37^{\circ} \mathrm{C}$ or $15^{\circ} \mathrm{C}$. Each value presents mean $\pm \mathrm{SD}$ (vertical lines) of determinations made from $n=100$ cells from each group. Asterisk indicates that differences in $\mathrm{NADPH}-\mathrm{d}(+)$ cells in these two groups were highly significant $(p<0.001)$ compared with the remainder. Statistical analysis was performed by ANOVA test. There were no significant differences between subsevere and severe PA. No significant differences in F-shape (c) were found for any groups inter se. 
Fig 4: Measurement of cortical NADPH-d( + ) cell area (a), cell perimeter (b) and Fshape (c), in 6-month-old rats subjected to different periods of PA at $37^{\circ} \mathrm{C}$ or $15^{\circ} \mathrm{C}$. Data are means $\pm S D$ (in vertical lines) of determinations made fromn=100 cells from each group. Asterisk indicates that differences in NADPH-d $(+)$ cells in these two groups were highly significant $(p<0.001)$ compared with the remainder (ANOVA test). There were no significant differences between subsevere and severe PA groups. No significant differences in F-shape (c) were found in any groups inter se. 
Table 1. Number of neurones tained in the Striatum with NADPH-diaphorase techniques and arphyctic goups.

\begin{tabular}{|c|c|c|}
\hline Region & Asphyctic time & Cell Number per field \\
\hline & Control & $3.9 \pm 1.19$ \\
\hline & 5. $37^{*}$ & $4.1 \pm 1.19$ \\
\hline & $10^{\circ} 37^{\circ}$ & $4.2 \pm 1.03$ \\
\hline & $15: 37$ & $3.9 \pm 1.07$ \\
\hline \multirow[t]{4}{*}{ Striatum Dorsal } & $19^{*} 37^{\circ}$ & $4.1 \pm 1.19$ \\
\hline & $20^{*} 37^{*}$ & $3.9 \pm 1.07$ \\
\hline & Hypothermia $20^{\circ} 15^{\circ}$ & $3.8 \pm: 1.03$ \\
\hline & Hypothermia $100^{\circ} 15^{\circ}$ & $3.9 \pm 1.19$ \\
\hline \multirow[t]{8}{*}{ Ventral Striafum } & Control & $4.1 \pm 1.08$ \\
\hline & 5. 37 & $3.9 \pm 1.10$ \\
\hline & $10^{*} 37 *$ & $4.1 \pm 1.0 .9$ \\
\hline & $15^{\circ} 37^{*}$ & $3.9 \pm 1.10$ \\
\hline & $19^{*} 37$ & $3.8 \pm 1.03$ \\
\hline & $20^{*} 37^{\circ}$ & $4.5 \pm 1.08$ \\
\hline & Hypothermia $20^{\circ} 15^{\circ}$ & $4.2 \pm 1.09$ \\
\hline & Hypothermia $100^{\circ} 15^{\circ}$ & $4.1=1.12$ \\
\hline \multirow[t]{8}{*}{ Medial Striatum } & Control & $3.9=1.07$ \\
\hline & $5^{*} 37^{*}$ & $3.8 \div 1.08$ \\
\hline & $10^{\circ} 37$ & $3.9 \pm 1.07$ \\
\hline & $15^{\circ} 37^{*}$ & $3.9 \div 1.14$ \\
\hline & $19^{*} 37$ & $3.91=1.08$ \\
\hline & $20^{\prime} 37^{\circ}$ & $3.6 \pm 1.07$ \\
\hline & Hypothermia 20" $15^{\circ}$ & $4.1 \div 1.07$ \\
\hline & Hypothermis $100^{\circ} 15^{\circ}$ & $4.1 \pm 1.04$ \\
\hline \multirow[t]{8}{*}{ Striatum Lateral } & Control & $3.8 \pm 1.09$ \\
\hline & 5' 37 & $3.9 \pm 0.97$ \\
\hline & $10 * 37 *$ & $4.1 \pm 1.05$ \\
\hline & $15: 37 \%$ & $3.9=1.07$ \\
\hline & $19^{\circ} 37^{*}$ & $4.1 \pm 1.05$ \\
\hline & $20 * 37$ & $4.3=0.94$ \\
\hline & Hypothermia $20^{\circ} 15^{\circ}$ & $3.9=0.94$ \\
\hline & Hypothermia $100^{\circ} 15^{\circ}$ & $39 \div 1.17$ \\
\hline
\end{tabular}




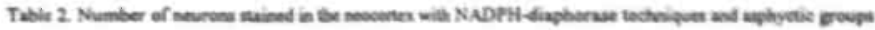

\begin{tabular}{|c|c|c|}
\hline Regon & Auphoctse time & Call number per field \\
\hline \multirow[t]{12}{*}{ Leteral Neocontex } & Conturel & $3.7 \pm 0.94$ \\
\hline & $5 \cdot 37$ & $4.3 \pm 0.98$ \\
\hline & $10^{\circ} 37^{\circ}$ & $3.6 \pm 1.06$ \\
\hline & $15 \cdot 37 *$ & $3.5 \pm 0.5$ \\
\hline & $19^{*} 37^{\circ}$ & $4.2 \pm 0.98$ \\
\hline & $20^{*} 37^{*}$ & $3.7 \geq 0.94$ \\
\hline & Hopolemsia $20^{\circ} \quad 15^{\circ}$ & $4.1=0.97$ \\
\hline & Hypothermia $100^{\circ} 15^{*}$ & $4.3 \pm 0.98$ \\
\hline & Centrel & $4.1+0.1$ \\
\hline & 5) 37 & $38 \pm 0.91$ \\
\hline & $10^{\prime} 37$ & $3.7 \pm 0.97$ \\
\hline & $15 * 37 *$ & $4.1 \geq 0.99$ \\
\hline \multirow[t]{4}{*}{ Medial Neocontex } & $19: 37$ & $42 \geq 0.84$ \\
\hline & $20: 37$ & $3.6 \geq 0.84$ \\
\hline & Hypethermia $20^{\circ}$ is" & $4.3+0.87$ \\
\hline & Hypechermia $100^{\prime} 15^{\circ}$ & $4.1 \pm 0.99$ \\
\hline
\end{tabular}


Table. 3 Striatum cells counts at $8.6 \mathrm{~mm}$ and $0.40 \mathrm{~mm}$ to bregma.

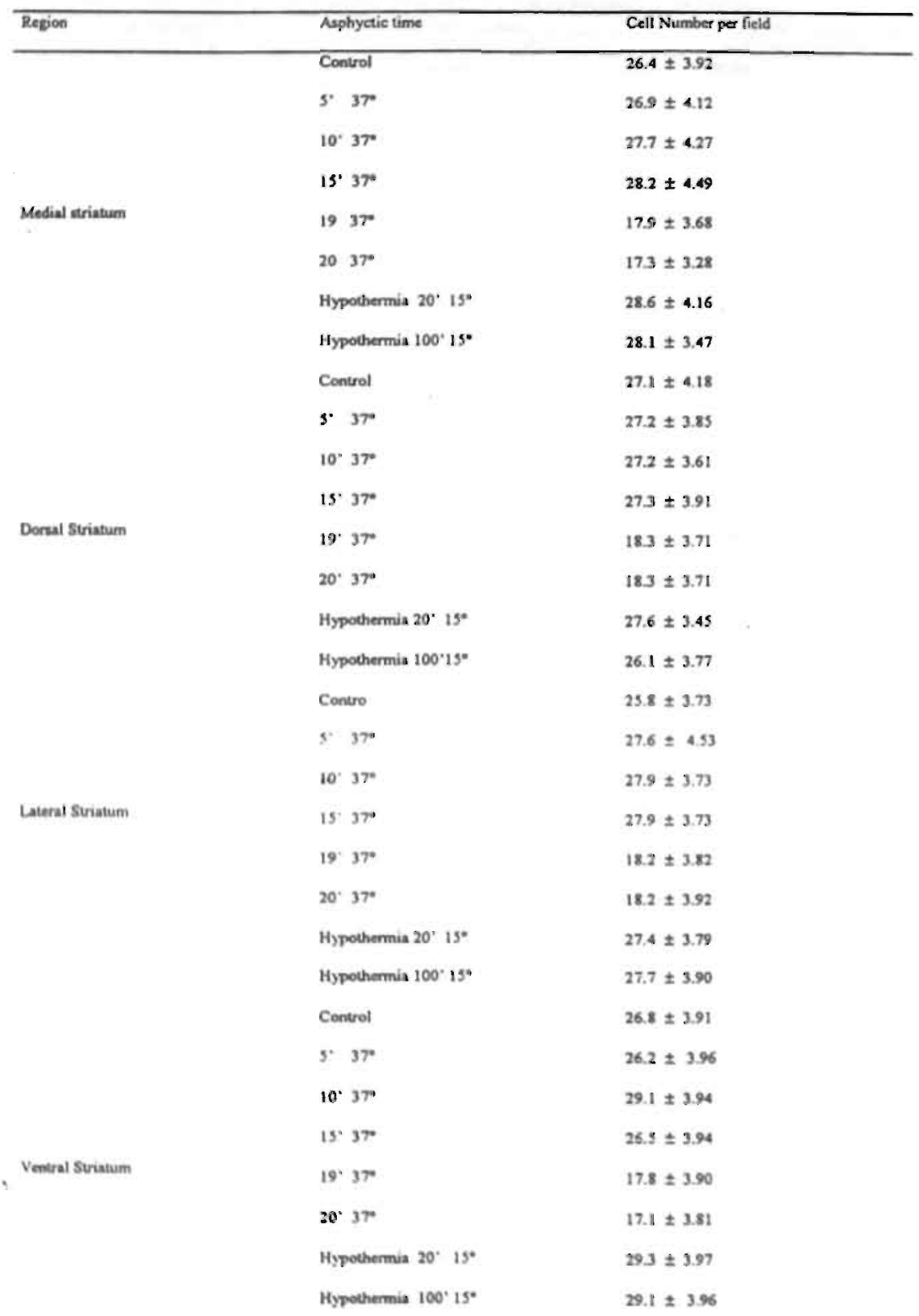




\begin{tabular}{|c|c|c|}
\hline Regen & Ayphictic Time & Celi namber per field \\
\hline \multirow[t]{8}{*}{ Laleral neocertex } & Cened & $35.2=4.19$ \\
\hline & $57 \%$ & $39.7 \pm 4.43$ \\
\hline & $10^{\circ} 37$ & $39.2 \pm 4.07$ \\
\hline & $15 \cdot 37$ & $35.7 \geq 3.92$ \\
\hline & $19 \cdot 37$ & $273+3.56$ \\
\hline & $20^{\prime} \mathbf{3 7}$ & $269 \pm 367$ \\
\hline & Mypothermia 20' $15^{\circ}$ & $35.2 \div 3.98$ \\
\hline & Hypelemia $100^{\circ} 15^{\circ}$ & $363=3.76$ \\
\hline \multirow[t]{8}{*}{ Medial necconex } & Conven & $38.1=3.14$ \\
\hline & 5' 37 & $37.4=3.06$ \\
\hline & $10^{\circ} 37$ & $37.3 \pm 3.19$ \\
\hline & $15^{*} 37 *$ & $371=3.95$ \\
\hline & $19^{*} 37^{*}$ & $31.1=3.78$ \\
\hline & $20^{\circ} 37$ & $317+3.12$ \\
\hline & Hypechersia 20' $15^{\circ}$ & $396 \div 3.7$ \\
\hline & Hypothemin $100^{\prime} 15^{*}$ & $39.9 \pm 3.77$ \\
\hline
\end{tabular}




\section{STRIATUM}
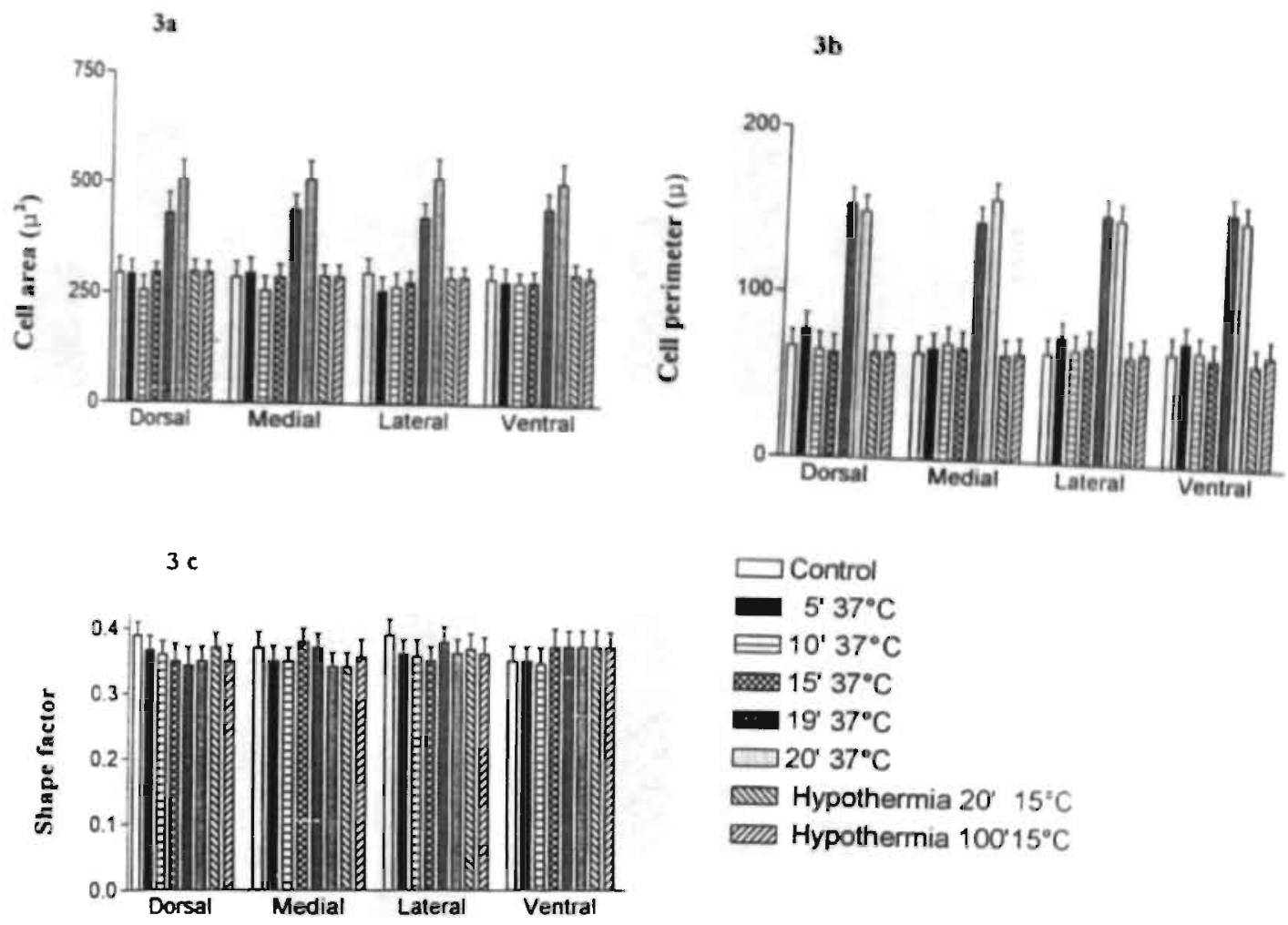

बiv Hypothermia 20 $15^{\circ} \mathrm{C}$

ams Hypotherrnia $100^{\prime} 15^{\circ} \mathrm{C}$ 


\section{STRIATUM}
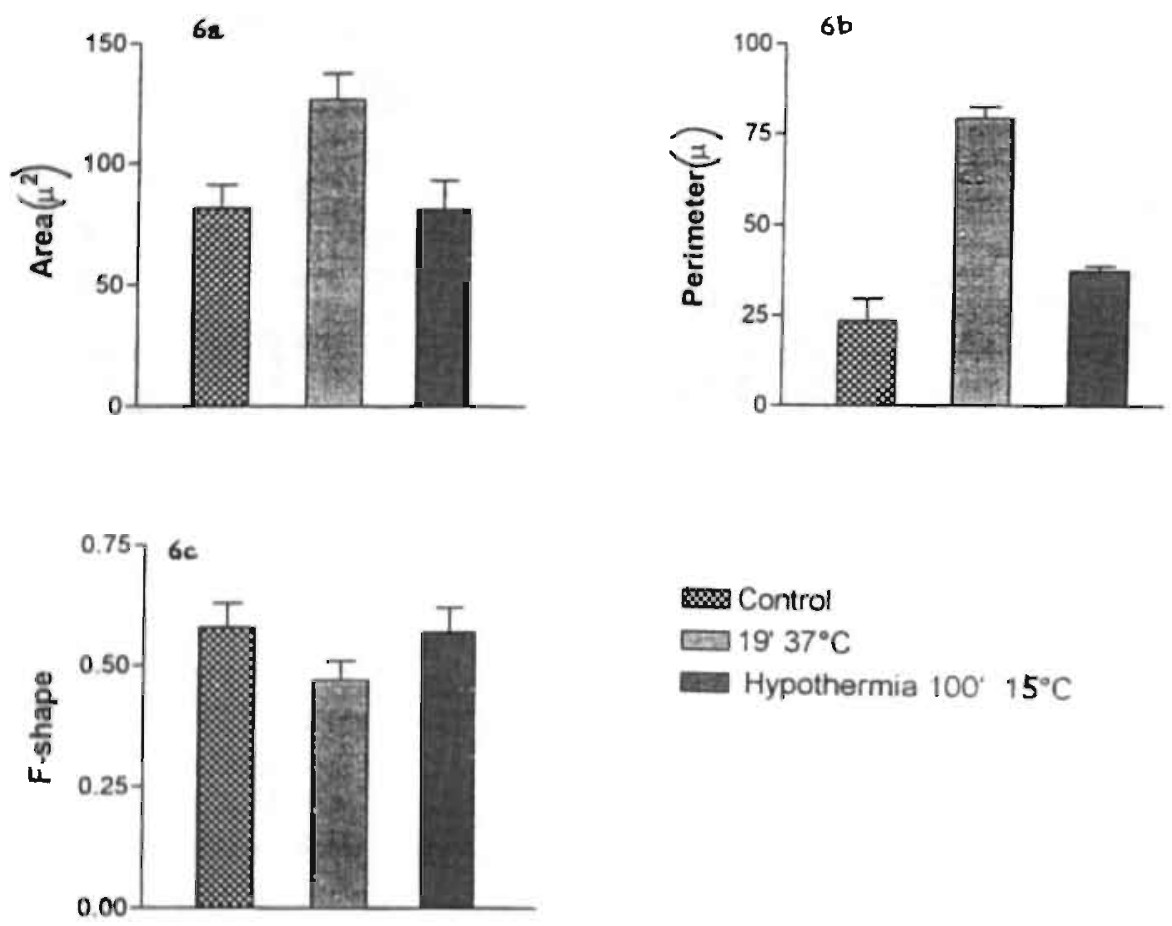

Control

ए $19^{\prime} 37^{\circ} \mathrm{C}$

Hypothermia $100^{\circ} 15^{\circ} \mathrm{C}$ 


\section{NEOCORTEX}
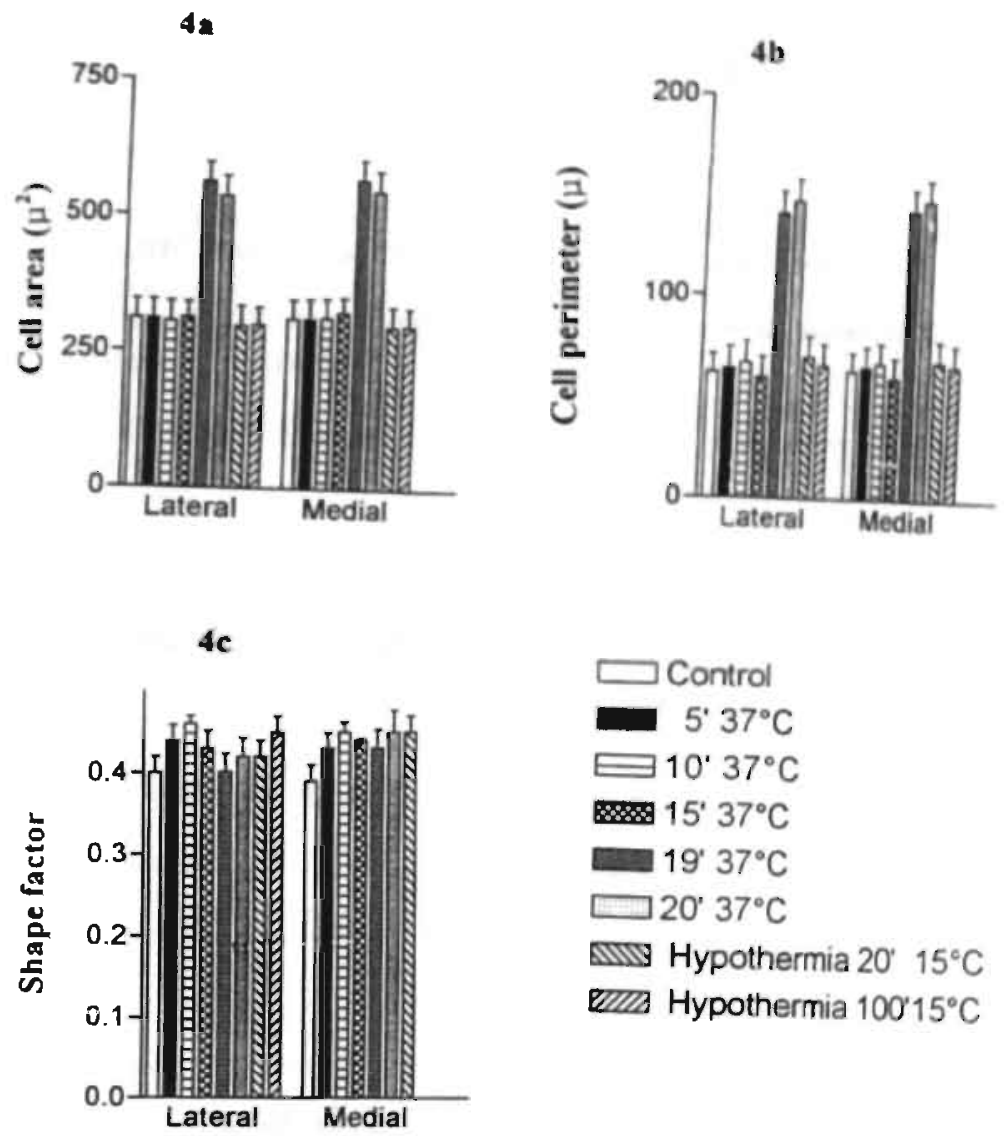

$\square$ Control

प $5^{\prime} 37^{\circ} \mathrm{C}$

$\rightleftarrows 10^{\circ} 37^{\circ} \mathrm{C}$

18: $15^{\circ} 37^{\circ} \mathrm{C}$

$19^{\prime} 37^{\circ} \mathrm{C}$

$\square 20^{\prime} 37^{\circ} \mathrm{C}$

aId Hypothermia $20^{\prime} 15^{\circ} \mathrm{C}$

exa Hypothermia $100^{\prime} 15^{\circ} \mathrm{C}$ 
SHORT TERM CHANGES IN NADPH-DLAPBORASE REACTIVTTY IN RAT BRANN FOLLOWING PERTATAL ASPAYXIA: NEUROPROTECTIVE EFFECTS OF COLD TREATMENT.

Loidi, C. Fabiän; Capani, Francisco; López-Costa, Juan José; Selvín-Testa, Asia; López, Ester M and Pecci-Sanvedra, Jorge*

Instituto de Biologia Celular y Neurociencias “Prof. E. De Robertis" and LANAIS-MUE, Facultad de Medicina, Universidad de Buenos Aires (1121) Paraguay $21553^{\circ}$, Buenos Aires, Argentina.

\section{- Corresponding Author}

Frof. Dr. Jorge Pecci Shavedra

Instituto de Biologia Celular y Neurocieincias "Prof. Eduardo De Robertis"und LANAIS-MTE, Facultad de Medicina, Universidad de Buenos Aires, Paraguay $21553^{\text {rd }}$ (1121) Buenos Aires, Argeatina.

FAX: 54-1785-2164

PHONE: 54-1-961-5010. Ext. 17,26.

E-mail: ritagfenuba.sid.ar 
SUMMURY: Perinatal asphyxia (PA) produces changes in nitric oxide synthase (NOS) activity in neuronal and endothelial cells of the striatum and neocortex. The changes were examined using histochemical NADPH-diaphorase staining method. New born rats were exposed to severe PA at $37^{\circ} \mathrm{C}$ and another groups was subjected to severe PA under hypothermic condition $\left(15^{\circ} \mathrm{C}\right)$ for 20 or $100 \mathrm{~min}$. Quantitative image analysis was performed on striatal and neocortex in order to count cell number of reactive neurons and to compare the pattern of staining between the different groups of animals. Severe asphyctic pups showed an important neuronal loss in striatum and neocortex, that was reduced by hypothermia. NADPHd(+) neurons with reactive processes were found in the lateral zone of the striatum and neocortex in asphyctic pups. Controls and hypothermic striatum showed rounded cells without reactive process while no cells were stained in cortex. There was also an increase in NADPHd activity in endothelial cells in severe asphyctic pups in striatum and neocortex versus control and hypothermic treated animals. Our data evidenced that an inappropriate activation of NOS in neuronal and endothelial cells induced by PA is related with neuronal injury. Hypothermia inhibits neuronal injury and may be a valuable neuroprotective agent.

KEY WORDS: Hypachenmia - NADPH diaphorase - Perinatal asphyxia - Striatum - Cortex - Newborn rats 


\section{I- INTRODUCTION}

Asphyxia during birth is an important cause of perinatal mortality and neurology morbidity. Several organs may be affected during ischernia renal and cerebral injuries being the most common. (Williams, et al, 1992). Perinatal asphyxia (PA) is the main cause of cerebral hypoxia during ante and intra-partum. Although some infants recover completely from an asphyctic episode, others can develop permanent deficits such as hyperactivity syndrome, epilepsy, mental retardation or cerebral palsy (Volpe, 1987). The regions that. are particularly sensitive to injury include layer 3-5 of the cortex, hippocampus (CA.1 and CA.4), striatum, thalamus, rnedial geniculate nucleus (MGN) and substantia nigra reticulata (Snr) (Garcią et al, 1989, Meyer, 1989, Hossman, 1991). Although the mechanism responsible: for this selective vulnerability is not well known (Pastchen, 1992) a brief event of global ischemia produce neurotransmitter alterations, e.g in striatum and neocortex . (Bjelke et al, 1991, Herrera-Marschitz et al, 1993, Loidl et al, 1994)

It has been shown using animal experimental models of cerebral ischemia that decreases in brain temperature confer striking protection against ischemic neuronal injury (Grinsberg, et al 1992, Green, et al, 1992, Loidl et al, 1996). In previous reports we. have demonstrated the important rol of hypothermia in animal survival after the induction of PA. While $100 \%$ of survival was observed up to $16 \mathrm{~min}$. of asphyxia when PA was induced at normal temperature $\left(37^{\circ} \mathrm{C}\right)$ and no survival was seen after $22 \mathrm{~min}$ of asphyxia at the same temperature, on the opposite $100 \%$ survival was observed after $100 \mathrm{~min}$. of asphyxia when PA was performed at low temperature $\left(15^{\circ} \mathrm{C}\right)$ ( Herrera Marschitz et al 1993, Loidl et al, 1995). 
The precise cascade of events leading to secondary damage is unclear, although multiple mechanisms have been implicated. At the biochemical level, excitatory amino acids, (Choi, 1990) intracellular calcium accumulation,(Siesjo \& Bengtsson, 1989) and increased free radical production are involved (Pellegrini-Giampietro,et al 1990). At the cellular level, apoptosis (programmed cell death) due to deprivation of growth factors and activity of inflammatory cells may play important roles. (Edwards, et al, 1995). Nitric oxide, initially identified as an endothelial-derived relaxing factor ( Palmer et al., 1987), has been involved in the pathogenesis of brain injury (Moncada et al, 1990). NO reacts with superoxide anion to originate peroxinitrite anion (ONOO), which in a protonate form, decays rapidly to form highly reactive radicals including hydroxyl radical $(\mathrm{OH})$ and nitrogen dioxide $\left(\mathrm{NO}_{2}\right)$ (Beckman et al, 1990). Furthermore, the excess of nitric oxide per se can be toxic to neurons (Garthwaite, J. 1991). The NOS possesses a NADPH binding site responsible of the diaphorase activity (Dawson and Snyder, 1994). making it possible to be detected by a histochemical reaction

Therefore the relationship between the development of ischemic neuronal injury and NO production was examined following perinatal asphyxia in an attempt to clarify the role of NO in the generation of ischemic brain injury. In the present study NOS activity was investigated in neuronal cells of the striatum and neocortex, know to be the most winerable to a PA (Pasternak et al, 1991). In addition, immediately delivered pups that suffered severe PA were compared with asphyctic animals treated with hypothermia. 


\section{2-MATERIAL AND METHODS}

\section{Subjects}

Fifty-two Sprague-Dawley pregnant rats (Certified Colony) and thirty postischemic male rats were purchased from the Breeding Animal Laboratory of the School of Biochemistry, and included in this study. The dams were bred by housing, three of them with one male until they were sperm positive as determined by vaginal smear. Pregnant rats were kept in individual stain-less steel cages and fed with Purine chow and tap water ad libitum. The $21^{*}$ day following the original mating, individual female were placed in separate cages.

\section{Induction of asphyxia}

Asphyxia was induced in pups delivered by caesarean operations on pregnant rats. Gestational age was determined by vaginal smear Rats within the last day of gestation were anaesthetised by i.p. injection of $28 \%$ (w/v) chlorall hydrate (Merck) $0.1 \mathrm{~m} / 100 \mathrm{~g}$ of body weight. Their entire uteri containing the foetuses were taken out by hysterectomy, and placed in a bath water at $37^{\circ} \mathrm{C}$ during $20 \mathrm{~min}$. (severe asphyxia) (Herrera-Marschitz et. al., 1993) or at $15^{\circ} \mathrm{C}$ for 20 and $100 \mathrm{~min}$ Caesarean-delivered control and asphyctic pups were obtained from the same mother. Following asphyxia, the uterus horns were rapidly opened and the pups removed and stimulated to breathe on a heating pad by cleaning off the delivery fluid and by tactile stimulation with small pieces of medical wipes.

Some survival asphyctic and caesarean delivered control pups (10 in each group) were decapitated following $30 \mathrm{~min}$ of recovery after birth, period during which survival, gasping, respiratory frequency, vocalisation, colour of the skin and spontaneous 
movements were recorded. Animals used for morphological studies were killed and brains were fixed by immersion during 2 hs, with $4 \%$ paraformaldehyde in $0.1 \mathrm{M}$ phosphate buffer, pH 7.4. After fixation, brains were cut on a Leitz cryostat and $20 \mu \mathrm{m}$ sections mounted on gelatine -coated glass slides.

\section{Histochemistry}

Sections from treated (PA, PA + hypothermia) and control animals were processed using the NADPH-d histochemical method (Vincent and Kimura, 1992). Briefly, sections were incubated for $1 \mathrm{~h}$ at $37^{\circ} \mathrm{C}$ in the same reaction mixture containing $0.1 \% \mathrm{NADPH}$ and $0.02 \%$ nitroblue tetrazolium diluted in $0.1 \mathrm{M}$ phospate buffer with $0.3 \%$ Triton X-100 (all reagents were purchased from Sigma). Sections were mounted in PBS/glycerol (1:3) observed and photographed with a Zeiss Axiophot microscope. In absence of $\beta$ - NADPH, cells were not stained. When it were substituted NADPH for NADP nonspecific staining resulted in the entire section. Nitroblue tetrazolium contains a monoformazan impurity that gives a diffuse purple background (Valtschanoff, et. al., 1993); to remove this background, some sections were incubated in acetone dimethyl sulfoxide for 10 minutes before mounting.

\section{Bistology}

Rats subjected to $30 \mathrm{~min}$. of PA or PA + hypothermia were anaesthetised with $28 \%(w / v)$ chloral hydrate, $0.1 \mathrm{~m} / / 100 \mathrm{~g}$ of body weight and decapitated. Adjacent

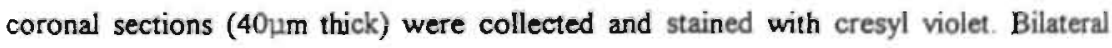
counts of neurons (well defined nucleus, distinct cellular membrane and not shrunken) were performed by an observer blind to treatment conditions. 
Neurons were counted in the lateral, medial, dorsal and ventral striatum neurons and in the medial and lateral sectors of neocortex following the Paxinos Atlas. (Paxinos 1993),

\section{Computerized Image Analysis}

Selected brain sections of the NADPHd $(+)$ and cresyl violet stained neurons of different groups, were measured by using a computerised image analyser (KONTRONZEISS VIDAS). Selected fields were located in the lateral sectors of neocortex. Sections of $40 \mu \mathrm{m}$ thick with adequate labelling of NADPHd were randomly selected from coded slides ( 6 for each of considered groups). Data from 50 selected striatum and surrounding neocortex were averaged for each animal. Ten cells per sections were analysed (total: 100 cells per group). Light microscope images were transferred by a video camera connected to an interactive image analysis system on line. (KONTRON ZEISS VIDAS) . The images were digitised into an array of $512 \times 512$ pixels corresponding to $140 \times 140$ $\mu \mathrm{m}$ ( 40X primary magnification). The resolution of each pixel was 256 grey levels (8 grey bits level resolution). After automatic normalization of grey-scale, interactive delineation and contrast enhancement of the neuronal image were performed, following the removal of interfering non specific images. Morphometric parameters (area, perimeter, maximum and minimum diameter, shape factor) from NADPHd (+) neurons in sections of experimental and control groups were measured. The mean and SD were calculated in treated and control groups

The spatial distribution of $\mathrm{NADPHd}(+)$ and cresyl violet staining neurons were counted using VIDEOPLAN image analysis system. They were digitised into 256 grey levels in measuring fields, $215 \times 180 \mu \mathrm{m}$ in size (20X primary magnification). NADPH 
$(+)$ cells count per measuring field were performed. The mean and SD were calculated in the different fields from asphyctic and control groups.

\section{$\underline{\text { Statistical Analysis }}$}

Differences between means and SD of the experimental and control groups were analysed statistically using one-way analysis of variance (ANOVA) and subsequently the Newman-Keuls test, with a p value of less than 0.05 being considered significant ANOVA and Newman-Keuls test were routinely performed on an IBM compatible PC AT486 package software (primer, Mc Graw Hill, Inc.) 


\section{RESULTS}

\section{Survival and early behaviour.}

Rats subjected to $>20$ min of PA were considered severe asphyctic animals. As showed in previous reports (Herrera-Marschitz et al, 1993, Loidl et al, 1993, 1994) a. drastic decrease of survival (about $80 \%$ ) and deteriorated physiological conditions were observed in this group of animals in comparison with the controls (presence of gasping, decrease in respiratory frequency and vocalization, akinesia and pale - skin). No pups survived more than $22 \mathrm{~min}$ of asphyxia, but at $15^{\circ} \mathrm{C}, 100 \%$ survived without behavioural differences with the control group. After $20 \mathrm{~min}$. and $100 \mathrm{~min}$ of PA at $15^{\circ} \mathrm{C}$ all pups survived after intense manual stimulation but showed gasping, decrease in respiratory frequency, no vocalișation, pale skin and akinesia.

\section{Cresyl Violet staining in the striatum}

Normothermic $\left(37^{\circ}\right)$ severe asphyctic animals exhibited nearly $50 \%$ neuronal loss in striatum. Hypothermia $\left(15^{\circ} \mathrm{C}\right)$ resulted in virtually no striatum neuronal injury as was also the case in the control animals. Table 1 summarizes the values of striatum neuronal counting and the estimate of neuronal loss in striatum of normothermic and hypothermic ischemic group. Normothermic animals exhibited significantly greater neuronal loss in striatum than hypothermic ischemic animals $(\mathrm{P}>0.001)$. When compared different regions of the striatum (ventral, dorsal, lateral, medial) no significant differences were found. (Table 1) 


\section{NADPE histochemical staining in striatum asphyctic new-born rats:}

Pups exposed to severe PA, control PA + hypothermic conditions showed NADPHd $(+)$ cells in the lateral zone of the striatum (Fig. 1). In control pups, obtained by caesarea or by natural delivery, the NADPH-d $(+)$ cells stained only the soma but not the processes (Fig. 2a). Animals exposed to severe asphyxia exhibited NADPH-d $(+)$ neurons with highly reactive processes (Fig 2b). Animals exposed to PA for $20 \mathrm{~min}$. and $100 \mathrm{~min}$ in hypothermic at $15^{\circ} \mathrm{C}$ ( Fig. 2c) showed the same partern of staining than controls. Striatum cell ares and perimeter increased significantly in rats exposed to severe asphyxia in comparison with control and $\mathrm{PA}+$ hypothermia $15^{\circ} \mathrm{C}$ treated animals during $20 \mathrm{~min}$. and $100 \mathrm{~min}$. (see Fig. 6a, 6b, 6c ). There were not significant differences $(\mathrm{P}<0.001)$ in number of cells (data not shown). When different regions of the striatum (dorsal, ventral, lateral and medial) were compared no significant differences (neither in any morphologic parameter nor in the number of cells) were detected. The NADPH diaphorase activities in endothelial cells of the medium-diameter vessels were more intense than in controls.(4a, 4b) Hypothermia during 20' and $100^{\prime}$ reduced the NADPH diaphorase reactivity in endothelial cells, reaching similar levels to those observed in controls. (Fig 4c).

\section{Cresyl violet in the neocortex}

Severe normothermic $\left(37^{\circ} \mathrm{C}\right)$ asphyctic animals showed a $45 \%$ neuronal loss. Hypothermia $\left(15^{\circ} \mathrm{C}\right)$ during $20 \mathrm{~min}$. and $100 \mathrm{~min}$. reduced significantly neocortical neuronal loss $\left(\mathrm{P}^{\prime}>0.001\right)$. Table 2 showed the neocortical neuronal counting and the estimate of the neuronal loss in normothermic and hypothermic groups. Normothermic 
asphyctic animals exhibited significantly greater neuronal loss than hypothermic animals. When compared different sectors of the neocortex (lateral and medial) no significant differences were found $(\mathrm{P}>0.001)$ ( Table 2 )

\section{NADPH histochemical staining in neocortex asphyctic newborn}

Rats subjected to severe PA in parietal neocortex showed the same morphological neuronal changes as those observed in the striatum.(Fig 3b) Non- stained cells were also seen in the corex of the control and hypothermic control rats (Fig 3a, 3c). The NADPH diaphorase staining in endothelial cells of medium-diameter vessels became more intense during severe asphyxia in comparison with controls. (5a, 5b) Hypothermia at $15^{\circ} \mathrm{C}$ during $20 \mathrm{~min}$. and 100 min. reduces the $\mathrm{NADPH}-\mathrm{d}(+)$ reactivity in endothelial cells reaching similar levels to those observed in controls. 


\section{DISCUSSION}

Immediately after inducing asphyxia NADPH-d changes in the lateral zone of striatum as well as in some cortical neurons are observed. The entire cell including the soma and processes are intensely stained. Striatal NADPH-d $(+)$ neurons increase the reactivity of their processes, but were always localized in the lateral zone of the striatum, suggesting that severe PA could stimulate some kind of NADPH reactivity. An increase in NADPH-d (+) staining of the blood vessels in striatum and cortex was also observed in the severe asphyctic animals, indicating that at this early post-ischemic period, vasodilatation takes place in an effort to enhance the oxygen supply to the tissues.

The negative staining to NADPH-d in cortical neurons of control rats is in agreement with a recent report showing that this enzyme is present up to the 19th prenatal day in the rat, and decrease until day 0 postnatal (Bredt et al, 1994). In those rats in which PA was induced, some cortical granular type neurons expressed NADPH-d

Although NO synthase (NOS) has several isoforms, they may be divided into two categories with different regulatory mechanisms and activities: The constitutive $\mathrm{Ca}^{2 *}$ regulated NOS (Bredt et al, 1991) and the inducible iNOS, $\mathrm{Ca}^{2 *}=$ independent ( Xie, et al, 1992). Endothelial cell express both types of this enzyme. (Radomski et al., 1990). The cNOS in endothelial cells regulates blood vessel tone by continuously releasing NO but when there is an excess amount of NO produces an activation of endothelial INOS, (Moncada et al., 1991) leading to an inappropriate vasodilatation. This prọcess induces an increase in capillary permeability and the efflux of blood component decreasing blood 
flow (Kubes and Granger, 1992; Chi et al., 1994). These alterations in endothelial permeability may mediate edema formation and subsequently accelerate a decrease in blood flow in the area with overactivation of endothelial. NOS. In agreement with a recent report, (Nakashima, 1995) the observation that endothelial cells in the damaged striatum and neocortex exhibited a high level of NADPH-d reactivity after period of ischemia suggests a high correlation of endothelial NOS activity with the progression of neuronal loss in response to cerebral ischemia. Then, an excessive amount of endothelial NO response to a severe perinatal asphyxia seems to play a role in triggering ischemic neuronal injury.

The protective effect of hypothermia on the brain ischemia in the rat has been extensively investigated (Coimbra and Wieloch et al, 1992, Edwards et al, 1995, Loidl et al, 1996). The mechanisms of protection by hypothennia are multifactorial. (Ginsberg et al, 1992) The most important mechanisnn is a decrease in the basal metabolic rate, allowing the brain to preserve the energy (including ATR). The second probable mechanism is the reduction of the ischemia induced increase in glutamate and dopamine levels ( Busto et al, 1987). Hypothermia may attenuate the free radical increments detected in the reperfusion period after cerebral ischemia (Baiping, L., 1994). In agreement with other studies $>20 \mathrm{~min}$ (Minasawa, et al 1990, Williams C.E., et. al 199 $\mathrm{Y}$ ) of brain asphyxia caused severe neuronal, darnage in hippocampus cortex and striatum. However, under hypothermic conditions $\left(35^{\circ} \mathrm{C}, 33^{\circ} \mathrm{C}\right)$ the neuronal injury was reduced, with significant protection. Our data are consistent with the previous findings, and we now demonstrate that whole body hypothermia $15^{\circ} \mathrm{C}$ during $20 \mathrm{~min}$. and $100 \mathrm{~min}$. prevents asphyctic neuronal damage induced by $20 \mathrm{mir}$ of asphyctic ischemia in the rat. 
Hypothermia also reduces the NADPH-d reactivity of endothelial blood vessels cell protecting against neuronal damage.

Therefore, these findings demonstrate that an alteration in activation of NOS in striatum and neocortex neurons and endothelial cells is associated with PA neuronal cell damage in this regions of the brain. Moreover our data demonstrate that $15^{\circ} \mathrm{C}$ hypothermia during ischemia is remarkably beneficial and suggest that it may be of clinical use for cases of ischemic injury.

\section{ACKNOWLEDGEMENTS}

We would. like to express our gratibude to the excellent technical assistance of Mrs Emerita Jorge Vilela de Banchieri. This work was supported by UBA and CONICET, Argentina 


\section{REFERENCES}

Baiping, L., Xujuan, T., Hongwei, C., Qiming, X. and Quling, G.(1984) Effect of moderate hypothermia on lipid peroxidation in canine brain tissue after cardiac arrest and resuscitation. Stroke 25, 147-152.

Beckman, J. S., Beckman, T.W., Chen, J., Marshall, P.A. and Freeman, B. A.(1990) Apparent hydroxyl radical production by peroxynitrite: Implications for endothelial injury from nitric oxide and superoxide. Proc. Natl. Acad. Sci. USA 87,1620-1624.

Bjelke B, Andersson K, Ogren S-O and Bolme P. (1991) Asphyctic lesion: proliferation

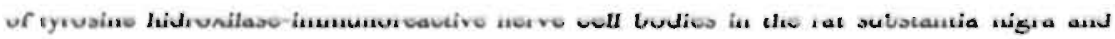
functional changes in dopamine neurotransmission. Brain Res. 543, 1-9

Bredt, Hwang P., and Snyder S. (1990) Localization of nitric oxide synthase indicating a neural role for nitric oxide. Nature $\mathbf{3 4 7}, 768-770$

Bredt DS, Hwang P.M., Glatt CE, Lowenstein SH, Clark JE, Masters: BS.(1991) Cloned and expressed rat cerebellar nitric oxide synthase structurally resembles cytochrome P450 reductase. Nature $\mathbf{3 5 1 , 7 1 4 - 8 .}$

Bredt D and Snyder S (1994) Transient nitric oxide synthase neurones in embryonic cerebral cortical plate, sensory ganglia and olfactory epithelium. Neuron 134, 30 :-313. 
Busto, R. B.S. Dietrich, D., Globus, M. Y. T. Valdes, Y. Scheinberg, P. And Ginsberg, M.D.(1987) Small differences in intraischemic temperatures critically determine the extent of ischemic neuronal injury. J. Cerebral Blood Flow Metab. 7, 200-304.

Chi, O.Z, Wei, H. M. Sinha, A. K. and Weiss, H. R. (1994) Effects of inhibition of nitric oxide synthase on blood-brain barrier transport in focal cerebral ischemia. J. Immumol $149,2736-2741$.

Choi, D.W.(1990) Cerebral hypoxia: Some new approaches and unanswered questions. J. Neurasci. 10, 2493-2501

Coimbra C. And Wieloch T. (1992) Hypothermia ameliorates neuronal survival when induced 2 hours after ischaemia in the rat. Acta Physiol. Scand. 146: 543-544

Dawson, T.M., and Snyder, S.H., (1994) Gases as biological messengers: Nitric oxide and carbon monoxide in the brain. J. Neurosci.14, 5147-5159.

Edwards, A. D, Yue X, Squier,M V, Thoresen, M, Cady E.B., Penrice J., Cooper C.E., Wyatt, J.S., Reynolds, E.O.R. and Mehmet H. (1995) Specific inhibition of apoptosis after cerebral hypoxia-ischaemia by moderate post-insult hypothermia. Bioch. and Biophy. Res. Comm. 217, 1193-1199. 
Garcia, J.H. and Anderson, ML.(1989) Pathophysiology of cerebral ischemia. CRC Crit. Rev. Neurobiol. 4, 303-324.

Garthwaite, J.(1991) Glutarnate, nitric oxide and cell cell signalling in the nervous system. TINS. 14, 60-67.

Ginsberg D. M, Linda L. Stemau, Mordecai Y.-T, Globus, Dietrich, W.D., Busto R. (1992). Therapeutic Modulation of Brain Temperature: Relevance to Ischemic Brain Injury Cerebrovasc, and Brain Metab. Rev. 4,189-225.

Green, E.J., Dietrich, W.D., Van Djik, F, Busto, R., Markgraf, C.G., Mc Cabe, P.M. Ginsberg, MD \& Schneuderman, N. (1992). Protective effects of brain hypothermia on behavior and histopathology following global cerebral ischemia in rats. Brain Res. 580, $197-204$

Herrera-Marschitz M., Loidl C.F., You Z.B. Andersson K., Silveira R., O'Connor W.T. and Goiny M.(1994). Neurocircuity of the Basal Ganglia Studied by Monitoring Neurotransmitter Release. Molec. Neurobiol, 9, 171-182.

Herrera-Marschitz M, Loidl CF, Andersson K and Ungerstedt U. (1993) Prevention of the mortality induced by perinatal asphyxia: Hypothermia or glutamate antagonism? Amino Acids 5, 413-419. 
Hope B., Michael G., Knigge K. and Vincent S. (1991) Neuronal NADPH diaphorase is a nitric oxide synthase. Proc. Natl. Acad. Sci. USA 88, 2811-2814.

Hossman, K-A.(1991) Animal models of cerebral ischemia. 1. Review of literature, Cerebrovasc. Dis. 1 (Suppl. 1), 2-15.

Kubes, P. and Granger, D.N., (1992) Nitric Oxide modulates microvascular permeability Am. J. Physiol. 262, H611-H615

Loidl CF, Herrera-Marschitz M, Andersson K, You Z-B, Goiny M, O'Connor WT, Bjelke B. and Ungerstedt U. (1993) Short and long-term effects of perinatal asphyxia in rats monitored with peripheral and intracerebral microdialysis. Amino Acids, 5, 167.

Loidl CF, Herrera-Marschitz M, Andersson K, You Z-B, Goiny M, O'Connor WT, Silveira R, Rawal R, Bjelke B, Chen Y and Ungerstedt U. (1994) Long-term effects of perinatal asphyxia on basal ganglia neurotransmitter systems studied with microdialysis in rat. Neurosci. Leti. 175, 9-12

Loidl, C.F., Capani, F., López-Costa J.J. and Pecci Saavedra J.(1995) Hypothermia prevents NADPH Diaphorase Striatal and Cortical Changes induced by perinatal asphyxia in pups and adult rats. Neuroscience Society Abstract, p. 191. 
Loidl, C.F., Capani, F., López-Costa J.J. , Selvín-Testa A. and Pecci Saavedra J.(1996). Striatal Cytomegalic neurons containing nitric oxide are associated with experimental perinatal asphyxia: implication of cold treatment. Medicina 56,169-172.

Meyer, F.B.(1989) Calcium neuronal hyperexcitability and ischemic injury. Brain Res. Rev. 14, 227-243.

Minamisawa H., Nordstrom C-H, Smith Ma, Siejo BK (1990). The influence of mild body and brain hypothernia on ischemic brain damage. J. Cereb. Bload Flow Metab. 10, 365-374.

Moncada, S. Palmer, RM. J., and Higgs, E.A. (1991). Nitric oxide: Physiology, pathophysiology, and pharmacology. Pharmacol. Rev. 43, 109-142.

Nakashima M.K, Yamashita, K, Kataoka Y., Yamashita Y.S and Niwa M.(1995) Time Course of Nitric Oxide Synthase Activity in Neuronal, Glial, and Endothelial Cells of Ratas Striatum Following Focal cerebral Ischemia, Cellular and Mol. Neurob. 15, 341 349.

Palmer, R. M. J." Ferrige, A.G., and Moncada (1987). Nitric Oxide release accounts for the biological activity of endothelium-derived relaxing-factor. Nature 327, 524-526.

Paxinos G.Aschual, W.S., and Tork Y.(1993) Atlas of the Developing Rat Nervous System, Academic Press. NJ. 
Paschen, W.(1989) Molecilar mechanisms of selective vulnerability of the brain to ischemia. Cir. Meta. Cerveau. 6: 115-139.

Pasternak J., Predey T. and Mikhael M. (1991) Neonatal asphyxia: Vulnerability of basal ganglia, thalamus and brainstem. Pediatr. Neurol. 7, 147-149.

Pellegrini-Giampietro, D.E., Cherici, G., Alesiani, M., Carla, V., and Moroni, F.(1990) Excitatory amino acid release and free radical formation may cooperate in the genesis of ischemia - induced neuronal damage. J. Neurosci. 10, 1035-1041

Radomski, M, Palmer, R. and Moncada, S. (1990) Glucocorticoids inhibit the expression of an inducible nitric oxide synthase in vascular endothelial cells. Proc. Natl. Acad Sci. USA 87, 10043-10047.

Siesjo, B.K. and Bengtsson, F.(1989) Calcium fluxes, calcium antagonist, and calcium related pathology in brain ischemia, hypoglycemia and spreading depression: A unifying hypothesis. J. Cereb. Blood Flow Metab. 9,127-140.

Williarns C.E.,Gunn A.J., Gluckenan P.D. (1991). Time course of intracellular edema and epileptiform activity following prenatal cerebral ischemia in sheep. Stroke 22, 516-521. 
Williams Chris, Mallard Carina, Tan W., and Gluckman D. P.(1984) Pathophysiology of perinatal asphyxia, in Clinics in Perinatology, vol. 20 (Editor Seetha Shankaran), pp.305-314, W. B. Saunders Company, Philadelphia.

Xie QW, Cho HJ, Calaycay J, Mumford RA, Swiderek KM, Lee TD.(1992) Cloning and characterizacion of inducible nitric oxide synthase from mouse macrophages. Science 256: $225-228$

Vincent S. and Hope B. (1992) Neurons that say NO. TINS 15, 108-113

Volpe J. (1987) Hypoxic-ischemic encephalopathy: Neuropathology and pathogenesis, In Neurology of the newborn, vol.22 (Markowitz M., de.) pp.209-235, WB Saunders, Philadhelpia 


\section{LEGEND OF FIGURES}

Fig.1 NADPH-d positive areas (shadow) in control and asphyctic newborn rats. $\mathrm{Cx}$ cerebral cortex; St: striatum; CC: corpus callosum.

Fig.2 Photomicrographs of striatal NADPH- $d(+)$ neurons in sections from (a) control, (b) severe perinatal asphyxia (PA) and (c) after $100 \mathrm{~min}$ of PA at $15^{\circ} \mathrm{C}$. Note a unipolar process in PA severe asphyctic neurons(arrows) in comparison with control and hypothermia. All cells at the same magnification. Scale bar: $10 \mathrm{pm}$

Fig. 3: Photomicrographs of cortical NADPH-d(+), neurons in sections from (a) control, (b) severe PA and (c) $100 \mathrm{~min}$ of PA at $15^{\circ} \mathrm{C}$. Note a unipolar process in a severe PA neuron (arrows) and no stained cell in control and hypothermia sections. All cells at the same magnification. Scale bar. $10 \mu \mathrm{m}$.

Fig. 4: Photomicrographs of striatal NADPHd (+) blood vessels in sections from. (a) control, (b) severe PA and (c) $100 \mathrm{~min}$ of PA at $15^{\circ} \mathrm{C}$. Note an increase in endhotelial NADPHd reactivity in severe PA compared with control and hypothermia.

Fig.5 Photomicrographs of cortical NADPHd (+) blood vessels in sections from (a) control, (b) severe PA and (c) $100 \mathrm{~min}$. of $\mathrm{PA}$ at $15^{\circ} \mathrm{C}$. Note an increase in endothelial NADPHd reactivity in severe PA, compared with control and hypothermia 
Fig. 6 Measurement of striatal NADPH-d(+) cell area (a), cell perimeter $(b)$ and Fshape (c), in rats subjected to different periods of PA at $37^{\circ} \mathrm{C}$ or $15^{\circ} \mathrm{C}$. Each value presents mean \pm SD (vertical lines) of determinations made from $n=100$ cells from each group. Statistical analysis was performed by ANOVA test. No significant differences in shape factor (c) were found for any groups inter se.

Table 1. Striatum cells counts

\begin{tabular}{|c|c|c|}
\hline Region & Asphyctic Time & Cell Number per field \\
\hline \multirow[t]{4}{*}{ Medial Striatum } & Control & $19.9 \pm 1.85$ \\
\hline & $20^{\prime} 37^{\circ}$ & $11.5 \pm 1.78$ \\
\hline & Hypothermia $20^{\prime} 15^{\circ}$ & $19.4 \pm 1.92$ \\
\hline & Hypothermia $100^{\prime} 15^{\circ}$ & $19.3 \pm 1.84$ \\
\hline \multirow[t]{4}{*}{ Dorsal Striatum } & Control & $20.2 \pm 1.92$ \\
\hline & $20^{\prime} 37^{\circ}$ & $12.2 \pm 1.96$ \\
\hline & Hypothermia $20^{\circ} 15^{\circ}$ & $19.6 \pm 1.95$ \\
\hline & Hypothermia $100^{\prime} 15^{\circ}$ & $19.5 \pm 1.87$ \\
\hline \multirow[t]{3}{*}{ Lateral Striatum } & Control & $20.4 \pm 1.95$ \\
\hline & $20^{\circ} 37^{\circ}$ & $11.4 \pm 1.87$ \\
\hline & Hypothermia $20^{\circ} \quad 15^{\circ}$ & $19.9 \pm 197$ \\
\hline
\end{tabular}


Table 2. Neocortex cells counts

\begin{tabular}{lll}
\hline Region & Asphyctic Time & Cell Number per field \\
\hline Lateral NeoCortex & Control & $25.4 \pm 1.71$ \\
& $19^{\prime} 37^{\circ}$ & $14.6 \pm 1.75$ \\
& Hypothermia 20'15 & $24.6 \pm 1.76$ \\
& Hunothermia 100'15 & $25.6 \pm 1.73$
\end{tabular}


